\title{
Towards Improving the Manure Management Chain
}

\section{Yong Hou}




\section{Thesis committee}

\section{Promotor}

Prof. Dr O. Oenema

Professor of Nutrient Management and Soil Fertility

Wageningen University

\section{Co-promotor}

Dr G.L. Velthof

Senior scientist

Wageningen University and Research, Alterra

\section{Other members}

Prof. Dr P.W.G. Groot Koerkamp, Wageningen University

Prof. Dr E. Meers, Ghent University, Belgium

Prof. Dr W. de Vries, Wageningen University

Dr T.V. Vellinga, Wageningen University and Research, Livestock Research

This research was conducted under the auspices of the C.T. de Wit Graduate School for Production Ecology and Resource Conservation 


\title{
Towards Improving the Manure Management Chain
}

\section{Yong Hou}

\author{
Thesis \\ submitted in fulfilment of the requirements for the degree of doctor \\ at Wageningen University \\ by the authority of the Rector Magnificus \\ Prof. Dr A.P.J. Mol, \\ in the presence of the \\ Thesis Committee appointed by the Academic Board \\ to be defended in public \\ on Monday 12 December 2016 \\ at 4 p.m. in the Aula.
}




\section{Y. Hou}

Towards Improving the Manure Management Chain, 215 pages.

PhD thesis, Wageningen University, Wageningen, NL (2016)

With references, with summaries in Dutch and English

DOI: $10.18174 / 392808$

ISBN: 978-94-6257-962-0 
This dissertation is dedicated to My beloved wife 



\section{Contents}

Chapter $1 \quad$ General introduction 1

Chapter 2 Nitrogen excretion factors of livestock in the European Union: a review

Chapter 3 Feed use and nitrogen excretion of livestock in EU-27

Chapter 4 Mitigation of ammonia, nitrous oxide and methane emissions from manure management chains: a meta-analysis and integrated assessment

Chapter 5 Nutrient recovery and emissions of ammonia, nitrous oxide and methane from animal manure in Europe: effects of manure treatment technologies

Chapter 6 Stakeholder perceptions of manure treatment technologies in Denmark, Italy, the Netherlands and Spain

Chapter 7 General Discussion

Summary

Samenvatting

Parts of this thesis have been published as peer-reviewed scientific articles. For this thesis, the text of the published articles or the submitted manuscript has been integrally adopted. Editorial changes were made for reasons for uniformity of presentation in this thesis. Reference should be made to the original article(s). 



\section{CHAPTER 1}

General introduction 


\section{Chapter 1}

\subsection{The need for mitigating emissions from animal manure}

The expansion of global livestock production during recent decades is driven by an increasing demand for livestock products, which follows from human population growth, income growth, urbanization and shifts in dietary preferences (Steinfeld et al., 2006; Thornton, 2010). The livestock sector becomes one of the largest current users of national resources. Livestock production systems occupy about $30 \%$ of the planet's ice-free surface, use one-third of the freshwater, and one-third of global cropland as feed (McMichael et al., 2007; Herrero et al., 2013). The growth of livestock production also leads to an increase in the production of animal manures. Animal manures contain all 14 nutrient elements that are essential for plant growth and development. Return of manure nutrients to crop land is crucial for closing the nutrient cycle. The plant nutrients in manure, if used appropriately, can replace significant amount of mineral fertilizers, and the organic matter in manure can improve soil quality and can also be used for energy production. Globally, livestock excretes 80-140 Tg nitrogen (N) and 20-30 Tg phosphorus (P) per year, which are 1-2 times the current amounts of $\mathrm{N}$ and $\mathrm{P}$ in mineral fertilizers consumed (Sheldrick et al., 2003; Potter et al., 2010).

However, improper management and utilization of manure results in nutrient losses, which may lead to negative impacts on the environment locally and globally. It has been estimated that globally only $20-40 \%$ of the $\mathrm{N}$ in animal excreta is returned to agricultural land, while the remainder is dissipated into the environment (Oenema \& Tamminga, 2005). The livestock sector is responsible for $40-65 \%$ of global anthropogenic ammonia $\left(\mathrm{NH}_{3}\right)$ emissions, $40-60 \%$ of nitrous oxide $\left(\mathrm{N}_{2} \mathrm{O}\right)$ emissions, and 30-40\% of methane $\left(\mathrm{CH}_{4}\right)$ emissions (Bouwman et al. 1997; Galloway et al., 2004; Oenema et al., 2005). The livestock sector contributes nearly $80 \%$ to the total greenhouse gas (GHG) emissions from the global agricultural sector (Steinfeld et al., 2006).

In Europe, approximately $70 \%$ of the total land area utilized for agriculture was used in 2005 for animal feed and forage production (Lesschen et al., 2011). About 60-65\% of the plant biomass consumption in Europe is associated with the livestock sector (Krausmann et al., 2008). The intensification of animal production during the $2^{\text {nd }}$ half of the $20^{\text {th }}$ century has led to high animal density in several regions of the European Union (EU) and has contributed to high nutrient surpluses regionally (Figure 1-1). These surpluses increase the risk of polluting the natural environment with nutrients (Velthof et al., 2014). The total amount of $\mathrm{N}$ in animal excreta is as large as the amount of mineral $\mathrm{N}$ fertilizer currently used in Europe. Roughly 50- 
$60 \%$ of the $\mathrm{N}$ excreted in animal housing systems is effectively returned to cropland or grassland, while the remainder is lost during storage and following the application of manure to land (Oenema et al., 2007). Animal manures are currently responsible for about $80 \%$ of the $\mathrm{NH}_{3}$ emissions, $50 \%$ of the $\mathrm{N}_{2} \mathrm{O}$ emissions, $15-25 \%$ of the $\mathrm{CH}_{4}$ emissions from agriculture in EU (Oenema et al., 2007; Leip et al., 2015).

Clearly, animal manures are large sources of nutrients and organic carbon. Because of improper storage and management, manures are also a large source of $\mathrm{NH}_{3}$ and $\mathrm{N}_{2} \mathrm{O}$ emissions into the air, and of $\mathrm{N}$ and $\mathrm{P}$ losses to water bodies. There is an urgent need to decrease nutrient losses and emissions of $\mathrm{NH}_{3}$ and GHG from animal manure management, and to increase the utilization of the nutrients in manure for feed and food production.

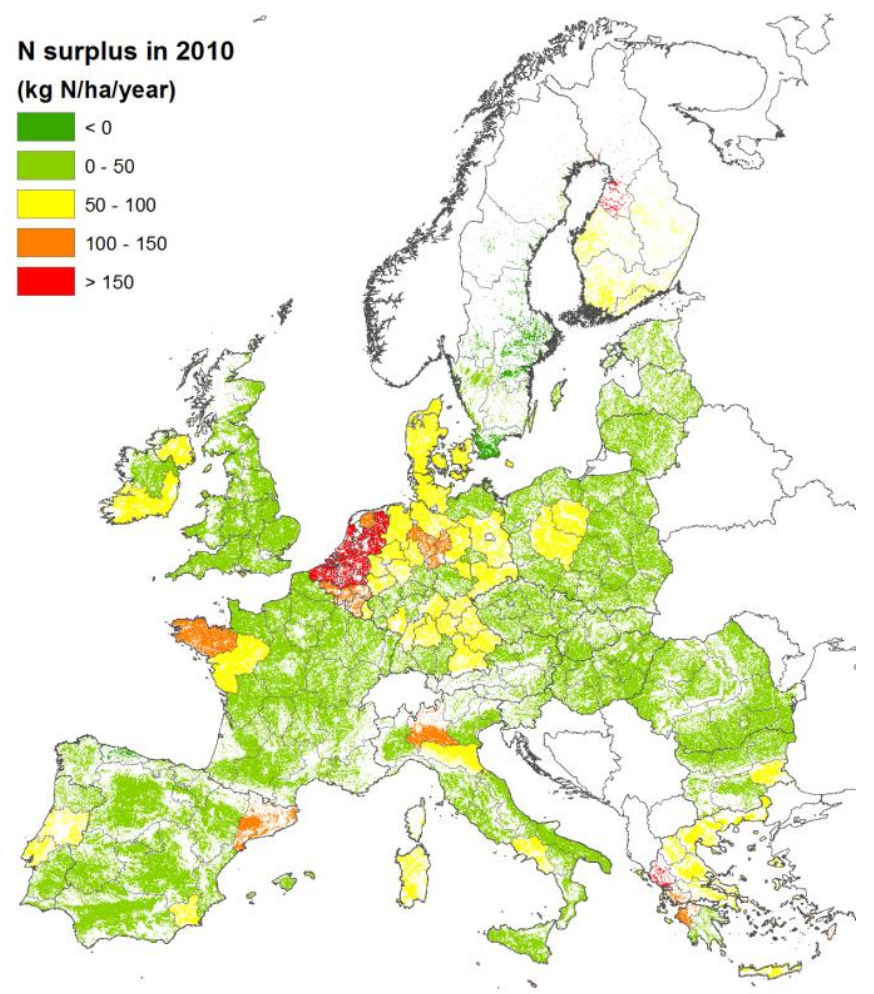

Figure 1-1. Soil nitrogen (N) surplus in the EU-27 in 2010 ( $\mathrm{kg} \mathrm{N}$ per ha of utilized agricultural area per year), based on the calculations with the MITERRA-Europe model (unpublished, Alterra). 


\subsection{Towards improved manure management}

Manure management consists of a chain of activities and technologies (Figure 1-2). The manure management chain is diverse, depending on the combination of for example animal categories, feeding strategies, grazing activities, housing structures, manure storage and treatment facilities and manure application methods.

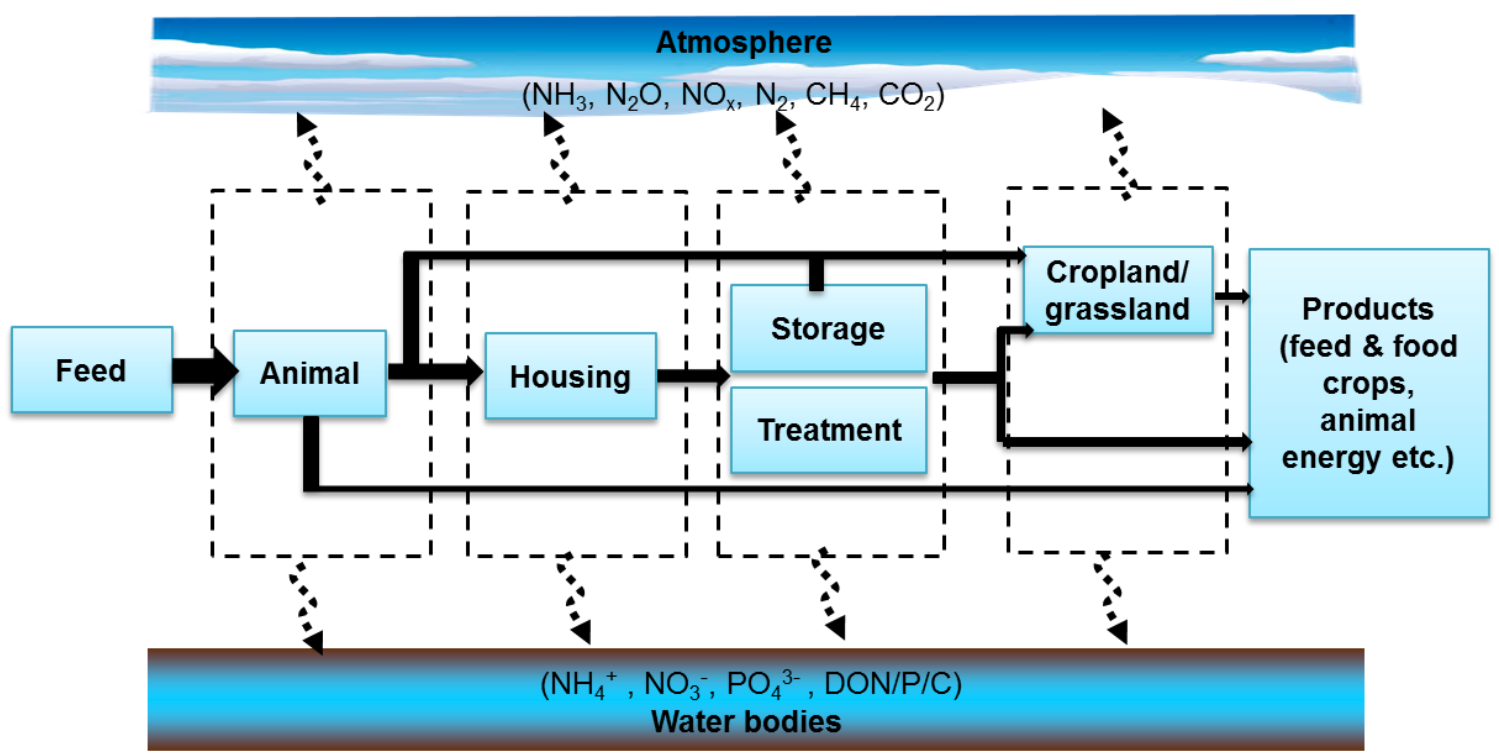

Figure 1-2. Schematic representation of the manure management chain. Solid arrows show the main flows of nutrients; dashed arrows show possible losses of nutrients to the atmosphere and to groundwater and surface waters.

A fraction of nutrients in feed are utilized by animals to produce marketed products (e.g. meat, eggs and milk); the remainder is excreted in urine and faeces. Animal excreta are generally handled in the housings as slurries (mixture of dung and urine) or solid manure (mixture of bedding material, dung and urine) with or without separate collection of liquids (mainly urine). The slurries, solid manure and liquids are often removed periodically to outdoor storages (tanks, lagoons or heaps with or without covers and leak-tight floors). After storage, the slurries, solid manure and liquids are applied to land. Urine and faeces from grazing animals are directly dropped in pastures, and are generally not collected. Nutrients in manure are partially used to fertilize cropland for feed production, thereby closing the nutrient cycle between crop and animal production systems (Oenema et al., 2007). In the whole chain from animal feeding to manure application to land, a range of measures can be taken to mitigate nutrient losses and to increase the utilization of the nutrients and organic matter contained in manures. 
Nutrient losses and emissions of $\mathrm{NH}_{3}, \mathrm{CH}_{4}$ and $\mathrm{N}_{2} \mathrm{O}$ may occur from animal manures at various management stages (Figure 1-2). Evidently, accurate estimates of the amounts of nutrients in animal manures is the starting point for estimating nutrient flows and losses in the manure management chain, and are also required for nutrient management planning (Sutton et al., 2011). The fraction of the nutrients in animal feed that ends up in manure depends on animal category, feed composition and animal productivity. International and national statistics (e.g., Eurostat and FAO statistics) provide national data on animal production and animal number per animal category annually. However, there is lack of animal categoryspecific data on feed use and composition at national levels. Such data are needed for improving the accuracy of manure production estimates.

\subsubsection{Ammonia emission mitigation measures}

Emissions of $\mathrm{NH}_{3}$ are often the largest $\mathrm{N}$ loss pathway. These emissions can contribute to the acidification and eutrophication of nitrogen-limited ecosystems (Sutton et al., 2008). Emissions of $\mathrm{NH}_{3}$ also decrease the $\mathrm{N}$ fertilizer equivalent value of animal manure. In response to the negative effects of $\mathrm{NH}_{3}$ emissions on the environment, series of policy measures have been proposed through the 1999 Gothenburg Protocol under the UN-ECE Convention on Long-Range Transboundary Air Pollution (LRTAP). This Protocol aims to abate acidification, eutrophication and ground-level ozone, and addresses also sulphur $\left(\mathrm{SO}_{2}\right)$, nitrogen oxides $\left(\mathrm{NO}_{\mathrm{x}}\right)$, and volatile organic compounds (VOCs) emissions. The $\mathrm{NH}_{3}$ emission mitigation measures of the Gothenburg Protocol have been implemented in the EU member states through the 2001/81/EC National Emission Ceiling Directive. This directive requires that Member States develop national programmes that aim at meeting agreed ceilings of national $\mathrm{NH}_{3}$ emissions by 2010 and 2020. The suggested $\mathrm{NH}_{3}$ emission mitigation measures have been described in detail in the Guidance Document for preventing and abating $\mathrm{NH}_{3}$ emissions (Bittman et al., 2014). Different $\mathrm{NH}_{3}$ emission abatement measures may target at different stages of the manure management chain, such as low-emission animal housing, covered storages and low-emission manure application (Bittman et al., 2014).

These measures typically consider $\mathrm{NH}_{3}$ emissions only, although these measures may have possible side-effects. Introducing a measure to decrease emissions at a particular stage may affect emissions downstream in the chain (e.g. pollution swapping), or emissions of other pollutants (Petersen et al., 2007; Velthof et al., 2009; Reis et al., 2015). For example, several studies have indicated that some $\mathrm{NH}_{3}$ mitigation measures may increase $\mathrm{N}_{2} \mathrm{O}$ emissions from 


\section{Chapter 1}

slurry storages or during field application, or enhance $\mathrm{CH}_{4}$ emissions from solid manures storages (e.g. Berg et al., 2006; Szanto et al., 2007; Hansen et al., 2009). These unwanted side-effects decrease the effectiveness and efficiency of mitigation measures.

A systematic quantitative analysis of the effects of $\mathrm{NH}_{3}$ mitigation measures on emissions of $\mathrm{NH}_{3}, \mathrm{~N}_{2} \mathrm{O}$ and $\mathrm{CH}_{4}$ is still lacking, especially in consideration of the whole manure management chain. The assessment of a measure or technology must include the effects of the performance of other management measures in the whole chain from animal feeding to animal excretion, in-house and outdoor manure storage, manure treatment and up to application/deposition of manure to crop land and grassland (Figure 1-2).

\subsubsection{Manure treatment}

In the EU, manure storage conditions and the maximum amount of manure to be applied per unit of agricultural area are regulated, through the 1991 EU Nitrates Directive. This Directive and the governmental incentives to replace fossil energy sources by renewable energy sources (e.g., Renewable Energy Directive-2009/28/EC) stimulate the development of manure treatment technologies, to increase the utilization of manure in terms of energy and nutrient sources, and to decrease manure surpluses in areas with high animal density (Menzi et al., 2010; Sommer et al., 2013).

A wide range of manure treatment technologies have been developed and, in part, applied in practice in EU, such as anaerobic digestion, liquid-solid separation, slurry acidification, composting, drying, and incineration (Foged et al., 2011). Different treatment technologies have different objectives, including reducing manure volumes to facilitate transport, bioenergy production, emission mitigation, improving fertilizer value of manure, increasing stability of organic matter in manure, and sanitation and odor control (see Box-1.1). Treatment technologies alter the physical, chemical and/or biological characteristics of manure, and thus may affect emissions of $\mathrm{NH}_{3}, \mathrm{~N}_{2} \mathrm{O}$ and $\mathrm{CH}_{4}$ from the manure management chain. A large number of laboratory and pilot experiments have been carried out to analyze $\mathrm{NH}_{3}$ and/or GHG emissions from processed manure. Most of these studies typically focus on a specific gas and/or emission source (i.e. manure storages or application of manure). Few studies have focused on whole-farm or life cycle effects of for example solid-liquid separation (ten Hoeve et al., 2014), anaerobic digestion (Sandars et al., 2003; Hamelin et al., 2011; De Vries et al., 2012; Mezzullo et al., 2012), and pyrolysis and incineration processes 
(Fernandez-Lopez et al., 2015). Country-scale analyses of the effects of manure treatment technologies have not been conducted yet.

Clearly, there is a lack of quantitative insights about the current and future possible effects of manure treatment technologies on nutrient and GHG emissions, and on the amount of remaining manure nutrients at various stages of the 'manure management chain', at regional and national levels. There is also lack of knowledge about optimal combinations of manure treatment technologies. Optimizing the implementation of treatment technologies requires a 'chain' approach, because of the possible interactions between measures and technologies.

\subsubsection{Stakeholder perceptions}

Implementation of manure treatment technologies in practice is still limited in most EU countries. The diffusion and exploitation of cleaner technologies rely on a combination of factors including governmental policies, financial incentives, technical and service supports and social acceptance (Montalvo, 2008). The development of manure treatment involves stakeholders across government, industry, academia, extension service and agricultural production sectors. However, there is lack of understanding about the key factors influencing the adoption of treatment technologies in practice. Identifying stimulants for and obstacles to adoption of technology is an essential step to develop effective governmental supporting programs and marketing strategies to promote the development of manure treatment. 


\section{Box 1.1 - Brief description of manure treatment technologies that are currently implemented} in Europe (Foged et al., 2011)

- Solid-liquid separation has the objective of separating manure slurry into a dry matter and nutrient -rich solid fraction and a diluted liquid fraction.

- Anaerobic digestion includes a series of biological processes in which microorganisms break down organic molecules in absence of oxygen, resulting in the production of a mixture of gases (mainly methane and carbon dioxide) that can be used as bioenergy.

- Acidification involves the application of an acidic reagent (e.g., sulfuric acid) to manure slurry to lower its $\mathrm{pH}$ to 5.5 , and thereby to reduce ammonia emissions and deactivate pathogens.

- Biological nitrogen removal (i.e. nitrification-denitrification) has the objective of biological conversion of ammonium to inert nitrogen gas $\left(\mathrm{N}_{2}\right)$ using classical nitrogen removal treatment, combining autotrophic nitrification and heterotrophic denitrification processes. The feedstock is generally the liquid fractions separated from slurry.

- Membrane (ultra) filtration targets the removal of solid particles from the separated liquid fractions in the range of 5 to $200 \mathrm{~nm}$. Reverse osmosis aims to further separate dissolved components in permeates produced by ultrafiltration (or other treatments separating small particles), by using pressure to force a solvent through a semipermeable membrane that retains the solute on one side and allows the pure solvent to pass to the other side.

- Composting includes aerobic biological decomposition and stabilization processes under conditions that allow for the development of thermophilic micro-organisms that convert the solid manure into compost. Compost is sufficiently stable for storage and subsequent soil application.

- Drying aims at reducing the moisture content and offensive odor emissions of solid manures/poultry litters by external heating, which is usually followed by pelletizing, a process of compressing a material into a smaller, denser form.

- Combustion/incineration aims to complete the thermo-chemical oxidation of organic matter in manures in order to obtain recoverable heat, ashes and gasses. For feedstocks with high moisture contents, a pre-drying process is generally required to lower moisture contents to less than $50-60 \%$ (by weight). 


\subsection{Objectives}

The first objective of the research described in this thesis is to increase the understanding of the agronomic and environmental impacts of the manure management chains in EU-27 ${ }^{1}$. The second objective is to explore options towards improving the performance of the management chain, especially related to the mitigation of $\mathrm{NH}_{3}$ and $\mathrm{GHG}\left(\mathrm{N}_{2} \mathrm{O}\right.$ and $\left.\mathrm{CH}_{4}\right)$ emissions, and to the utilization of manure $\mathrm{N}$ and $\mathrm{P}$, through application of mitigation measures and manure treatment technologies. The utilization of manure $\mathrm{N}$ and $\mathrm{P}$ depends on the fraction of the excreta $\mathrm{N}$ and $\mathrm{P}$ retained in the manure throughout the manure management chain, on its fertilizer effectiveness values, and on the judicious application of the manure to cropland or grassland. The term 'recovery of manure $\mathrm{N}$ and $\mathrm{P}$ ' has also been used to refer to the fraction of $\mathrm{N}$ and $\mathrm{P}$ excreted that ultimately returns to cropland or grassland.

This $\mathrm{PhD}$ thesis research was part of the Marie Curie Training Program ReUseWaste (Recovery and Use of Nutrients, Energy and Organic Matter from Animal Waste). In total eleven $\mathrm{PhD}$ students and two post docs have been working on various specific mitigation measures and treatment technologies (http://www.reusewaste.eu/). My research focused on the integral analysis of the whole manure management chain, and on the up-scaling and synthesis of research results, including those from literature.

The specific objectives of this thesis are to:

- Analyze the feed resource use and nutrient (especially N) excretion by animals in the EU-27 at country levels (Chapters 2 and 3)

- Assess the effects of $\mathrm{NH}_{3}$ mitigation technologies on emissions of $\mathrm{NH}_{3}, \mathrm{CH}_{4}$ and $\mathrm{N}_{2} \mathrm{O}$ from individual sources, and their whole-chain effects (Chapter 4)

- Analyze the contribution of manure treatment activities to emissions of $\mathrm{NH}_{3}, \mathrm{~N}_{2} \mathrm{O}$ and $\mathrm{CH}_{4}$ from manure management chains in EU-27 at country levels in 2010; and explore the potential whole-chain effects of these treatment technologies on emissions and nutrient recovery in the EU-27 (Chapter 5)

- Provide insights into stakeholders perceptions about factors that facilitate or hinder the adoption of treatment technology in practice (Chapter 6)

\footnotetext{
${ }^{1}$ In Chapters 3 and 5, the reference year of the analyses is 2010. Croatia is a EU member country since 2013, therefore the analyses focus on the EU-27.
} 


\section{Chapter 1}

\subsection{Outline of this thesis}

This thesis contains a general introduction (Chapter 1), five research chapters (Chapters 2-6) and a general discussion (Chapter 7).

Chapter 2 reviews $\mathrm{N}$ excretion factors of animal categories, and the guidelines and methodologies for the estimation of $\mathrm{N}$ excretion factors, as used by member states of the EU.

Chapter 3 presents a transparent and uniform methodology for estimating annual feed use and $\mathrm{N}$ excretion per animal category for all member states of the EU in 2010, based on the energy and protein requirements of the animals and statistics of feed use and composition, animal number and productivity.

Chapter 4 presents a meta-analysis of the effects of a set of $\mathrm{NH}_{3}$ mitigation measures on $\mathrm{NH}_{3}, \mathrm{CH}_{4}$ and $\mathrm{N}_{2} \mathrm{O}$ emissions from individual sources of the manure management chain, and an integrated assessment of whole-chain effects of these measures on emissions through scenario analysis.

Chapter 5 presents scenario analyses of effects of manure treatment technologies on the recovery of $\mathrm{N}$ and $\mathrm{P}$, and emissions of $\mathrm{NH}_{3}, \mathrm{~N}_{2} \mathrm{O}$ and $\mathrm{CH}_{4}$ in manure management chains in EU at country level.

Chapter 6 reports on a survey study about stakeholder perceptions of manure treatment technologies in Denmark, Italy, the Netherlands and Spain; which factors facilitate or hinder the implementation in practice of manure treatment technologies?.

Chapter 7 provides a general discussion of the main findings of the study, and identifies remaining future research needs.

Chapters 2, 3, 4, 6 have been published in peer-reviewed journals. Chapter 5 is accepted subject to revision. 


\section{References}

Berg W, Brunsch R, Pazsiczki I (2006) Greenhouse gas emissions from covered slurry compared with uncovered during storage. Agriculture, Ecosystems \& Environment, 112, 129-134.

Bittman S, Dedina M, Howard C, Oenema O, Sutton M (2014) Options for Ammonia Mitigation: Guidance from the UNECE Task Force on Reactive Nitrogen. Centre for Ecology and Hydrology, Edinburgh, UK.

Bouwman AF, Lee DS, Asman WAH, Dentener FJ, Van Der Hoek KW, Olivier JGJ (1997) A global high-resolution emission inventory for ammonia. Global Biogeochemical Cycles, 11, 561-587.

De Vries JW, Vinken TMWJ, Hamelin L, De Boer IJM (2012) Comparing environmental consequences of anaerobic mono- and co-digestion of pig manure to produce bio-energy--a life cycle perspective. Bioresource technology, 125, 239-48.

Fernandez-Lopez M, Puig-Gamero M, Lopez-Gonzalez D, Avalos-Ramirez A, Valverde J, SanchezSilva L (2015) Life cycle assessment of swine and dairy manure: Pyrolysis and combustion processes. Bioresource Technology, 182, 184-192.

Foged HL, Flotats X, Blasi AB, Palatsi J, Magri A, Schelde KM (2011) Inventory of manure processing activities in Europe. Technical Report No. I concerning "Manure Processing Activities in Europe" to the European Commission, Directorate-General Environment. 138 pp.

Galloway JN, Dentener FJ, Capone DG et al. (2004) Nitrogen Cycles: Past, Present, and Future. Biogeochemistry, 70, 153-226.

Hamelin L, Wesnæs M, Wenzel H, Petersen BM (2011) Environmental consequences of future biogas technologies based on separated slurry. Environmental science \& technology, 45, 5869-77.

Hansen RR, Nielsen DA, Schramm A, Nielsen LP, Revsbech NP, Hansen MN (2009) Greenhouse gas microbiology in wet and dry straw crust covering pig slurry. Journal of environmental quality, 38, 1311-9.

Herrero M, Havlík P, Valin H et al. (2013) Biomass use, production, feed efficiencies, and greenhouse gas emissions from global livestock systems. Proceedings of the National Academy of Sciences of the United States of America, 110, 20888-93.

Krausmann F, Erb K-H, Gingrich S, Lauk C, Haberl H (2008) Global patterns of socioeconomic biomass flows in the year 2000: A comprehensive assessment of supply, consumption and constraints. Ecological Economics, 65, 471-487.

Leip A, Billen G, Garnier J et al. (2015) Impacts of European livestock production: nitrogen, sulphur, phosphorus and greenhouse gas emissions, land-use, water eutrophication and biodiversity. Environmental Research Letters, 10, 115004.

Lesschen JP, van den Berg M, Westhoek HJ, Witzke HP, Oenema O (2011) Greenhouse gas emission profiles of European livestock sectors. Animal Feed Science and Technology, 166-167, 16-28.

McMichael AJ, Powles JW, Butler CD, Uauy R (2007) Food, livestock production, energy, climate change, and health. Lancet, 370, 1253-1263.

Menzi H, Oenema O, Burton C (2010) Impacts of intensive livestock production and manure management on the environment. In: Livestock in a changing landscape, drivers, consequences, and responses (ed Steinfeld, H., Mooney, H.A., Schneider, F., Neville LE), pp. 139-164. Island Press.

Mezzullo WG, McManus MC, Hammond GP (2012) Life cycle assessment of a small-scale anaerobic digestion plant from cattle waste. Applied Energy, 102, 657-664.

Montalvo C (2008) General wisdom concerning the factors affecting the adoption of cleaner technologies: a survey 1990-2007. Journal of Cleaner Production, 16, 7-13.

Oenema O, Tamminga S (2005) Nitrogen in global animal production and management options for improving nitrogen use efficiency. Science in China Series C: Life Sciences, 48, 871-887. 


\section{Chapter 1}

Oenema O, Wrage N, Velthof GL, Groenigen JW, Dolfing J, Kuikman PJ (2005) Trends in Global Nitrous Oxide Emissions from Animal Production Systems. Nutrient Cycling in Agroecosystems, $72,51-65$.

Oenema O, Oudendag D, Velthof GL (2007) Nutrient losses from manure management in the European Union. Livestock Science, 112, 261-272.

Petersen S, Sommer S, Beline F et al. (2007) Recycling of livestock manure in a whole-farm perspective. Livestock Science, 112, 180-191.

Potter P, Ramankutty N, Bennett EM, Donner SD (2010) Characterizing the spatial patterns of global fertilizer application and manure production. Earth Interactions, 14.

Reis S, Howard C, Sutton MA (2015) Costs of Ammonia Abatement and the Climate Co-Benefits (eds Reis S, Howard C, Sutton MA). Springer Netherlands, Dordrecht, 292 pp.

Sandars DL, Audsley E, Cañete C, Cumby TR, Scotford IM, Williams a. G (2003) Environmental Benefits of Livestock Manure Management Practices and Technology by Life Cycle Assessment. Biosystems Engineering, 84, 267-281.

Sheldrick W, Keith Syers J, Lingard J (2003) Contribution of livestock excreta to nutrient balances. Nutrient Cycling in Agroecosystems, 66, 119-131.

Sommer SG, Christensen ML, Schmidt T, Jensen LS (2013) Animal Manure Recycling: Treatment and Management. $382 \mathrm{pp}$.

Steinfeld H, Gerber P, Wassenaar T, Castel V, Roslaes M, De Haan C (2006) Livestock's long shadow. environmental issues and options. FAO report, Rome, Italy. 390 pp.

Sutton M, Howard C, Erisman J (2011) The European nitrogen assessment: sources, effects and policy perspectives. $612 \mathrm{pp}$.

Szanto GL, Hamelers HVM, Rulkens WH, Veeken AHM (2007) NH3, N2O and CH4 emissions during passively aerated composting of straw-rich pig manure. Bioresource technology, 98, 2659-2670.

ten Hoeve M, Hutchings NJ, Peters GM, Svanström M, Jensen LS, Bruun S (2014) Life cycle assessment of pig slurry treatment technologies for nutrient redistribution in Denmark. Journal of environmental management, 132, 60-70.

Thornton PK (2010) Livestock production: recent trends, future prospects. Philosophical transactions of the Royal Society of London. Series B, Biological sciences, 365, 2853-2867.

Velthof GL, Oudendag D, Witzke HP, Asman W a H, Klimont Z, Oenema O (2009) Integrated assessment of nitrogen losses from agriculture in EU-27 using MITERRA-EUROPE. Journal of environmental quality, 38, 402-417.

Velthof GL, Lesschen JP, Webb J et al. (2014) The impact of the Nitrates Directive on nitrogen emissions from agriculture in the EU-27 during 2000-2008. The Science of the total environment, $468-469,1225-1233$. 


\section{CHAPTER 2}

\section{Nitrogen excretion factors of livestock in the \\ European Union: a review}




\title{
Chapter 2
}

\begin{abstract}
Livestock manures are major sources of nutrients, used for the fertilization of cropland and grassland. Accurate estimates of the amounts of nutrients in livestock manures are required for nutrient management planning, but also for estimating nitrogen $(\mathrm{N})$ budgets and emissions to the environment. Here we report on $\mathrm{N}$ excretion factors for a range of animal categories in policy reports by member states of the European Union (EU). Nitrogen excretion is defined in this paper as the total amount of $\mathrm{N}$ excreted by livestock per year as urine and faeces. We discuss the guidelines and methodologies for the estimation of $\mathrm{N}$ excretion factors by the EU Nitrates Directive, the OECD/Eurostat gross $\mathrm{N}$ balance guidebook, the EMEP/EEA Guidebook and the IPCC Guidelines. Our results show that N excretion factors for dairy cattle, other cattle, pigs, laying hens, broilers, sheep, and goats differ significantly between policy reports and between countries. Part of these differences may be related to differences in animal production (e.g. production of meat, milk and eggs), size/weight of the animals, and feed composition, but partly also to differences in the aggregation of livestock categories and estimation procedures. The methodologies and data used by member states are often not well described. There is a need for a common, harmonized methodology and procedure for the estimation of $\mathrm{N}$ excretion factors, to arrive at a common basis for the estimation of the production of manure $\mathrm{N}$ and $\mathrm{N}$ balances, and emissions of ammonia $\left(\mathrm{NH}_{3}\right)$ and nitrous oxide $\left(\mathrm{N}_{2} \mathrm{O}\right)$ across the EU.
\end{abstract}




\subsection{Introduction}

Livestock manures are major sources of nutrients, to be used for the fertilization of cropland and grassland. Accurate estimates of the amounts of nutrients in livestock manures are required for nutrient management planning, but also for estimating nitrogen $(\mathrm{N})$ budgets and emissions of $\mathrm{N}$ to the environment (Sutton et al., 2011). Nitrogen excretion is defined in this paper as the total amount of $\mathrm{N}$ excreted by livestock per year as urine and faeces. The total amount of $\mathrm{N}$ excreted as manure by livestock in the member states of the European Union (EU) was $9.2 \mathrm{Tg}$ in 2011, which is only $15 \%$ less than the amount of $10.6 \mathrm{Tg}$ artificial fertilizer $\mathrm{N}$ consumed (Source: Eurostat statistics). The $\mathrm{N}$ in manure is vulnerable to losses via emissions of ammonia $\left(\mathrm{NH}_{3}\right)$, nitrous oxide $\left(\mathrm{N}_{2} \mathrm{O}\right)$ and nitrogen oxides $\left(\mathrm{NO}_{\mathrm{x}}\right)$ to the atmosphere and via leaching of nitrate $\left(\mathrm{NO}_{3}{ }^{-}\right)$, ammonium $\left(\mathrm{NH}_{4}{ }^{+}\right)$and organic $\mathrm{N}$ to groundwater and surface waters. Emissions of $\mathrm{NH}_{3}$ occur from manure $\mathrm{N}$ in animal houses, manure storages, and following the application of manure to soils, including the droppings from grazing animals in pastures (Webb et al., 2013). Deposition of atmospheric $\mathrm{NH}_{3}$ to land and surface waters results in eutrophication of ecosystems, acidification and loss of biodiversity. Moreover, $\mathrm{NH}_{3}$ may form fine particles (PM) in the atmosphere, which negatively affect human health (Moldanová et al., 2011). The nitrification and denitrification of $\mathrm{N}$ from manure may release nitrous oxide $\left(\mathrm{N}_{2} \mathrm{O}\right)$, nitrogen oxide $\left(\mathrm{NO}_{\mathrm{x}}\right)$ and dinitrogen $\left(\mathrm{N}_{2}\right)$ into the atmosphere. Gaseous $\mathrm{N}$ emissions occur from manure applied to land, deposition of excreta by grazing animals, and from animal houses and manure storages. Nitrous oxide is a potent greenhouse gas and is an important cause for depletion of stratospheric ozone (Ravishankara et al., 2009; IPCC, 2014). Nitrogen oxides can react with carbon monoxide and volatile organic compounds in air, resulting in the formation of tropospheric or ground level ozone $\left(\mathrm{O}_{3}\right)$. Ground-level $\mathrm{O}_{3}$ pollution has several negative effects on health (Moldanová et al., 2011). Dinitrogen is harmless for the environment, but $\mathrm{N}_{2}$ losses like other $\mathrm{N}$ loss pathways decrease the $\mathrm{N}$ use efficiency of agricultural systems and, by that, increases the need for $\mathrm{N}$ fertilizers. Application of manure and droppings of grazing animals may also result in $\mathrm{N}$ leaching to groundwater and surface waters, which subsequently may cause eutrophication of surface water and pollution of groundwater as drinking water (Camargo and Alonso, 2006; WHO, 2011).

Several policies have been implemented by the European Union (EU) and United Nations (UN) bodies to improve the utilization of manure nutrients in agriculture and to decrease $\mathrm{N}$ 


\section{Chapter 2}

emissions to the environment (Oenema et al., 2011). These policies include the EU National Emission Ceiling Directive (European Commission, 2001) and the Gothenborg protocol of the UN-ECE Convention on Long-range Transboundary Air Pollution (UNECE, 1999) to decrease $\mathrm{NH}_{3}$ and $\mathrm{NO}_{\mathrm{x}}$ emissions, the UN-FCCC Kyoto protocol to decrease $\mathrm{N}_{2} \mathrm{O}$ emission (UNFCCC, 1997), and the EU Nitrates Directive to decrease N leaching to groundwater and surface waters (European Commission, 1991). In addition, OECD and Eurostat developed agri-environmental indicators for monitoring of the pressures by agriculture on the environment and of the state of the environment (European Commission, 2006; OECD, 2013).

Evidently, there is a need for accurate estimates of $\mathrm{N}$ excretion by livestock, to be able to calculate and monitor manure production, $\mathrm{N}$ balances of agriculture and emissions of $\mathrm{N}$ to the environment. Currently, there are no uniform, standard and accepted methodologies and terminologies for estimating the amounts of $\mathrm{N}$ and $\mathrm{P}$ in animal excrements. Guidelines and recommended methodologies for the estimation of $\mathrm{N}$ excretion and associated emissions of $\mathrm{NH}_{3}$ and $\mathrm{NO}_{\mathrm{x}}\left(\right.$ EEA, 2013) and $\mathrm{N}_{2} \mathrm{O}$ (IPCC, 2006) are given by the Gothenborg protocol and Kyoto protocol, respectively. The EU Nitrates Directive includes a maximum manure application standard of $170 \mathrm{~kg} \mathrm{~N}$ per ha, to be applied in so-called nitrate vulnerable zones. Guidelines to calculate manure $\mathrm{N}$ application rates are available (Ketelaars and Van der Meer, 1999). The OECD and Eurostat give also recommendations for the calculation of $\mathrm{N}$ excretion, as part of the gross $\mathrm{N}$ balance indicator (OECD/Eurostat, 2007).

Further, EU policies are evaluated or underpinned using integrated assessment models such as GAINS (http://gains.iiasa.ac.at/models/) and CAPRI (www.capri-model.org). GAINS is used for emission projections of greenhouse gases and atmospheric pollutants, including $\mathrm{NH}_{3}$. CAPRI is an economic model used for exploring reforms of for example the Common Agricultural Policies (CAP) and biofuel policies. CAPRI includes a module for the calculation of $\mathrm{N}$ balances and greenhouse gas emissions. GAINS (Klimont and Brink, 2004) and CAPRI (Leip et al., 2010) both use methodologies for the estimation $\mathrm{N}$ excretion by livestock.

EU member States tend to use methods to estimate excretion which they have developed and improved over time, and sometimes use different methodologies for different reporting requirements (Oenema et al., 2011). This make comparisons between countries and estimates at EU level complicated. 
Here, we present a review of the methodologies for the calculation of $\mathrm{N}$ excretion factors in $\mathrm{EU}$, and provide a comparison of the $\mathrm{N}$ excretion factors used for different policy streams and models by the EU member states. First, we present a review of the used methodologies. Thereafter, the reported $\mathrm{N}$ excretion factors for different livestock categories and EU member states are summarized and discussed. Finally, we present recommendations for a common, harmonized methodology for estimating $\mathrm{N}$ excretion factors.

\subsection{Review of methods to estimate nitrogen excretion factors}

\subsubsection{Type of methods}

The most common method for deriving $\mathrm{N}$ excretion factors is the input-output balance of the animal, which assumes that the amount of $\mathrm{N}$ excreted in faeces and urine is equal to the total amount of feed $\mathrm{N}$ consumed minus the $\mathrm{N}$ retained in marketed products (milk, meat, eggs, live weight gain). Hence, $\mathrm{N}$ excretion $=\mathrm{N}$ intake $-\mathrm{N}$ retention.

Two approaches are used for the estimation of $\mathrm{N}$ excretion factors, i.e. the gross and net $\mathrm{N}$ excretion. The gross $\mathrm{N}$ excretion is the total $\mathrm{N}$ excretion in urine and faeces from an animal without accounting for any $\mathrm{N}$ loss after excretion. The net $\mathrm{N}$ excretion is defined as the total amount of manure $\mathrm{N}$ (mixture of collected urine and faeces) that is applied to land, i.e. the net $\mathrm{N}$ excretion is defined as the gross $\mathrm{N}$ excretion corrected for $\mathrm{N}$ losses from housing systems and manure storages. The amount of $\mathrm{N}$ consumed by the animal depends on the feed intake by the animal, and the $\mathrm{N}$ content of the feed. Total feed intake depends on the maintenance cost and production level of the animal (e.g. growth rate, milk and egg production), and the feeding value and digestibility of the feed. Data on the annual $\mathrm{N}$ retention in meat, egg, milk, or wool produced is usually derived from production statistics and scientific reports about the $\mathrm{N}$ contents in animal products. The IPCC guidelines present default values of $\mathrm{N}$ retention (IPCC, 2006). More details about the gross $\mathrm{N}$ excretion methods are provided in the following sections.

The net excretion can be calculated from i) the gross $\mathrm{N}$ excretion corrected for gaseous $\mathrm{N}$ emissions (as $\mathrm{NH}_{3}, \mathrm{~N}_{2} \mathrm{O}, \mathrm{N}_{2}$, and $\mathrm{NOx}$ ) from housing systems and manure storages, or ii) from the volume or mass and the $\mathrm{N}$ content of the manure in the manure storage just before application to land. Estimates for gaseous $\mathrm{N}$ losses from housing systems and manure storages can be based on the default emission factors in the guidelines for $\mathrm{NH}_{3}(\mathrm{EEA}, 2013)$ and $\mathrm{N}_{2} \mathrm{O}$ 


\section{Chapter 2}

emissions (IPCC, 2006). Some countries have derived country specific emission factors, taking county specific housing systems and conditions into account, e.g. Denmark (Hutchings et al., 2001), France (Gac et al., 2007), Ireland (Hyde et al., 2003), Germany (Dämmgen et al., 2006), The Netherlands (Velthof et al., 2012), and UK (Webb and Misselbrook, 2004).

For the second approach, the volume or mass and the $\mathrm{N}$ content of produced manure have to be estimated. Estimating the mass or volume and $\mathrm{N}$ content of manures in storages is not without discussion. One option is to use default factors for manure excretion per animal and to correct for changes in volume through for example water entering manure storages (rain, spilling and cleaning water), additions of bedding materials like straw and dust, evaporation of water and compaction processes. The volume or mass can also be estimated by measurement of the dimension of the manure storage or tanker or by weighing. For translation of the volume in mass and vice versa, manure density factors are needed. The $\mathrm{N}$ content of manures are either measured or based on defaults. Manures are often very heterogeneous, and the variation in $\mathrm{N}$ contents is very large. As a consequence, a large number of samples is needed to obtain an accurate average $\mathrm{N}$ content, using well-designed sampling protocols. In the Netherlands, all transports of manure have to be sampled and analyzed on $\mathrm{N}$ and $\mathrm{P}$ contents because of legislation. The results show large variations in $\mathrm{N}$ contents between livestock categories and within a livestock category (Table 2-1). The variation within a livestock category is largest for solid manure. For most manures the variation is larger for $\mathrm{P}$ than for $\mathrm{N}$. The large variation of $\mathrm{N}$ and $\mathrm{P}$ contents in solid manure is due to the heterogeneous distribution of nutrients in these manures, and also due to the diversity in solid management systems. Nicholson et al. (1996) also found large variations in the composition of solid poultry manures in England and Wales.

The calculation of gross and net $\mathrm{N}$ excretion factors is reported on different spatial scales. Generally, $\mathrm{NH}_{3}$ and $\mathrm{N}_{2} \mathrm{O}$ emissions are reported on a national level for the Gothenborg and Kyoto protocols, nutrient balances at regional to national level for the OECD/Eurostat reports, and the manure production at farm level for the Nitrates Directive. 
Nitrogen excretion factors of livestock: a review

Table 2-1. Average and standard deviation (SD) of $\mathrm{N}$ and $\mathrm{P}$ (expressed in $\mathrm{P}_{2} \mathrm{O}_{5}$ ) contents of livestock manure in the Netherlands (Van Bruggen, 2014), based on data of 2011-2013 of the Dutch Ministry of Economic Affairs.

\begin{tabular}{|c|c|c|c|c|c|c|}
\hline \multicolumn{2}{|c|}{ Animal and manure type } & \multirow{3}{*}{$\begin{array}{r}\text { No of samples } \\
10436\end{array}$} & \multirow{2}{*}{$\frac{\mathrm{N}\left(\mathrm{g} \mathrm{kg}^{-1} \text { manure }\right)}{\text { Average }}$} & \multicolumn{3}{|c|}{$\mathrm{P}_{2} \mathrm{O}_{5}\left(\mathrm{~g} \mathrm{~kg}^{-1}\right.$ manure $)$} \\
\hline & & & & SD & Average & SD \\
\hline \multirow[t]{5}{*}{ Cattle } & Solid cow manure & & 7.7 & 5.7 & 4.3 & 5.2 \\
\hline & Liquid fraction separated cow slurry & 1136 & 4.5 & 2.1 & 1.8 & 0.8 \\
\hline & Cow slurry & 201087 & 4.0 & 0.7 & 1.5 & 0.4 \\
\hline & Calve (white meat) slurry & 46526 & 3.1 & 1.0 & 1.4 & 1.1 \\
\hline & Calve (red meat) slurry & 24216 & 5.6 & 1.7 & 2.3 & 0.8 \\
\hline \multirow[t]{7}{*}{ Poultry } & Chicken slurry & 602 & 10.0 & 3.2 & 6.0 & 2.5 \\
\hline & Chicken manure (manure belt) & 9477 & 28.4 & 9.9 & 23.0 & 10.5 \\
\hline & Chicken dried manure (manure belt) & 9149 & 32.7 & 9.4 & 25.9 & 8.9 \\
\hline & Chicken litter & 29107 & 29.0 & 8.6 & 25.6 & 8.0 \\
\hline & Broiler & 27266 & 34.1 & 6.7 & 16.6 & 5.8 \\
\hline & Turkey & 2053 & 32.7 & 8.7 & 22.5 & 5.9 \\
\hline & Duck & 1268 & 10.7 & 6.6 & 9.7 & 6.5 \\
\hline \multirow[t]{4}{*}{ Pigs } & Solid pig manure & 3895 & 13.9 & 14 & 13.6 & 13.5 \\
\hline & Liquid fraction separated pig slurry & 17672 & 1.9 & 1.8 & 0.8 & 0.8 \\
\hline & Sow slurry & 70598 & 3.8 & 1.7 & 2.5 & 1.8 \\
\hline & Fattening pig slurry & 118616 & 7.0 & 1.9 & 3.9 & 1.5 \\
\hline Sheep & & 256 & 8.7 & 2.7 & 5.1 & 2.4 \\
\hline Goat & & 11135 & 9.7 & 10.1 & 5.4 & 7.2 \\
\hline Horses & & 2585 & 5.6 & 2.4 & 3.0 & 1.5 \\
\hline Rabbits & & 964 & 13.6 & 5.4 & 12.6 & 5.1 \\
\hline
\end{tabular}




\section{Chapter 2}

\subsubsection{Methodologies in the IPCC guidelines}

Countries have to report annually greenhouse gas emissions to the UNFCCC; the National Greenhouse Gas Inventories (NIR). The method used to calculate greenhouse gas emissions is based on the IPCC guidelines. The IPCC Guidelines include recommendations for NIR. These guidelines also include recommendations for the calculation of $\mathrm{N}$ excretion factors, to be able to calculate direct and indirect $\mathrm{N}_{2} \mathrm{O}$ emissions, and thereby $\mathrm{NH}_{3}$ emissions and $\mathrm{NO}_{3}$ (nitrate) leaching. Losses of $\mathrm{NH}_{3}$ and $\mathrm{NO}_{3}$ are indirect sources of $\mathrm{N}_{2} \mathrm{O}$ emissions. The IPCC Guidelines contain recommendations at different levels of detail, i.e. the Tier levels. The Tier 1 approach is the most simple method and includes default estimates of $\mathrm{N}$ excretion. The Tier 2 and 3 approaches are more detailed and include country specific estimates and/or models. Nitrogen excretion factors have be determined for each livestock category.

The Tier 1 excretion factors are expressed in ${\mathrm{kg} \mathrm{N} 1000 \mathrm{~kg}^{-1} \text { animal day }}^{-1}$. These rates can be applied to livestock sub-categories of varying ages and growth stages using a typical average animal mass (TAM) for that population sub-category. The IPCC Guidelines include default TAM coefficients, but it is recommended to use country-specific TAM factors.

For Tier 2, the annual $\mathrm{N}$ excretion is calculated from the $\mathrm{N}$ intake and $\mathrm{N}$ retention data as $\operatorname{Nex}(\mathrm{T})=\operatorname{Nintake}(\mathrm{T}) *[1-\operatorname{Nretention}(\mathrm{T})]$, where $\operatorname{Nex}(\mathrm{T})$ is the annual $\mathrm{N}$ excretion rate of animal of species/category $\mathrm{T}\left(\mathrm{kg} \mathrm{N}_{\text {animal }}{ }^{-1}\right.$ year $\left.^{-1}\right)$, Nintake $(\mathrm{T})$ is the annual $\mathrm{N}$ intake per head of animal of species/category $\mathrm{T}$ ( $\mathrm{kg} \mathrm{N}$ per animal per year), and Nretention( $\mathrm{T}$ ) is the dimensionless fraction of annual $\mathrm{N}$ intake that is retained by animal of species/category $\mathrm{T}$. Default $\mathrm{N}$ retention fractions are provided in the IPCC Guidelines: 0.20 for dairy cows, 0.07 for other cows, 0.30 for pigs and poultry, 0.10 for sheep and goats, and 0.07 for horses. The IPCC guidelines recommend the use of country specific $\mathrm{N}$ intake and retention data for each livestock category, which should be based on national data statistics and information from animal nutrition specialists.

For Tier 3, country-specific methods and models are being used. These methods and models should be well documented and reviewed, and should clearly describe the estimation procedures.

Our analyses of the national inventory reports for 2011 show that most Member States use a country specific approach for $\mathrm{N}$ excretion estimates (Table 2-2). Some member states use a 
country specific approach for the main livestock categories and the IPCC default values for the other categories.

\subsubsection{Methodologies in the EMEP/EEA inventory guidebook}

The EMEP/EEA air pollutant emission inventory guidebook provides guidance on estimating emissions from both anthropogenic and natural sources of gaseous pollutants, including $\mathrm{NH}_{3}$ (EEA, 2013) The Tier 1 approach for $\mathrm{NH}_{3}$ emissions in this guidebook is not based on $\mathrm{N}$ excretion factor. It includes default $\mathrm{NH}_{3}$ emission factors in $\mathrm{kg} \mathrm{NH}_{3}$ animal ${ }^{-1}$.

The Tier 2 and Tier 3 are based on emission factors, which relate excreted total $\mathrm{N}$ or excreted total ammoniacal nitrogen (TAN) to $\mathrm{NH}_{3}$ emissions. The Tier 2 approach is based on default $\mathrm{N}$ excretion factors and comparable to the IPCC Tier 1. For Tier 3 country-specific models and country specific data are required. There is no restriction on the form of Tier 3, provided it can be demonstrated that the estimated emissions with Tier 3 are more accurate than those with Tier 2. If data are available, emission calculations may be made for a larger number of livestock categories than listed under Tier 2. Generally, standard values for TAN, per animal category, are used to calculate the TAN excretion (Reidy et al., 2008). Default values for the fraction of TAN in total $\mathrm{N}$ range from $0.5-0.7$ (EEA, 2013). In the Netherlands, TAN values are calculated annually on the basis of data statistics about feed composition (Velthof et al., 2012).

Our analyses of national inventory reports for the Gothenborg protocol shows that 11 countries use a Tier 1 methodology (not based on $\mathrm{N}$ excretion factors), and the other use (combinations of) Tier 2 excretion factors and country specific excretion factors (Table 2-2). 


\section{Chapter 2}

Table 2-2. Sources/methods of nitrogen excretion used in the National Inventory Reports of UNFCCC (NIR), reports for Gothenborg protocol and action programmes of the Nitrates Directive.

\begin{tabular}{|c|c|c|c|}
\hline Country & NIR & Gothenborg protocol & Nitrates Directive \\
\hline Austria & $\mathrm{N}^{2}$ balance $^{\mathrm{a}}$ & As NIR & Country specific net excretion \\
\hline Belgium & Country specific & As NIR & As NIR for Flanders. Gross excretion for Walloon \\
\hline Bulgaria & IPPC default & Tier $1-\mathrm{NH}_{3}$ based $^{\mathrm{b}}$ & $\mathrm{N}$ content and volume of manure ${ }^{\mathrm{c}}$ \\
\hline Cyprus & IPPC default & Tier $1-\mathrm{NH}_{3}$ based & $\mathrm{N}$ content and volume of manure \\
\hline Czech Rep. & IPPC default & Not clear & $\mathrm{N}$ content and volume of manure \\
\hline Denmark & $\mathrm{N}$ balance & $\mathrm{N}$ balance & As NIR; corrected for gaseous $\mathrm{N}$ loss \\
\hline Estonia & IPPC default, except dairy cow & Tier $1-\mathrm{NH}_{3}$ based & $\mathrm{N}$ content and volume of manure \\
\hline Finland & $\mathrm{N}$ balance & As NIR & $\mathrm{N}$ balance \\
\hline France & IPPC default & Tier $1-\mathrm{NH}_{3}$ based & $\mathrm{N}$ balance; corrected for gaseous $\mathrm{N}$ loss \\
\hline Germany & Region specific $\mathrm{N}$ balance & As NIR & Country specific gross excretion. Method not indicated \\
\hline Greece & IPPC default & Not indicated & $\mathrm{N}$ content and volume of manure \\
\hline Hungary & IPPC default & Tier $1-\mathrm{NH}_{3}$ based & Country specific net excretion, based on literature \\
\hline Ireland & $\mathrm{N}$ balance & Tier $1-\mathrm{NH}_{3}$ based & As NIR \\
\hline Italy & $\mathrm{N}$ balance & As NIR & As NIR \\
\hline Latvia & $\mathrm{N}$ balance & Tier $1-\mathrm{NH}_{3}$ based & $\mathrm{N}$ content and volume of manure \\
\hline Lithuania & $\mathrm{N}$ balance for cattle and pigs. Other default IPCC & Tier $1-\mathrm{NH}_{3}$ based & Net excretion based on $\mathrm{N}$ balance and gaseous $\mathrm{N}$ loss \\
\hline Luxembourg & Country specific; method not indicated & Tier $1-\mathrm{NH}_{3}$ based & Not indicated \\
\hline Malta & Country specific; method not indicated & Not indicated & Not indicated \\
\hline Netherlands & $\mathrm{N}$ balance & As NIR & As NIR \\
\hline Poland & Country specific for dairy cattle, pigs, and horses & Country specific & $\mathrm{N}$ content and volume of manure \\
\hline Portugal & Country specific & As NIR & $\mathrm{N}$ content and volume of manure \\
\hline Romania & IPPC default & Tier $1-\mathrm{NH}_{3}$ based & As NIR \\
\hline Slovakia & IPPC default & Tier $1-\mathrm{NH}_{3}$ based & $\mathrm{N}$ content and volume of manure \\
\hline Slovenia & Dairy cattle based on milk production & As NIR & Country specific net excretion. Method not indicated. \\
\hline Spain & $\mathrm{N}$ balance & As NIR & Country specific gross excretion. Method not indicated. \\
\hline Sweden & Country specific model & Country specific model & Country specific model \\
\hline UK & $\mathrm{N}$ balance & As NIR & As NIR \\
\hline
\end{tabular}

${ }^{\mathrm{a}}$ Input - output balance of the animal

${ }^{\mathrm{b}}$ Emission of $\mathrm{NH}_{3}$ is expressed in $\mathrm{kg} \mathrm{NH}_{3}$ per animal; $\mathrm{N}$ excretion is not used in Tier 1 approach

${ }^{\mathrm{c}}$ The manure production/ $\mathrm{N}$ excretion calculated from volume of manure and the $\mathrm{N}$ content of the manure 


\subsubsection{Methodologies for the EU Nitrates Directive}

The EU Nitrates Directive has the objective to decrease nitrate leaching to groundwater and surface waters. One of the measures in the Nitrates Directive is a maximum application standard of manure of $170 \mathrm{~kg} \mathrm{~N}$ per ha per year. Farmers have to calculate the amount of manure $\mathrm{N}$ that is produced on their farm and that can be applied to land. Member States of the EU have to report $\mathrm{N}$ excretion values in their Nitrates Directive Action Programmes for socalled Nitrate Vulnerable Zones. Our analyses indicate that the approaches for the calculation of the $\mathrm{N}$ excretion per livestock category differ between the Member States (Table 2-2). Many countries use a feed balance method to calculate $\mathrm{N}$ excretion for a large number of animal categories, but some countries use default estimates of $\mathrm{N}$ excretion, and others use a method based on estimating the volume or mass of manure and the $\mathrm{N}$ content of the manure.

The 1999 study "Establishment of criteria for the assessment of the nitrogen content of animal manures" presents guidelines for the calculation of manure $\mathrm{N}$ production, to be used within the framework of the EU Nitrates Directive (Ketelaars and Van der Meer, 1999). The manure $\mathrm{N}$ production is calculated as: Nmanure $=$ Ndiet - Nanimal products - Nlosses from buildings and manure storage, where Nmanure is the manure production in $\mathrm{kg} \mathrm{N}_{\text {animal }}{ }^{-1}$ year $^{-1}$, Ndiet is the feed $\mathrm{N}$ consumed in $\mathrm{kg} \mathrm{N}_{\text {animal }}{ }^{-1}$ year $^{-1}$, Nanimal products is $\mathrm{N}$ retention $(\mathrm{N}$ in animal products) in $\mathrm{kg} \mathrm{N}_{\text {animal }}{ }^{-1}$ year ${ }^{-1}$, and Nlosses from buildings and manure storage are the gaseous $\mathrm{N}$ losses in animal housings and manure storages, in $\mathrm{kg} \mathrm{N}$ animal $^{-1}$ year ${ }^{-1}$. Details of feed composition, daily feed intake, $\mathrm{N}$ contents of products, production rounds per year, and feed conversion ratios are included in the guidelines (Ketelaars and Van der Meer, 1999). North Italy (Xiccato et al., 2005) and UK (ADAS, 2007) use these guidelines for the calculation of manure $\mathrm{N}$ production.

\subsubsection{Methodologies used for the OECD/EUROSTAT Gross $N$ balance}

The methodology for deriving the Eurostat/OECD nutrient balances are described in the OECD/Eurostat (2007) Gross Nitrogen Balances Handbook. The following countries submitted country specific N excretion factors to Eurostat for 2011: Austria, Belgium, Czech republic, Denmark, Finland, Germany, Hungary, Ireland, Italy, Malta, Netherlands, Poland, Portugal, Slovakia, Slovenia, and Sweden. Often similar methodologies were used as for the UNFCCC reporting. Some countries have not supplied data to Eurostat/OECD or the data were not compliant with the guidelines in the OECD/Eurostat Handbook. For these countries 
Chapter 2

Eurostat/OECD used the $\mathrm{N}$ excretion factors reported in the 2010 submission of greenhouse gases to the UNFCCC.

\subsubsection{Methodologies used in the GAINS model}

The GAINS model estimates emissions of $\mathrm{NH}_{3}, \mathrm{~N}_{2} \mathrm{O}$ and $\mathrm{CH}_{4}$ from animal manures per livestock category and Member State. GAINS relies on data submitted by national experts, based on a questionnaires (Klimont and Brink, 2004; Asman et al., 2011). The questionnaires included questions for dairy cattle and other cattle, fattening pigs, sows, horses, sheep and goats, laying hens, broilers, other poultry (geese, ducks, turkey), and fur animals. If no national information was provided, assumptions were made. If no country-specific data for dairy cattle was provided, a relationship between milk yield and $\mathrm{N}$-excretion was used: $\mathrm{Nx}=$ $0.0178 \times \mathrm{M}+0.2271$, where $\mathrm{Nx}=\mathrm{N}$ excretion rate $\left(\mathrm{kg} \mathrm{N}\right.$ animal $^{-1}$ year $\left.^{-1}\right)$, and $\mathrm{M}=$ milk yield $\left(\mathrm{kg}\right.$ animal $^{-1}$ year $\left.^{-1}\right)$. The available data do not allow conclusions for milk yields below 3500 $\mathrm{kg}$ milk year ${ }^{-1}$; then a mean $\mathrm{N}$ excretion value of $50 \mathrm{~kg} \mathrm{~N}$ animal $^{-1}$ year $^{-1}$ is assumed, irrespective of milk yield.

\subsubsection{Methodologies used in the CAPRI model}

The CAPRI (Common Agricultural Policy Regional Impact) model is an agricultural sector model covering the whole of EU, Norway and Western Balkans at regional level (250 regions), and links global agricultural markets at country or country block level. Besides economic evaluations, CAPRI is also used for the calculation of balances for $\mathrm{N}, \mathrm{P}, \mathrm{K}$ and greenhouse gas emissions (Leip et al., 2010, 2011). The excretion of $\mathrm{N}$ per animal category is calculated as the difference between $\mathrm{N}$ intake and $\mathrm{N}$ retention of animals. CAPRI includes a feed module in which available feed in a region/country is distributed over the animals in a region, based on energy and nutrient requirements of the animals. Feed statistics from FAO and Eurostat are used. The yields and $\mathrm{N}$ content of grassland are based on estimates made in the MITERRA-model (Velthof et al., 2009).

\subsection{Nitrogen excretion factors}

Table 2-3 shows the calculated $\mathrm{N}$ excretion factors for EU countries using the default IPCC Tier 1 factors, the EMEP/EEA Tier 2 approach, and the gross $\mathrm{N}$ excretions in the Nitrates Directive report. For the Nitrates Directive study, ranges are presented, which reflect differences in breed, $\mathrm{N}$ content of the diet, protein conversion ratio, and live weight. There is 
a wide range in the $\mathrm{N}$ excretion factors of dairy cattle (75 to $184 \mathrm{~kg} \mathrm{~N}$ animal $^{-1}$ year $^{-1}$ ) and other cattle $\left(20-90 \mathrm{~kg} \mathrm{~N}_{\text {animal }}{ }^{-1}\right.$ year $\left.^{-1}\right)$. The IPCC uses defaults for Western and Eastern Europe and EMEP/EEA uses only one default. In the EMEP/EEA Guidelines it is indicated that the default $\mathrm{N}$ excretion data were taken from IPCC. However, it is not indicated if Western or Eastern European excretion coefficients were used and which animal category was selected. For most animal categories, the EMEP/EEA defaults are different from the IPCC defaults, when using the TAM values in the IPCC report. It is not clear how the EMEP/EEA Tier 2 defaults have been obtained for the IPCC Tier 1 defaults. If the ranges provided by the Nitrates Directive report reflect the actual variations in practice, it will be difficult to accept that the default values presented by the IPCC Tier 1 and the EMEP/EEA Tier 2 approaches have high accuracy, even though the factors do not differ much between the two latter approaches.

Table 2-3. $\mathrm{N}$ excretion factors in $\mathrm{kg} \mathrm{N}_{\text {animal }}{ }^{-1} \mathrm{yr}^{-1}$ according to IPCC Tier 1 guidelines, EMEP/EEA Tier 2 guidebook, and recommendations for Nitrates Directive.

\begin{tabular}{|c|c|c|c|c|c|}
\hline \multirow[t]{2}{*}{ Animal } & \multicolumn{2}{|c|}{ IPCC Tier $1^{\mathrm{a}}$} & \multirow{2}{*}{$\begin{array}{c}\text { EMEP/EEA } \\
\text { Tier } 2\end{array}$} & \multirow{2}{*}{$\begin{array}{c}\text { Nitrates } \\
\text { Directive }^{\mathrm{e}}\end{array}$} & \multirow[t]{2}{*}{ Explanation of range in Nitrates Directive factors } \\
\hline & $\begin{array}{l}\text { Western } \\
\text { Europe }\end{array}$ & $\begin{array}{l}\text { Eastern } \\
\text { Europe }\end{array}$ & & & \\
\hline Dairy cattle & 105 & 70 & 105 & $75-184$ & Small breed low $\mathrm{N}$ diet to large breed high $\mathrm{N}$ diet \\
\hline Other cattle & 51 & 50 & 41 & $20-90$ & Growing cattle low $\mathrm{N}$ diet to suckler cow high $\mathrm{N}$ diet \\
\hline Fattening pig $^{\mathrm{b}}$ & 9.3 & 10 & 12 & $12-15$ & High to low protein conversion \\
\hline Sow $^{\mathrm{c}}$ & 30 & 30 & 35 & $32-38$ & High to low protein conversion (incl. piglets $<25 \mathrm{~kg}$ ) \\
\hline Layers $^{\mathrm{d}}$ & 0.63 & 0.54 & 0.77 & $0.64-0.96$ & Good to poor feed conversion \\
\hline Broilers & 0.36 & 0.36 & 0.36 & $0.41-0.61$ & Good to poor feed conversion \\
\hline Turkeys & 1.84 & 1.84 & 1.64 & $1.6-2.5$ & Good to poor feed conversion \\
\hline Ducks & 0.82 & 0.82 & 1.26 & $1.0-1.4$ & Good to poor feed conversion \\
\hline Sheep & 15 & 16 & 16 & $15-30$ & Low to high $\mathrm{N}$ diet (incl. lambs $<40 \mathrm{~kg}$ ) \\
\hline Goats & 18 & 18 & 16 & $16-26$ & Low to high $\mathrm{N}$ diet (incl. lids $<7 \mathrm{~kg}$ ) \\
\hline Horses & 36 & 41 & 48 & $39-67$ & 400 to $800 \mathrm{~kg}$ \\
\hline Rabbits & 8.1 & 8.1 & - & $7-12$ & Low to high $\mathrm{N}$ diet (incl. kittens) \\
\hline
\end{tabular}

${ }^{\mathrm{a}}$ Calculated from IPCC Tier 1 tables with excretion per mass per day and IPCC default mass values (TAM)

${ }^{\mathrm{b}}$ Market swine in IPCC

${ }^{\mathrm{c}}$ Breeding swine in IPCC

${ }^{\mathrm{d}}$ Hens $\geq 1$ yr in IPCC

${ }^{\mathrm{e}}$ Ketelaars and Van der Meer (1999)

Tables 2-4 to 2-7 show the $\mathrm{N}$ excretion factors for dairy cattle and other cattle, pips, poultry, and sheep and goats, respectively, reported in i) the National Inventory Reports (NIR) for 2011, ii) the reports to UNECE Gothenborg protocol for the years 2007 - 2010 (years differ between countries), (iii) the Action Programmes for the Nitrates Directive available for 2011, (iv) the OECD/Nutrient balance for 2011, (v) the GAINS model (Asman et al., 2011) and (vi) 


\section{Chapter 2}

the CAPRI model (Leip et al., 2010). Member states using a Tier 1 approach for the Gothenborg Protocol do not report $\mathrm{N}$ excretion factors. For the Nitrates Directives, only data are presented for countries that present gross $\mathrm{N}$ excretion factors or net $\mathrm{N}$ excretion factors and gaseous $\mathrm{N}$ emission factors from which gross $\mathrm{N}$ excretion can be calculated.

The $\mathrm{N}$ excretion of dairy cattle varied from less than $80 \mathrm{~kg} \mathrm{~N} \mathrm{cow}^{-1} \mathrm{year}^{-1}$ to more than $140 \mathrm{~kg}$ $\mathrm{N} \mathrm{cow}^{-1}$ year $^{-1}$ (Table 2-4). This large range is partly due to differences in breed, $\mathrm{N}$ content of the diet and level of milk production (Ketelaars and Van der Meer, 1999). However, differences in methods and in data combination are also causes of the variation shown in Table 2-4. For nearly all countries, there are differences in $\mathrm{N}$ excretion of dairy cattle between the policy reports. The excretion factors used in National Inventory Reports for UNFCCC and for the Gothenborg protocol are for most member states similar or only lightly different (except Germany; $132 \mathrm{~kg}_{\text {year }}{ }^{-1}$ for NIR 2011 and $114 \mathrm{~kg} \mathrm{year}^{-1}$ for the Gothenborg protocol). The CAPRI estimates were very high for some countries, e.g. $194{\mathrm{~kg} \mathrm{~N} \text { cow }^{-1} \text { year }}^{-1}$ in Denmark and $180 \mathrm{~kg} \mathrm{~N} \mathrm{cow}^{-1}$ year $^{-1}$ in Sweden. One of the uncertainties in calculation of $\mathrm{N}$ excretion of dairy cows, is the estimate of grassland yields and the $\mathrm{N}$ content of the grassland (Velthof et al., 2009). Grassland yields are not yet recorded in statistics, as harvested and grazed grass is generally used on the own farm. Lesschen et al. (2011) estimated that the EU livestock sector uses around 500 million tonnes of animal feed per year, $40 \%$ of which is grass (expressed in dry matter). Grasslands are highly diverse in terms of management, yield and biodiversity value, which has a large effect on the $\mathrm{N}$ and $\mathrm{P}$ content of the herbage (Whitehead, 2000). Calculations show that the $\mathrm{N}$ excretion of dairy cows decreases on average with $0.17 \mathrm{~kg} \mathrm{~N} \mathrm{~kg}^{-1}$ decrease in fertilizer $\mathrm{N}$ input, in the range of 200 to $400 \mathrm{~kg} \mathrm{~N} \mathrm{ha}^{-1}$ year $^{-1}$ (Velthof et al., 2014).

The category 'other cattle' consists of cattle with different breeds, weight and age, and thereby with large differences in $\mathrm{N}$ excretion factors, from less than $15 \mathrm{~kg} \mathrm{~N}$ head ${ }^{-1}$ for calves to more than $75 \mathrm{~kg} \mathrm{~N}$ for beef cattle and suckling cows (Table 2-4). This hampers the estimation of an average excretion rates for the category "other cattle". Evidently, excretion factors for the different functional categories within the category 'other cattle' have to be estimated first, and then aggregated proportionally to arrive at a mean excretion factor for 'other cattle'. The dominant functional categories within other cattle should be described as well to allow comparison. In conclusion, it is recommended to estimate excretion factors for functional cattle categories within other cattle instead of using an average excretion factor for 
"other cattle". This is also needed because the excretion factors have to be multiplied with the appropriate number of animals, which mostly are registered for detailed categories. This procedure leads to a transparent and accurate estimation of the $\mathrm{N}$ excretion factor for other cattle.

There is also large variation in $\mathrm{N}$ excretion factors for pigs (Table 2-5). The $\mathrm{N}$ excretion factors for pigs in NIR range from $8.4 \mathrm{~kg} \mathrm{~N}$ head $^{-1}$ per year for Denmark to $20 \mathrm{~kg} \mathrm{~N}_{\text {head }}{ }^{-1}$ per year $^{-1}$ for Romania and Czech Republic. The pig category also consists of a large number of different types (breeds, sex, age, weight). Further, it may not be excluded that some countries express the $\mathrm{N}$ excretion factors on an animal head basis and others on an animal place basis. For sows, it is important to report whether piglets are included or not (and till which weight and age). The CAPRI model calculates livestock feed using a feed distribution tool and data from market balances on a country level, regional fodder availability and animal requirements (Leip et al., 2010). The CAPRI estimates for $\mathrm{N}$ excretion factors for pigs are much higher than that for the other methods (Table 2-5).

The same comments as for other cattle and pigs hold for poultry. There is a large diversity in poultry categories (laying hens, broilers, turkey, ducks etc.), which hampers the use of one excretion factor for one poultry category. There are sometimes large differences in $\mathrm{N}$ excretion factors between countries, which are difficult to explain (Table 2-6). Differences may be partly due to differences in age/weight, and unit (animal head or animal place).

Large differences in $\mathrm{N}$ excretion factors between sheep categories are shown in the UNFCCC report; $\mathrm{N}$ excretion factors range from $5.2 \mathrm{~kg} \mathrm{~N}$ head $^{-1}$ for Spain to $20 \mathrm{~kg} \mathrm{~N}^{\mathrm{N}} \mathrm{hed}^{-1}$ in Slovenia (Table 2-7). Also the figures used for the Nitrates Directive show large differences for sheep. These differences may partly be due to differences in the way male, female and young animals are considered in the excretion calculation. 


\section{Chapter 2}

Table 2-4. Gross nitrogen excretion factors for dairy cows and other cattle $\left(\mathrm{kg} \mathrm{N}_{\mathrm{N}} \mathrm{ad}^{-1} \mathrm{yr}^{-1}\right)$ in EU-27 for different sources.

\begin{tabular}{|c|c|c|c|c|c|c|c|c|c|c|c|c|}
\hline \multicolumn{7}{|c|}{ Dairy cows } & \multicolumn{6}{|c|}{ Other cattle } \\
\hline Country & $\begin{array}{c}\text { NIR } \\
(2011)\end{array}$ & $\begin{array}{l}\text { UNECE } \\
(2007- \\
2010)\end{array}$ & $\begin{array}{l}\text { Nitrates } \\
\text { Directive } \\
(2011)^{a}\end{array}$ & $\begin{array}{c}\text { OECD/ } \\
\text { Eurostat } \\
(2011)\end{array}$ & $\begin{array}{l}\text { CAPRI } \\
(2004)\end{array}$ & $\begin{array}{l}\text { GAINS } \\
(2010)\end{array}$ & $\begin{array}{c}\text { NIR } \\
(2011)^{\mathrm{b}}\end{array}$ & $\begin{array}{l}\text { UNECE } \\
(2007- \\
2010)^{\mathrm{a}}\end{array}$ & $\begin{array}{l}\text { Nitrates } \\
\text { Directive } \\
(2011)^{\mathrm{a}}\end{array}$ & $\begin{array}{c}\text { OECD/ } \\
\text { Eurostat } \\
(2011)^{\mathrm{a}}\end{array}$ & $\begin{array}{l}\text { CAPRI } \\
(2004)\end{array}$ & $\begin{array}{l}\text { GAINS } \\
(2010)\end{array}$ \\
\hline Austria & 97 & 97 & - & 97 & 90 & 106 & 47 & $26-74$ & - & $15-69$ & 40 & 46 \\
\hline Belgium & 115 & - & - & 109 & 95 & 118 & 54 & - & - & - & 47 & 50 \\
\hline Walloon & - & 121 & - & 111 & - & - & - & $11-97$ & - & $11-77$ & - & - \\
\hline Flanders & - & 97 & 97 & 106 & - & - & - & $13-98$ & $23-61$ & $11-77$ & - & - \\
\hline Bulgaria & 70 & - & - & - & 116 & 75 & 50 & 45 & - & - & 49 & 45 \\
\hline Cyprus & - & - & - & 107 & 134 & 103 & - & - & - & $19-48$ & 43 & 40 \\
\hline Czech Rep. & 145 & - & - & 105 & 114 & 131 & 70 & - & - & $20-60$ & 43 & 45 \\
\hline Denmark & 138 & 138 & - & 129 & 194 & 132 & 48 & - & - & $11-66$ & 62 & 37 \\
\hline Estonia & 102 & - & - & 62 & 122 & 113 & 44 & - & - & $11-45$ & 42 & 45 \\
\hline Finland & 127 & 122 & - & - & 92 & 121 & 50 & $38-66$ & - & $16-51$ & 30 & 53 \\
\hline France & 100 & - & - & 125 & 105 & 112 & 58 & - & - & $53-67$ & 53 & 50 \\
\hline Germany & 132 & 114 & $100-149$ & 119 & 106 & 130 & 41 & $44-88$ & $60-87$ & 84 & 40 & 40 \\
\hline Greece & 100 & - & - & - & 97 & 111 & 45 & - & - & 25 & 47 & 45 \\
\hline Hungary & 114 & - & - & 125 & 149 & 146 & 48 & - & - & $12-65$ & 51 & 45 \\
\hline Ireland & 85 & - & 85 & 109 & 88 & 105 & 49 & - & $24-65$ & $14-55$ & 48 & 69 \\
\hline Italy & 116 & 116 & - & 94 & 97 & 112 & 49 & 50 & - & $63-74$ & 39 & 47 \\
\hline Latvia & 70 & - & - & 70 & 139 & 88 & 50 & - & - & - & 57 & 51 \\
\hline Lithuania & 99 & - & 120 & - & 99 & 95 & 58 & - & $33-95$ & - & 38 & 50 \\
\hline Luxembourg & 102 & - & - & 71 & - & 114 & 68 & - & - & 10 & - & 42 \\
\hline Malta & - & - & - & 103 & 155 & 98 & - & - & & $10-28$ & 51 & 40 \\
\hline Netherlands & 127 & 130 & $99-131$ & 135 & 119 & 147 & 83 & $12-83$ & $35-71$ & $16-75$ & 38 & 40 \\
\hline Poland & 87 & - & - & 70 & 91 & 81 & 58 & - & - & $36-40$ & 36 & 35 \\
\hline Portugal & 115 & 112 & - & 112 & 121 & 102 & 51 & $25-80$ & - & $25-55$ & 68 & 50 \\
\hline Romania & 70 & - & - & & 96 & 67 & 50 & - & - & 21 & 39 & 53 \\
\hline Slovakia & 100 & - & - & 105 & 119 & 135 & 60 & - & - & $21-60$ & 42 & 45 \\
\hline Slovenia & 111 & - & - & 113 & 85 & 110 & 42 & - & - & $27-35$ & 38 & 40 \\
\hline Spain & 68 & 68 & 89 & 103 & 108 & 71 & 53 & 52 & - & $21-73$ & 51 & 45 \\
\hline Sweden & 126 & 125 & $117-139$ & 117 & 180 & 132 & 42 & $28-63$ & $22-63$ & $26-57$ & 61 & 39 \\
\hline UK & 110 & - & - & 117 & 142 & 133 & 55 & - & - & $31-63$ & 53 & 49 \\
\hline
\end{tabular}

${ }^{\mathrm{a}}$ Range in $\mathrm{N}$ excretion factors indicate that more categories of cows are included, e.g. suckler cows, calves, young cattle ( $<1 \mathrm{yr}$ or $\left.>1 \mathrm{yr}\right)$, or bulls.

${ }^{b}$ Data: from common reporting format (CRF) of greenhouse gas inventory submission of 2011. 
Table 2-5. Gross nitrogen excretion factors $\left(\mathrm{kg} \mathrm{N}\right.$ head $\left.^{-1} \mathrm{yr}^{-1}\right)$ for pigs.

\begin{tabular}{|c|c|c|c|c|c|c|}
\hline Country & $\begin{array}{c}\text { NIR } \\
(2011)^{\mathrm{a}}\end{array}$ & $\begin{array}{c}\text { UNECE } \\
(2007- \\
2010)^{b}\end{array}$ & $\begin{array}{l}\text { Nitrates } \\
\text { Directive } \\
(2011)^{\mathrm{b}}\end{array}$ & $\begin{array}{l}\text { OECD/ } \\
\text { Eurostat } \\
(2011)^{\mathrm{b}}\end{array}$ & $\begin{array}{l}\text { CAPRI } \\
(2004)\end{array}$ & $\begin{array}{c}\text { GAINS } \\
(2010)\end{array}$ \\
\hline Austria & 9.6 & $10-29$ & - & $4-24$ & 17.3 & 9.0 \\
\hline Belgium & 10.1 & - & - & - & 18.4 & 11.1 \\
\hline Walloon & - & $2-22$ & - & $2-21$ & - & - \\
\hline Flanders & - & $5-43$ & $13-24$ & $2-21$ & - & - \\
\hline Bulgaria & 20.0 & - & - & 20 & 21.6 & 12.4 \\
\hline Cyprus & - & - & - & $3-25$ & 21.5 & 12.4 \\
\hline Czech Rep. & 20.0 & - & - & $4-21$ & 19.8 & 12.4 \\
\hline Denmark & 8.4 & 8 & - & $2-23$ & 22.8 & 9.6 \\
\hline Estonia & 12.9 & - & - & $1-30$ & 18.1 & 12.4 \\
\hline Finland & - & $3-29$ & - & $3-26$ & 12.3 & 10.1 \\
\hline France & 16.5 & - & - & $1-29$ & 16.6 & 12.2 \\
\hline Germany & 12.1 & $3-28$ & $12-35$ & - & 18.4 & 14.8 \\
\hline Greece & 16.0 & - & - & - & 16.1 & 11.5 \\
\hline Hungary & 8.1 & - & - & $3-27$ & 26.9 & 8.9 \\
\hline Ireland & 8.5 & - & $9-35$ & $3-24$ & 15.2 & 12.4 \\
\hline Italy & 11.8 & $13-28$ & - & $4-26$ & 20.0 & 11.5 \\
\hline Latvia & 10.0 & - & - & 20 & 24.4 & 10.0 \\
\hline Lithuania & 12.3 & - & $5-43$ & 12 & 17.5 & 12.4 \\
\hline Luxembourg & 11.9 & - & - & 10 & - & 9.9 \\
\hline Malta & - & - & - & $3-28$ & 24.1 & 12.4 \\
\hline Netherlands & 8.9 & $12-30$ & $9-22$ & $13-31$ & 15.8 & 9.2 \\
\hline Poland & 13.6 & - & - & $3-15$ & 16.6 & 11.1 \\
\hline Portugal & 9.5 & $7-42$ & - & $7-42$ & 19.9 & 9.1 \\
\hline Romania & 20.0 & - & - & 20 & 18.8 & 12.4 \\
\hline Slovakia & 15.8 & - & - & $3-22$ & 18.0 & 12.4 \\
\hline Slovenia & 11.9 & - & - & $14-36$ & 15.0 & 11.9 \\
\hline Spain & 9.4 & $7-22$ & $10-24$ & $2-23$ & 17.5 & 9.4 \\
\hline Sweden & 9.1 & $11-34$ & 11 & $2-27$ & 21.3 & 11.0 \\
\hline UK & 10.6 & - & - & $2-25$ & 17.6 & 12.4 \\
\hline
\end{tabular}

${ }^{\mathrm{a} D a t a}$ from common reporting format (CRF) of greenhouse gas inventory submission of 2011 .

${ }^{\mathrm{b}}$ Range in $\mathrm{N}$ excretion factors indicate that more categories of pigs are included. 


\section{Chapter 2}

Table 2-6. Gross nitrogen excretion factors $\left(\mathrm{kg} \mathrm{N} \mathrm{head}^{-1} \mathrm{yr}^{-1}\right)$ for poultry (NIR 2011, and CAPRI), laying hens (UNECE, Nitrates Directive, OECD/Eurostat, GAINS) and broilers (UNECE, Nitrates Directive, OECD/Eurostat).

\begin{tabular}{|c|c|c|c|c|c|c|c|c|c|}
\hline & \multirow{2}{*}{$\begin{array}{c}\text { NIR } \\
(2011)^{\mathrm{a}} \\
\text { Poultry }\end{array}$} & \multicolumn{2}{|c|}{ UNECE (2007-2010) } & \multicolumn{2}{|c|}{$\begin{array}{c}\text { Nitrates Directive } \\
\text { (2011) }\end{array}$} & \multicolumn{2}{|c|}{ OECD/Eurostat (2011) } & \multirow{2}{*}{$\begin{array}{l}\text { CAPRI } \\
(2004) \\
\text { Poultry }\end{array}$} & \multirow{2}{*}{$\begin{array}{c}\text { GAINS } \\
(2010) \\
\text { Laying hens } \\
\end{array}$} \\
\hline & & Laying hens & Broilers & Laying hens & Broilers & Laying hens & Broilers & & \\
\hline Austria & 0.55 & 0.52 & - & - & - & 0.72 & 0.28 & 0.49 & 0.73 \\
\hline Belgium & 0.58 & 0.74 & - & - & - & - & 0.55 & 0.42 & 0.70 \\
\hline Walloon & - & - & - & - & - & - & 0.54 & - & - \\
\hline Flanders & - & - & - & - & - & - & 0.60 & - & - \\
\hline Bulgaria & 0.60 & - & - & - & - & - & - & 0.68 & 0.80 \\
\hline Cyprus & - & - & - & - & - & 0.63 & 0.32 & 0.58 & 0.80 \\
\hline Czech Rep. & 0.60 & - & - & - & - & 0.60 & 0.35 & 0.56 & 0.80 \\
\hline Denmark & 0.53 & 0.79 & - & - & - & 1.11 & 0.63 & 0.84 & 0.71 \\
\hline Estonia & 0.60 & - & 0.40 & - & - & 0.78 & 0.23 & 0.58 & 0.80 \\
\hline Finland & 0.58 & 0.67 & - & - & - & 0.64 & 0.48 & 0.43 & 0.80 \\
\hline France & 0.60 & - & 0.55 & - & - & - & - & 0.61 & 0.80 \\
\hline Germany & 0.78 & 0.84 & - & $0.75-0.79$ & $0.31-0.47$ & 0.78 & 0.37 & 0.52 & 0.84 \\
\hline Greece & 0.60 & - & - & - & - & - & - & 0.52 & 0.80 \\
\hline Hungary & 0.60 & - & - & - & - & 0.74 & 0.38 & 0.69 & 1.50 \\
\hline Ireland & 0.31 & - & - & 0.56 & 0.24 & - & 0.60 & 0.47 & 0.84 \\
\hline Italy & 0.53 & - & - & - & - & 0.66 & 0.38 & 0.47 & 0.66 \\
\hline Latvia & 0.60 & - & - & - & - & - & - & 0.83 & 0.90 \\
\hline Lithuania & 0.60 & - & - & $0.8-0.87$ & 0.12 & - & - & 0.61 & 0.80 \\
\hline Luxembourg & 0.74 & - & - & - & - & - & - & - & 0.80 \\
\hline Malta & - & - & 0.50 & - & - & 0.57 & 0.04 & 0.62 & 0.80 \\
\hline Netherlands & 0.65 & - & - & 0.37 & 0.36 & - & 0.53 & 0.49 & 0.67 \\
\hline Poland & 0.35 & - & 0.45 & - & - & 0.70 & 0.14 & 0.58 & 0.70 \\
\hline Portugal & 0.56 & 0.80 & - & - & - & 0.80 & 0.45 & 0.64 & 0.60 \\
\hline Romania & 0.60 & - & - & - & - & - & - & 0.58 & 0.78 \\
\hline Slovakia & 0.73 & - & - & - & - & 0.70 & 0.30 & 0.62 & 0.80 \\
\hline Slovenia & 0.60 & - & 0.43 & - & - & 0.71 & 0.40 & 0.43 & 0.71 \\
\hline Spain & 0.45 & 0.49 & 0.29 & 0.80 & 0.60 & 0.49 & 0.42 & 0.56 & 0.80 \\
\hline Sweden & 0.40 & 0.64 & - & 0.60 & 0.28 & 0.73 & 0.28 & 0.73 & 0.64 \\
\hline UK & 0.57 & - & - & - & - & 1.89 & 0.51 & 0.58 & 0.85 \\
\hline
\end{tabular}

${ }^{\mathrm{a}}$ Data: from common reporting format (CRF) of greenhouse gas inventory submission of 2011. 
Nitrogen excretion factors of livestock: a review

Table 2-7. Gross nitrogen excretion factors $\left(\mathrm{kg} \mathrm{N}\right.$ head $\left.{ }^{-1} \mathrm{yr}^{-1}\right)$ for sheep and goats in EU-27.

\begin{tabular}{|c|c|c|c|c|c|c|c|c|c|c|}
\hline \multirow[t]{2}{*}{ Country } & \multicolumn{2}{|c|}{$\operatorname{NIR}(2011)^{\mathrm{a}}$} & \multicolumn{2}{|c|}{ UNECE (2007-2010) } & \multicolumn{2}{|c|}{ Nitrates Directive (2010) } & \multicolumn{2}{|c|}{ OECD/ Eurostat (2011) } & \multirow{2}{*}{$\begin{array}{l}\text { CAPRI (2004) } \\
\text { Sheep and goats }\end{array}$} & \multirow{2}{*}{$\begin{array}{r}\text { GAINS (2010) } \\
\text { Sheep and goats } \\
\end{array}$} \\
\hline & Sheep & Goats & Sheep & Goats & Sheep & Goats & Sheep & Goats & & \\
\hline Austria & 13.1 & 12.3 & 13.1 & 12.3 & - & - & - & 13.1 & 5.2 & 13.0 \\
\hline Belgium & 7.5 & 8.4 & $8.8-10.5$ & $8.8-10.5$ & - & - & 8.9 & 8.3 & 5.5 & 7.4 \\
\hline Walloon & $n-$ & - & - & - & - & - & 10.2 & 9.2 & - & - \\
\hline Flanders & $s \quad-$ & - & - & - & - & - & 7.4 & 7.1 & - & - \\
\hline Bulgaria & 14.7 & 17.0 & - & - & - & - & 14.7 & 17.0 & 9.5 & 12.0 \\
\hline Cyprus & - & - & - & - & - & - & 9.5 & 11.2 & 9.2 & 12.0 \\
\hline Czech Rep. & 20.0 & 25.0 & - & - & - & - & 9.8 & 9.8 & 4.7 & 12.0 \\
\hline Denmark & 15.3 & 16.4 & 17.0 & 16.3 & - & - & - & - & 8.8 & 17.0 \\
\hline Estonia & 16.0 & 25.0 & - & - & - & - & 14.0 & 14.0 & 6.5 & 14.0 \\
\hline Finland & 10.0 & 10.7 & 10.0 & 10.7 & - & - & 10.0 & 10.7 & 4.0 & 16.0 \\
\hline France & 18.3 & 25.0 & - & - & - & - & 18.3 & 25.0 & 7.7 & 12.0 \\
\hline Germany & 7.4 & 11.0 & 7.8 & 11.0 & $18.1-18.6$ & 14.8 & - & 14.8 & 5 & 7.5 \\
\hline Greece & 10.7 & 12.0 & - & - & - & - & - & - & 7.9 & 12.0 \\
\hline Hungary & 20.0 & 18.0 & - & - & - & - & - & 14.6 & 7.9 & 12.0 \\
\hline Ireland & 6.3 & 9.0 & - & - & $7-13$ & 9 & 10.6 & 12.9 & 5.1 & 8.0 \\
\hline Italy & 16.2 & 16.2 & 16.2 & 16.2 & - & - & 12.8 & 13.5 & 6.2 & 16.2 \\
\hline Latvia & 13.0 & 13.0 & - & - & - & - & 6.0 & 6.0 & 10.8 & 7.0 \\
\hline Lithuania & 16.0 & 16.0 & - & - & 12 & $10-12$ & 16.0 & 16.0 & 6.7 & 12.0 \\
\hline Luxembourg & 17.0 & 17.0 & - & - & - & - & 17.0 & 17.0 & - & 12.0 \\
\hline Malta & - & - & - & - & - & - & 9.1 & - & 8.3 & 12.0 \\
\hline Netherlands & 6.7 & 9.9 & 14.1 & 17.5 & $7.4-10.2$ & $3.1-5.8$ & - & - & 4.8 & 11.5 \\
\hline Poland & 6.8 & 6.7 & - & - & - & - & 8.0 & 7.0 & 6.2 & 13.7 \\
\hline Portugal & 7.1 & 6.0 & 6.6 & - & - & - & - & - & 8.4 & 7.0 \\
\hline Romania & 16.0 & 25.0 & - & - & - & - & 16.0 & 25.0 & 7.8 & 5.2 \\
\hline Slovakia & 16.0 & 16.0 & - & - & - & - & - & 10.0 & 6.9 & 12.0 \\
\hline Slovenia & 20.0 & 25.0 & - & - & - & - & 20.0 & - & 5.0 & 11.3 \\
\hline Spain & 5.2 & 11.3 & 5.1 & 11.3 & 10.0 & 8.8 & 6.6 & 9.0 & 6.8 & 12.0 \\
\hline Sweden & 6.1 & 8.7 & 13.0 & - & 14.0 & - & 13.0 & 11.3 & 8.2 & 6.1 \\
\hline UK & 5.2 & 20.6 & - & - & - & - & - & - & - & 6.4 \\
\hline
\end{tabular}

${ }^{\mathrm{a} D a t a}$ : from common reporting format (CRF) of greenhouse gas inventory submission of 2011. 


\section{Chapter 2}

\subsection{Need for harmonization of methods and data}

Our comparison of the excretion factors between policy reports and between countries shows large differences. The differences in $\mathrm{N}$ excretion factors between countries result from differences in animal productivity and animal husbandry practices, but also from differences in animal categorization and aggregation, calculation methods, year of reporting or data collection, data and information collection/processing/reporting procedures, and adjustments for the actual length of the production cycle. These adjustments are necessary to allow for non-productive time needed for cleaning and re-stocking the housings. A difference in the calculated $\mathrm{N}$ excretion between member states due to methodology is unacceptable for policies and calculation of total excretion and emissions in EU, and therefore there is a need for harmonization of methodologies.

The $\mathrm{N}$ excretion factor has a large effect on the calculated $\mathrm{NH}_{3}$ and $\mathrm{N}_{2} \mathrm{O}$ emissions, and $\mathrm{N}$ surplus. The emission factors for $\mathrm{NH}_{3}$ and $\mathrm{N}_{2} \mathrm{O}$ are expressed in percent of $\mathrm{N}$ excreted or $\mathrm{N}$ applied to soil (Hyde et al., 2003; Dämmgen et al., 2006; IPCC 2006; Gac et al., 2007; Hutchings et al., 2011; Oenema et al., 2011; Velthof et al., 2012; EEA, 2013). Evidently, variations in $\mathrm{N}$ excretion factors affect the calculated emissions directly. Thus, large variations in $\mathrm{N}$ excretion factors between member states have a large effect on the reported emissions. Emission reduction targets for $\mathrm{NH}_{3}$ and $\mathrm{N}_{2} \mathrm{O}$ are set by UNFCCC, UNECE and the European Commission. Manure application standards set by the European Commission have less meaning if $\mathrm{N}$ excretion factors have low accuracy. Evidently, there is a clear need for a robust, common, harmonized approach for estimating $\mathrm{N}$ excretion factors, so that the emissions reported by member states have a common and transparent basis and can be used for estimates of total emission in the EU.

Any common, universal approach must account for the differences between countries in (i) the importance of livestock production, and hence in the relative magnitude of $\mathrm{N}$ and $\mathrm{P}$ excretion as a source of $\mathrm{N}$ and $\mathrm{P}$, (ii) the type of livestock production systems (animal species, animal housing, animal feeding), and (iii) in the data and information collection infrastructure. This holds especially also for the EU, where livestock density may range from an average of less than 0.5 livestock units (LSU) per ha to more than 3 LSU per ha. Also, some countries have relatively large populations of cattle (dairy and/or beef), while other countries have relatively more pigs or poultry or sheep or goat. Countries with a high livestock density 
commonly have developed a more detailed infrastructure for data and information collection than countries with a low livestock density.

The first step would be the definition of animal categories for which excretion figures have to be calculated. These are preferably categories for which animals number are gathered, so that total manure production in regions and countries can be made. For the EU, it is recommended to use animal categories in the Farm Structure Survey (European Commission, 2009) as a basis. It is also recommended to harmonize the livestock categories in the different policy reporting streams or develop procedures to aggregate or disaggregate livestock categories for the $\mathrm{N}$ excretion calculation. This is especially important for other cattle, pigs, and poultry, as these categories include livestock types with a large difference in $\mathrm{N}$ excretion.

The second step would be to recommend a set of methodologies with different levels of detail (i.e. a Tiered approach) to estimate the $\mathrm{N}$ excretion for each category. The accuracy of the balance method to calculate excretion is higher than that of estimation on basis of measured manure composition. The variability of $\mathrm{N}$ contents in manure is large (Table 2-1) and accuracy of weighing or measurement of volumes of manure on animal or farm scale is often low. The uncertainties in data needed for the balance are generally lower than those of measurement of manure composition and amount of manure. Therefore, the basis for the calculation of $\mathrm{N}$ excretion factors should be the balance method, i.e., $\mathrm{N}$ excretion $=$ feed $\mathrm{N}$ intake $-\mathrm{N}$ retention in the animal and animal products. The Tier 1 approach is the most simple approach and would be an approach with default $\mathrm{N}$ excretion figures for certain regions or farming systems (depending on intensity). In other Tier levels, harmonized methodologies to calculate $\mathrm{N}$ excretion data are needed, which use available information for productivity and inputs on regional to national scales and are updated every $1-5$ years.

The third step is the harmonization of collection and processing of data, such as feed intake per animal category, feed production (e.g. grassland yields) and composition (e.g. protein content of grassland), animal production (e.g. production of meat, milk, and eggs), and the composition of animal products. For accurate estimates of $\mathrm{N}$ excretion of dairy cows, there is a need for accurate estimates of grassland yields and $\mathrm{N}$ uptake. Estimates of grassland yields can be based on empirical data (field experiments), results of crops models, expert estimates, and feed balances of dairy cattle (i.e. the feed $\mathrm{N}$ intake can be estimated from the milk yield). 
Chapter 2

Common methodologies for $\mathrm{N}$ excretion calculation and data collection would allow for a harmonized and transparent estimation of actual $\mathrm{N}$ excretion, and hence for a common basis for the estimation and sound comparison of manure $\mathrm{N}, \mathrm{N}$ balances, and $\mathrm{NH}_{3}$ and $\mathrm{N}_{2} \mathrm{O}$ emissions in different member states and EU policies.

\section{Acknowledgements}

The research reported in this paper was financially supported by Eurostat (Project Methodological studies in the field of Agro-Environmental Indicators. Lot 1 excretion factors. Contract number 40701.2012.002-2012.312). The results of Table 2-1 are derived from a study for the Dutch Ministry of Economic Affairs (BO-20-004-013). Y. Hou was financially supported by the People Programme (Marie Curie Actions) of the European Union's Seventh Framework Programme FP7/2007-2013/under REA grant agreement no 289887. The results and conclusions achieved reflect only the author's view and the Union is not liable for any use that may be made of the information contained therein. 


\section{References}

ADAS (2007) Nitrogen output of livestock excreta. ADAS report to Defra - supporting paper F2 for the consultation on implementation of the Nitrates Directive in England. Wolverhampton :ADAS, $59 \mathrm{p}$.

Asman WAH, Klimont Z, Winiwarter W (2011) A Simplified Model of Nitrogen Flows from Manure Management. Laxenburg, Austria: IIASA Interim Report IR-11-030 (October 2011).

Camargo JA and Alonso A (2006) Ecological and toxicological effects of inorganic nitrogen pollution in aquatic ecosystems: A global assessment. Environment International, 32, 831-849.

Dämmgen U, Lüttich M, Döhler H, Eurich-Menden B, Osterburg B (2006) Calculations of emissions from German Agriculture-National Emission Inventory Report (NIR) 2006 for 2004. Part 3: Methods and data (GAS-EM). Landbauforschung Völkenrode (291), 47-221.

European Commission (1991) Council Directive 91/676/EEC of 12 December 1991 concerning the protection of waters against pollution caused by nitrates from agricultural sources. Brussels, Official Journal of the European Union, L 375 [31/12/1991].

European Commission (2001) Directive 2001/81/EC of the European Parliament and of the Council of 23 October 2001 on national emission ceilings for certain atmospheric pollutants. Brussels, Official Journal of the European Union, L 309/22 [27/11/2001].

European Commission (2006) Communication from the Commission to the Council and the European Parliament - Development of agri-environmental indicators for monitoring the integration of environmental concerns into the common agricultural policy $\{\operatorname{SEC}(2006) 1136\}$ $\mathrm{COM} / 2006 / 0508$ final.

European Commission (2009) Commission Regulation (EC) No 1200/2009 implementing Regulation (EC) No 1166/2008 of the European Parliament and of the Council on farm structure surveys and the survey on agricultural production methods, as regards livestock unit coefficients and definitions of the characteristics. Brussels: Official Journal of the European Union, L 329/1.

European Environment Agency (EEA) (2013) EMEP/EEA air pollutant emission inventory guidebook 2013. Technical guidance to prepare national emission inventories EEA Technical report No 12/2013. Publications Office of the European Union, Luxembourg.

Gac A, Béline F, Bioteau T, Maguet K (2007) A French inventory of gaseous emissions $\left(\mathrm{CH}_{4}, \mathrm{~N}_{2} \mathrm{O}\right.$, $\mathrm{NH}_{3}$ ) from livestock manure management using a massflow approach. Livestock Science, 112, 252-260.

Hutchings NJ, Sommer SG, Andersen JM, Asman WAH (2001) A detailed ammonia emission inventory for Denmark. Atmospheric Environment, 35, 1959-1968.

Hyde BP, Carton OT, O'toole P, Misselbrook TH (2003) A new inventory of ammonia emissions from Irish agriculture. Atmospheric Environment, 37, 55-62.

Intergovernmental Panel on Climate Change (IPCC) (2006) 2006 IPCC Guidelines for National Greenhouse Gas Inventories. Prepared by the National Greenhouse Gas Inventories Programme, Eggleston H.S., Buendia L., Miwa K., Ngara T. and Tanabe K. (eds). Kanagawa, Japan: IGES.

Intergovernmental Panel on Climate Change (IPCC) (2014) Climate Change 2014. Synthesis Report. IPCC Fifth Assessment Synthesis Report. Intergovernmental Panel on Climate Change, IPCC, Geneva, Switzerland, $151 \mathrm{pp}$.

Ketelaars JJMH and Van der Meer HG (1999) Establishment of criteria for the assessment of the nitrogen content of animal manures. Report 14. Final report to ERM. Wageningen: Plant Research International, $64 \mathrm{pp}$.

Klimont Z and Brink C (2004) Modelling of emissions of air pollutants and greenhouse gases from agricultural sources in Europe. Laxenburg, Austria: IIASA IR 04-048. 
Leip A, Britz W, Weiss F, De Vries W (2011) Farm, land, and soil nitrogen budgets for agriculture in Europe calculated with CAPRI. Environmental Pollution, 159, 3243-53.

Leip A, Weiss F, Wassenaar T, Perez I, Fellmann T, Loudjani P, Tubiello F, Grandgirard D, Monni S, Biala K (2010). Evaluation of the livestock sector's contribution to the EU greenhouse gas emissions (GGELS) - final report. Ispra, Italy: European Commission, Joint Research Centre.

Lesschen JP, Witzke HP, van den Berg M, Westhoek H, O Oenema (2011) Greenhouse gas emission profiles of the European livestock sectors. Animal Feed Science and Technology, 166- 167: $16-28$.

Moldanová J, Grennfelt P, Jonsson Å, Simpson D, Spranger T, Aas W, Munthe J, Rabl A (2011) Nitrogen as a threat to European air quality. In: Sutton MA, Howard CM, Erisman JW, Billen G, Bleeker A, Grennfelt P, Van Grinsven H, Grizzetti B, editors. The European nitrogen assessment. Cambridge, UK: Cambridge University Press; 2011. p. 405-433.

Nicholson FA, Chambers BJ, Smith KA (1996) Nutrient composition of poultry manures in England and Wales. Bioresource Technology, 58, 279-284.

OECD (2013) OECD Compendium of Agri-environmental Indicators. OECD Publishing, Paris, 190 p.

OECD/Eurostat (2007) Gross Nitrogen Balances Handbook. OECE/Eurostat, Luxembourg.

Oenema O, Amon B, van Beek C, Hutchings N, Perez-Soba M, Procter C, Pietrzak S, Velthof GL, Vinther F, Wilson L (2011) Farm data needed for Agri-environmental reporting. Technical document summarizing the findings of the DireDate project for the Final Seminar in Luxembourg on 28 March 2011. Eurostat report KS-RA-11-005 Luxembourg: Publications Office of the European Union.

Oenema O, Bleeker A, Braathen NA, Budňáková M, Keith Bull K, Čermák P, et al. (2011) Nitrogen in current European policies. In: Sutton MA, Howard CM, Erisman JW, Billen G, Bleeker A, Grennfelt P, Van Grinsven H, Grizzetti B, editors. The European nitrogen assessment. Cambridge, UK: Cambridge University Press; 2011. p. 62-81.

Ravishankara AR, Daniel JS, Portmann RW (2009) Nitrous Oxide $\left(\mathrm{N}_{2} \mathrm{O}\right)$ : The Dominant OzoneDepleting Substance Emitted in the 21st Century. Science, 326, 123-125.

Reidy B, Dämmgen U, Döhler H, Eurich-Menden B, Evert FK, van Hutchings NJ, Luesink, HH, Menzi H, Misselbrook TH, Monteny GJ, Webb J (2008) Comparison of models used for the calculation of national ammonia emission inventories in Europe: liquid manure systems. Atmospheric Environment, 42, 3452-3464.

Sutton MA, Howard C, Erisman JW, Billen G, Bleeker A., Grennfelt P et al. (2011) The European nitrogen assessment: sources, effects and policy perspectives (Eds.) Cambridge UK: Cambridge University Press, 612 pp.

UNECE (1999) Protocol to the 1979 convention on long-range transboundary air pollution to abate acidification, eutrophication and ground-level ozone (Gothenburg protocol).

UNFCCC (1997) Kyoto Protocol to the United Nations Framework Convention on Climate Change. United Nations, New York.

Van Bruggen C (2014) Review of mineral contents in livestock manure - Actualisation of Annex I of Implementing Regulation for the Fertilizer Act. Statistics Netherlands (CBS). Annex to advice of Scientific Committee on the Manure Act (CDM) 14/N\&M0067. Wageningen: CDM, (In Dutch).

Velthof GL, Lesschen JP, Webb J, Pietrzak S, Miatkowski Z, Pinto M, Kros J, Oenema O (2014) The impact of the Nitrates Directive on nitrogen emissions from agriculture in the EU-27 during 2000-2008. Science of the Total Environment, 468-469, 1225-1233.

Velthof GL, Oudendag D, Witzke HP, Asman WAH, Klimont Z, Oenema O (2009) Integrated Assessment of Nitrogen Losses from Agriculture in EU-27 using MITERRA-EUROPE. Journal of Environmental Quality, 38, 402-417. 
Velthof GL, van Bruggen C, Groenestein CM, de Haan BJ, Hoogeveen MW, Huijsmans JFM (2012) A model for inventory of ammonia emissions from agriculture in the Netherlands. Atmospheric Environment, 46, 248-255.

Webb J and Misselbrook TH (2004) A mass-flow model of ammonia emissions from UK livestock production. Atmospheric Environment, 38, 2163-2176.

Webb J, Sørensen P, Velthof GL, Amon B, Pinto M, Rodhe L, Salomon E, Hutchings N, Burczyk P, Reid J (2013) An Assessment of the Variation of Manure Nitrogen Efficiency throughout Europe and an Appraisal of Means to Increase Manure-N Efficiency. Advances in Agronomy, $119,371-442$.

Whitehead, D.C. (2000) Nutrient Elements in Grassland: Soil-plant-animal Relationships. Wallingford: CABI Publishing, 369 p.

World Health Organization (WHO) (2011) Nitrate and nitrite in drinking-water (2011) Background document for development of WHO Guidelines for Drinking-water Quality. Geneva, Switzerland, World Health Organization, WHO/SDE/WSH/07.01/16/Rev/1.

Xiccato G, Schiavon S, Gallo L, Bailoni L, Bittante G (2005) Nitrogen excretion in dairy cow, beef and veal cattle, pig, and rabbit farms in Northern Italy. Italian Journal of Animal Science, 4, 103-111. 



\section{CHAPTER 3}

\section{Feed use and nitrogen excretion of livestock in}

EU-27

This Chapter has been published: Y. Hou, Z.H. Bai, J.P. Lesschen, I.G. Staritsky, N. Sikirica, L. Ma, G.L. Velthof, O. Oenema. Agriculture, Ecosystems and Environment (2016) 218: 232-244, doi:10.1016/j.agee.2015.11.025 


\title{
Chapter 3
}

\begin{abstract}
Livestock excreta is a large source of nitrogen $(\mathrm{N})$ in the European Union (EU), used to fertilize crops, and also a main source of ammonia $\left(\mathrm{NH}_{3}\right)$, nitrous oxide $\left(\mathrm{N}_{2} \mathrm{O}\right)$ and nitrate $\left(\mathrm{NO}_{3}{ }^{-}\right)$losses to the environment. The amount of $\mathrm{N}$ in excreta mainly depends on the animal category and productivity, and on feed use and management. National inventories of emissions to the environment are often based on different methodologies for the estimation of $\mathrm{N}$ excretion. Here, we present a transparent and uniform methodology for estimating annual feed use and $\mathrm{N}$ excretion per animal category for all countries of the EU-27, based on the energy and protein requirements of the animals and statistics of feed use and composition, animal number and productivity.
\end{abstract}

The calculated total feed use in the EU-27 was 506 Tg dry mass in 2010. Dairy cows used $29 \%$, other cattle $34 \%$, pigs $17 \%$, chicken $9 \%$, sheep and goats $8 \%$, and other animal categories $3 \%$ of the total feed use. Grass and annual forages were mainly used by dairy cows (30 and 49\%, respectively) and other cattle (55 and 44\%); pigs used most of the feed cereals (53\%); protein-rich feed (e.g., soybean meal) were mostly used by pigs (34\%) and chicken (24\%). Differences between countries in feed use were large, mainly related to variations in national feed supply and animal productivity. Total $\mathrm{N}$ excretion of the animals amounted to 9.7 $\mathrm{Tg}$ in 2010, and varied between countries from 14 to $291 \mathrm{~kg} \mathrm{ha}^{-1}$ of utilized agricultural land. The present study provides a uniform and transparent approach for evaluating feed use and $\mathrm{N}$ excretion in all countries of the EU-27. Our results underline the significant differences in $\mathrm{N}$ excretions between EU countries as a result of feed use variations, suggesting the need for basing $\mathrm{N}$ excretion estimations on feed use data. The dataset present in this study may serve as a basis for such efforts, also to improve national inventories of $\mathrm{N}$ emissions. 


\subsection{Introduction}

The livestock sector is a key user of natural resources, including land, water, nutrients and biomass. Recent estimates suggest that 4.7 to 7.0 billion tonnes dry biomass is used by livestock, equivalent to nearly $60 \%$ of the global plant biomass use (Krausmann et al., 2008; Wirsenius et al., 2010; Herrero et al., 2013). A similar estimate (60-65\%) is reported for Europe (Krausmann et al., 2008). The livestock sector also contributes approximately $40 \%$ to the global anthropogenic ammonia $\left(\mathrm{NH}_{3}\right)$ and nitrous oxide $\left(\mathrm{N}_{2} \mathrm{O}\right)$ emissions (Galloway et al., 2004; Oenema et al., 2005). In Europe, livestock contributes as much as $80 \%$ to the total $\mathrm{NH}_{3}$ emissions (EEA, 2014), and about $40 \%$ to the total $\mathrm{N}_{2} \mathrm{O}$ emissions (Bellarby et al., 2013; Oenema et al., 2014). In addition, over use of livestock manure results in leaching of nitrates to groundwater and surface water in Europe (Velthof et al., 2014).

Animal production is projected to continue growing in the next decades, driven by human population growth, rising incomes and dietary preferences towards 'western' diets (Steinfeld et al., 2010; Thornton, 2010). The expansion of animal production, feed use and associated environmental impacts will increase the pressures on natural ecosystems further, unless large improvements are being made in animal productivity, manure handling and manure nutrient recycling (Wirsenius et al., 2010; Kastner et al., 2012; Tilman \& Clark, 2014). Strategies such as improvements in feed quality and management, low-emission animal housing and manure management, and timing and rate of $\mathrm{N}$ application can greatly abate the growing pressure on the environment (Thornton \& Herrero, 2010; Wirsenius et al., 2010). To that end, knowledge and quantitative information on feed use and nutrient excretion rates of the animals, depending on regional resource availability, is crucial for the development of sustainable agro-ecosystems.

Feed composition and animal productivity have significant influences on nitrogen $(\mathrm{N})$ excretion, and on $\mathrm{N}$ emissions downstream in the manure management chain (Olesen et al., 2006; Oenema et al., 2009; Hou et al., 2015). International and national statistics (e.g., Eurostat and FAO statistics) provide national data on animal production and animal number per animal category annually. However, animal category-specific data on feed use and composition and on nutrient excreta are usually not available at regional or national levels, and therefore have to be collected or estimated. Various approaches are being used to estimate feed use and $\mathrm{N}$ excretion. The $\mathrm{N}$ balance approach covers both aspects of feed intake and animal production, i.e., the $\mathrm{N}$ excretion is equal to the total amount of feed $\mathrm{N}$ consumed 


\section{Chapter 3}

minus the $\mathrm{N}$ retained in animal products (e.g., milk, eggs and live-weight gains). This approach has been widely employed in field and farm scale research, and benefits from timely measured feed composition and production performance (Arriaga et al., 2010; Galassi et al., 2010; O'Connell et al., 2006; Philippe et al., 2012, 2009). Further, efforts have been made to scale up this $\mathrm{N}$ balance approach to regional and national scales, based on estimates of regional and category specific feed use, to support national inventories of $\mathrm{N}$ emissions (Webb, 2001; Velthof et al., 2012; Bai et al., 2014). Most of these national-level studies have focused on a single animal category. However, only national studies that include all animal categories would allow to check the feed balance; do the total supplies of feed resources in a country indeed match with the sum of the estimated national feed use by all animal categories, within acceptable ranges of uncertainty?

The overall objective of our study was to provide a uniform approach for the estimation of feed use and $\mathrm{N}$ excretion rates of the animals in EU-27 through linking statistical data on feed quality and quantity with energy and protein requirements per animal category at country levels. Firstly, we developed a uniform method for the estimation of animal category-specific average feed use per country, as function of animal productivity and feed availability. Secondly, we estimated the $\mathrm{N}$ excretion rates of individual animal categories using the $\mathrm{N}$ balance approach. Thirdly, sensitivity analyses were carried out to get quantitative insight in the effect of changes of several methodological parameters on the feed use and $\mathrm{N}$ excretion. We then discussed regional variations in feed use and $\mathrm{N}$ excretion, and compared our results with national inventories, and also discussed the implication of our study.

\subsection{Materials and methods}

\subsubsection{Concept}

The methodology developed here aims at deriving animal category-specific and countryspecific $\mathrm{N}$ excretion coefficients through linking statistical data and information on the availability (quantity and quality) of feed with animal numbers, and the energy and protein requirements of the animals. Animal categories included dairy cows, other cattle, sheep and goats, pigs, laying hens, broilers, turkey and other poultry, i.e., similar to the main categories in the Farm Structure Survey (FFS), used by all countries of the EU-27. The methodology developed in this study is described schematically in Figure 3-1. We started by estimating the feed energy required for each animal category per country, considering animal stock and 
animal production (e.g., milk, eggs and meat). Next, national feed supply and compositions were derived for eight aggregated feed classes: (i) animal and fish derived feed, (ii) proteinrich feed (e.g., soybean meal), (iii) cereal (grain or processed) feed, (iv) brans, (v) oil and sugar crops, (vi) other non-roughage feed (e.g., root crops, and residues of fruits and vegetables), (vii) annual forages (e.g., maize silage, leguminous crops, temporary grass, and crop straw) and (viii) perennial forages (grass harvested by grazing and grass harvested for silage and hay). We then partitioned each feed aggregate over animal categories using a linear optimization approach, by respecting a series of category-specific numerical constraints related to energy and protein requirements, with the objective of minimizing the difference between the total feed biomass supply and the total feed biomass requirements per country. Finally, we quantified $\mathrm{N}$ excretion as the difference between the feed $\mathrm{N}$ intake (i.e., $\mathrm{N}$ in animal diet) and the $\mathrm{N}$ retained in animal products for each animal category on the national scale. We based our data on three-year averages of statistical input data (e.g., animal stock, production, and feed biomass supply and production) for the period 2009-2011. The calculation procedures are described in more detail in the following sections.

\subsubsection{Calculation of energy requirements}

The total annual energy requirement of each ruminant category (dairy cows, other cattle, sheep and goats) was estimated per country according to the Tier 2 approach of IPCC (2006). The method described by Wirsenius (2000) was adapted here to calculate the energy requirements of the mono-gastric animal categories. Energy requirements were calculated for animal maintenance, growth, lactation, pregnancy and activity, as a function of the average live weight of the animals, animal production and management conditions (i.e., raised in houses or pasture) (IPCC, 2006; Wirsenius, 2000). Energy requirements for maintenance were based on the number of animals in the statistics and the calculated requirement per animal on a national level. We assumed that the number of animals remained constant throughout the year. Energy requirements for growth, lactation and pregnancy were related to animal production statistical data. Information about pasturing periods of ruminants was derived from national inventory reports to UNFCCC (the United Nations Framework Convention on Climate Change) and used for calculation of energy requirements for activity (IPCC 2006). More details about the calculations of energy requirements can be found in the supplementary information. Animal numbers and production data were derived from Eurostat (2014). Energy required by ruminants was calculated on a digestible energy (DE) basis. For poultry and pigs, 


\section{Chapter 3}

the calculated energy requirements are expressed as metabolizable energy (ME) and digestible energy (DE), respectively.

All calculations were performed with GAMS programming software (http://www.gams.com/). Linear optimization was performed using the 'LP' solver in GAMS.

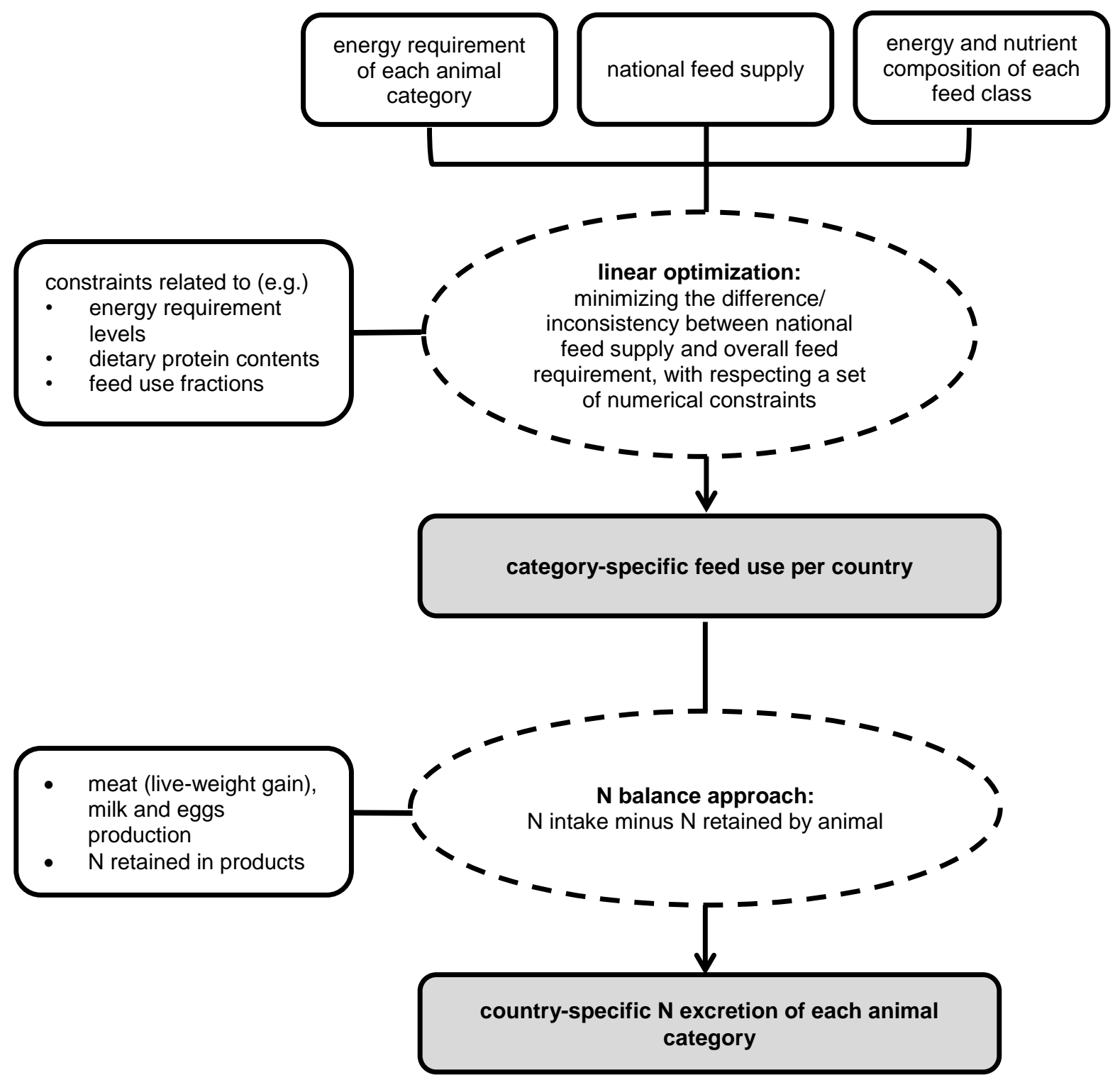

Figure 3-1. A simplified schematic representation of the information flow in calculating countryspecific feed use and nitrogen $(\mathrm{N})$ excretion of each animal category. The arrows depict the information flow direction. Information as data and parameter input to the model are sketched in top and left boxes. Results are indicated in the shaded boxes, which are gained through the calculations indicated in dashed circles. 


\subsubsection{Calculation of feed supply}

Data on the national supply of feed resources (except for grass, forages and crop residues) were extracted from FAO commodity balance sheets; data were corrected for export and import (FAOSTAT, 2014). The fresh or air-dry weights in the FAOSTAT database were corrected for moisture content to obtain a uniform dry matter (DM) weight of each feed item. The use of straw as feedstuff was based on domestic cereal production (FAOSTAT), the mean straw/grain ratio (Krausmann et al., 2008) and the proportion of crop straw recovered as feed (Krausmann et al., 2008). The supplies of grass and annual forages were estimated from the land areas of grassland and forages (Eurostat, 2014), multiplied by the regional productivity data of forages (Eurostat, 2014) and grass (Smit et al., 2008).

The specific feed resources present in FAO commodity balance sheets and the grass, forages and straw were aggregated into 20 groups. Parameters related to protein and energy contents were given for each feed group (Table S3 and Table S4). Protein and energy contents were obtained from NRC $(2001,2000,1998,1994)$. The supply of feed protein and energy were estimated for each feed group and each country. To improve the optimization procedure (see Section 3.2.4) and the presentation of results, we further allocated these 20 feed groups into eight main classes (animal and fish derived feed, protein-rich feed, cereal feed, brans, oil-andsugar crops, other non-roughage feed, annual forages and perennial forages). The classification of feedstuffs is further detailed in the supplementary information.

\subsubsection{Feed allocation}

The allocation of feed classes over animal categories per country in EU-27 was performed by an optimization procedure and under a set of constraints, dependent on the protein and energy requirements per animal category per country and the availability of national feed resources. The final objective of the optimization is to minimize the difference between the total national feed biomass supply (see Section 3.2.3) and the calculated total feed biomass use by all animal categories in a country. The feed biomass use (feed ration) of the animal was determined endogenously by the feed optimization model, and therefore considered an outcome of the model calculations. The principle behind this minimization objective is that the total national feed supply has to match with the total feed use, within acceptable ranges of uncertainty. We assumed that the feed biomass supply can be equal to or more than the 


\section{Chapter 3}

calculated feed biomass use. Four constraints were considered, as follows (see also supplementary information):

1. We estimated the energy requirement per animal category for 'average' conditions in a country (e.g., average climate, animal genetics and animal performance; Section 3.2.2). To allow for some variations, we assumed that the 'actual' energy requirement may vary from 90 to $110 \%$ of the requirement for 'average' conditions. Therefore, the feed energy use per animal category (endogenous variable of the model) was considered equal to the calculated energy requirement for 'average conditions' within a range of \pm $10 \%$.

2. The average crude protein (CP) contents of the animal diets were constrained by a set of category-specific ranges derived from literature (e.g., Bittman et al., 2014) (see Table 3-1). Please note that the ranges of dietary CP contents were the estimates for national average conditions; there may be animal farms in practice where the $\mathrm{CP}$ contents in animal diets may be higher (or lower) than the upper (or lower) value of the range, but these farms are not representative of national averages.

3. Roughage (grass, forages and crop residues) were allocated to ruminants, cereals and protein-rich feeds were offered mainly to poultry and pigs. Table 3-1 summarizes these constraints, which were defined according to literature (Bouwman et al., 2005; Lesschen et al., 2011; CBS, 2012) and experts' opinions.

4. We assumed that all animals in one country use at least $85 \%$ of the supply of highquality feed classes, such as protein-rich feed and feed cereals, and at least $70 \%$ of the total supply of animal and fish derived feed, brans, root and sugar crops and grass from managed grassland. The minimum percentages of feed use were set relatively low for annual forages (at least $40 \%$ of the supply), other non-roughage feeds (e.g., root crops, residues of fruits and vegetables) in minute supply (20\%), natural grass (10\%) and crop residues (10\%). These assumptions are set up mainly for the sake of proper methodological performances and uncertainty concerns (discussed in detail in Section 3.4.2). For instance, by setting the minimum use of major feed classes high, we guarantee that animals make full use of these high-quality feeds as much as possible. Feedstuffs from crop residues are known to be insignificant in animal diets (in most EU countries), thus low priority for their use were assumed by using a low minimum percentage. In addition, uncertainties in the estimated supply of annual forages, crop residues and natural grasses are relatively large, so that low minima were 
assigned. It should be noted that the calculated feed use of these low-quality (and minute-supply) feed classes may be large as percentage of the feed supply, when the high-quality feed classes in a country are hardly sufficient to meet the total feed requirements of the animals.

\subsubsection{Calculation of nitrogen excretion}

Nitrogen excretion of each animal category at the national level was quantified as the difference between the total feed $\mathrm{N}$ intake and the total $\mathrm{N}$ retained by animal products (milk, eggs and/or live-weight gains). Feed $\mathrm{N}$ intake per animal category was quantified based on individual feed DM intake per animal category and $\mathrm{N}$ content of the respective feedstuff. The $\mathrm{N}$ retained in animal products per animal category was calculated according to the total production of animal products per animal category and $\mathrm{N}$ contents of the products. Nitrogen content is expressed in $\% \mathrm{~N}$ of DM in the case of feed and in \% of fresh weight (as-is) in the case of animal products. Nitrogen and crude protein contents were assumed to be related by a constant protein-to-nitrogen coefficient. Country-specific protein contents of dairy milk were derived from Eurostat (three-year averages over 2009-2011), then converted to N contents using a constant milk protein-to-nitrogen conversion coefficient. Protein contents in other animal products are not recorded by Eurostat; therefore, $\mathrm{N}$ contents (\% N, on as-is basis) were derived from literature and were uniformly applied to all countries: i.e., $0.5 \%$ for goat and sheep milk, $1.85 \%$ for eggs, $2.5 \%$ for live-weight gains of sheep, goat and pigs, $3.0 \%$ for live-weight gains of chicken, $3.1 \%$ for turkey and $2.6 \%$ for other cattle and other poultry (CBS, 2012). 


\section{Chapter 3}

Table 3-1. Constraints added to the linear equations of feed partitioning, applied uniformly to all EU-27 countries (unless otherwise noted).

\begin{tabular}{|c|c|c|c|c|c|c|c|c|c|c|c|}
\hline \multirow{3}{*}{$\begin{array}{l}\text { Animal } \\
\text { categories }\end{array}$} & \multirow[t]{3}{*}{ Ranges } & \multirow{3}{*}{$\begin{array}{l}\text { Constraints of } \\
\text { crude protein } \\
\text { content in diet } \\
(\%, \text { in weight })\end{array}$} & \multicolumn{9}{|c|}{ Constraints related to the fraction of each feed class in diet (on dry matter basis) } \\
\hline & & & \multirow{2}{*}{$\begin{array}{l}\text { Animal and } \\
\text { fish based } \\
\text { feed }\end{array}$} & \multirow{2}{*}{$\begin{array}{l}\text { Protein- } \\
\text { rich feed }\end{array}$} & \multirow[t]{2}{*}{ Cereals $^{\mathrm{a}}$} & \multirow[t]{2}{*}{ Brans } & \multirow{2}{*}{$\begin{array}{l}\text { Oil and } \\
\text { sugar } \\
\text { crops }\end{array}$} & \multirow[t]{2}{*}{ Others } & \multirow[t]{2}{*}{ Grass $^{\mathrm{a}}$} & \multicolumn{2}{|c|}{ Annual forages } \\
\hline & & & & & & & & & & $\begin{array}{l}\text { Maize and } \\
\text { other forages }\end{array}$ & crop straw \\
\hline \multirow[t]{2}{*}{ Dairy cows } & Min. & 13 & 0 & 0.05 & 0.05 & 0 & 0 & 0 & 0.20 & 0.05 & 0 \\
\hline & Max. & 19 & 0.10 & 0.10 & 0.40 & 0.10 & 0.25 & 0.25 & 0.95 & 0.60 & 0.10 \\
\hline \multirow[t]{2}{*}{ Other cattle } & Min. & 13 & 0 & 0 & 0 & 0 & 0 & 0 & 0.20 & 0.05 & 0 \\
\hline & Max. & 19 & 0.10 & 0.10 & 0.40 & 0.10 & 0.25 & 0.25 & 0.95 & 0.60 & 0.10 \\
\hline \multirow[t]{2}{*}{ Sheep } & Min. & 14 & 0 & 0 & 0 & 0 & 0 & 0 & 0.20 & 0.05 & 0 \\
\hline & Max. & 19 & 0.10 & 0.05 & 0.15 & 0.10 & 0.25 & 0.25 & 0.95 & 0.60 & 0.10 \\
\hline \multirow[t]{2}{*}{ Goats } & Min. & 14 & 0 & 0 & 0 & 0 & 0 & 0 & 0.20 & 0.05 & 0 \\
\hline & Max. & 20 & 0.10 & 0.05 & 0.30 & 0.10 & 0.25 & 0.25 & 0.95 & 0.60 & 0.10 \\
\hline \multirow[t]{2}{*}{ Pigs } & Min. & 14 & 0 & 0.05 & 0 & 0 & 0 & 0 & - & - & - \\
\hline & Max. & 18 & 0.10 & 0.40 & 0.85 & 0.30 & 0.15 & 0.15 & - & - & - \\
\hline \multirow[t]{2}{*}{ Laying hens } & Min. & 15 & 0 & 0.15 & 0 & 0 & 0 & 0 & - & - & - \\
\hline & Max. & 18 & 0.10 & 0.55 & 0.80 & 0.25 & 0.15 & 0.15 & - & - & - \\
\hline \multirow[t]{2}{*}{ Broilers } & Min. & 17 & 0 & 0.20 & 0 & 0 & 0 & 0 & - & - & - \\
\hline & Max. & 20 & 0.10 & 0.55 & 0.80 & 0.25 & 0.15 & 0.15 & - & - & - \\
\hline \multirow[t]{2}{*}{ Turkey } & Min. & 14 & 0 & 0.20 & 0 & 0 & 0 & 0 & - & - & - \\
\hline & Max. & 21 & 0.10 & 0.55 & 0.80 & 0.25 & 0.15 & 0.15 & - & - & - \\
\hline \multirow{2}{*}{$\begin{array}{l}\text { Other poultry } \\
\text { (duck and } \\
\text { geese) }\end{array}$} & Min. & 14 & 0 & 0.15 & 0 & 0 & 0 & 0 & - & - & - \\
\hline & Max. & 20 & 0.10 & 0.55 & 0.80 & 0.25 & 0.15 & 0.15 & - & - & - \\
\hline
\end{tabular}

- Not applicable.

${ }^{a}$ The maximum constraints of cereal product fractions for ruminants were adjusted into 0.4 for Cyprus and Malta, and the minimum constraints of grass fractions were 0.1 for Cyprus, Malta and Finland; these adjustment are made considering the relatively small fraction of grass supply in these countries. 


\subsubsection{Definition of assessment indicators}

Feed conversion was defined as the amount of dry weight feed needed to produce $1 \mathrm{~kg}$ of animal product. Feed conversion ratio (FCR) was calculated by dividing the overall feed dry mass intake by the total production of animal products per animal category per country. Further, feed energy to edible energy convention ratio (FER), i.e., the feed energy intake needed to yield $1 \mathrm{MJ}$ edible energy contained in animal products, was quantified. Edible energy contents in animal products were derived from USDA (2011). The feed-to-animal protein conversion ratio (FPR), i.e., the feed dry mass needed to yield $1 \mathrm{~kg}$ protein in animal product, was also calculated. Nitrogen use efficiency (NUE, \%) at animal level was quantified in terms of total $\mathrm{N}$ retained in animal production as percentage of total feed $\mathrm{N}$ intake. In addition, the mean feed DM ( $\mathrm{kg} \mathrm{DM}$ stock $\left.^{-1} \mathrm{yr}^{-1}\right)$, energy $\left(\mathrm{MJ}\right.$ stock $\left.^{-1} \mathrm{yr}^{-1}\right)$ and $\mathrm{N}$ intake $(\mathrm{kg} \mathrm{N}$ stock $^{-1} \mathrm{yr}^{-1}$ ) per animal stock, and the $\mathrm{N}$ retained and $\mathrm{N}$ excretion ( $\mathrm{N}$ excretion coefficient) per animal stock were calculated. The number of animals (stock) were derived from Eurostat (three-year averages were used, namely 2009-2011). Data were checked for consistency through comparing the number and mean weight of slaughtered animals with the mean stock; we observed for some countries (e.g., Slovenia) unusually high values for the ratio of slaughtered broilers to the mean stock of broilers. Stock data were corrected in such cases by using the median ratio of slaughtered number to stock in the EU-27.

\subsubsection{Sensitivity analyses}

The impacts of changes of input parameters on total feed use and $\mathrm{N}$ excretion per country were assessed, so as to identify the sensitivity of assumptions and input parameters:

- The $\mathrm{N}$ concentration of feed may vary due to the variations in, e.g., fertilization, crop varieties and climate conditions. The effect of these possible variations on the total feed use and $\mathrm{N}$ excretion were assessed for major feed classes, namely, protein-rich feed $( \pm 5 \%$, relative to default $\mathrm{N}$ content), cereals $( \pm 10 \%)$ and grass $( \pm 10 \%)$. According to the literature (Feedipedia, 2014; NRC, 2001), generally regional variations in protein contents of grass and cereals were larger than that of protein-rich feed (e.g., soybean and soybean meal, and other oil cakes).

- Effects of possible variations in feed energy content on feed use and the amount of $\mathrm{N}$ in excreta per country were estimated by assuming a 5\% difference in energy content, compared to the default energy content, for cereal feed and grass. This assumption for 
the changes $( \pm 5 \%)$ in energy content was based on literature information (Feedipedia, 2014; NRC, 2001) and experts' opinions.

- Effects of possible variations in animal production and animal numbers on total national feed use and $\mathrm{N}$ excretion were also examined: i) increases in animal production by $5 \%$, with animal numbers being unchanged (i.e., increasing animal productivity); ii) increases in both animal production and animal numbers by $5 \%$ (i.e., expanding animal husbandry with the default animal productivity level).

- Effects of changes $( \pm 5 \%)$ in average live weight of animals, relative to the default value, on total feed use and $\mathrm{N}$ excretion per country were analysed.

\subsection{Results}

\subsubsection{Feed supply and use}

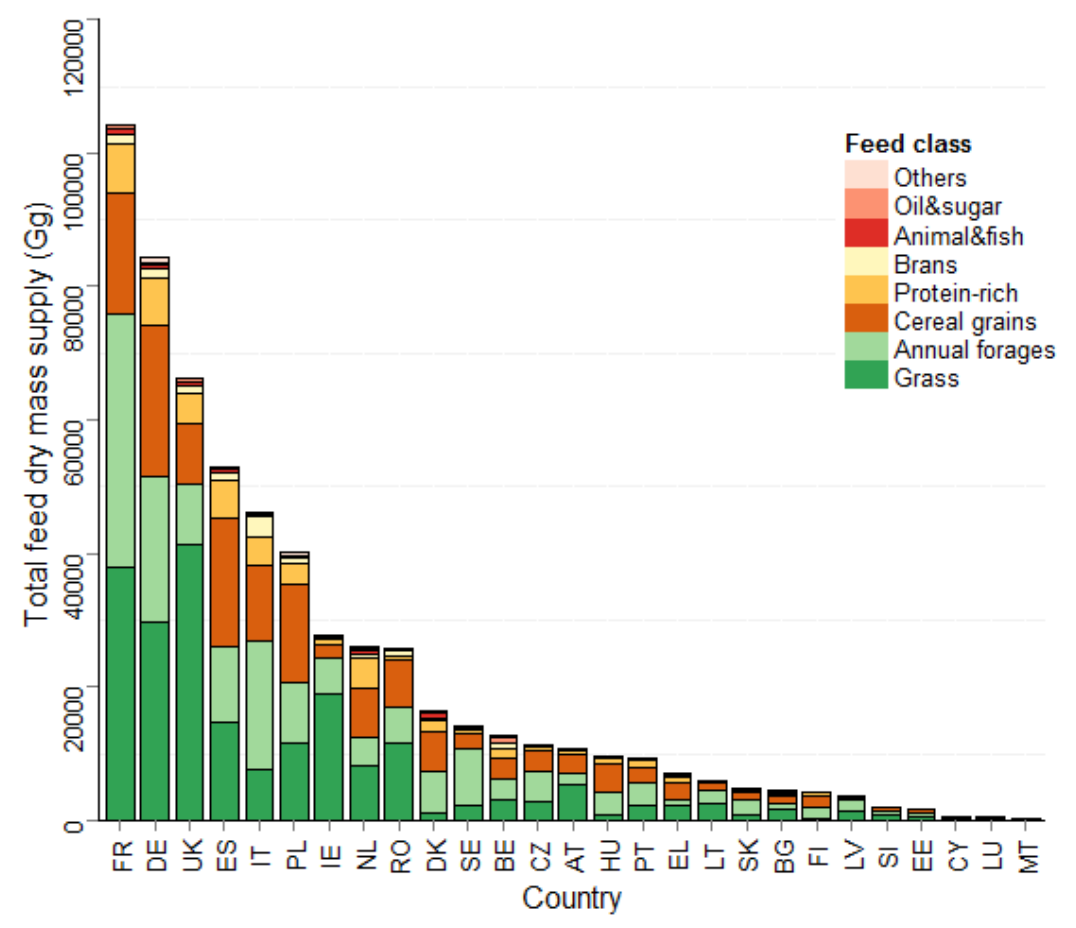

Figure 3-2. The total supply of dry-weight mass per feed class per country of the EU-27, annual averages of 2009-2011 ( $\left.\mathrm{Gg}=10^{9} \mathrm{~g}\right)$. Country abbreviations are explicated in Table 3-2. 
Figure 3-2 shows the estimated three-year averaged (2009-2011) feed supply per feed class per country in the EU-27. The total feed supply in the EU-27 amounted to $593 \mathrm{Tg}(1 \mathrm{Tg}=$ $10^{12} \mathrm{~g}$ ). Feed supply ranged from $<1 \mathrm{Tg} \mathrm{yr}^{-1}$ in Cyprus, Luxembourg and Malta to $>50{\mathrm{Tg} \mathrm{yr}^{-1}}^{-1}$ in France, Germany, Spain and the UK. Grass, annual forages (e.g., silage maize, leguminous crops) and cereals were the largest feed classes, accounting for 33, 28 and $25 \%$ of the total feed use in the EU-27, respectively. However, there were large differences between countries (Figure 3-2). The calculated total feed use was $506 \mathrm{Tg}$, or $85 \%$ of the calculated feed supply in the EU-27; the use of cereal feed and protein-rich feed was on average $90 \%$ of their supply totals (see Table S5). Note that effects of feed wastes and conservation losses were not included in the feed use estimations due to the lack of reliable quantitative information.

The annual average feed DM use per animal category in EU-27 was $6252 \mathrm{~kg}$ for dairy cows, $2620 \mathrm{~kg}$ for other cattle, $571 \mathrm{~kg}$ for pigs, $359 \mathrm{~kg}$ for sheep and goats, $35 \mathrm{~kg}$ for laying hens, and $38 \mathrm{~kg}$ for broilers. There were large variations between countries, both in the feed use per animal and the feed composition (Figure 3-3). The average ration of dairy cows comprised $34 \%$ perennial forages, $48 \%$ annual forages and $17 \%$ cereals and protein-rich feed; other cattle used 54, 37 and $8 \%$ of the aforementioned feed classes, respectively. Grass was the main ingredient for cattle in countries with large areas of grassland, e.g., Germany, Netherlands, Ireland and the UK (Figure 3-3). Cereals, protein-rich feed and brans were the main feed sources for pigs (on average 78, 17 and $4 \%$ of the ration, respectively), laying hens (72, 19 and $6 \%)$ and broilers (47, 24 and 18\%).

Dairy cows used $29 \%$ of the total feed use in the EU-27, other cattle used 34\%, pigs $17 \%$ and chicken 9\% (Table S6). Pigs used 53\%, chicken 21\%, and dairy cows $14 \%$ of the cereal feed in EU. Protein-rich feed was used for $34 \%$ by pigs, $24 \%$ by chicken, $18 \%$ by dairy cows, and for $14 \%$ by other cattle (Table S7). The feed use per animal category per country is shown in Figure 3-4. Dairy cows and other cattle had the largest share in the national total feed use, except for Denmark and Spain, where pigs had the largest share. 


\section{Chapter 3}
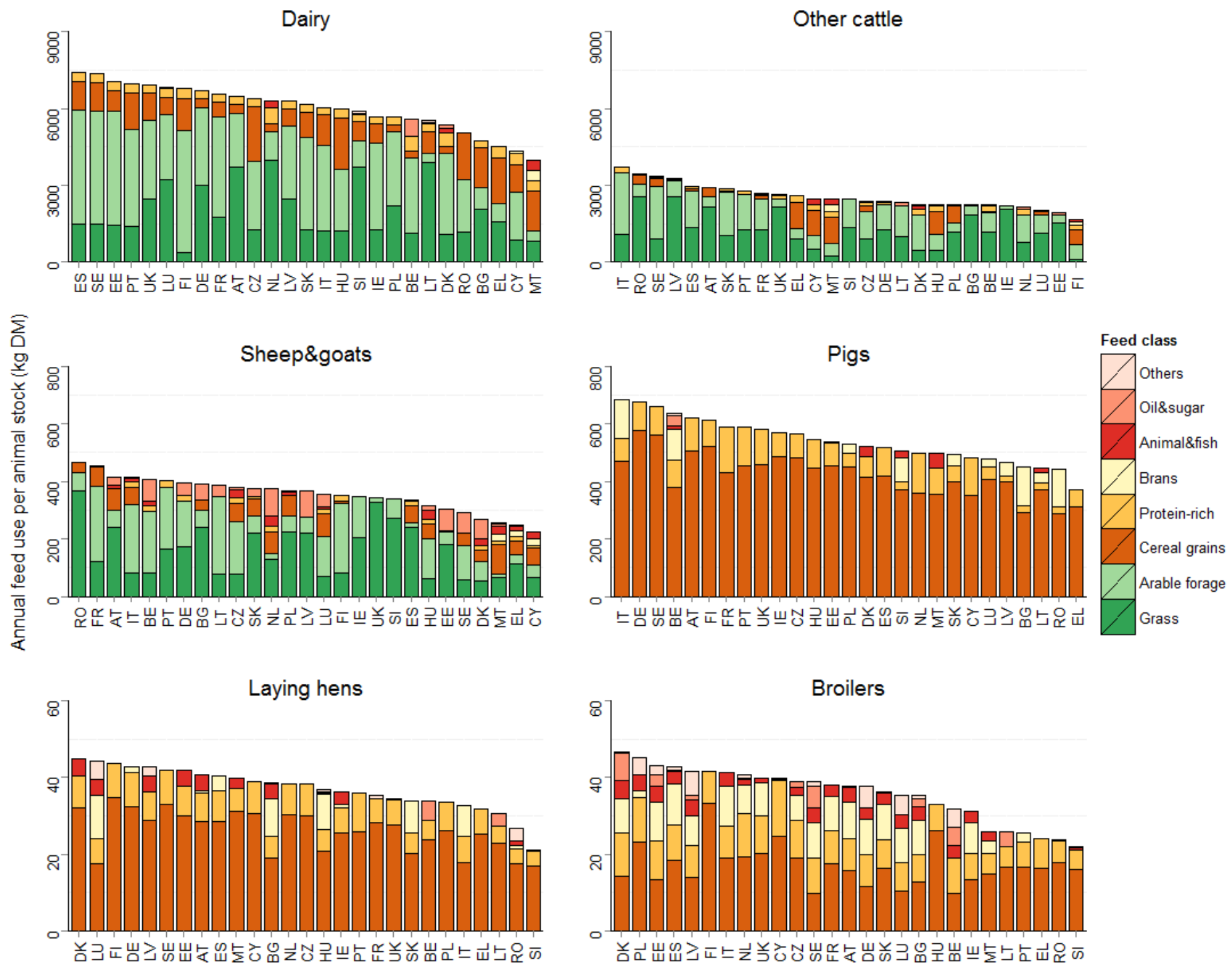

Country

Figure 3-3. Annual average feed dry matter (DM) use per animal stock of the main livestock categories in the EU-27. Notice that member states on $\mathrm{X}$-axis are presented in decreasing order. Country abbreviations are explicated in Table 3-2. 

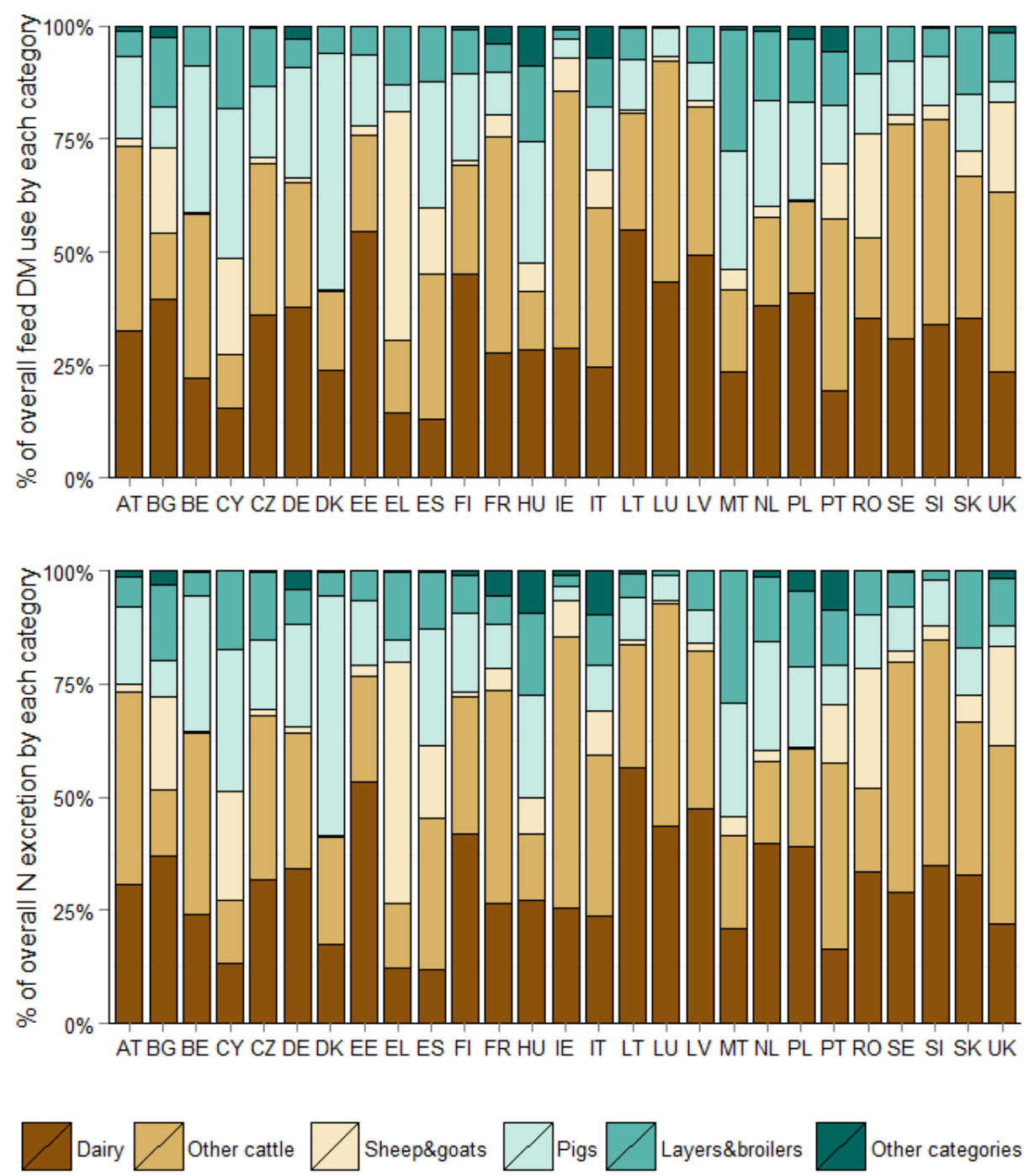

Figure 3-4. Percentage of national total feed dry matter (DM) use by animal category and percentage of total nitrogen $(\mathrm{N})$ excretion by animal category for each country in the EU- 27. Country abbreviations are explicated in Table 3-2.

\subsubsection{Feed nitrogen intake}

Total feed $\mathrm{N}$ intake of all animal categories in EU-27 was estimated at $12.2 \mathrm{Tg}$ for the threeyear average of 2009-2011. The calculated feed $\mathrm{N}$ intake per head for each animal category and each country is shown in Figure 3-5. The annual average $\mathrm{N}$ intake in kg per head was 144 $\mathrm{kg}$ for dairy cows (range 94-185 kg), $58 \mathrm{~kg}$ for other cattle (42-84 kg), $15 \mathrm{~kg}$ for pigs (9-17 $\mathrm{kg}), 8 \mathrm{~kg}$ for sheep and goats $(5-15 \mathrm{~kg}), 1.0 \mathrm{~kg}$ for laying hens $(0.5-1.3 \mathrm{~kg})$ and $1.2 \mathrm{~kg}$ for broilers $(0.6-1.5 \mathrm{~kg})$ in the EU-27. For ruminants, protein-N intake mainly originated from perennial (grasses) and annual forages (Figure 3-5). Protein-rich feed and cereals were the main protein-N sources of pigs, laying hens and broilers (Figure 3-5). 


\section{Chapter 3}
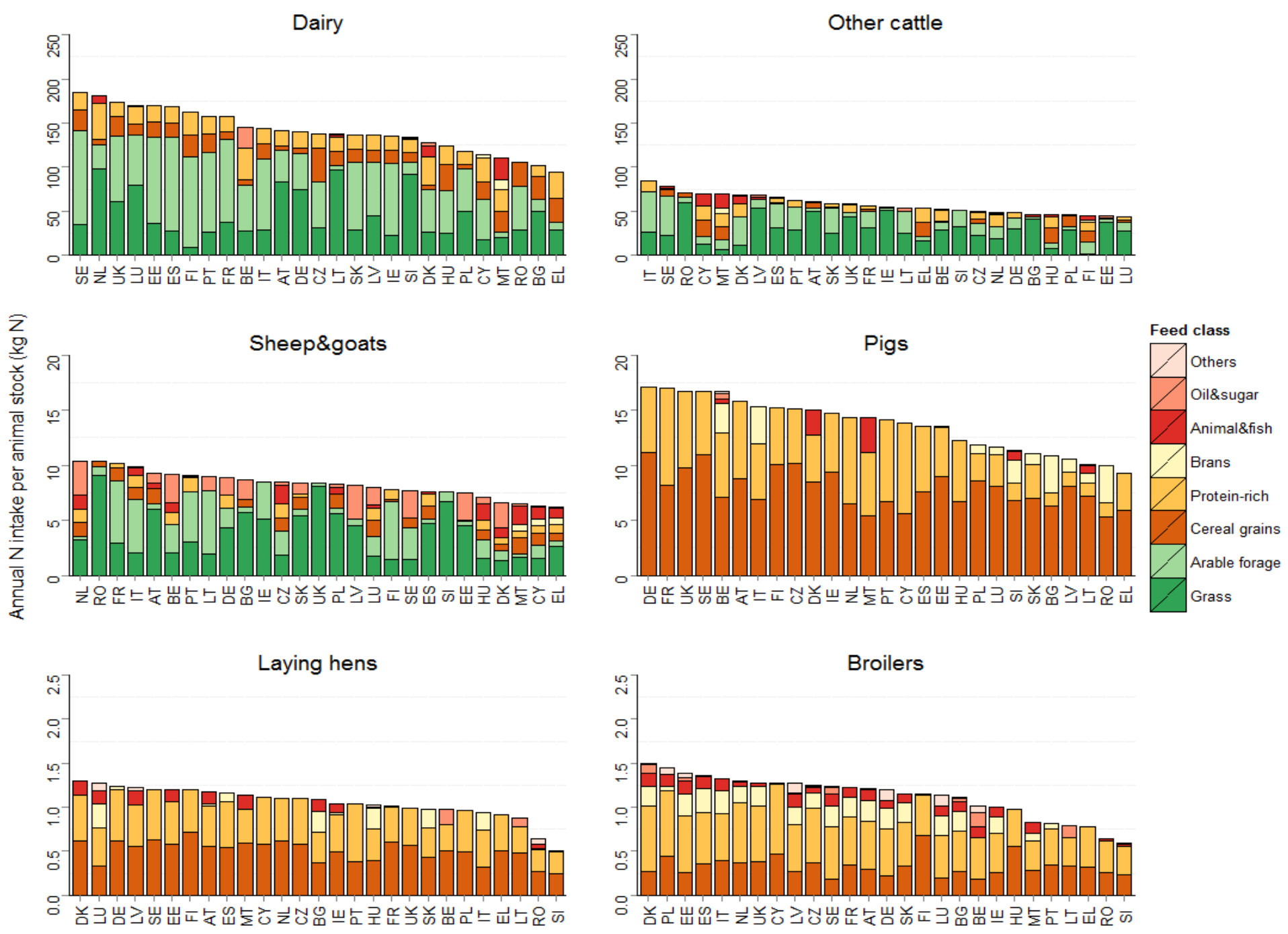

Figure 3-5. Annual average feed nitrogen $(\mathrm{N})$ intake per animal stock per country for the main livestock categories in the EU-27. Notice that member states on $\mathrm{X}$-axis are presented in decreasing order. Country abbreviations are explicated in Table 3-2. 


\subsubsection{Nitrogen excretion}

The total amount of $\mathrm{N}$ excreted by animals in the EU-27 was $9.7 \mathrm{Tg}^{-1} \mathrm{yr}^{-1}$ for the period 20092011 (Table 3-2). Dairy cows contributed 27\%, other cattle 35\%, pigs 15\%, chicken (i.e., layers and broilers) 10\%, sheep and goats 9\% (Table 3-2). Countries with the largest total $\mathrm{N}$ excretions were France and Germany, followed by UK, Italy, Spain, Poland and The Netherlands. The average annual $\mathrm{N}$ excretion per ha of utilized agricultural land (UAA) in the EU-27 was $54 \mathrm{~kg} \mathrm{ha}^{-1}$, ranging from $<25 \mathrm{~kg} \mathrm{ha}^{-1}$ in Bulgaria and Latvia to more than $170 \mathrm{~kg}$ ha $^{-1}$ in Belgium and The Netherlands (Table 3-2).

Table 3-2. Total nitrogen $(\mathrm{N})$ excretion per animal category and per country $\left(\mathrm{Gg} \mathrm{N} \mathrm{yr}^{-1}\right)$ and $\mathrm{N}$ excretion per ha of utilized agricultural land $\left(\mathrm{kg} \mathrm{N} \mathrm{ha}^{-1} \mathrm{UAA}\right)$ in the EU-27 $\left(1 \mathrm{Gg}=10^{9} \mathrm{~g}\right)$.

\begin{tabular}{|c|c|c|c|c|c|c|c|c|c|}
\hline \multirow{2}{*}{$\begin{array}{l}\text { Country names } \\
\text { (abbreviations) }\end{array}$} & \multicolumn{6}{|c|}{$\mathrm{N}$ excretion $\left(\mathrm{Gg} \mathrm{N} \mathrm{yr}^{-1}\right)$} & \multirow{2}{*}{$\begin{array}{l}\text { National } \\
\text { sum } \\
(\mathrm{Gg} \mathrm{N} \mathrm{N} \\
\left.\mathrm{yr}^{-1}\right)\end{array}$} & \multirow{2}{*}{$\begin{array}{l}\text { National } \\
\text { sum as \% } \\
\text { of EU-27 } \\
\text { totals }\end{array}$} & \multirow{2}{*}{$\begin{array}{l}\text { N excretion } \\
\text { per ha }(\mathrm{kg} \\
\mathrm{N} \mathrm{ha}^{-1} \\
\text { UAA) }{ }^{\text {a }}\end{array}$} \\
\hline & $\begin{array}{l}\text { Dairy } \\
\text { cows }\end{array}$ & $\begin{array}{l}\text { Other } \\
\text { cattle }\end{array}$ & Pigs & Chicken & $\begin{array}{l}\text { Sheep } \\
\text { \&Goats }\end{array}$ & Others & & & \\
\hline Austria (AT) & 57 & 80 & 32 & 12 & 3 & 2 & 177 & 2 & 61 \\
\hline Belgium (BE) & 57 & 95 & 71 & 13 & 1 & $<1$ & 238 & 2 & 176 \\
\hline Bulgaria (BG) & 26 & 10 & 6 & 12 & 14 & 2 & 68 & 1 & 14 \\
\hline Cyprus (CY) & 2 & 2 & 4 & 2 & 3 & - & 14 & $<0.5$ & 121 \\
\hline Czech $(\mathrm{CZ})$ & 39 & 45 & 19 & 18 & 2 & $<1$ & 117 & 1 & 35 \\
\hline Denmark (DK) & 46 & 62 & 138 & 15 & $<1$ & $<1$ & 256 & 3 & 98 \\
\hline Estonia (EE) & 13 & 6 & 3 & 2 & $<1$ & - & 26 & $<0.5$ & 26 \\
\hline Finland (FI) & 34 & 25 & 14 & 7 & $<1$ & $<1$ & 84 & 1 & 36 \\
\hline France (FR) & 457 & 819 & 169 & 108 & 84 & 93 & 1563 & 18 & 56 \\
\hline Germany (DE) & 424 & 367 & 280 & 95 & 19 & 50 & 1309 & 13 & 74 \\
\hline Greece (EL) & 16 & 20 & 7 & 20 & 73 & $<1$ & 136 & 1 & 35 \\
\hline Hungary (HU) & 30 & 17 & 25 & 20 & 9 & 11 & 106 & 1 & 20 \\
\hline Ireland (IE) & 120 & 281 & 15 & 10 & 38 & 5 & 454 & 5 & 106 \\
\hline Italy (IT) & 208 & 309 & 88 & 98 & 84 & 83 & 848 & 9 & 67 \\
\hline Latvia (LV) & 18 & 14 & 3 & 3 & $<1$ & - & 35 & $<0.5$ & 21 \\
\hline Lithuania (LT) & 41 & 20 & 7 & 4 & $<1$ & $<1$ & 72 & 1 & 26 \\
\hline Luxembourg (LU) & 5 & 6 & $<1$ & $<1$ & $<1$ & - & 12 & $<0.5$ & 94 \\
\hline Malta (MT) & $<1$ & $<1$ & $<1$ & $<1$ & $<1$ & $<1$ & 3 & $<0.5$ & 226 \\
\hline Netherlands (NL) & 219 & 98 & 133 & 78 & 14 & 7 & 553 & 6 & 291 \\
\hline Poland (PL) & 237 & 130 & 109 & 100 & 3 & 28 & 646 & 6 & 40 \\
\hline Portugal (PT) & 29 & 72 & 15 & 22 & 23 & 15 & 152 & 2 & 48 \\
\hline Romania (RO) & 121 & 66 & 43 & 34 & 96 & - & 291 & 4 & 26 \\
\hline Slovakia (SK) & 17 & 18 & 5 & 9 & 3 & - & 45 & 1 & 28 \\
\hline Slovenia (SI) & 12 & 17 & 3 & $<1$ & 1 & $<1$ & 32 & $<0.5$ & 71 \\
\hline Spain (ES) & 109 & 310 & 239 & 117 & 150 & 3 & 830 & 10 & 39 \\
\hline Sweden (SE) & 49 & 86 & 17 & 13 & 4 & $<1$ & 141 & 2 & 55 \\
\hline $\begin{array}{l}\text { United Kingdom } \\
\text { (UK) }\end{array}$ & 250 & 445 & 50 & 119 & 249 & 18 & 1012 & 12 & 66 \\
\hline Sum of EU-27 & 2636 & 3419 & 1498 & 932 & 877 & 320 & 9681 & 100 & 54 \\
\hline
\end{tabular}

- Not considered or no available data.

${ }^{\mathrm{a}}$ The total utilized agricultural area (UAA) were derived from Eurostat (three-year averages of 2009-2011). 


\section{Chapter 3}

Country- and animal- specific $\mathrm{N}$ excretion coefficients expressed in $\mathrm{kg} \mathrm{N}$ per animal per year are presented in Table 3-3. Differences in $\mathrm{N}$ excretion coefficients between countries were large. The average $\mathrm{N}$ excretion coefficients were $111 \mathrm{~kg}$ for dairy cows (range 75-141 kg), 52 $\mathrm{kg}$ for other cattle $(39-73 \mathrm{~kg}), 9.9 \mathrm{~kg}$ for pigs $(6-12 \mathrm{~kg}), 0.74 \mathrm{~kg}$ for laying hens $(0.25-0.95 \mathrm{~kg})$, $0.73 \mathrm{~kg}$ for broilers $(0.15-0.92 \mathrm{~kg}), 8 \mathrm{~kg}$ for sheep $(6-10 \mathrm{~kg})$ and about $7 \mathrm{~kg}$ for goats $(4-12 \mathrm{~kg})$ in the EU-27.

Table 3-3. Country-specific nitrogen $(\mathrm{N})$ excretion coefficients of the main animal categories in the EU-27 (kg N animal $\left.{ }^{-1} \mathrm{yr}^{-1}\right)$.

\begin{tabular}{|c|c|c|c|c|c|c|c|c|c|}
\hline \multirow{2}{*}{ Country } & \multicolumn{9}{|c|}{$\mathrm{N}$ excretion coefficient $\left(\mathrm{kg} \mathrm{N}\right.$ animal $\left.{ }^{-1} \mathrm{yr}^{-1}\right)$} \\
\hline & $\begin{array}{l}\text { Dairy } \\
\text { cows }\end{array}$ & $\begin{array}{l}\text { Other } \\
\text { cattle }\end{array}$ & Pigs & $\begin{array}{r}\text { Laying } \\
\text { hens }\end{array}$ & Broilers & Sheep & Goats & Turkey & $\begin{array}{r}\text { Other } \\
\text { poultry }\end{array}$ \\
\hline Austria & 107 & 54 & 10.1 & 0.86 & 0.77 & 8.1 & 8.5 & 3.9 & 0.8 \\
\hline Belgium & 113 & 46 & 11.1 & 0.65 & 0.26 & 7.6 & 10.7 & 1.5 & - \\
\hline Bulgaria & 83 & 42 & 7.6 & 0.86 & 0.69 & 8.1 & 7.2 & - & 1.1 \\
\hline Cyprus & 79 & 63 & 9.8 & 0.83 & 0.83 & 6.1 & 4.9 & - & - \\
\hline Czech & 101 & 47 & 10.0 & 0.83 & 0.78 & 7.6 & 9.5 & - & 1.4 \\
\hline Denmark & 82 & 63 & 10.8 & 0.90 & 0.92 & 6.0 & - & - & 1.2 \\
\hline Estonia & 133 & 41 & 9.3 & 0.87 & 0.86 & 7.0 & 8.3 & - & - \\
\hline Finland & 118 & 39 & 10.3 & 0.86 & 0.62 & 7.8 & - & 2.3 & - \\
\hline France & 123 & 52 & 11.9 & 0.71 & 0.77 & 8.7 & 10.7 & 2.8 & 0.9 \\
\hline Germany & 101 & 43 & 10.5 & 0.87 & 0.79 & 8.0 & 8.5 & 4.0 & 1.2 \\
\hline Greece & 75 & 46 & 6.2 & 0.74 & 0.56 & 5.9 & 4.1 & 3.1 & 0.7 \\
\hline Hungary & 96 & 44 & 7.8 & 0.81 & 0.51 & 7.1 & 6.1 & 2.0 & 0.7 \\
\hline Ireland & 109 & 50 & 10.0 & 0.82 & 0.67 & 8.0 & - & 2.7 & 1.1 \\
\hline Italy & 114 & 73 & 9.6 & 0.73 & 0.78 & 9.6 & 7.4 & 2.6 & - \\
\hline Latvia & 110 & 64 & 7.3 & 0.87 & 0.77 & 7.5 & 8.8 & - & - \\
\hline Lithuania & 113 & 49 & 7.6 & 0.66 & 0.24 & 7.7 & 10.3 & 2.0 & 0.6 \\
\hline Luxembourg & 131 & 39 & 7.8 & 0.95 & 0.76 & 6.4 & 8.9 & - & - \\
\hline Malta & 80 & 62 & 10.3 & 0.83 & 0.58 & 5.7 & 4.6 & 2.5 & - \\
\hline Netherlands & 141 & 41 & 10.8 & 0.74 & 0.82 & 8.4 & 12.2 & 5.1 & 1.3 \\
\hline Poland & 93 & 41 & 7.6 & 0.74 & 0.86 & 8.3 & 6.7 & 2.7 & 0.8 \\
\hline Portugal & 118 & 58 & 7.7 & 0.66 & 0.53 & 9.0 & 5.9 & 2.3 & - \\
\hline Romania & 88 & 65 & 7.4 & 0.52 & 0.29 & 10.2 & 6.2 & - & - \\
\hline Slovakia & 107 & 57 & 7.4 & 0.76 & 0.71 & 8.0 & 8.0 & - & - \\
\hline Slovenia & 104 & 46 & 8.0 & 0.24 & 0.15 & 7.1 & 6.3 & 0.5 & - \\
\hline Spain & 130 & 60 & 9.3 & 0.86 & 0.84 & 6.9 & 8.1 & 3.7 & - \\
\hline Sweden & 140 & 73 & 11.1 & 0.86 & 0.80 & 7.3 & - & 3.4 & - \\
\hline UK & 135 & 54 & 11.2 & 0.74 & 0.79 & 7.9 & - & 3.9 & 1.1 \\
\hline Average $^{\mathrm{a}}$ & 111 & 52 & 9.9 & 0.74 & 0.73 & 8.0 & 6.6 & 2.9 & 0.9 \\
\hline Median & 109 & 50 & 9.6 & 0.82 & 0.77 & 7.7 & 8.1 & 2.7 & 1.1 \\
\hline $\mathrm{SD}^{\mathrm{b}}$ & 20 & 10 & 1.6 & 0.14 & 0.22 & 1.1 & 2.1 & 1.1 & 0.2 \\
\hline
\end{tabular}




\subsubsection{Feed conversion and nitrogen use efficiency}

Table 3-4 shows the calculated average feed conversion ratio (FCR), $\mathrm{N}$ use efficiency (NUE), feed energy conversion to edible energy ratio (FER) and feed-to-animal protein conversion ratio (FPR) for the main animal categories in the EU-27. Beef cattle had on average the highest FCR, FPR and FER, and the lowest NUE. The FCR was relatively low for dairy cows, compared to other animal categories. Broilers had the highest NUE and the lowest FPR. The average FER of pigs was lower than that of other categories.

Table 3-4. Feed conversion ratio (FCR), nitrogen use efficiency (NUE), feed energy conversion to edible energy ratio (FER) and feed-to-animal protein conversion ratio (FPR), expressed in weighted averages $( \pm \mathrm{SD})$ for the EU-27 .

\begin{tabular}{lllll}
\hline Animal category (product) & $\begin{array}{l}\mathrm{FCR} \\
\left(\mathrm{kg} \mathrm{kg}^{-1}\right)\end{array}$ & $\begin{array}{l}\mathrm{NUE} \\
(\%)\end{array}$ & $\begin{array}{l}\text { FER } \\
\left(\mathrm{MJ} \mathrm{MJ}^{-1}\right)\end{array}$ & $\begin{array}{l}\text { FPR } \\
\left(\mathrm{kg} \mathrm{kg}^{-1} \text { protein }\right)\end{array}$ \\
\hline Dairy cows (cow milk) & $1.0 \pm 0.2$ & $23 \pm 4$ & $5.1 \pm 1.0$ & $30 \pm 6$ \\
Other cattle (live-weight gain) & $12.6 \pm 5.6$ & $9 \pm 3$ & $22.7 \pm 9.6$ & $77 \pm 35$ \\
Pigs (live-weight gain) & $2.9 \pm 0.5$ & $33 \pm 5$ & $3.1 \pm 0.5$ & $19 \pm 3$ \\
Laying hens (eggs) & $2.5 \pm 0.5$ & $26 \pm 7$ & $7.3 \pm 1.6$ & $22 \pm 5$ \\
Broilers (live-weight gain) & $2.4 \pm 0.5$ & $40 \pm 14$ & $4.3 \pm 0.7$ & $13 \pm 3$ \\
\hline
\end{tabular}

${ }^{\mathrm{a}} \mathrm{FCR}$ indicates the dry mass of feed use per mass of animal products (milk and eggs) or live-weight gain; NUE indicates the amount of nitrogen retained in animal products as percentage of total feed nitrogen intake; FER indicates the feed energy conversion into per unit human edible energy of animal product; FPR indicates the dry mass of feed use per $\mathrm{kg}$ of protein in animal products.

\subsubsection{Sensitivity analyses}

Increasing animal production by 5\% increased total feed use by $2.2 \%(\sim 11 \mathrm{Tg})$ in EU-27, and by $4.5 \%$ ( 23 $\mathrm{Tg}$ ) when simultaneously increasing animal number by $5 \%$ (Figure $3-6)$. A $5 \%$ increase of animal production and animal number resulted in a $4 \%$ increase in $\mathrm{N}$ excretion. Altering average live weight of animals by $5 \%$ resulted in a $\sim 2.4 \%$ change in feed DM use and in a $\sim 3.0 \%$ change in total $\mathrm{N}$ excretion. Changing energy contents of cereals and grass by $5 \%$ changed total feed use with about $7-8 \mathrm{Tg}$, or $1.3-1.5 \%$ of the baseline value. The effect of changes in feed protein content (grass, cereals and protein-rich feed) on total feed use was minute (Figure 3-6). However, changing the $\mathrm{N}$ content in grass by $10 \%$ changed total $\mathrm{N}$ excretion in EU-27 by $\sim 4 \%$ relative to the baseline value (Figure $3-6$ ). These effects (sensitivity extents) varied largely between countries (see standard deviations present in Figure 3-6) 


\section{Chapter 3}

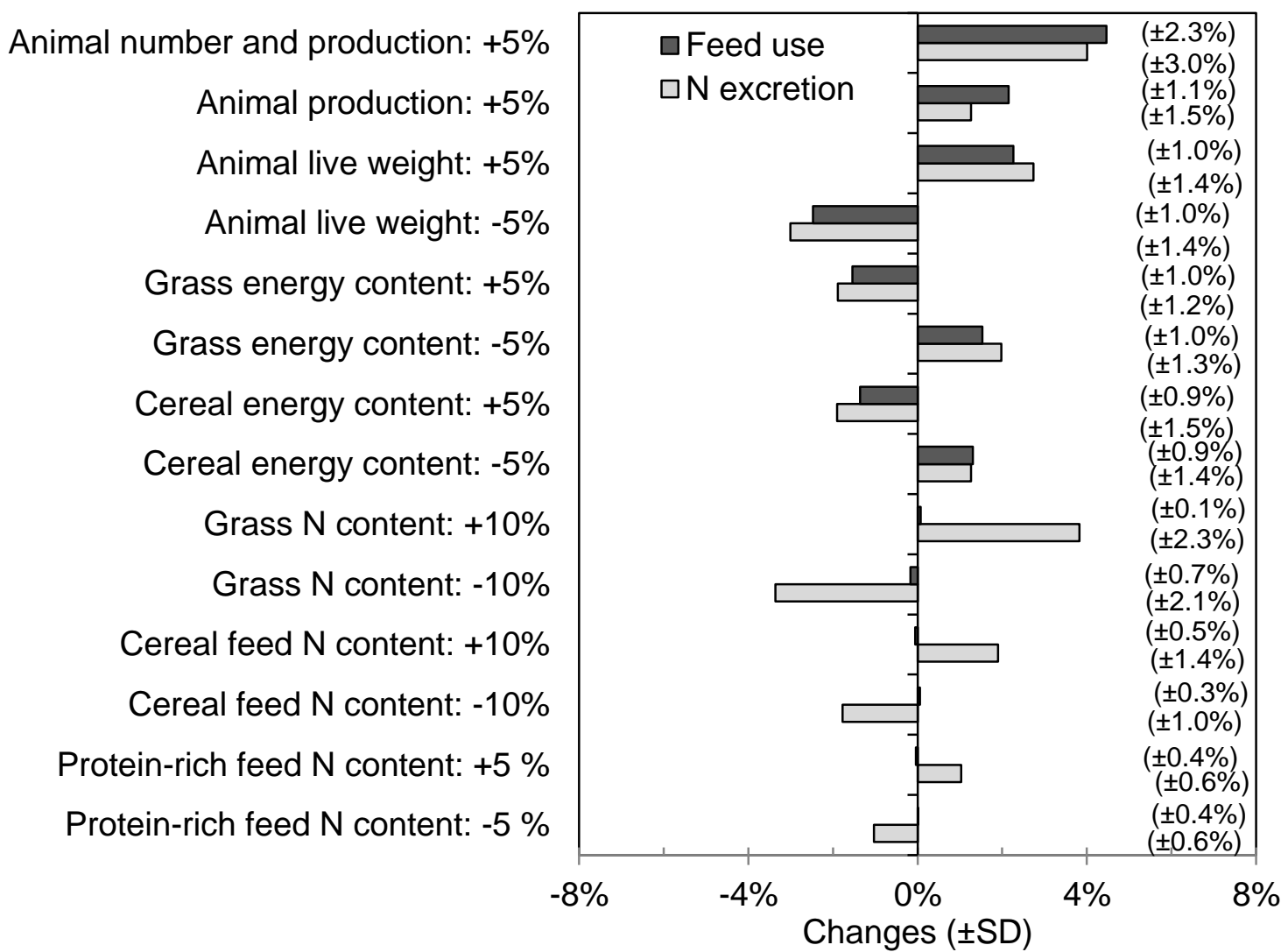

Figure 3-6. Effects of changing parameters on total feed dry mass use and nitrogen $(\mathrm{N})$ excretion of the animals in the EU-27. Changes from the baseline by the respective assumptions were calculated and expressed as a percentage of the baseline value. Standard deviations (SD) are present in the parentheses, indicating the variance between countries. For more details see Section 3.2.7.

\subsection{Discussion}

We developed a transparent methodology for the estimation of feed use and $\mathrm{N}$ excretion by livestock in all countries of the EU-27, based on the mass balance of feed supply and demand, statistical data and an optimization routine. The advantage of this methodology is that feed use and $\mathrm{N}$ excretions are estimated in a uniform manner for all Member States. Possible changes in feed supply and animal production statistics will be reflected in feed use and $\mathrm{N}$ excretion coefficients.

Currently, there are large differences within and between countries in the methodologies applied for estimating and reporting $\mathrm{N}$ excretion coefficients that serve national inventories of $\mathrm{NH}_{3}$ and greenhouse gas emissions (Velthof et al., 2015). Our methodology could be used as a benchmark for national estimates. The methodology designed here for quantifying $\mathrm{N}$ excretions in the EU can easily be applied for the estimation of other nutrient excretions (e.g., 
phosphorus, potassium), based on the calculated feed use and the nutrient contents of feed and animal products. Our methodology can be used also for global assessments. We used threeyears averages (2009-2011) to obtain a robust mean, but the methodology is equally applicable to annual data.

Linking feed use to $\mathrm{N}$ excretion coefficients facilitates the analysis of emission mitigation potentials of animal diet-related strategies. For example, decreasing the proportion of proteinrich feed in the ration of animals to an optimal level is an effective measure to reduce $\mathrm{N}$ emissions from the whole manure management chain (Hou et al., 2015). Linking feed use to specific animal categories allows also to allocate feed production related resource use (e.g., land, water, fertilizers) and greenhouse gas emissions to individual animal categories and animal food products (e.g., Tilman and Clark, 2014). Ranking various animal products according to the associated environmental (e.g., $\mathrm{N}$ footprints) and human health impacts may facilitate the implementation of revised dietary recommendations (Eshel et al., 2014; Galloway et al., 2014). Our method addresses various key livestock categories simultaneously, using a uniform methodology and common national statistics, and provides national averages, which allow direct comparison of feed use and $\mathrm{N}$ excretion coefficients among countries.

\subsubsection{Differences between the Member States}

Dairy cattle is the dominant animal category in the EU-27 in terms of feed use, $\mathrm{N}$ excretion (Figure 3-4), and emissions of $\mathrm{NH}_{3}$ and greenhouse gases (Lesschen et al., 2011). Countries with large dairy herds in 2009-2011 were Germany, France, Poland, UK, Italy, The Netherlands, together using nearly $70 \%$ of the total dairy feed use in EU-27 (Table S6). However, the rations of dairy cows differed between these countries (Figure 3-3). Dairy cows in UK and The Netherlands were fed grass-based diets, while dairy cows in Poland and Italy were fed relatively large portions of annual forages (Figure 3-3), which reflects the estimated availability of grass and annual forages in these countries (Figure 3-2). Statistics Netherlands reported that the average ration of dairy cows in The Netherlands during 2006-2008 included $54-64 \%$ grass and 12-27\% maize silage, depending on region (CBS, 2012), which is comparable with our results (60\% grass and $18 \%$ annual forages at national level). The feed use per dairy cow was related to milk yield and feed use efficiency (Figure 3-3). Some countries (e.g., Spain, Sweden) had relatively high milk yields (>7500 kg milk yr $\left.{ }^{-1}\right)$ and high feed intake (nearly $7500 \mathrm{~kg} \mathrm{DM} \mathrm{yr}^{-1}$ ) per animal, while other countries (e.g., Bulgaria, Greece,

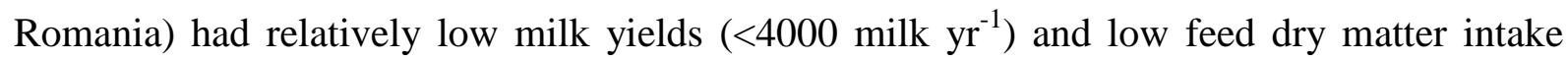




\section{Chapter 3}

(<5000 kg DM $\left.\mathrm{yr}^{-1}\right)$. Other countries (e.g., The Netherlands, UK) combined a relatively high milk yield (> $7400 \mathrm{~kg} \mathrm{milk} \mathrm{yr}^{-1}$ ) with a modest feed dry matter intake per head $(6500 \sim 7000 \mathrm{~kg}$ $\mathrm{DM} \mathrm{yr}^{-1}$ ), which can be explained by relatively high quality feed and good feed management. Results from the present study show that the aforementioned countries with high milk yields appear to have a relatively efficient feed use at animal level (i.e., FCR ranges between 0.8-1.0; and NUE ranges between 22-25\%, Tables S10-11), compared to countries with low milk yields (FCR ranges between 1.3-1.4; and NUE ranges between 17-20\%). Our NUE estimates for dairy cows are similar to estimates derived from studies at dairy farms in Spain (mean NUE of 22\%; Arriaga et al., 2010) and The Netherlands (NUE ranged from 23-26\%; Oenema et al., 2012).

Large pork producers include Germany, Spain, France, Poland, Denmark, The Netherlands and Italy; these seven countries accounted for $75 \%$ of the total pig feed use in the EU-27. Differences in the rations between countries were relatively small, with cereals as the largest feed source in all countries (Figure 3-3). This study estimated that over 34\% of protein-rich feed and nearly 53\% of feed cereals in EU-27 were used by pigs. Herrero et al. (2013) also reported that most of feed concentrates (cereals, pulses, etc.) are fed to pigs $(\sim 50 \%)$ and poultry $(\sim 20 \%)$ in regions where industrial systems dominate (e.g., Europe, North America). The quantity of feed use per head per year varied greatly between Member States (Figure 3-3), mainly due to differences in the live-weight gain per stock, which is related to the live weigh at slaughtering and pig husbandry characteristics. A relatively high feed intake ( $\sim 680 \mathrm{~kg}$ DM per stock) was estimated for Germany and Italy due to a high live-weight gain per stock (265 and $230 \mathrm{~kg}$, respectively) and a high live weight at slaughtering (123 and $157 \mathrm{~kg}$, respectively). Feed use (Figure 3-3) and live weight gain ( 140 kg) per stock were relatively low in the Netherlands, which is in part related to the export of piglets to other countries, including Germany and Italy.

Large differences were observed between countries for the total amount of $\mathrm{N}$ in manure and the amount of $\mathrm{N}$ excreted per ha of utilized agricultural area (UAA) (Table 3-2). A relatively high $\mathrm{N}$ excretion in $\mathrm{kg} \mathrm{N}^{-1}$ UAA was found for the Netherlands, Belgium, Ireland and Denmark (Table 3-2). These countries with high animal $\mathrm{N}$ excretion loads have also relatively high $\mathrm{N}$ losses $\left(\mathrm{NH}_{3}\right.$ and $\mathrm{N}_{2} \mathrm{O}$ emissions, $\mathrm{N}$ leaching, etc.) per ha of UAA (Oenema et al., 2007; Velthof et al., 2009). 


\subsubsection{Feed supply-use balance}

The total feed dry mass potentially available in the EU-27 in 2010 was estimated at $593 \mathrm{Tg}$, and the calculated total feed use by the main animal categories amounted to $506 \mathrm{Tg}$. Lesschen et al. (2011) estimated a similar amount of feed use (509 $\mathrm{Tg}$ ) for the EU-27 in 2005 . The difference $(87 \mathrm{Tg}$ ) between the amount of feed potentially available and the calculated feed requirement may be explained by various factors. Firstly, minor animal categories (horses, fur animals, rabbits, etc.) and animals at 'hobby farms' were not taken into account. Secondly, feed conservation losses and feed wastes were not considered. Feed conservation losses of grass and forage silages are usually in the range of 5-10\% and those for concentrate feeds in the range of 2 to 5\% (McGechan, 1989, 1990; McCormick et al., 2011). Feed wastes (i.e., the feed discarded by the animals) are also in the range of $2-5 \%$, depending on feed quality. Thirdly, there are competing uses for some forages, such as silage maize in anaerobic digesters (Pedroli \& Langeveld, 2011). This in part explains that forages from arable land (silage maize, leguminous crops, root crops, crop residues etc.) had a relatively large mismatch between supply and use in our calculations. Fourth, there are uncertainties in the feed statistics, particularly in grass and forage statistical data (Smit et al., 2008), and uncertainties in animal numbers. For example, there is transport of live animals across some borders (summarized in Table S8; FAOSTAT, 2014), which is related to the specialization of animal production systems in some regions. Some countries import animals for raising the animals to final weight, while other countries may import animals at slaughter weight to fully utilize the slaughterhouse capacity. We did not correct for net import, because of the uncertainties related to live weight of the imported animals. Thus, the import-export of live animals creates uncertainties in the estimated national feed use and $\mathrm{N}$ excretion coefficients.

\subsubsection{Comparison of $N$ excretion with other studies}

Nitrogen excretion coefficients are critically important parameters for agricultural $\mathrm{N}$ balances and national inventories of $\mathrm{NH}_{3}$ and $\mathrm{N}_{2} \mathrm{O}$ emissions and nitrate leaching from agriculture, which have to be reported for the evaluation and underpinning of EU and United Nations (UN) policies (Oenema et al., 2011; Velthof et al., 2015). The impacts of these agri-environmental policies and possible changes in these policies are evaluated by integrated assessment models such as GAINS (Asman et al., 2011) and CAPRI (Britz \& Witzke, 2012). Both models estimate $\mathrm{N}$ excretions and emissions of $\mathrm{NH}_{3}$ and $\mathrm{N}_{2} \mathrm{O}$ from animal manures per country, but use in part different approaches. Our estimates of the $\mathrm{N}$ excretion per animal category per 


\section{Chapter 3}

country were compared with those from Eurostat, national inventory reports (NIRs) to UNFCCC, GAINS and CAPRI (Figure 3-7). The total N excretion estimates for GAINS and CAPRI models were updated, using the animal number data from Eurostat for the years 20092011, but the animal excretion coefficients from GAINS and CAPRI. There is a good agreement between the estimates for total $\mathrm{N}$ excretion per country (Figure 3-7a) and the total $\mathrm{N}$ excretion by cattle (Figure 3-7b). Total $\mathrm{N}$ excretions by pigs (Figure 3-7c) and chicken (Figure 3-7d) are largely comparable, except for those from CAPRI. CAPRI reported relatively high $\mathrm{N}$ excretions for pigs and relatively low values for chicken. The reason for these differences is unclear, but it is likely due to the differences in the methods and data sources used to estimate $\mathrm{N}$ excretion coefficients. Differences between our estimates and those from Eurostat and NIRs were also relatively large for some countries, e.g., Romania and France (Figure 3-7). These differences are likely related to the use of IPCC default coefficients in the national reports (Velthof et al., 2015).
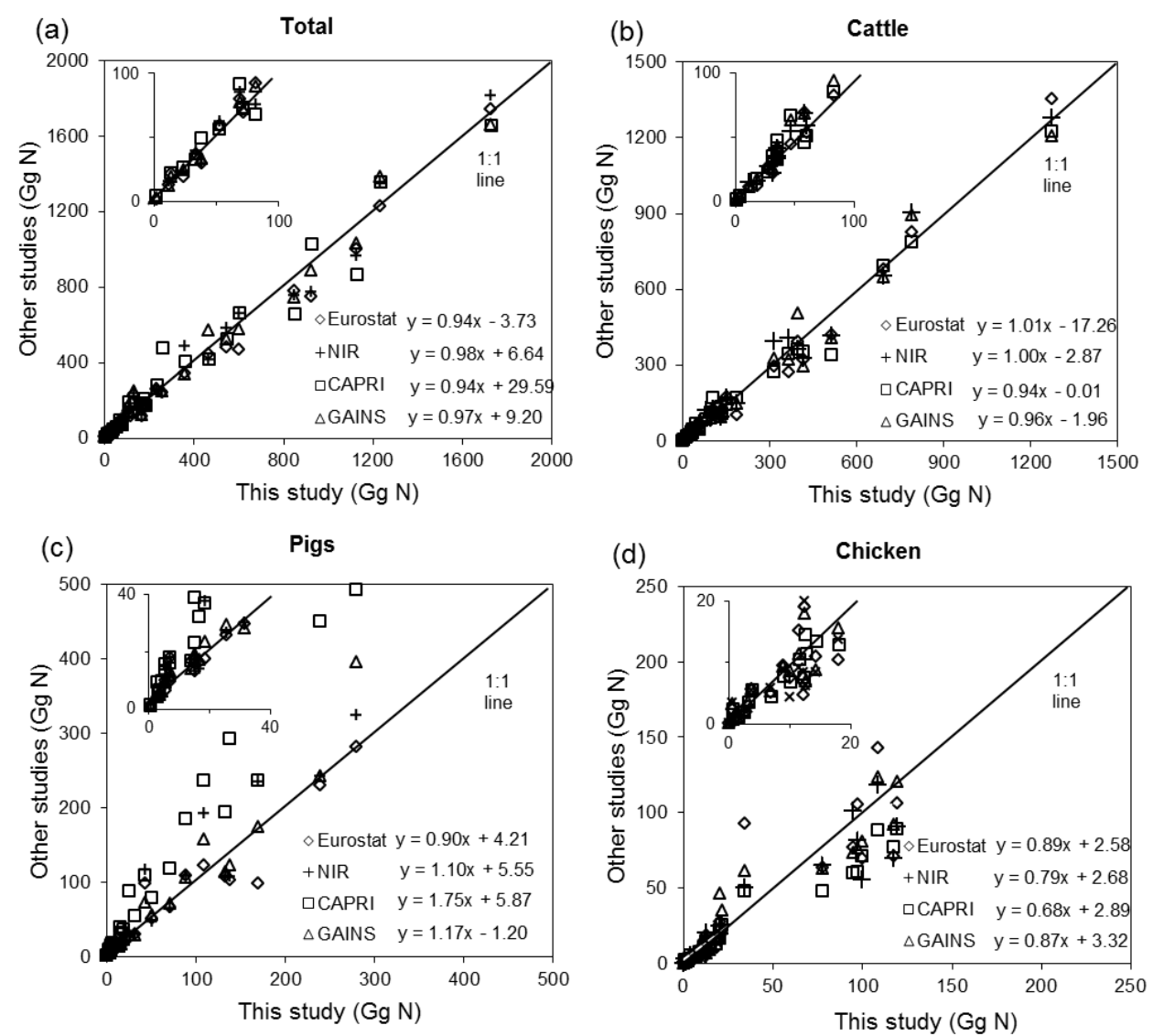

Figure 3-7. Comparisons of nitrogen $(\mathrm{N})$ excretion $\left(\mathrm{Gg}=10^{9} \mathrm{~g}\right)$ per country ( $\mathrm{a}$; the sum of all animal categories) or per animal category (b-d) with other studies: Eurostat, National inventory reports (NIR) to the UNFCCC, CAPRI model and GAINS model. Linear equations are shown corresponding to each pair of comparison. Magnified subfigures are included. 


\subsection{Conclusions}

Our study is the first assessment of feed use and $\mathrm{N}$ excretion per animal category and country in the EU-27, using a uniform methodology. Such a methodology is a necessary first step for environmental impact assessments of livestock production and manure management (i.e., the whole feed production-to-manure use chain) at animal category, at regional and national scales. Currently, various approaches and methods are being used for estimating the total $\mathrm{N}$ excretion per animal category at regional and national levels. These different approaches often lead to different estimates, and complicate comparisons between regions and countries. Our methodology could be used as a benchmark for these studies.

The total annual feed dry mass use by livestock in EU-27 during the years 2009-2011 was estimated at $\sim 506 \mathrm{Tg}$, and total $\mathrm{N}$ excretion at $\sim 9.7 \mathrm{Tg}$. There were large differences between countries in feed use per animal category, which led to differences in feed use efficiency and $\mathrm{N}$ excretion per animal category. Hence, feed use and management must be considered in environmental impact studies of livestock production and manure management systems.

We estimated a relatively large difference $(87 \mathrm{Tg})$ between total potential feed supply and total feed requirement in EU-27. We identified several possible reasons for this difference, which must be explored further. This difference may however, also have implications for agrienvironmental policies. Evidently, our methodology allows to assess the effects of possible changes in for example agricultural policy (CAP reform) and biofuel policy on feed use, feed use efficiency and $\mathrm{N}$ excretion per animal category. Accurate estimations of $\mathrm{N}$ excretions are also essential for assessing $\mathrm{N}$ emission mitigation measures and policies for animal production systems.

\section{Acknowledgements}

This research has received funding from the People Programme (Marie Curie Actions) of the European Union's Seventh Framework Programme FP7/2007-2013/under REA grant agreement no 289887. O. Oenema and G.L Velthof were financially supported by the Interreg IVB NWE programme (project Biorefine). J.P. Lesschen was financially supported by the EU FP7 project AnimalChange (Grant agreement 266018). Assistance from Wietse Dol (Wageningen University and Research Centre) in the linear programming is gratefully 


\section{Chapter 3}

acknowledged. The results and conclusions achieved reflect only the authors' view and the Union is not liable for any use that may be made of the information contained therein.

\section{Appendix A. Supplementary data}

Supplementary data associated with this article can be found, in the online version, at http://dx.doi.org/10.1016/j.agee.2015.11.025. 


\section{References}

Arriaga H, Salcedo G, Calsamiglia S, Merino P (2010) Effect of diet manipulation in dairy cow N balance and nitrogen oxides emissions from grasslands in northern Spain. Agriculture, Ecosystems \& Environment, 135, 132-139.

Asman WAH, Klimont Z, Brink C (2011) A simplified model of nitrogen flows from manure management. IIASA Interim Report IR-11-030. International Institute for Applied Systems Analysis (IIASA), Laxenburg, Austria.

Bai ZH, Ma L, Qin W, Chen Q, Oenema O, Zhang FS (2014) Changes in pig production in China and their effects on nitrogen and phosphorus use and losses. Environmental science \& technology, 48, 12742-12749.

Bellarby J, Tirado R, Leip A, Weiss F, Lesschen JP, Smith P (2013) Livestock greenhouse gas emissions and mitigation potential in Europe. Global change biology, 19, 3-18.

Bittman S, Dedina M, Howard C, Oenema O, Sutton M (2014) Options for Ammonia Mitigation: Guidance from the UNECE Task Force on Reactive Nitrogen. Centre for Ecology and Hydrology, Edinburgh, UK.

Bouwman AF, Van Der Hoek KW, Eickhout B, Soenario I (2005) Exploring changes in world ruminant production systems. Agricultural Systems, 84, 121-153.

Britz W, Witzke H-P (2012) CAPRI model documentation 2012 :Version 2012. Institute for Food and Resource Economics, University of Bonn, Bonn.

CBS (2012) Standardised calculation methods for animal manure and nutrients: Standard data 19902008. Statistics Netherlands, The Hague, 82 pp.

EEA (2014) European Union emission inventory report 1990-2012 under the UNECE Convention on Long-range Transboundary Air Pollution (LRTAP). 130 pp.

Eshel G, Shepon A, Makov T, Milo R (2014) Land, irrigation water, greenhouse gas, and reactive nitrogen burdens of meat, eggs, and dairy production in the United States. Proceedings of the National Academy of Sciences, 111, 11996-12001.

Eurostat, 2014 http://ec.europa.eu/eurostat/data/database (accessed 01 October 2014).

FAOSTAT, 2014. http://faostat.fao.org/ (accessed 01 October 2014).

Feedipedia, 2014. Feedipedia: An on-line encyclopedia of animal feeds. INRA (French National Institute for Agricultural Research), CIRAD (French Agricultural Research Center for International Development, AFZ (French Association for Animal Production) and FAO (Food and Agriculture Organization of the United Nations). http://www.feedipedia.org/ (accessed 01 October 2014).

Galassi G, Colombini S, Malagutti L, Crovetto GM, Rapetti L (2010) Effects of high fibre and low protein diets on performance, digestibility, nitrogen excretion and ammonia emission in the heavy pig. Animal Feed Science and Technology, 161, 140-148.

Galloway JN, Dentener FJ, Capone DG et al. (2004) Nitrogen Cycles: Past, Present, and Future. Biogeochemistry, 70, 153-226.

Galloway JN, Winiwarter W, Leip A, Leach AM, Bleeker A, Erisman JW (2014) Nitrogen footprints: past, present and future. Environmental Research Letters, 9, 115003.

Herrero M, Havlík P, Valin H et al. (2013) Biomass use, production, feed efficiencies, and greenhouse gas emissions from global livestock systems. Proceedings of the National Academy of Sciences of the United States of America, 110, 20888-20893.

Hou Y, Velthof GL, Oenema O (2015) Mitigation of ammonia, nitrous oxide and methane emissions from manure management chains: a meta-analysis and integrated assessment. Global Change Biology, 21, 1293-1312. 


\section{Chapter 3}

Intergovernmental Panel on Climate Change (IPCC). (2006) Chapter 10. Emissions from livestock and manure management. In: 2006 IPCC guidelines for national greenhouse gas inventories. Volume 4: Agriculture, forestry and other land use. 10.1-10.87 pp.

Kastner T, Rivas MJI, Koch W, Nonhebel S (2012) Global changes in diets and the consequences for land requirements for food. Proceedings of the National Academy of Sciences, 109, 6868-6872.

Krausmann F, Erb K-H, Gingrich S, Lauk C, Haberl H (2008) Global patterns of socioeconomic biomass flows in the year 2000: A comprehensive assessment of supply, consumption and constraints. Ecological Economics, 65, 471-487.

Lesschen JP, van den Berg M, Westhoek HJ, Witzke HP, Oenema O (2011) Greenhouse gas emission profiles of European livestock sectors. Animal Feed Science and Technology, 166-167, 16-28.

McCormick ME, Han KJ, Moreira VR, Blouin DC, Forbes S (2011) Forage conservation efficiency and lactation response to bahiagrass conserved as barn-stored hay, outdoor-stored hay, or baleage. Journal of dairy science, 94, 2500-2507.

McGechan MB (1989) A review of losses arising during conservation of grass forage: Part 1, field losses. Journal of Agricultural Engineering Research, 44, 1-21.

McGechan MB (1990) A review of losses arising during conservation of grass forage: Part 2, storage losses. Journal of Agricultural Engineering Research, 45, 1-30.

NRC (1994) Nutrient Requirements of Poultry: Ninth Revised Edition. National Academy Press, Washington, D.C., $176 \mathrm{pp}$.

NRC (1998) Nutrient Requirements of Swine: Tenth Revised Edition. National Academy Press, Washington, D.C., $210 \mathrm{pp}$.

NRC (2000) Nutrient Requirements of Beef Cattle:Seventh Revised Edition. National Academy Press, Washington, D.C., 248 pp.

NRC (2001) Requirements of Dairy Cattle: Seventh Revised Edition. National Academy Press, Washington, D.C., $381 \mathrm{pp}$.

O'Connell JM, Callan JJ, O'Doherty JV (2006) The effect of dietary crude protein level, cereal type and exogenous enzyme supplementation on nutrient digestibility, nitrogen excretion, faecal volatile fatty acid concentration and ammonia emissions from pigs. Animal Feed Science and Technology, 127, 73-88.

Oenema O, Wrage N, Velthof GL, Groenigen JW, Dolfing J, Kuikman PJ (2005) Trends in Global Nitrous Oxide Emissions from Animal Production Systems. Nutrient Cycling in Agroecosystems, $72,51-65$.

Oenema O, Oudendag D, Velthof GL (2007) Nutrient losses from manure management in the European Union. Livestock Science, 112, 261-272.

Oenema O, Witzke HP, Klimont Z, Lesschen JP, Velthof GL (2009) Integrated assessment of promising measures to decrease nitrogen losses from agriculture in EU-27. Agriculture, Ecosystems \& Environment, 133, 280-288.

Oenema O, Bleeker A, Braathen NA et al. (2011) Nitrogen in current European policies. In: The European nitrogen assess ment (eds Sutton MA, Howard CM, Erisman JW, Billen G, Bleeker A, Grennfelt P, Grinsven H van, Grizzetti B), pp. 62-81. Cambridge University Press, Cambridge, UK.

Oenema J, van Ittersum M, van Keulen H (2012) Improving nitrogen management on grassland on commercial pilot dairy farms in the Netherlands. Agriculture, Ecosystems and Environment, 162, $116-126$.

Oenema O, Ju X, de Klein C et al. (2014) Reducing nitrous oxide emissions from the global food system. Current Opinion in Environmental Sustainability, 9-10, 55-64.

Olesen JE, Schelde K, Weiske A., Weisbjerg MR, Asman WAH, Djurhuus J (2006) Modelling greenhouse gas emissions from European conventional and organic dairy farms. Agriculture, 
Ecosystems \& Environment, 112, 207-220.

Pedroli B, Langeveld H (2011) Impacts of Renewable Energy on European Farmers. Final Report for the European Commission Directorate-General Agriculture and Rural Development. Alterra Wageningen UR, The Netherlands.

Philippe FX, Canart B, Laitat M et al. (2009) Gaseous emissions from group-housed gestating sows kept on deep litter and offered an ad libitum high-fibre diet. Agriculture, Ecosystems \& Environment, 132, 66-73.

Philippe FX, Laitat M, Nicks B, Cabaraux JF (2012) Ammonia and greenhouse gas emissions during the fattening of pigs kept on two types of straw floor. Agriculture, Ecosystems \& Environment, $150,45-53$.

Smit HJ, Metzger MJ, Ewert F (2008) Spatial distribution of grassland productivity and land use in Europe. Agricultural Systems, 98, 208-219.

Steinfeld H, Mooney HA, Schneider F, Neville LE (2010) Livestock in a Changing Landscape: Drivers, Consequences and Responses. Washington, DC, 416 pp.

Thornton PK (2010) Livestock production: recent trends, future prospects. Philosophical transactions of the Royal Society of London. Series B, Biological sciences, 365, 2853-2867.

Thornton PK, Herrero M (2010) Potential for reduced methane and carbon dioxide emissions from livestock and pasture management in the tropics. Proceedings of the National Academy of Sciences of the United States of America, 107, 19667-19672.

Tilman D, Clark M (2014) Global diets link environmental sustainability and human health. Nature, $515,518-522$.

USDA. 2011. United States Department of Agriculture (USDA) National Nutrient Database for Standard Reference. http://ndb.nal.usda.gov/ (accessed 15 November 2015).

Velthof GL, Oudendag D, Witzke HP, Asman W a H, Klimont Z, Oenema O (2009) Integrated assessment of nitrogen losses from agriculture in EU-27 using MITERRA-EUROPE. Journal of environmental quality, 38, 402-417.

Velthof GL, van Bruggen C, Groenestein CM, de Haan BJ, Hoogeveen MW, Huijsmans JFM (2012) A model for inventory of ammonia emissions from agriculture in the Netherlands. Atmospheric Environment, 46, 248-255.

Velthof GL, Lesschen JP, Webb J et al. (2014) The impact of the Nitrates Directive on nitrogen emissions from agriculture in the EU-27 during 2000-2008. The Science of the total environment, 468-469, 1225-33.

Velthof GL, Hou Y, Oenema O (2015) Nitrogen excretion factors of livestock in the European Union: a review. Journal of the Science of Food and Agriculture, 95, 3004-3014.

Webb J (2001) Estimating the potential for ammonia emissions from livestock excreta and manures. Environmental Pollution, 111, 395-406.

Wirsenius S (2000) Human use of land and organic materials: modeling the turnover of biomass in the global food system. Chalmers University, Göteborg, Sweden., 279 pp.

Wirsenius S, Azar C, Berndes G (2010) How much land is needed for global food production under scenarios of dietary changes and livestock productivity increases in 2030? Agricultural Systems, 103, 621-638. 



\section{CHAPTER 4}

Mitigation of ammonia, nitrous oxide and methane emissions from manure management chains: a meta-analysis and integrated assessment 


\title{
Chapter 4
}

\begin{abstract}
:
Livestock manure contributes considerably to global emissions of ammonia $\left(\mathrm{NH}_{3}\right)$ and greenhouse gases $(\mathrm{GHG})$, especially methane $\left(\mathrm{CH}_{4}\right)$ and nitrous oxide $\left(\mathrm{N}_{2} \mathrm{O}\right)$. Various measures have been developed to mitigate these emissions, but most of these focus on one specific gas and/or emission source. Here, we present a meta-analysis and integrated assessment of the effects of mitigation measures on $\mathrm{NH}_{3}, \mathrm{CH}_{4}$ and (direct and indirect) $\mathrm{N}_{2} \mathrm{O}$ emissions from the whole manure management chain. We analysed the effects of mitigation technologies on $\mathrm{NH}_{3}, \mathrm{CH}_{4}$ and $\mathrm{N}_{2} \mathrm{O}$ emissions from individual sources statistically using results of 126 published studies. Whole-chain effects on $\mathrm{NH}_{3}$ and $\mathrm{GHG}$ emissions were assessed through scenario analysis. Significant $\mathrm{NH}_{3}$ reduction efficiencies were observed for i) housing via lowering the dietary crude protein (CP) content (24-65\%, compared to the reference situation), for ii) external slurry storages via acidification (83\%) and covers of straw $(78 \%)$ or artificial films (98\%), for iii) solid manure storages via compaction and covering (61\%, compared to composting), and for iv) manure application through band spreading (55\%, compared to surface application), incorporation (70\%) and injection (80\%). Acidification decreased $\mathrm{CH}_{4}$ emissions from stored slurry by $87 \%$. Significant increases in $\mathrm{N}_{2} \mathrm{O}$ emissions were found for straw-covered slurry storages (by two orders of magnitude) and manure injection (by 26-199\%). These side-effects of straw covers and slurry injection on $\mathrm{N}_{2} \mathrm{O}$ emission were relatively small when considering the total GHG emissions from the manure chain. Lowering the CP content of feed and acidifying slurry are strategies that consistently reduce $\mathrm{NH}_{3}$ and $\mathrm{GHG}$ emissions in the whole chain. Other strategies may reduce emissions of a specific gas or emissions source, by which there is a risk of unwanted trade-offs in the manure management chain. Proper farm-scale combinations of mitigation measures are important to minimize impacts of livestock production on global emissions of $\mathrm{NH}_{3}$ and GHG.
\end{abstract}




\subsection{Introduction}

Livestock farming systems are main sources of emissions of ammonia $\left(\mathrm{NH}_{3}\right)$, nitrous oxide $\left(\mathrm{N}_{2} \mathrm{O}\right)$ and methane $\left(\mathrm{CH}_{4}\right)$. Emissions of $\mathrm{NH}_{3}$ are largely responsible for the acidification and eutrophication of nitrogen-limited ecosystems (Sutton et al., 2008). Emissions of $\mathrm{N}_{2} \mathrm{O}$ and $\mathrm{CH}_{4}$ contribute considerably to the radiative forcing of the atmosphere, as the global warming potentials of $\mathrm{N}_{2} \mathrm{O}$ and $\mathrm{CH}_{4}$ are, respectively, 298 and 25 times higher than that of $\mathrm{CO}_{2}$ per $\mathrm{kg}$ (IPCC, 2007). Approximately $40 \%$ of the global anthropogenic $\mathrm{NH}_{3}$ and $\mathrm{N}_{2} \mathrm{O}$ emissions are associated with manures from livestock production (Galloway et al., 2004; Oenema et al., 2005). Enteric fermentation and animal manure together contribute some $80 \%$ to the global $\mathrm{CH}_{4}$ emissions from agriculture and about $35-40 \%$ to the global anthropogenic $\mathrm{CH}_{4}$ emissions (Steinfeld et al., 2006).

Emissions of $\mathrm{NH}_{3}, \mathrm{CH}_{4}$ and $\mathrm{N}_{2} \mathrm{O}$ may occur simultaneously from different sources of manure management systems. Animal excreta in housing and manure storage systems, from grazing animals voided on pastures and from land following manure application are main sources of $\mathrm{NH}_{3}$ and $\mathrm{N}_{2} \mathrm{O}$. Enteric fermentation in ruminants is the dominant source of $\mathrm{CH}_{4}$ emissions. Manure storages are also a significant source of $\mathrm{CH}_{4}$ (Sommer et al., 2004). Most agricultural soils are a sink for $\mathrm{CH}_{4}$ and a source of $\mathrm{N}_{2} \mathrm{O}$, depending on drainage, soil properties, fertilization practices and climatic conditions (Oenema et al., 2001).

Series of measures have been developed to address manure-related emissions, and some have been implemented successfully in practice. However, effects of these measures are typically considered for a specific gas or emission source only (e.g. Petersen et al., 2007), although it is well-known now that measures may have possible environmental side-effects (i.e. pollution swapping). For example, some $\mathrm{NH}_{3}$ mitigation measures may increase $\mathrm{N}_{2} \mathrm{O}$ emissions from slurry storages, or enhance $\mathrm{CH}_{4}$ emissions from solid manures storages (Berg et al., 2006; Szanto et al., 2007; Hansen et al., 2009; Velthof \& Mosquera, 2011). Several recent studies have addressed the possible side-effects of $\mathrm{NH}_{3}$ mitigation measures on emissions of $\mathrm{N}_{2} \mathrm{O}$ and $\mathrm{CH}_{4}$, but a systematic quantitative assessment of the effects of mitigation options in the manure chain is still lacking (Novak \& Fiorelli, 2010; Webb et al., 2010; Chadwick et al., 2011; Montes et al., 2013).

Manure processing creates alternative nutrient management opportunities by producing manure products (e.g. anaerobic digestate, separated liquid and solid fractions, compost) that differ from untreated manure, and it can also induce changes in $\mathrm{NH}_{3}$ and GHG emissions 


\section{Chapter 4}

(Sommer et al., 2009). Manure processing has become increasingly popular in many countries. For instance, the European Commission recently conducted a survey on manure processing activities in 27 member states of the European Union (EU-27). The results of this survey show that manure processing currently has reached an average level of $7.8 \%$ of the livestock manure production in EU-27, although regional variations were large (Foged et al., 2011). Anaerobic digestion and separation technologies were responsible for the processing of $3.5 \%$ and $3.1 \%$ of the total livestock manure production in the EU, respectively (Foged et al., 2011). The fraction of manure processed is expected to increase in the near future in order to achieve the targets of governmental policies related to further increasing the use efficiencies of manure nutrients, mitigating $\mathrm{NH}_{3}$ and GHG emissions and to renewable energy. Therefore, there is a need to improve our understanding about emissions of $\mathrm{NH}_{3}$ and GHG from the use of manure processing products.

The overall objective of the current study is to make a quantitative assessment of the effects of (sets of) mitigation options on the $\mathrm{NH}_{3}, \mathrm{~N}_{2} \mathrm{O}$ and $\mathrm{CH}_{4}$ emissions from the whole manure chain, namely livestock housing, manure storage and land application. Firstly, the impacts of a suite of $\mathrm{NH}_{3}$ mitigation measures on $\mathrm{NH}_{3}$ emissions at individual stages, and also the associated impacts on $\mathrm{N}_{2} \mathrm{O}$ and $\mathrm{CH}_{4}$ emissions were analysed by means of a meta-analysis of published data. Secondly, we evaluated the overall impacts of combinations of mitigation measures (including manure processing) on $\mathrm{NH}_{3}, \mathrm{CH}_{4}$, and (direct and indirect) $\mathrm{N}_{2} \mathrm{O}$ emissions from the whole manure management chain through scenario analysis.

\subsection{Materials and Methods}

\subsubsection{Manure management chain and emission mitigation measures}

An overview of studies examined here is shown in Table 4-1. These studies focused on different stages of the manure management chain (subjected to different management practices), namely housing (different dietary crude protein content in the animal feed, different floor constructions), storage of liquid manure (different covers, and acidification) and solid manure (compaction, covering, stockpiling, composting), and manure application to land (different application techniques, different processed manure products). Within each of these stages, emissions of $\mathrm{NH}_{3}, \mathrm{~N}_{2} \mathrm{O}$ and $\mathrm{CH}_{4}$ from manure are compared between given management practices (see Table 4-1). Pig and cattle manures were mainly considered in this meta-analysis. Measures for cattle manure during grazing and feeding strategies affecting $\mathrm{CH}_{4}$ emissions from enteric fermentation were excluded in the present study. 


\subsubsection{Literature search and study selection}

Studies related to manure management and emissions of $\mathrm{NH}_{3}, \mathrm{~N}_{2} \mathrm{O}$ and $\mathrm{CH}_{4}$ were searched using the bibliographic database Scopus, until the beginning of 2014. Specific search terms were combined, depending on animal category (animal, livestock, pig, swine, cattle or cow), manure type (slurry, waste, manure, compost, farmyard manure, digestate, liquid or solid), management measures (feeding: feed, diet, dietary manipulation or dietary crude protein; animal housing: housing, barn, slatted floor, deep litter, solid floor or straw floor; manure processing: acidification, acidified, separation, separated, digestion or biogas; slurry storage: storage, crust or cover; solid manure storage: compaction, cover, stockpiling, static piling, turning or compost; field application: band spreading, trailing hose, trailing shoe, injection, injected, incorporation or incorporated), and emissions (ammonia, methane, nitrous oxide or greenhouse gas emissions). For example, literature related to $\mathrm{NH}_{3}$ emissions from acidified pig slurry was searched with the following combination of terms "pig OR swine AND slurry OR manure AND acidification OR acidified AND ammonia" in article titles, abstracts and keywords in Scopus.

Only data from studies with reference treatments (i.e. without mitigation/processing measures) were included in our database, so as to allow side-by-side comparisons. To maximize the number of studies, both laboratory and field experiments were taken into account. The selected studies in our database and grouped side-by-side comparisons are listed in Table 4-1. The reported experiments and measurements were predominately conducted in EU, United States of America and Canada. Mean values of replicates for each treatment were included in the database. Manure characteristics (e.g. manure type, dry matter content, total $\mathrm{N}$ content, ammoniacal $\mathrm{N}$ content and $\mathrm{pH}$ ), land use parameters (e.g. soil texture, vegetation), environmental conditions (e.g. temperature, seasons and geographic locations) were also included, and used to, if possible, quantify their relationships with emissions and the effectiveness of the measures. 


\section{Chapter 4}

Table 4-1 Matrix showing which studies provided data for each stage of manure management on which effect sizes were estimated

\begin{tabular}{|c|c|c|c|c|}
\hline $\begin{array}{l}\text { Management } \\
\text { stages }\end{array}$ & $\begin{array}{l}\text { Emission sources } \\
\text { targeted }\end{array}$ & Pollutants & Grouped comparisons & References \\
\hline Feeding & Housing & $\mathrm{NH}_{3}$ & $\begin{array}{l}<2 \% \text { reduction in dietary } \mathrm{CP} \\
2-4 \% \text { reduction in dietary } \mathrm{CP} \\
>4 \% \text { reduction in dietary } \mathrm{CP}\end{array}$ & $\begin{array}{l}\text { Canh } \text { et al., 1998a; James et al., 1999; Külling et al., 2001; Frank \& Swensson, } \\
\text { 2002; Frank et al., 2002; Portejoie et al., 2004; Hayes et al., 2004; Leek et al., } \\
\text { 2005, 2007; Velthof et al., 2005; O'Connell et al., 2006; Panetta } \text { et al., 2006; } \\
\text { Lynch et al., 2007, 2008; Hansen } \text { et al., 2007; Le } \text { et al., 2008, 2009; van der Stelt } \\
\text { et al., 2008; Li et al., 2009; O'Shea et al., 2009; Agle } \text { et al., 2010; Arriaga } \text { et al., } \\
\text { 2010; Galassi } \text { et al., 2010; Hernández et al., 2011; Lee et al., 2012; Koenig } \text { et al., } \\
\text { 2013; Madrid } \text { et al., 2013; Montalvo et al., } 2013\end{array}$ \\
\hline Housing & Housing & $\mathrm{N}_{2} \mathrm{O}, \mathrm{CH}_{4}$ & $\begin{array}{l}\text { slatted floor/deep litter vs solid floor } \\
\text { slatted floor vs deep litter } \\
\text { litter removal frequently vs infrequently } \\
\text { extra straw addition vs no extra addition } \\
\text { slatted floor vs deep litter } \\
\text { litter removal frequently vs infrequently }\end{array}$ & $\begin{array}{l}\text { Groenestein \& Van Faassen, 1996; Kavolelis, 2006; Gilhespy et al., 2009; Amon } \\
\text { et al., 2007; Philippe et al., 2007a, 2007b, 2011, 2013; Ivanova-Peneva et al., } \\
\text { 2008; Cabaraux et al., 2009; Dourmad et al., 2009 } \\
\text { Groenestein \& Van Faassen, 1996; Amon et al., 2007; Philippe et al., 2007a, } \\
\text { 2007b, 2011; Cabaraux et al., 2009; Dourmad et al., 2009 }\end{array}$ \\
\hline \multirow[t]{2}{*}{ Acidification } & \multirow[t]{2}{*}{ External storage } & $\mathrm{NH}_{3}$ & acidified vs not acidified & $\begin{array}{l}\text { Kai et al., 2008; Petersen } \text { et al., 2012, 2014; Dai \& Blanes-Vidal, 2013; Wang et } \\
\text { al., } 2014\end{array}$ \\
\hline & & $\mathrm{CH}_{4}$ & acidified vs not acidified & Petersen et al., 2012, 2014; Wang et al., 2014 \\
\hline Slurry storage & External storage & $\mathrm{N}_{2} \mathrm{O}, \mathrm{CH}_{4}$ & $\begin{array}{l}\text { crusting vs no-crust } \\
\text { straw cover vs no-cover } \\
\text { wooden lid vs no-cover } \\
\text { wooden lid vs crusting } \\
\text { granules cover vs no-cover } \\
\text { artificial film cover vs no-cover } \\
\text { peat/kitchen oil cover vs no-cover } \\
\text { straw cover vs no-cover } \\
\text { wooden lid vs no-cover } \\
\text { wooden lid vs crusting } \\
\text { granules cover vs no-cover } \\
\text { granules cover + acids vs no-cover/acids } \\
\text { artificial film cover vs no-cover }\end{array}$ & $\begin{array}{l}\text { Sommer, 1997; Hörnig et al., 1999; Portejoie et al., 2003; Misselbrook et al., } \\
\text { 2005b; Balsari et al., 2006; Berg et al., 2006; Clemens et al., 2006; Amon et al., } \\
\text { 2007; Smith et al., 2007; VanderZaag et al., 2009; VanderZaag \& Gordon, 2010; } \\
\text { Petersen et al., } 2013\end{array}$ \\
\hline
\end{tabular}


Table 4-1 (continued)

\begin{tabular}{|c|c|c|c|c|}
\hline \multirow[t]{2}{*}{$\begin{array}{l}\text { Solid manure } \\
\text { storage }\end{array}$} & External storage & $\mathrm{NH}_{3}$ & $\begin{array}{l}\text { stockpiling vs turning (composting) } \\
\text { compaction/covering vs turning }\end{array}$ & $\begin{array}{l}\text { Sommer \& Dahl, 1999; El Kader et al., 2007; Sagoo et al., 2007; Szanto et al., } \\
\text { 2007; Jiang et al., } 2013\end{array}$ \\
\hline & & $\mathrm{N}_{2} \mathrm{O}, \mathrm{CH}_{4}$ & $\begin{array}{l}\text { stockpiling vs turning (composting) } \\
\text { compaction/covering vs turning }\end{array}$ & $\begin{array}{l}\text { Sommer \& Dahl, 1999; Hao et al., 2001; El Kader et al., 2007; Szanto et al., } \\
\text { 2007; Ahn et al., 2011; Jiang et al., } 2013\end{array}$ \\
\hline \multirow[t]{4}{*}{ Field application } & \multirow[t]{4}{*}{$\begin{array}{l}\text { Arable land and } \\
\text { grassland }\end{array}$} & $\mathrm{NH}_{3}$ & $\begin{array}{l}\text { band spreading vs surface spreading } \\
\text { incorporation vs surface spreading } \\
\text { injection vs surface spreading }\end{array}$ & $\begin{array}{l}\text { Malgeryd, 1998; Smith et al., 2000; Huijsmans et al., 2001; Wulf et al., 2002a; } \\
\text { Misselbrook et al., 2002; Rodhe \& Karlsson, 2002; Huijsmans, 2003; Mattila \& } \\
\text { Joki-Tokola, 2003; Webb et al., 2004, 2014; McGinn \& Sommer, 2007; Sagoo et } \\
\text { al., 2007; Bhandral et al., } 2009\end{array}$ \\
\hline & & $\mathrm{N}_{2} \mathrm{O}$ & $\begin{array}{l}\text { injection/incorporation vs surface spreading } \\
\text { injection/incorporation vs band spreading }\end{array}$ & $\begin{array}{l}\text { Sommer et al., 1996; Flessa \& Beese, 2000; Wulf et al., 2002b; Velthof et al., } \\
\text { 2003; Webb et al., 2014, 2004; Vallejo et al., 2005; Weslien } \text { et al., 2006; Rodhe et } \\
\text { al., 2006; Bhandral et al., 2009; Sistani } \text { et al., 2010; Thomsen } \text { et al., 2010; Velthof } \\
\text { \& Mosquera, } 2011\end{array}$ \\
\hline & & $\mathrm{NH}_{3}$ & $\begin{array}{l}\text { anaerobic digestate vs raw slurry } \\
\text { separated liquid fractions vs raw slurry }\end{array}$ & $\begin{array}{l}\text { Wulf et al., 2002a; Mattila et al., 2003; Amon et al., 2006; Chantigny et al., 2007, } \\
\text { 2009; Balsari et al., 2008; Bhandral et al., 2009; Möller \& Stinner, 2009; }\end{array}$ \\
\hline & & $\mathrm{N}_{2} \mathrm{O}$ & $\begin{array}{l}\text { anaerobic digestate vs raw slurry } \\
\text { separated liquid fractions vs raw slurry } \\
\text { separated solid fractions vs raw slurry }\end{array}$ & $\begin{array}{l}\text { Petersen, 1999; Vallejo et al., 2006; Clemens et al., 2006; Chantigny et al., 2007; } \\
\text { Fangueiro et al., 2007, 2008b, 2010; Bertora et al., 2008; Bhandral et al., 2009; } \\
\text { Möller \& Stinner, 2009; Pereira et al., 2010b; Thomsen et al., 2010; Chiyoka et } \\
\text { al., 2011; Collins } \text { et al., 2011; Dinuccio et al., 2011; Schouten } \text { et al., } 2012\end{array}$ \\
\hline
\end{tabular}




\section{Chapter 4}

\subsubsection{Derivation of the effect size and statistical analysis}

Standardization of the literature results was undertaken through calculation of the effect size (i.e. a measure of comparing two variables). This allows quantitative statistical information to be pooled, and robust statistical comparisons to be made between effects from a range of studies that reported results based on different experimental variables. For each side-by-side comparison (i.e. observation), the natural logarithm of the response ratio was calculated as the effect size $(\ln R)$ :

$\ln R=\ln \left(X_{A} / X_{B}\right)$

Where $\mathrm{X}_{\mathrm{A}}$ and $\mathrm{X}_{\mathrm{B}}$ represent the mean emissions in treatment $\mathrm{A}$ (mitigation measure or alternative practice) and treatment $\mathrm{B}$ (reference practice), respectively, for $\mathrm{NH}_{3}, \mathrm{~N}_{2} \mathrm{O}$ and $\mathrm{CH}_{4}$. Log-transformation of the response ratio was carried out to stabilize the variance. For calculation of grouped effect sizes, a mixed-effects model was used and performed in the nlme package of $\mathrm{R}$ statistical software Version 3.1 (Pinheiro et al., 2014). Mixed-effect models are preferable to fixed-effect models for statistical testing in ecological data synthesis because their assumption of variance heterogeneity is more likely to be satisfied (Gurevitch $e t$ al., 2001). Experimental sites were considered as a random effect factor, to allow accounting for variances among studies. The $\ln R$ of individual pairwise comparison was the dependent variable. The mean effect size and the 95\% confidence intervals (CIs) of each categorical group were estimated. The significance of the effects on emissions was statistically assessed at 0.05 level. In the graphs (forest plots), the "effect-size" (the mean value and 95\% CIs) of each grouping was transformed back (i.e. exponentially transformed) and converted to a percentage change in gas emissions relative to the reference treatment.

\subsubsection{Integrated assessment of management options}

Introducing a new technology or management measure to mitigate emissions from a particular source may affect the emissions downstream in the manure management chain. To examine such possible effects, a scenario analysis was conducted.

Impacts of changes in technologies and management measures were compared with the reference scenario. We defined scenarios for three contrasting pig farming systems, namely a slurry-based system, a solid manure-based system, and a slurry-based system with slurry separation. The reference scenarios (systems) and the $\mathrm{NH}_{3}$ emissions mitigation scenarios were derived from the UNECE Ammonia Guidance Document (Bittman et al., 2014). For the 
slurry-based system with slurry separation, we selected two contrasting separation techniques; a screw press (low separation efficiency) and a decanter centrifuge (high separation efficiency) (Hjorth et al., 2010). The reference and alternative scenarios are described in Table 4-2.

Emissions of $\mathrm{NH}_{3}, \mathrm{~N}_{2} \mathrm{O}$ and $\mathrm{CH}_{4}$ were calculated from the model pig manure management chains, divided into emissions from enteric fermentation $\left(\mathrm{CH}_{4}\right)$, houses, storage of manure and field application of manure.

Emissions of $\mathrm{NH}_{3}$ were calculated using the Tier 2 methodology of the EMEP/EEA air pollutant emission inventory guidebook (EMEP/EEA, 2013), based on the flow of TAN (total ammoniacal $\mathrm{N}$ ) and emission factors. This methodology enables estimation of the effects of measures on $\mathrm{NH}_{3}$ emissions at subsequent stages of the manure management chain. Emissions of $\mathrm{N}_{2} \mathrm{O}$ were calculated using the IPCC guidelines. Indirect $\mathrm{N}_{2} \mathrm{O}$ emissions resulting from $\mathrm{NH}_{3}$ emissions were included in the assessment (IPCC, 2006). A default emission factor of

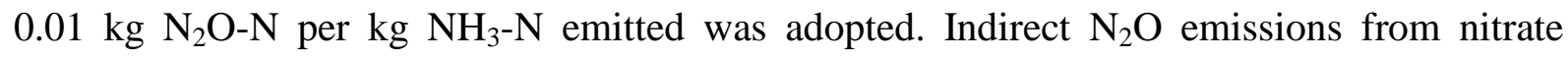
leaching were not considered. Methane emissions from enteric fermentation and from storage of slurry and solid manure were based on IPCC guidelines (IPCC, 2006). The overall GHG emissions were calculated and presented as $\mathrm{kg} \mathrm{CO}$-eq, using the default values of $298 \mathrm{~kg}$ $\mathrm{CO}_{2}$-eq for $\mathrm{N}_{2} \mathrm{O}$ emissions and $25 \mathrm{~kg} \mathrm{CO}_{2}$-eq for $\mathrm{CH}_{4}$ emissions (IPCC, 2007). Effects of new technologies and mitigation measures were estimated from the differences with the reference scenario. Average emission factors for the new technologies and mitigation measures were derived from the effect-size analysis of published data, as described before. Parameters used to calculate emissions from the reference systems and scenarios with mitigation measures and alternative practices can be found in the supplementary file (Table S1 and S2). 


\section{Chapter 4}

Table 4-2. Description of the reference scenario and the emission mitigation measures and technologies used for the scenario analysis

\begin{tabular}{|c|c|c|c|c|c|c|}
\hline \multirow[t]{2}{*}{ Scenario ID } & \multicolumn{2}{|l|}{ Housing } & \multirow{2}{*}{ Separation $^{\text {a }}$} & \multicolumn{2}{|l|}{ Storage } & \multirow[b]{2}{*}{ Field application } \\
\hline & Dietary $\mathrm{CP}$ content & Floor types & & $\begin{array}{l}\text { Slurry/liquid } \\
\text { fractions }\end{array}$ & $\begin{array}{l}\text { Solid manure/solid } \\
\text { fractions }\end{array}$ & \\
\hline \multicolumn{7}{|c|}{ Slurry-based system } \\
\hline Reference & Conventional & Slatted floor & & No-crust cover & & Surface spreading \\
\hline Diet $^{b}$ & $2 \%$ reduction & Slatted floor & & Crusting & & Surface spreading \\
\hline Acidification & Conventional & Slatted floor & & No-crust cover & & Surface spreading \\
\hline Straw cover & Conventional & Slatted floor & & Straw cover & & Surface spreading \\
\hline Artificial film & Conventional & Slatted floor & & Artificial film & & Surface spreading \\
\hline Band spreading & Conventional & Slatted floor & & No-crust cover & & Band spreading \\
\hline Injection & Conventional & Slatted floor & & No-crust cover & & Injection \\
\hline Acidification + injection & Conventional & Slatted floor & & Acidification & & Injection \\
\hline Straw + injection & Conventional & Slatted floor & & Straw cover & & Injection \\
\hline Artificial film + injection & Conventional & Slatted floor & & Artificial film & & Injection \\
\hline Diet + acidification + injection & $2 \%$ reduction & Slatted floor & & Acidification & & Injection \\
\hline Diet + straw cover + injection & $2 \%$ reduction & Slatted floor & & Straw cover & & Injection \\
\hline Diet + artificial film + injection & $2 \%$ reduction & Slatted floor & & Artificial film & & Injection \\
\hline \multicolumn{7}{|c|}{ Solid manure-based system } \\
\hline Reference & Conventional & Deep litter & & & Composting & Surface spreading \\
\hline Diet & $2 \%$ reduction & Deep litter & & & Composting & Surface spreading \\
\hline Stockpiling & Conventional & Deep litter & & & Stockpiling & Surface spreading \\
\hline Compaction & Conventional & Deep litter & & & Compaction & Surface spreading \\
\hline Incorporation & Conventional & Deep litter & & & Composting & Incorporation \\
\hline Stockpiling + incorporation & Conventional & Deep litter & & & Stockpiling & Incorporation \\
\hline Compaction + incorporation & Conventional & Deep litter & & & Compaction & Incorporation \\
\hline Diet + stockpiling + incorporation & $2 \%$ reduction & Deep litter & & & Stockpiling & Incorporation \\
\hline Diet + compaction + incorporation & $2 \%$ reduction & Deep litter & & & Compaction & Incorporation \\
\hline
\end{tabular}




\section{Table 4-2 (continued)}

\begin{tabular}{|c|c|c|c|c|c|c|}
\hline \multicolumn{7}{|c|}{ Slurry separation-inclusive system } \\
\hline Reference (slurry-based system) & Conventional & Slatted floor & & No-crust cover & & Surface spreading \\
\hline SEP I (Screw press) & Conventional & Slatted floor & Screw press & No-crust cover & Composting & Surface spreading \\
\hline SEP II (Centrifuge) & Conventional & Slatted floor & Centrifuge & No-crust cover & Composting & Surface spreading \\
\hline SEP I +diet & $2 \%$ reduction & Slatted floor & Screw press & No-crust cover & Composting & Surface spreading \\
\hline SEP II + diet & $2 \%$ reduction & Slatted floor & Centrifuge & No-crust cover & Composting & Surface spreading \\
\hline SEP I + deep placement & Conventional & Slatted floor & Screw press & No-crust cover & Composting & Deep placement ${ }^{\mathrm{c}}$ \\
\hline SEP II + deep placement & Conventional & Slatted floor & Centrifuge & No-crust cover & Composting & Deep placement \\
\hline SEP I + artificial film & Conventional & Slatted floor & Screw press & Artificial film & Composting & Surface spreading \\
\hline SEP II + artificial film & Conventional & Slatted floor & Centrifuge & Artificial film & Composting & Surface spreading \\
\hline SEP I + artificial film + stockpiling & Conventional & Slatted floor & Screw press & Artificial film & Stockpiling & Surface spreading \\
\hline SEP II + artificial film + stockpiling & Conventional & Slatted floor & Centrifuge & Artificial film & Stockpiling & Surface spreading \\
\hline
\end{tabular}

${ }^{a}$ separation efficiencies of N and DM (i.e. C), expressed as \% in solid fraction relative to raw slurry, were $10 \%$ and $25 \%$ for screw press, and $30 \%$ and $60 \%$ for centrifuge (after Hjorth et al., 2010).

${ }^{\mathrm{b}}$ natural surface crust is assumed to be generated when dietary $\mathrm{CP}$ level was reduced, because of increased proportion of DM-rich faeces in slurry with lowering dietary CP. The effect of reducing dietary $\mathrm{CP}$ on animal $\mathrm{N}$ excreta and emissions from manure are considered, but its effect on $\mathrm{CH}_{4}$ emissions from animal body is not considered in the scenario analysis.

${ }^{\mathrm{c}}$ separated liquid fractions were injected into soil and solid fractions were immediately incorporated into soil after land spreading. 


\subsection{Results}

\subsubsection{Emissions from housing - effects of dietary CP manipulation and housing constructions}

A total of 86 observations (37 from field-based experiments) were collected to analyse the effects of changes in crude protein (CP) content of the animal feed on $\mathrm{NH}_{3}$ emissions from animal excretion in stables (i.e. from housing and indoor manure storage). $\mathrm{The} \mathrm{NH}_{3}$ emission decreased by 24 to $65 \%$ with a lowering of the $\mathrm{CP}$ content. The largest decrease was derived at a $\mathrm{CP}$ reduction of $>4 \%$ (Figure 4-1). There was a significant linear relationship between $\mathrm{CP}$ content in the diet vs manure $\mathrm{pH}$, manure $\mathrm{N}$ content, amount of urine- $\mathrm{N}$ excreted and amount of total $\mathrm{N}$ excreted (Figure 4-2). The slopes of the two linear models (Figures 4-2a and b) show that one percent decrease in dietary $\mathrm{CP}$ content decreased the $\mathrm{pH}$ of the manure by on average $1.1 \%$ and the TN content of manure by $3.5 \%$.

Data derived from 11 farm-scale studies were used to test the effects of animal houses with distinct floor constructions on emissions. Animal houses with alternative floors tended to have lower $\mathrm{NH}_{3}$ emissions compared to the reference floor construction (Figure 4-1). The difference between slatted-floor/deep litter stables compared with solid-floor stables was statistically significant $(P<0.01)$. Buildings with slurries underneath slatted floor tended to have higher $\mathrm{CH}_{4}$ emissions, but significantly lower $\mathrm{N}_{2} \mathrm{O}$ emissions than buildings with deeplitter (Figure 4-3)

\subsubsection{Emissions from slurry storages - effects of acidification and covers}

Side-by-side comparisons were extracted from five studies in which the acidification-induced effects on emissions of $\mathrm{NH}_{3}$ and/or $\mathrm{CH}_{4}$ from stored slurries were estimated. One study was carried out at pilot scale and the other four in the laboratory; four studies used sulphuric acid $\left(\mathrm{H}_{2} \mathrm{SO}_{4}\right)$ and one study hydrochloric acid $(\mathrm{HCl})$. Statistically significant decreases in $\mathrm{NH}_{3}$ emissions from acidified slurries $(\mathrm{pH}=4.5-6.5)$ were observed; the mean emission reduction was $83 \%$ and the $95 \%$ CIs ranged from $60 \%$ to $90 \%$ (Figure 4-1). Slurry acidification also led to a statistically significant reduction (on average, 87\%) of $\mathrm{CH}_{4}$ emissions during slurry storage (Figure 4-3).

A total of 12 studies compared the effects of covers on the emission of $\mathrm{NH}_{3}$ from slurry storage, 10 of which were run at pilot or farm scales. Slurry storages covered by chopped straw, granules, artificial film, peat or oil had significant $(P<0.01)$ less $\mathrm{NH}_{3}$ emissions 
compared to storages without such covers (Figure 4-1). In addition, the presence of a natural surface crust tended to lower emissions by $65 \%$ (14-89\%) compared to storages without crust. Yet, the difference was statistically insignificant at the 0.05 level.

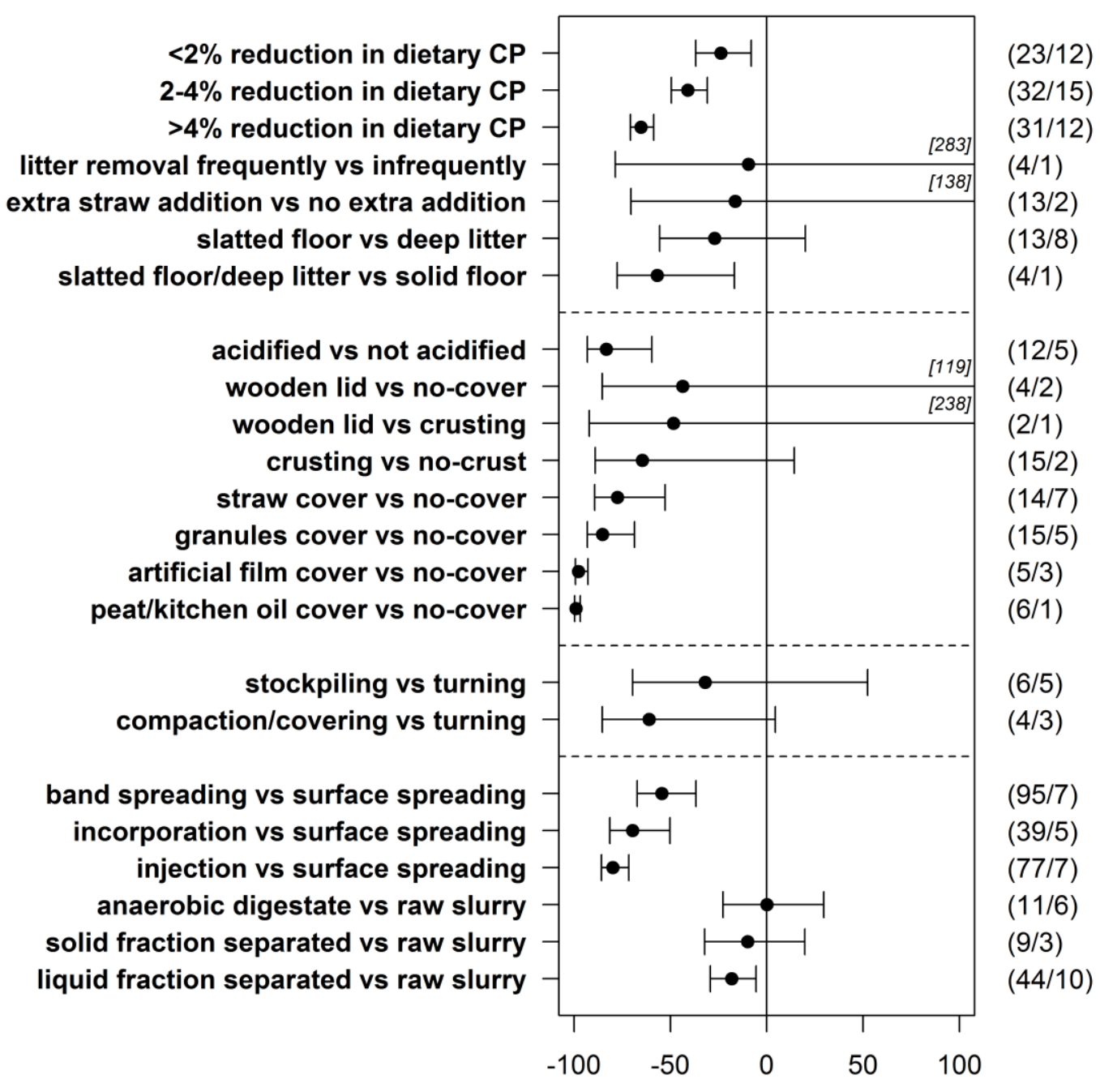

Changes in ammonia emissions (\%)

Figure 4-1. The mean change in $\mathrm{NH}_{3}$ emissions as a percentage of the reference treatment, for a number of grouped side-by-side comparisons between treatments with vs without mitigation measures. Points show means of treatments, bars show 95\% confidence intervals. The maximum values that exceed the scale of $\mathrm{x}$-axis are shown in brackets. Numbers in the parentheses indicate the number of observations on which the statistical analysis was based, and the number of different studies from which the observations originated.. 


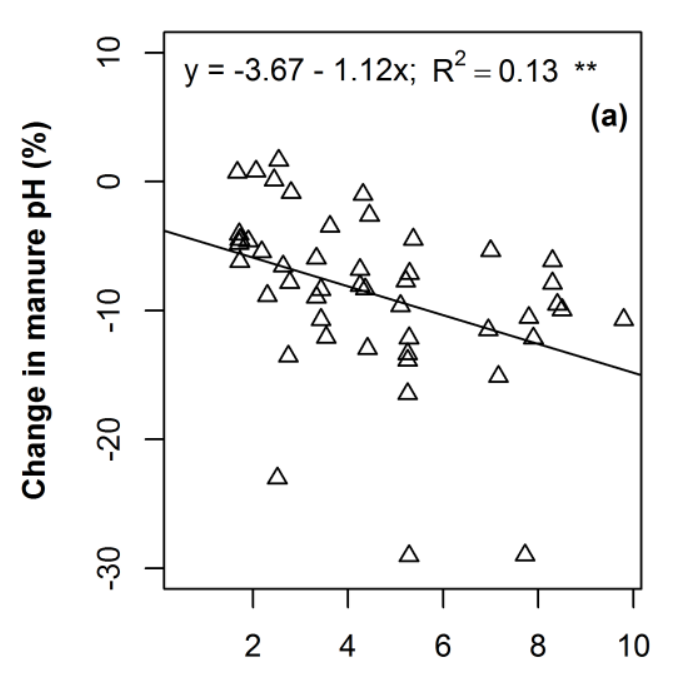

Reduction in dietary CP content (\%)

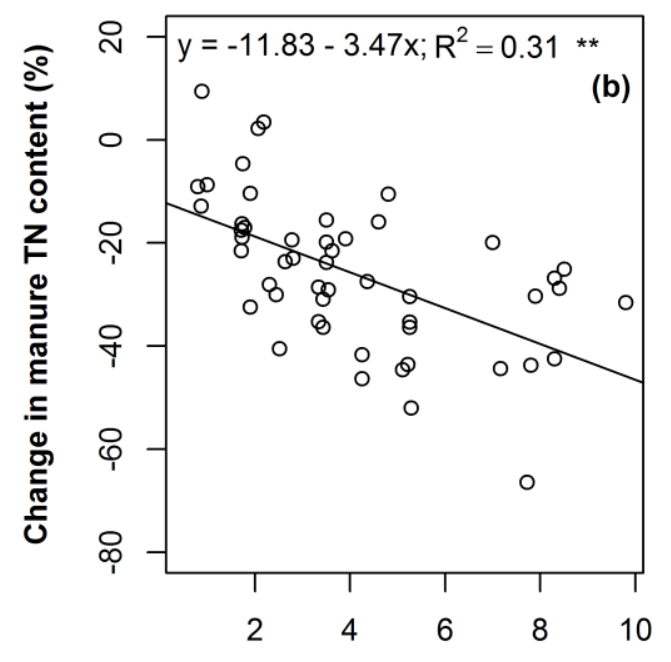

Reduction in dietary CP content (\%)

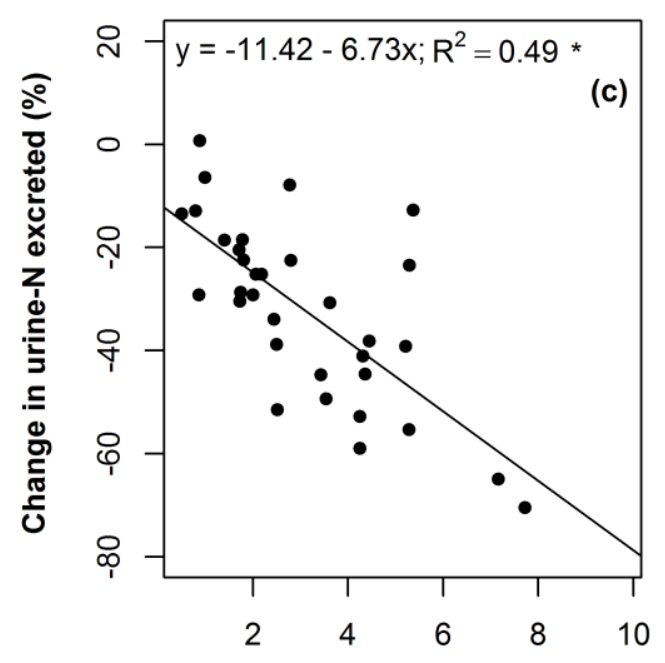

Reduction in dietary CP content (\%)

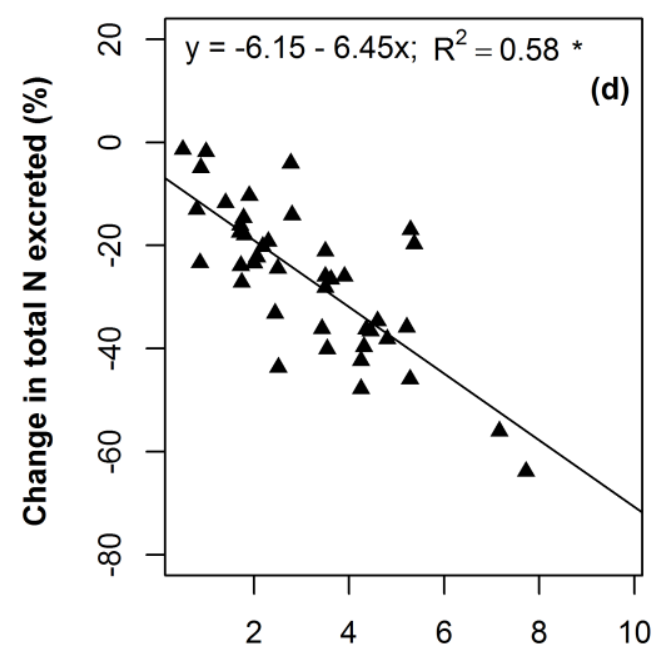

Reduction in dietary CP content (\%)

Figure 4-2. Relation between reduction in dietary $\mathrm{CP}$ content and change in manure $\mathrm{pH}$ (a), total $\mathrm{N}$ content of manure (b), urine-N excreted (c) and total (faeces and urine) $\mathrm{N}$ excreted (d), expressed as a percentage of the reference treatment. A CP reduction of $1 \%$ equals to $10 \mathrm{~g} \mathrm{CP}$ per kg DM-based feed. Significance asterisks $* *=P<0.01, *=P<0.05$.

A total of 9 studies (including 8 field-scale studies) were available to quantify the effect sizes of covers on $\mathrm{CH}_{4}$ and/or $\mathrm{N}_{2} \mathrm{O}$ emissions from slurry storage. Methane emissions were slightly suppressed by artificial film covers, but the effect was not statistically significant (Figure 4-3; 
$P>0.05)$. Similarly, for all other grouped side-by-side comparisons, the changes in $\mathrm{CH}_{4}$ emissions showed negative mean values. These effects were not statistically significant. Emissions of $\mathrm{N}_{2} \mathrm{O}$ were enhanced by a factor of 8.6 when stored slurry was covered by chopped straw $(P<0.01)$. By contrast, slurry covered with artificial film decreased $\mathrm{N}_{2} \mathrm{O}$ emissions by $98 \%(P<0.01)$.

\subsubsection{Emissions from solid manure storages - effects of compaction, stockpiling and covers}

Five studies conducted at pilot scales were available to compare side-by-side $\mathrm{NH}_{3}$ emissions from solid manure storages subjected to different treatments. Emissions of $\mathrm{NH}_{3}$ from compacted or covered manure heaps were on average $61 \%$ lower in comparison to manure heaps subjected to composting (i.e. turning over manure heaps regularly; Figure 4-1). Yet, these differences were not statistically significant $(P>0.05)$. Static piling of manure (i.e. without turnover or disturbance) yielded lower emissions compared to manure heaps subjected to composting $(P>0.05$; Figure 4-1). Apart from the meta-analysis, a number of additional studies without side-by-side comparisons were included in our database in order to maximize the number of studies for which $\mathrm{NH}_{3}$ emissions were recorded. Based on all studies reviewed, the median $\mathrm{NH}_{3}$ emission factor (\% of TN) for composting was 39\% (Table 4-3). Much lower emission factors were observed for static pilings (9\%), covered heaps (9\%) and compacted heaps $(12 \%)$.

A total of 6 pilot-scale studies were available for the analysis of the effect size of manure heap management on $\mathrm{CH}_{4}$ and $\mathrm{N}_{2} \mathrm{O}$ emissions. As illustrated in Figure 4-3, storage of solid manure subjected to compaction, covering or stockpiling had larger $\mathrm{CH}_{4}$ emissions than manure heaps subjected to composing; this difference was not significant. Compared to composting, two out of four studies reported significant higher $\mathrm{CH}_{4}$ emissions from stockpiling, whereas only one study found significant lower $\mathrm{CH}_{4}$ emissions from stockpiling. The effect sizes of these manure heap management practices on $\mathrm{N}_{2} \mathrm{O}$ emissions were found to be inconsistent and not statistically significant. 
(a)

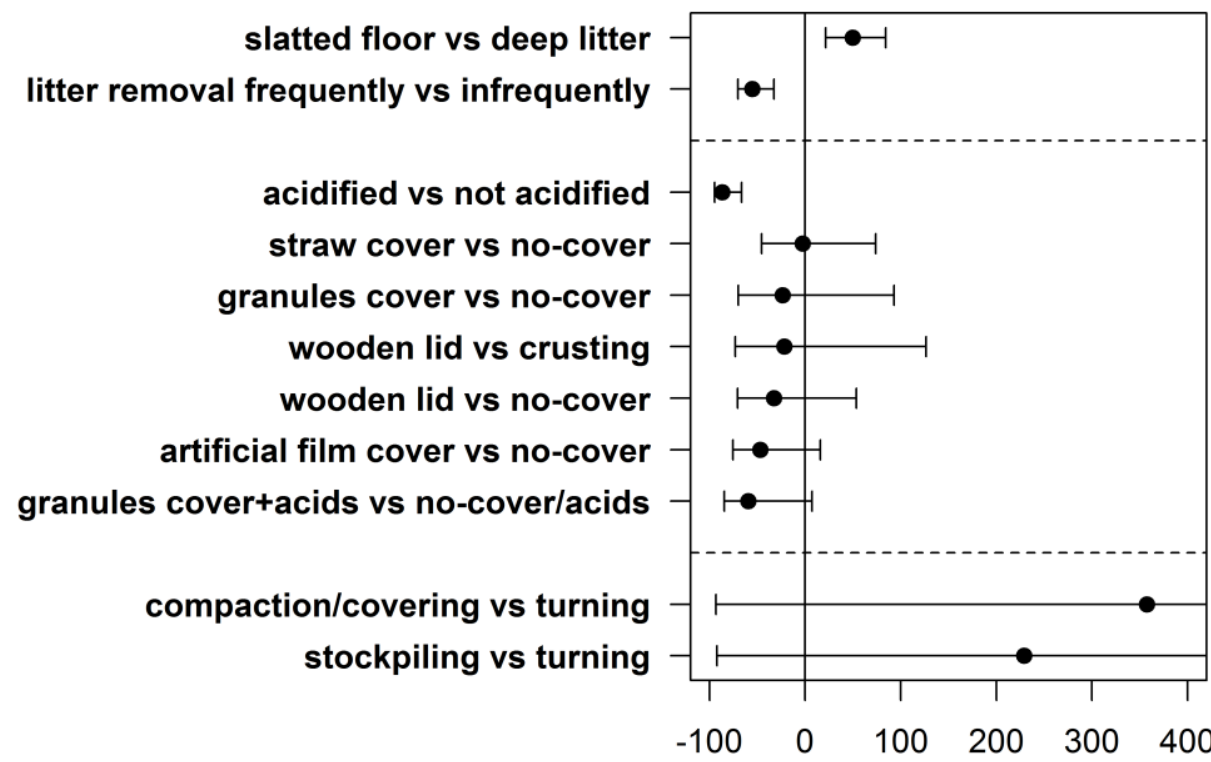

\section{Changes in methane emissions (\%)}

(b)

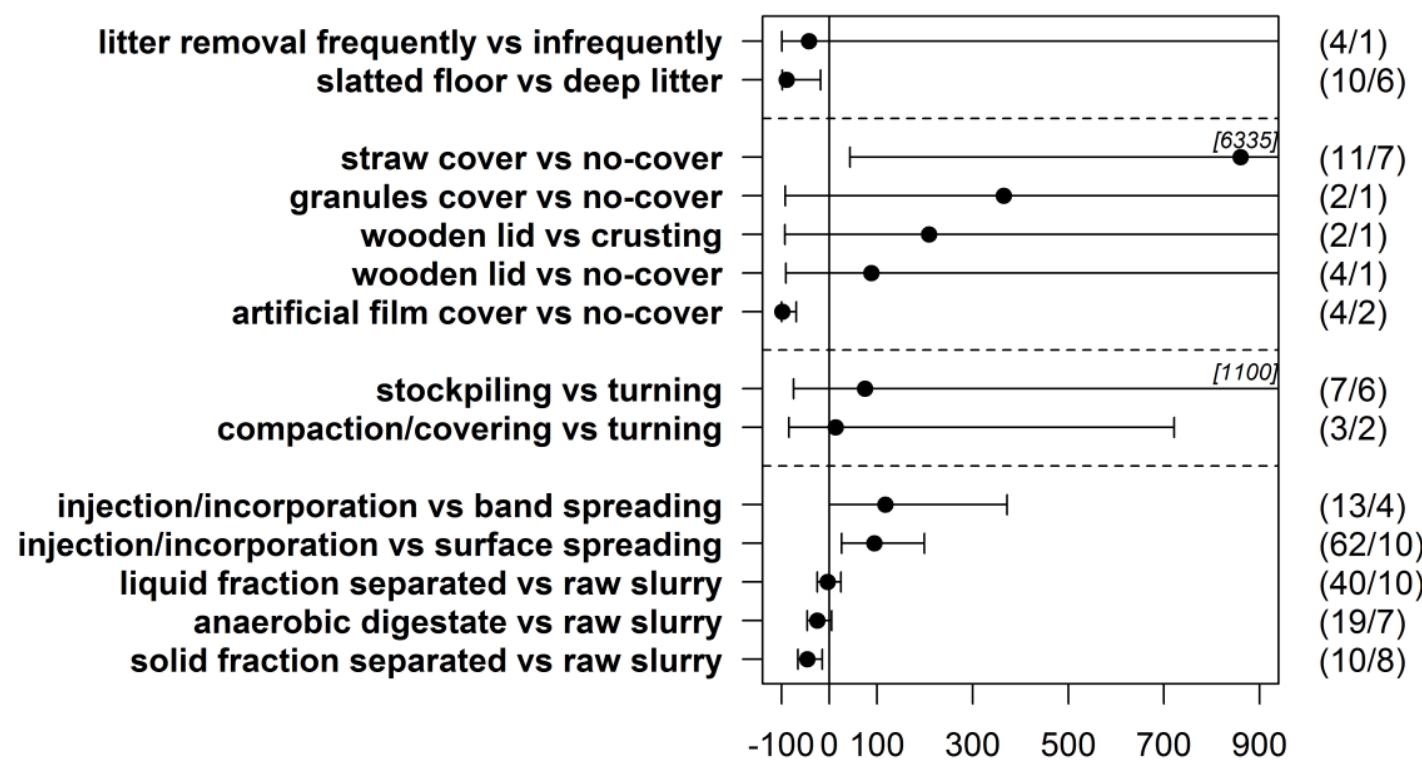

Changes in nitrous oxide emissions (\%)

Figure 4-3. The mean change in methane (a) and nitrous oxide (b) emissions as a percentage of the reference treatment, for a number of grouped side-by-side comparisons between treatments with vs without mitigation measures. Points show means of treatments, bars show $95 \%$ confidence intervals. The maximum values that exceed the scale of $\mathrm{x}$-axis are shown in brackets; some large variances (4-5 orders of magnitude) derived from limited studies are not shown. Numbers in the parentheses indicate the number of observations on which the statistical analysis was based, and the number of different studies from which the observations originated. 
Table 4-3. Emission factors of ammonia from storage of solid manure and field application of manure.

\begin{tabular}{lllll}
\hline Management stages & Management & \multicolumn{2}{l}{ Ammonia emission factors } & Range $^{\mathrm{b}}$ \\
\cline { 2 - 4 } & practices & Unit & Median $^{\mathrm{a}}$ & $17.3-45.3$ \\
Solid manure storage & Composting & \% of total N into & $38.9(26 / 8)$ & $1.8-23.5$ \\
& Stockpiling & storage & $9.0(15 / 9)$ & $1.1-17.4$ \\
& Compaction & & $12.4(4 / 3)$ & $8.3-15.2$ \\
\multirow{5}{*}{ Field application } & Covering & & $9.0(4 / 4)$ & $30.0-68.1$ \\
& Surface spreading & \% of total & $47.7(229 / 20)$ & $13.5-31.5$ \\
& Band spreading & ammoniacal N & $20.9(100 / 11)$ & $8.0-35.5$ \\
& Incorporation & applied & $21.0(39 / 5)$ & $4.9-21.2$ \\
\hline
\end{tabular}

${ }^{a}$ Numbers in the parentheses indicate the number of observations/studies; Data were derived from the references shown in Table1 and some additional studies referring storage of solid manure (Martins \& Dewes, 1992; Petersen et al., 1998; Sommer, 2001; Parkinson, 2004; Chadwick, 2005; Paillat et al., 2005; Hansen et al., 2006) and field application (Sommer \& Olesen, 1991; Menzi et al., 1998; Hansen et al., 2003; Amon et al., 2006; Chantigny et al., 2007; Balsari et al., 2008; Moal et al., 2009; Dinuccio et al., 2011, 2012; Huijsmans \& Hol, 2011; Nyord et al., 2012); These additional studies are not included in this meta-analysis.

${ }^{\mathrm{b}}$ Range from first quartile to third quartile

\subsubsection{Emissions after field application - effects of application methods and of processed manure products}

Side-by-side comparisons of $\mathrm{NH}_{3}$ emissions from manure following different application approaches were analysed based on results exclusively from field experiments. The emissions of $\mathrm{NH}_{3}$ from manures following band spreading, incorporation and injection were $55 \%$ (range: $37-67 \%), 70 \%(50-82 \%)$ and $80 \%(72-86 \%)$ lower than that from surface broadcasted manures, respectively (Figure 4-1). These differences were statistically significant $(P<0.01)$. Based on the reviewed studies, the median $\mathrm{NH}_{3}$ emission factor (in \% of TAN applied) for surface broadcasted manure was $48 \%$, compared to the emission factors of $21 \%, 21 \%$ and $11 \%$ for band spread, incorporated and injected manure, respectively (Table 4-3). A total of 75 observations (69 from field experiments) were available to analyse the effect sizes of application technologies on $\mathrm{N}_{2} \mathrm{O}$ emissions. Statistically higher emissions of $\mathrm{N}_{2} \mathrm{O}(98 \%)$ were found for injection/incorporation of manure compared with surface broadcasted manure $(P<$ 0.01) (Figure 4-3b).

Emissions of $\mathrm{NH}_{3}$ were not significantly different between digestates and raw slurry following field application (Figure 4-1; $P>0.05$ ). Significantly lower $\mathrm{NH}_{3}$ emissions (18\%) were found for separated liquid fraction (LFs) relative to raw slurry $(P<0.01$; Figure 4-1), based on 44 observations (41 from field experiments). The overall effect of LFs on $\mathrm{N}_{2} \mathrm{O}$ emissions did not differ from that of raw slurry (Figure 4-3b). Field-applied digestates and solid fractions showed on average 25\% $(P>0.05)$ and $46 \%(P<0.01)$ lower $\mathrm{N}_{2} \mathrm{O}$ emissions than field-applied untreated manure, respectively (Figure 4-3b). 


\section{Chapter 4}

\subsubsection{Emissions from manure management chains - effects of scenario analysis}

In the reference slurry-based system, emissions of $\mathrm{NH}_{3}$ from animal housing, external slurry storages and slurry application to the field amounted to $43 \%, 22 \%$ and $35 \%$ of the total emissions, respectively (Figure 4-4a). The assessment of single mitigation measures showed that the total $\mathrm{NH}_{3}$ emission was lowest (35\% of the reference) for the acidification scenario, followed by the low dietary $\mathrm{CP}$ scenario (65\% of the reference) and the slurry injection scenario ( $71 \%$ of the reference). Covering slurry storages with straw or an artificial film decreased $\mathrm{NH}_{3}$ emissions during storage, but increased emissions following land application (Figure 4-4a). The largest decrease in $\mathrm{NH}_{3}$ emissions was obtained when mitigation measures were combined (Figure 4-4a). Covering slurry storage with straw did not change the overall GHG emissions from the management chain (Figure 4-4b); the increased direct $\mathrm{N}_{2} \mathrm{O}$ emissions were offset by decreased indirect $\mathrm{N}_{2} \mathrm{O}$ and $\mathrm{CH}_{4}$ emissions during storage. The "injection" scenario showed a higher total GHG emissions than the reference scenario (by $16 \%$ ). Lowering dietary CP content decreased the whole-chain GHG emissions by $5 \%$. Use of an artificial film cover reduced GHG emissions with $24 \%$. The largest decrease (up to $50 \%$ ) was shown in the scenarios with slurry acidification (Figure 4-4b).

In the reference solid manure-based system, emissions of $\mathrm{NH}_{3}$ from housing, outdoor storages and following field application contributed to $38 \%, 25 \%$ and $37 \%$ of the total $\mathrm{NH}_{3}$ emissions (Figure 4-5a). Reducing dietary $\mathrm{CP}$ content decreased the $\mathrm{NH}_{3}$ emissions from the whole solid manure system by $29 \%$. Emissions of $\mathrm{NH}_{3}$ following the field application of stockpiled and compacted manures were higher than in the reference situation, suggesting that $\mathrm{NH}_{3}-\mathrm{N}$ trapped by low-emission techniques during storage escaped at subsequent stages (i.e. during field application). Lowering dietary $\mathrm{CP}$ content of the animal feed and direct incorporation of manure into the soil decreased $\mathrm{NH}_{3}$ emissions from stockpiled and compacted manures (Figure 4-5a). Direct $\mathrm{N}_{2} \mathrm{O}$ emissions were relatively large in the solid manure-based systems (Figure 4-5b). The "Diet" scenario was the only scenario that had lower GHG emissions than the reference (by 15\%), due to reduction in both direct and indirect $\mathrm{N}_{2} \mathrm{O}$ emissions. The GHG emissions in scenarios with stockpiling, compaction or manure incorporation were higher than that in the reference system. The highest GHG emissions were found for combined stockpiling and incorporation (Figure 4-5b).

Introducing separation techniques in slurry-based systems did not affect total emissions of $\mathrm{NH}_{3}$ and GHG much (Figure 4-6). This is due to the fact that decreased $\mathrm{CH}_{4}$ emissions were 
counterbalanced by increased $\mathrm{N}_{2} \mathrm{O}$ emissions. Centrifugation-based systems tended to have higher GHG emissions compared to systems with screw press (Figure 4-6b), which is related to differences in separation efficiencies. Emissions of GHG were reduced by a combination of low dietary CP level (7-10\% reduction) and covering storages of LFs (6-20\%).

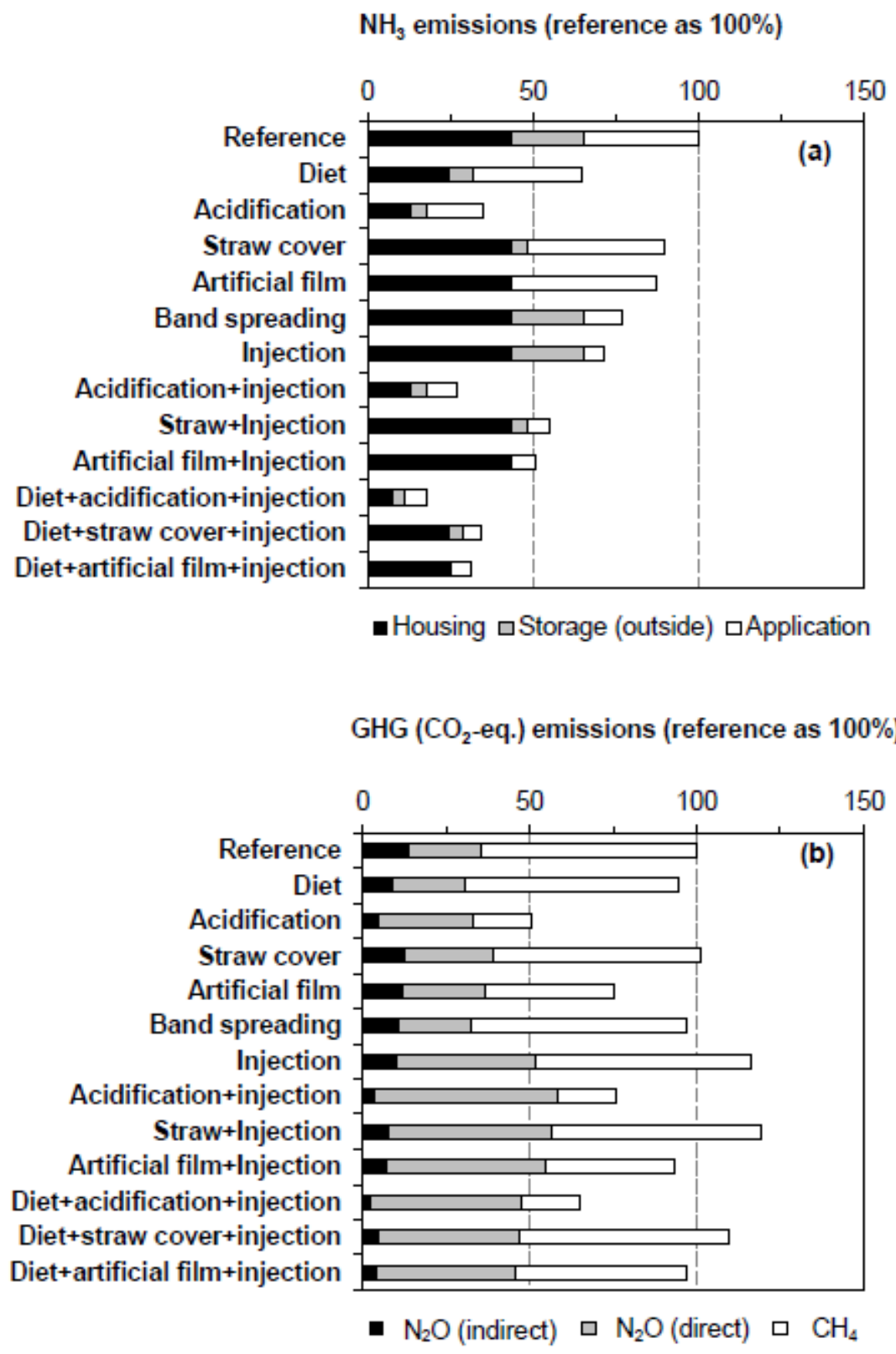

Figure 4-4. Impacts of mitigation measures on $\mathrm{NH}_{3}$ (a) and GHG (b) emissions from slurry-based systems, expressed as percentage of the reference system. See Table 4-2 for description of scenarios. 


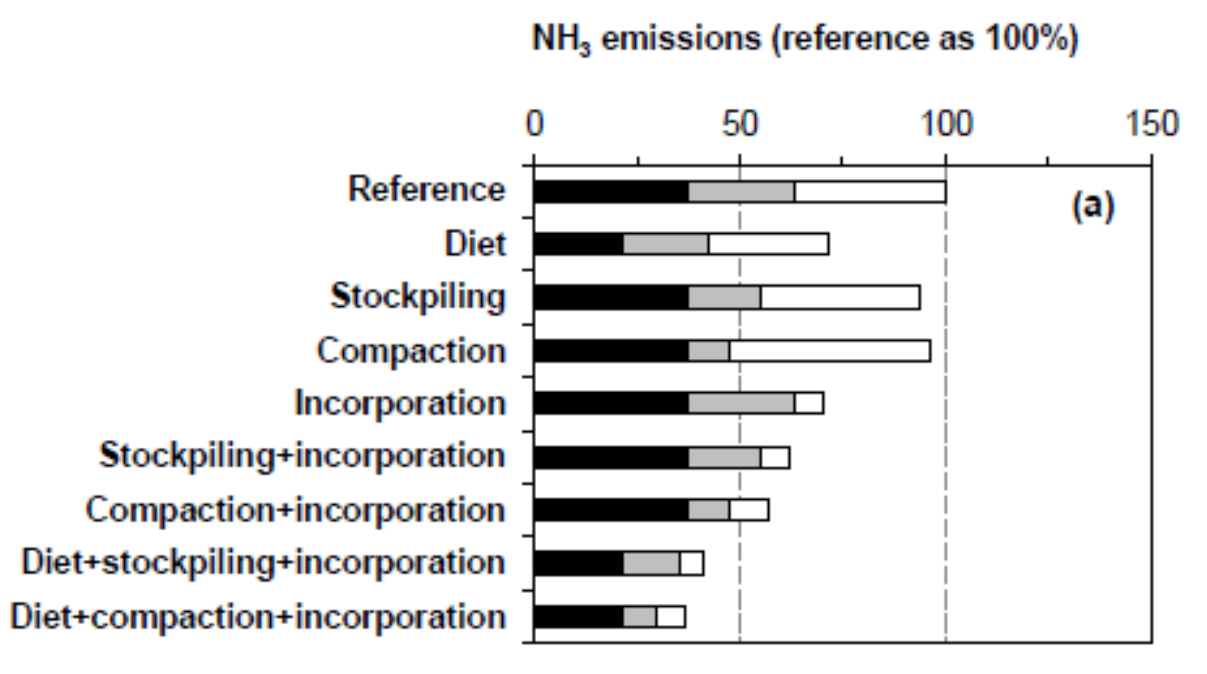

- Housing $\quad$ SStorage (outside) $\square$ Application

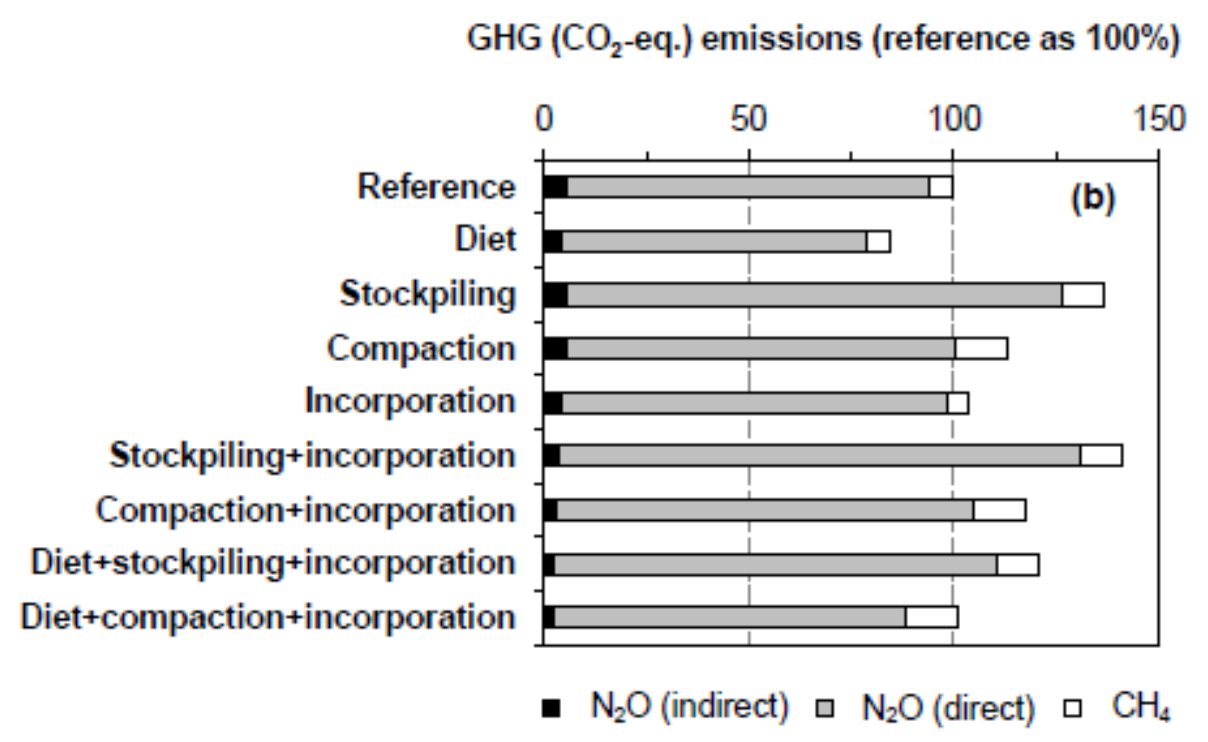

Figure 4-5. Impacts of mitigation measures on $\mathrm{NH}_{3}$ (a) and GHG (b) emissions from solid manurebased systems, expressed as percentage of the reference system. See Table 4-2 for description of scenarios. 

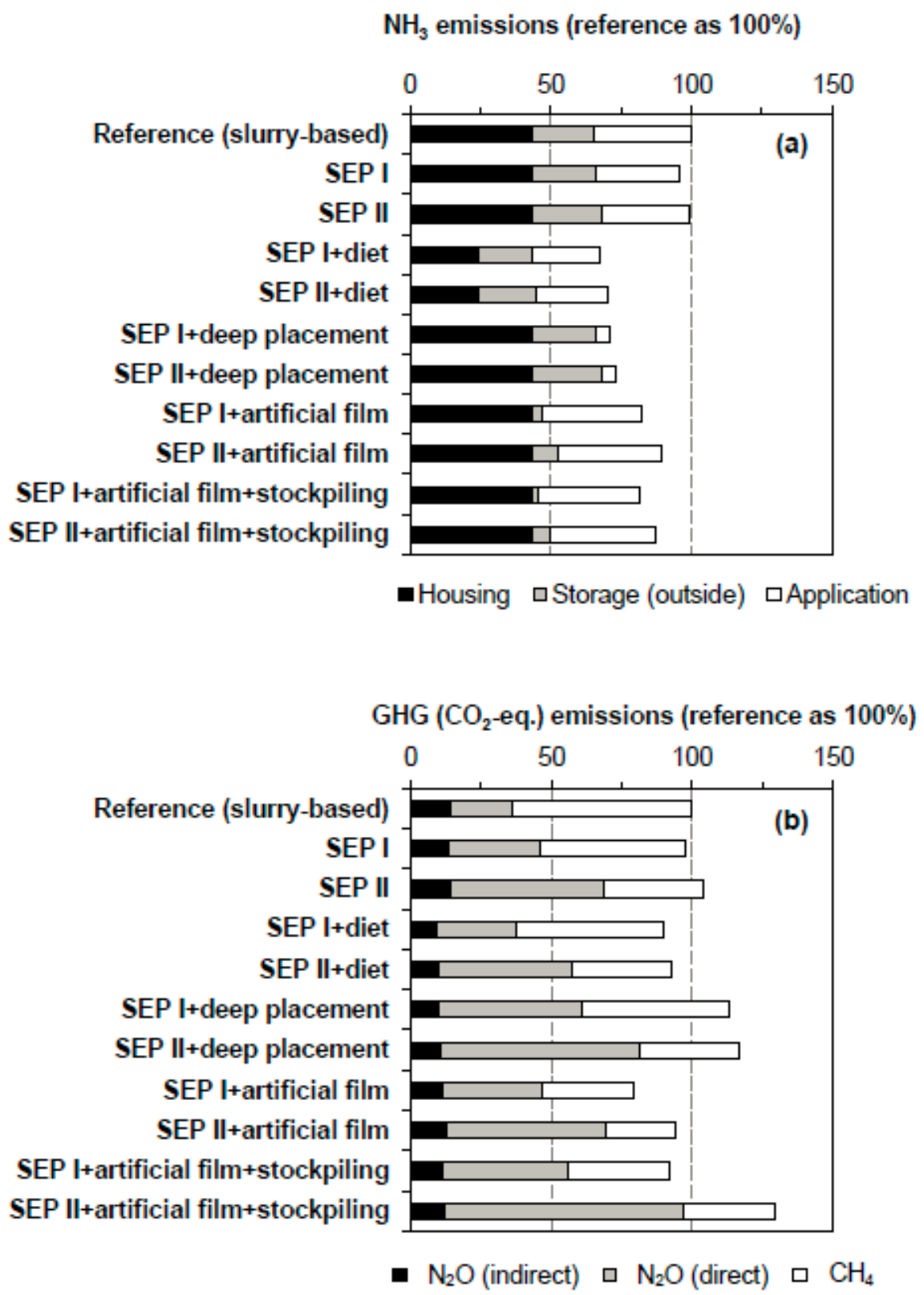

Figure 4-6. Impacts of mitigation measures on $\mathrm{NH}_{3}$ (a) and GHG (b) emissions from slurry separation-inclusive systems, expressed as percentage of the reference (i.e. slurry-based) system. SEP I and SEP II respectively indicate screw press and centrifuge separation. See Table 4-2 for description of scenarios. 


\section{Chapter 4}

\subsection{Discussion}

\subsubsection{Main findings}

This study quantitatively assessed the impacts of $\mathrm{NH}_{3}$ mitigation measures on emissions of $\mathrm{NH}_{3}, \mathrm{~N}_{2} \mathrm{O}$ and $\mathrm{CH}_{4}$ at individual stages of the manure management chain by means of a metaanalysis of 126 published studies. In addition, an integrated assessment of the impacts of packages of measures on $\mathrm{NH}_{3}$ and $\mathrm{GHG}$ emissions from the whole management chains was carried out using various scenarios for slurry-based and solid manure-based systems. The main findings of our study are as follows: (i) lowering the $\mathrm{CP}$ content in feed significantly decreased $\mathrm{NH}_{3}$ emissions at the housing stage (Figure 4-1) and also decreased the total GHG emissions from manure chains (Figures. 4-4,5,6), (ii) slurry acidification significantly decreased emissions of $\mathrm{NH}_{3}$ and $\mathrm{CH}_{4}$ from slurry storages (Figure 4-3), which leads to decreases in total GHG emissions from systems with acidified slurry (Figure 4-4b), (iii) covering slurry storages with straw significantly decreased $\mathrm{NH}_{3}$ emissions (Figure 4-1) and increased $\mathrm{N}_{2} \mathrm{O}$ emissions (Figure 4-3b), but the effects on total GHG emissions from the manure chains were relatively small (Figure 4-4b), (iv) stockpiling tended to decrease $\mathrm{NH}_{3}$ emissions (Figure 4-1), yet might enhance emissions of $\mathrm{N}_{2} \mathrm{O}$ and $\mathrm{CH}_{4}$ during storage (Figure 4-3) and total GHG emissions (Figure 4-5b), (v) injection or direct incorporation of manure into soil significantly decreased $\mathrm{NH}_{3}$ emissions (Figure 4-1), but significantly increased $\mathrm{N}_{2} \mathrm{O}$ emissions (Figure 4-3b) and total GHG emissions from the manure management chain (Figures 4-6), (vi) the packages of $\mathrm{NH}_{3}$ mitigation measures were effective in $\mathrm{NH}_{3}$ emission mitigation, but had only minor impacts on GHG emissions, with the exception of acidification and stockpiling, and (vii) the manure $\mathrm{N}$ that is conserved by using mitigation measures can be used as crop available $\mathrm{N}$, when low-emission field application techniques are applied.

The results collected did not allow to compare management options across animal species (e.g. pigs vs cattle). However, sufficient data were available for analysing the effects of lowering the $\mathrm{CP}$ content of feed for different animal species on $\mathrm{NH}_{3}$ emissions during housing and following slurry injection. The results indicate that the differences between animal species in emission reduction were not significant $(P>0.05$; data not shown). Data from both field-and laboratory-scale studies were included in our database as data solely from field-scale studies were insufficient. All data used in the meta-analysis is available as supporting information (Table S3). This database is expected to be updated in the future when new data especially from field-scale studies becomes available. 


\subsubsection{Dietary CP manipulation}

Clearly, lowering $\mathrm{CP}$ content in animal feed is an effective strategy to reduce $\mathrm{NH}_{3}$ emissions in the entire management chain (Figures 4-4,5,6). Lowering dietary $\mathrm{CP}$ deceases the $\mathrm{N}$ content of animal excreta. This is more pronounced for urine than for faeces (Figure 4-2). Urinary $\mathrm{N}$ is mainly in the form of urea and is easily converted into $\mathrm{NH}_{3}$ by the enzyme urease present in faeces (Smits et al., 1995; Canh et al., 1998a; Misselbrook et al., 2005a; Galassi et al., 2010). Lowering feed CP also decreases the pH of the manure (Figure 4-2a), which decreases the risk of $\mathrm{NH}_{3}$ emissions. This decrease in $\mathrm{pH}$ is likely related to a decreased dietary electrolyte balance, to changes in the concentration of volatile fatty acids (VFA), and to a decreased acetic acid/ propionic acid ratio in the manure (Canh et al., 1998b; Leek et al., 2005; Velthof et al., 2005; Hernández et al., 2011). Caution must be taken to maintain animal performance when dietary CP manipulation is implemented (Frank \& Swensson, 2002; Panetta et al., 2006). When necessary, essential amino acids should be supplemented in accordance with animal requirements. The perspectives for lowering dietary CP also depend on the current diet (Bittman et al., 2014). According to our database, a 0.5-2\% reduction in dietary CP was implemented for diets with a mean CP content of $14.4 \%$ (on a DM-basis), while a $4 \%$ reduction was implemented for diets with a mean $\mathrm{CP}$ content of $18.1 \%$.

The effects of dietary $\mathrm{CP}$ manipulation on $\mathrm{CH}_{4}$ and $\mathrm{N}_{2} \mathrm{O}$ emissions from animal excreta in housings were not quantitatively evaluated in the meta-analysis, as there were insufficient results. Montalvo et al. (2013) showed that reducing CP contents of pig diets decreased $\mathrm{CH}_{4}$ emissions from manure, but did not significantly affect $\mathrm{N}_{2} \mathrm{O}$ emissions. This is in agreement with the results of Velthof et al. (2005), who showed that the emission of $\mathrm{CH}_{4}$ had significant correlations with the contents of dry matter, total C and VFAs in the manure. However, Le et al. (2009) and Lee et al. (2012) reported no significant impacts on $\mathrm{CH}_{4}$ and $\mathrm{N}_{2} \mathrm{O}$ emissions when low CP diets were used. Clark et al. (2005) found increased emissions of $\mathrm{CH}_{4}$ from manure with decreasing dietary $\mathrm{CP}$ contents, presumably due to a slight reduction in digestibility of fibre that is the main substrate for methanogenesis with low $\mathrm{CP}$ contents (Külling et al., 2001). The impacts of reducing dietary CP contents on enteric $\mathrm{CH}_{4}$ emissions were reviewed recently by Dijkstra et al. (2011). They found no consistent effect of lowering dietary $\mathrm{CP}$ content on enteric $\mathrm{CH}_{4}$ emission. The scenario analysis showed that lowering the CP content in feed decreased $\mathrm{NH}_{3}$ and $\mathrm{N}_{2} \mathrm{O}$ emissions from the whole management chains (Figures 4-4,5,6). This decrease is partly due to less $\mathrm{N}$ in manure and partly also because of a 


\section{Chapter 4}

decrease in the $\mathrm{pH}$ of the manure. Decreasing the dietary $\mathrm{CP}$ content turned out to be a most promising strategy for abating N-based emissions.

\subsubsection{Housing structure}

The floor construction in animal houses has a significant effect on $\mathrm{NH}_{3}$ emissions from indoor-stored manure (Groot Koerkamp et al., 1998), partly because floor types might cause differences in micro-condition of manure storage. Animal houses with slatted floors or deep litter showed lower emissions than traditional houses with solid (concrete) floors (Figure 4-1). This is because urine as main source of $\mathrm{NH}_{3}$ can be drained off quickly via openings of slatted floor into the relatively cool underground storage with low airflow or can be absorbed by deep straw (Kavolelis, 2006). Livestock housing with V-shaped solid floors with a gutter at the bottom of the V-groove to drain urine have low $\mathrm{NH}_{3}$ emissions (Swierstra et al., 1995; Braam et al., 1997). The effectiveness of housing structure and management such as use of bedding on $\mathrm{NH}_{3}$ mitigation may vary depending on environmental conditions. Significant relationships between $\mathrm{NH}_{3}$ emissions and various climatic factors, such as outside temperature and wind speed, have been frequently reported for naturally ventilated dairy housings and pig buildings (Ivanova-Peneva et al., 2008; Pereira et al., 2010a; Schrade et al., 2012; Wu et al., 2012; Van Ransbeeck et al., 2013; Saha et al., 2014).

The emissions of $\mathrm{N}_{2} \mathrm{O}$ from a deep-litter house were significantly higher compared to those from a slatted-floor house (Figure 4-3b). The formation of $\mathrm{N}_{2} \mathrm{O}$ occurs during nitrification and denitrification processes. Nitrification requires aerobic conditions and denitrification requires anaerobic conditions. Both conditions can be found in deep-litter but not in slurries underneath slatted floors (Cabaraux et al., 2009). Emissions of $\mathrm{N}_{2} \mathrm{O}$ from housings without bedding materials are often hard to detect (Ngwabie et al., 2009, 2011; Wu et al., 2012; Saha et al., 2014). More attention should be given to deep-litter induced $\mathrm{N}_{2} \mathrm{O}$ emissions, particularly in the case of countries where adding bedding materials in housings is increasingly considered as a means to improve animal welfare. Conversely to $\mathrm{N}_{2} \mathrm{O}, \mathrm{CH}_{4}$ emissions were significantly higher in housings with slatted floors and underground slurry stores than in housings with deep litter (Figure 4-3a). The anaerobic conditions and the moderate $\mathrm{pH}$ level of slurry under slatted floor favour $\mathrm{CH}_{4}$ production. A high straw - manure ratio inhibits $\mathrm{CH}_{4}$ production because of a greater manure aeration (Philippe et al., 2011).

\subsubsection{Acidification}


Slurry acidification has been approved as a Best Available Technology (BAT) and is widely adopted in Denmark now (Petersen et al., 2012). The slurry is acidified in a process tank by controlled addition of sulphuric acid to a $\mathrm{pH}$ of about 5.5. The acidified slurry is pumped back to the slurry pit in the animal house or to outdoor storage tanks (Petersen et al., 2012). Such acidification technology has potential to reduce $\mathrm{NH}_{3}$ emission from housing, storage and field application (Kai et al., 2008). The $\mathrm{pH}$ of the slurry is a key factor affecting $\mathrm{NH}_{3}$ mitigation potential. The effectiveness of acidification to mitigate $\mathrm{NH}_{3}$ emissions is significantly weakened when the $\mathrm{pH}$ of the acidified slurry goes up to a level of 6.0-6.5 (Dai \& BlanesVidal, 2013; Petersen et al., 2014; Wang et al., 2014). Therefore, a pH of 6.0 is recommended as the upper limit for a successful emission abatement. There is limited information on emissions after land application of acidified slurry. Recent field experiments have shown that acidification results in a long-term inhibition of $\mathrm{CH}_{4}$ emissions from slurry storages (Petersen et al., 2014). The reduction in $\mathrm{CH}_{4}$ emissions could be attributed to inhibited methanogenesis because of the acidic conditions and high sulphide concentrations (Ottosen et al., 2009; Petersen et al., 2012). High sulphide concentrations may impair indoor air quality and animal performance. Because emissions of both $\mathrm{NH}_{3}$ and $\mathrm{CH}_{4}$ were decreased by acidification, the overall GHG emissions from acidified slurry were low (Figure 4-4b). Acidification of slurry to $\leq 6.0$ is therefore a possible technique to minimizing $\mathrm{GHG}$ emissions from slurries.

\subsubsection{Natural surface crust and artificial covers}

Formation of a natural surface crust on stored manure is known to be effective in reducing $\mathrm{NH}_{3}$ emissions during slurry storage. Crusting is enhanced by gasification, i.e., the release of gases, including $\mathrm{CO}_{2}$ and $\mathrm{CH}_{4}$ during anaerobic storage. During this process bubbles tend to combine around fibre particles, helping to raise floating particles to the surface (Smith et al., 2007). A limiting factor of generating a slurry crust is the dry matter content in slurry, and no crust is formed when the dry matter content is less than 1\% (Misselbrook et al., 2005a). The dry matter content is also influenced by diet ingredients and manure treatment such as slurry separation (Misselbrook et al., 2005a; Dinuccio et al., 2008; Fangueiro et al., 2008b). The ammonia mitigation potential is larger with artificial covers than with natural crusts (Figure 41). Artificial covers minimize the emitting surface and may adsorb ammonia (Hörnig et al., 1999; Portejoie et al., 2003). The effects depend on environmental conditions (Sommer, 1997). Emissions of $\mathrm{NH}_{3}$ were higher in summertime than in wintertime, and such temperature effect seems to be more pronounced for slurry without crust and cover (Balsari et al., 2006; Clemens et al., 2006; Petersen et al., 2013). 


\section{Chapter 4}

The published impacts of artificial covers and natural crusts on $\mathrm{CH}_{4}$ emissions during slurry storage are inconsistent (Figure 4-3a). Husted (1994) indicated that a natural surface crust reduced $\mathrm{CH}_{4}$ emission from slurry by a factor of $11-12$, although this effect decreased with increasing slurry temperature. A $38 \%$ decrease of $\mathrm{CH}_{4}$ emissions was reported by Sommer et al. (2000) when slurry was covered by a natural surface crust, or straw or floating Leca ${ }^{\circledR}$ (lightweight expanded clay aggregate). This reduction in $\mathrm{CH}_{4}$ emissions was related to the oxidation of $\mathrm{CH}_{4}$ in the surface crusts (Petersen et al., 2005; Petersen \& Ambus, 2006). However, Clemens et al. (2006) and Petersen et al. (2013) did not find a significant influence on $\mathrm{CH}_{4}$ emissions by covering slurry with straw. Berg et al. (2006) reported relatively high emission from slurry covered with straw, perlite or Leca ${ }^{\circledR}$ compared to uncovered slurry. Methane emissions are known to be highly dependent on ambient air temperature or slurry temperature (Husted, 1994; Sommer et al., 2000, 2007), which results in seasonal variations in $\mathrm{CH}_{4}$ emissions. The magnitude of such seasonal variations are dependent on many factors including manure characteristics, environmental conditions, and management practices (Clemens et al., 2006; Rodhe et al., 2012; Petersen et al., 2013).

Straw covers significantly increased emissions of $\mathrm{N}_{2} \mathrm{O}$ from slurry storages (Figure 4-3b). This may be due to an interface between the slurry and the air-filled surface covers, which favours both nitrification and denitrification (Sommer et al., 2000; Petersen et al., 2013). However, there were no significant differences in the overall GHG emissions between systems with or without straw covers (Figure 4-4b), because of the reduction of $\mathrm{NH}_{3}$ emissions and associated indirect $\mathrm{N}_{2} \mathrm{O}$ emissions. The variation in straw cover-induced $\mathrm{N}_{2} \mathrm{O}$ emissions was large (Figure 4-3b), which is partly related to variations in environmental conditions. There is evidence that increases in $\mathrm{N}_{2} \mathrm{O}$ emissions from slurry storage with covers (especially, surface crust and chopped straw) are more pronounced in summer than in winter (Sommer et al., 2000; Berg et al., 2006; Rodhe et al., 2012; Petersen et al., 2013).

\subsubsection{Stockpiling, compaction and covering}

Composting is considered as a good measure for recycling manure because it produces a stabilised and sanitised end-product for agriculture, with relatively low transport costs because of reduced volume and mass (Bernal et al., 2009). However, losses of $\mathrm{N}$ during composting can be high, especially via $\mathrm{NH}_{3}$ emissions (Figure 4-1) and are affected by the frequency of turning the manure heap (Sommer \& Dahl, 1999; Parkinson, 2004)(Martins \& Dewes, 1992). Methane emissions can be enhanced under anaerobic conditions in covered, 
compacted or static heaps compared to heaps subjected to turning (Figure 4-3a). However, $\mathrm{CH}_{4}$ emissions from heaps of solid manure with these alternative management measures are also (very) low, in case air temperature is relatively low (e.g. in winter) (Amon et al., 2001; Chadwick, 2005; Hansen et al., 2006). This indicates that measures to mitigate $\mathrm{CH}_{4}$ emissions from manure heaps should be especially implemented during warm seasons. Increases in $\mathrm{N}_{2} \mathrm{O}$ emissions during stockpiling (Figure 4-3b) increased GHG emissions from solid manurebased systems (Figure 4-5b). However, the mechanism behind the stockpiling-induced increase in $\mathrm{N}_{2} \mathrm{O}$ emission has not been well-studied and therefore requires further research (McGinn \& Sommer, 2007; Sagoo et al., 2007; Shah et al., 2012).

\subsubsection{Low-NH - -emission application technologies}

The calculated $\mathrm{NH}_{3}$ reduction efficiencies of low-emission field application techniques are well in agreement with the findings of Webb et al. (2010). Slurry injection has the highest $\mathrm{NH}_{3}$ mitigation potential (Figure 4-1). However, a side-effect of slurry injection is increased $\mathrm{N}_{2} \mathrm{O}$ emissions (Figure 4-3b). Such increases in $\mathrm{N}_{2} \mathrm{O}$ emissions are likely to increase the overall GHG emissions of the whole system when no combined mitigation measures (such as dietary CP manipulation and acidification) are applied (Figure 4-4b). The calculated effects of slurry injection or incorporation into the soil on $\mathrm{N}_{2} \mathrm{O}$ emissions were highly variable (Figure 4-3b) and related to many factors, e.g. types and application rates of manure, soil properties (e.g. soil texture and moisture content), vegetation and climate (Velthof et al., 2003). For example, Velthof \& Mosquera (2011) reported higher $\mathrm{N}_{2} \mathrm{O}$ emissions from injected manures than from surface-applied manures, but the effects were variable due to the large variations in soil moisture and rainfall. Webb et al. (2014) concluded that the impacts of immediate incorporation on $\mathrm{N}_{2} \mathrm{O}$ emissions may be related to soil type, with a greater possibility of emission increases on coarse sandy soils.

\subsubsection{Field application of processed manure}

The effect-size analysis of 44 side-by-side comparisons indicated that the liquid fraction of separated slurry had a significantly smaller $\mathrm{NH}_{3}$ emissions following application to land than untreated slurry (Figure 4-1). Most comparisons were made on manures applied via surface broadcasting (36 out of these comparisons). The lower $\mathrm{NH}_{3}$ emissions have been attributed to the low dry matter content in the liquid fraction that allows rapid infiltration of manure into soil (Bhandral et al., 2009; Dinuccio et al., 2012; Nyord et al., 2012). Infiltration into the soil reduces $\mathrm{NH}_{3}$ losses from surface applied slurry, partly because the rate of diffusion of $\mathrm{NH}_{3}$ in 


\section{Chapter 4}

the soil is relatively low, and the sorption of $\mathrm{NH}_{4}{ }^{+}$to soil colloids reduces the concentration of ammonium in the soil solution (Sommer \& Hutchings, 2001). The dry matter content in the liquid fraction may differ greatly between separation technologies and also because of the dry matter content in original slurry (Hjorth et al., 2010). Inefficient removal of solids from raw slurry may decrease the infiltration rate of the liquid fraction, which decreases the potential of lowering $\mathrm{NH}_{3}$ emissions from liquid fractions (Mattila et al., 2003; Dinuccio et al., 2011).

No significant difference in $\mathrm{N}_{2} \mathrm{O}$ emissions was observed between liquid factions and raw slurry following land application. Conversely, solid fractions have shown lower $\mathrm{N}_{2} \mathrm{O}$ emissions than raw slurry in terms of percentage of total $\mathrm{N}$ applied (Figure 4-3b). As the solid fraction contains less available $\mathrm{N}$ (particularly $\mathrm{NH}_{4}{ }^{+}$) than raw slurry, there is likely to be less nitrification and, by that, less emission of $\mathrm{N}_{2} \mathrm{O}$ (Fangueiro et al., 2007; Bertora et al., 2008). Slurry separation did not considerably influence the total $\mathrm{GHG}\left(\mathrm{CO}_{2}\right.$-eq.) emissions from the whole management chain (Figure 4-6b). Field application of digested substrates tended to have lower $\mathrm{N}_{2} \mathrm{O}$ emissions compared to raw slurry (Figure 4-3b). This is in agreement with the review of Nkoa (2013) in which the environmental risk of soil application of anaerobic digestates has been assessed. It has been hypothesized that the lower $\mathrm{N}_{2} \mathrm{O}$ emissions from digestates are the consequence of less easily degradable $\mathrm{C}$, hence less energy source for denitrifiers (Rochette et al., 2000; Vallejo et al., 2006).

\subsubsection{The manure management chain}

Our study provides a quantitative analysis of the effect sizes of a range of key manure management technologies on $\mathrm{NH}_{3}, \mathrm{~N}_{2} \mathrm{O}$ and $\mathrm{CH}_{4}$ emissions from the manure management chain. Lowering the dietary crude protein (CP) content of the animal feed and acidification of slurry in storages are management strategies that effectively reduced $\mathrm{NH}_{3}$ emissions and GHG emissions from all subsequent stages of the manure management chain (including both indirect and direct $\mathrm{N}_{2} \mathrm{O}$ emissions, and $\mathrm{CH}_{4}$ emissions). Strategies aimed at decreasing $\mathrm{NH}_{3}$ emissions from manure storages must be combined with low- $\mathrm{NH}_{3}$-emission manure application techniques, to ensure that the $\mathrm{NH}_{3}$ trapped during storage does not escape following field application. Slurry injection greatly decreases $\mathrm{NH}_{3}$ emissions but enhances $\mathrm{N}_{2} \mathrm{O}$ emissions. Joint adoption of slurry injection with a low dietary CP intake, and covering manure storages or acidification of slurry in storages greatly decreases the risk of pollution swapping. Compaction, static stockpiling and covering of solid manure tend to decrease $\mathrm{NH}_{3}$ emissions and increase $\mathrm{CH}_{4}$ and $\mathrm{N}_{2} \mathrm{O}$ emissions compared to manure heaps subjected to 
composting. However, the number of observations underlying these latter effects is low. Slurry separation in liquid and solid fractions does not significantly affect emissions of $\mathrm{NH}_{3}$ and GHG compared to a reference system without slurry separation. Given the possible synergistic and antagonistic effects, and the fact that mitigation measures are increasingly implemented in practice, selecting the proper combinations of measures becomes more important, in order to successfully minimize the whole-chain ammonia and GHG emissions.

\section{Acknowledgements}

The research leading to these results has received funding from the People Programme (Marie Curie Actions) of the European Union's Seventh Framework Programme FP7/20072013/under REA grant agreement no 289887. The results and conclusions achieved reflect only the author's view and the Union is not liable for any use that may be made of the information contained therein. O. Oenema and G.L Velthof were financially supported by the Interreg IVB NWE programme (project Biorefine) and the Dutch Ministry of Economic Affairs (BO-20-004-046). Assistance from PhD student Yang Yu, Wageningen University in statistical analysis is gratefully acknowledged.

\section{Supporting Information}

Additional Supporting Information can be found in the online version of this article:

http://onlinelibrary.wiley.com/doi/10.1111/gcb.12767/abstract 


\section{References}

Agle M, Hristov AN, Zaman S, Schneider C, Ndegwa P, Vaddella VK (2010) The effects of ruminally degraded protein on rumen fermentation and ammonia losses from manure in dairy cows. Journal of Dairy Science, 93, 1625-37.

Ahn HK, Mulbry W, White JW, Kondrad SL (2011) Pile mixing increases greenhouse gas emissions during composting of dairy manure. Bioresource Technology, 102, 2904-9.

Amon B, Amon T, Boxberger J, Alt C (2001) Emissions of $\mathrm{NH}_{3}, \mathrm{~N}_{2} \mathrm{O}$ and $\mathrm{CH}_{4}$ from dairy cows housed in a farmyard manure tying stall (housing, manure storage, manure spreading). Nutrient Cycling in Agroecosystems, 60, 103-113.

Amon B, Kryvoruchko V, Amon T, Zechmeister-Boltenstern S (2006) Methane, nitrous oxide and ammonia emissions during storage and after application of dairy cattle slurry and influence of slurry treatment. Agriculture, Ecosystems \& Environment, 112, 153-162.

Amon B, Kryvoruchko V, Fröhlich M, Amon T, Pöllinger A, Mösenbacher I, Hausleitner A (2007) Ammonia and greenhouse gas emissions from a straw flow system for fattening pigs: Housing and manure storage. Livestock Science, 112, 199-207.

Arriaga H, Salcedo G, Martínez-Suller L, Calsamiglia S, Merino P (2010) Effect of dietary crude protein modification on ammonia and nitrous oxide concentration on a tie-stall dairy barn floor. Journal of Dairy Science, 93, 3158-65.

Balsari P, Dinuccio E, Gioelli F (2006) A low cost solution for ammonia emission abatement from slurry storage. International Congress Series, 1293, 323-326.

Balsari P, Dinuccio E, Santoro E, Gioelli F (2008) Ammonia emissions from rough cattle slurry and from derived solid and liquid fractions applied to alfalfa pasture. Australian Journal of Experimental Agriculture, 48, 198.

Berg W, Brunsch R, Pazsiczki I (2006) Greenhouse gas emissions from covered slurry compared with uncovered during storage. Agriculture, Ecosystems \& Environment, 112, 129-134.

Bernal MP, Alburquerque JA, Moral R (2009) Composting of animal manures and chemical criteria for compost maturity assessment. A review. Bioresource Technology, 100, 5444-53.

Bertora C, Alluvione F, Zavattaro L, van Groenigen JW, Velthof G, Grignani C (2008) Pig slurry treatment modifies slurry composition, $\mathrm{N}_{2} \mathrm{O}$, and $\mathrm{CO}_{2}$ emissions after soil incorporation. Soil Biology and Biochemistry, 40, 1999-2006.

Bhandral R, Bittman S, Kowalenko G et al. (2009) Enhancing soil infiltration reduces gaseous emissions and improves $\mathrm{N}$ uptake from applied dairy slurry. Journal of Environmental Quality, $38,1372-82$.

Bittman S, Dedina M, Howard CM, Oenema O, Sutton MA (2014) Options for Ammonia Mitigation: Guidance from the UNECE Task Force on Reactive Nitrogen, Centre for Ecology and Hydrology, Edinburgh, UK.

Braam CR, Ketelaars JJ, Smits MCJ (1997) Effects of floor design and floor cleaning on ammonia emission from cubicle houses for dairy cows. Netherlands Journal of Agricultural Science, 45, 49-64.

Cabaraux J-F, Philippe F-X, Laitat M, Canart B, Vandenheede M, Nicks B (2009) Gaseous emissions from weaned pigs raised on different floor systems. Agriculture, Ecosystems \& Environment, 130, 86-92.

Canh TT, Aarnink AJA, Schutte JB, Sutton A, Langhout DJ, Verstegen MWA (1998a) Dietary protein affects nitrogen excretion and ammonia emission from slurry of growing-finishing pigs. Livestock Production Science, 56, 181-191. 
Canh TT, Aarnink AJ, Verstegen MW, Schrama JW (1998b) Influence of dietary factors on the pH and ammonia emission of slurry from growing-finishing pigs. Journal of Animal Science, 76, 1123-30.

Chadwick DR (2005) Emissions of ammonia, nitrous oxide and methane from cattle manure heaps: effect of compaction and covering. Atmospheric Environment, 39, 787-799.

Chadwick D, Sommer S, Thorman R, Fangueiro D, Cardenas L, Amon B, Misselbrook T (2011) Manure management: Implications for greenhouse gas emissions. Animal Feed Science and Technology, 166-167, 514-531.

Chantigny MH, Angers DA, Rochette P, Bélanger G, Massé D, Côté D (2007) Gaseous nitrogen emissions and forage nitrogen uptake on soils fertilized with raw and treated swine manure. Journal of Environmental Quality, 36, 1864-72.

Chantigny MH, MacDonald JD, Beaupré C, Rochette P, Angers DA, Massé D, Parent L-É (2009) Ammonia volatilization following surface application of raw and treated liquid swine manure. Nutrient Cycling in Agroecosystems, 85, 275-286.

Chiyoka WL, Hao X, Zvomuya F, Li X (2011) Nitrous oxide emissions from Chernozemic soils amended with anaerobically digested beef cattle feedlot manure: A laboratory study. Animal Feed Science and Technology, 166-167, 492-502.

Clark OG, Moehn S, Edeogu I, Price J, Leonard J (2005) Manipulation of dietary protein and nonstarch polysaccharide to control swine manure emissions. Journal of Environmental Quality, $34,1461-6$.

Clemens J, Trimborn M, Weiland P, Amon B (2006) Mitigation of greenhouse gas emissions by anaerobic digestion of cattle slurry. Agriculture, Ecosystems \& Environment, 112, 171-177.

Collins HP, AlvaAK, Streubel JD et al. (2011) Greenhouse gas emissions from an irrigated silt loam soil amended with anaerobically digested dairy manure. Soil Science Society of America Journal, $75,2206$.

Dai XR, Blanes-Vidal V (2013) Emissions of ammonia, carbon dioxide, and hydrogen sulfide from swine wastewater during and after acidification treatment: effect of $\mathrm{pH}$, mixing and aeration. Journal of Environmental Management, 115, 147-54.

Dijkstra J, Oenema O, Bannink A (2011) Dietary strategies to reducing N excretion from cattle: implications for methane emissions. Current Opinion in Environmental Sustainability, 3, 414 422.

Dinuccio E, Berg W, Balsari P (2008) Gaseous emissions from the storage of untreated slurries and the fractions obtained after mechanical separation. Atmospheric Environment, 42, 2448-2459.

Dinuccio E, Berg W, Balsari P (2011) Effects of mechanical separation on GHG and ammonia emissions from cattle slurry under winter conditions. Animal Feed Science and Technology, 166$167,532-538$.

Dinuccio E, Gioelli F, Balsari P, Dorno N (2012) Ammonia losses from the storage and application of raw and chemo-mechanically separated slurry. Agriculture, Ecosystems \& Environment, 153, 16 23.

Dourmad JY, Hassouna M, Robin P, Guingand N, Meunier-Salaün MC, Lebret B (2009) Influence of pig rearing system on animal performance and manure composition. Animal, 3, 606-16.

El Kader NA, Robin P, Paillat J-M, Leterme P (2007) Turning, compacting and the addition of water as factors affecting gaseous emissions in farm manure composting. Bioresource Technology, 98, 2619-28.

EMEP/EEA (2013) EMEP/EEA air pollutant emission inventory guidebook-2013. Available on: http://www.eea.europa.eu/publications/emep-eea-guidebook-2013 (accessed 06.06.2014). 


\section{Chapter 4}

Fangueiro D, Pereira J, Chadwick D, Coutinho J, Moreira N, Trindade H (2007) Laboratory assessment of the effect of cattle slurry pre-treatment on organic $\mathrm{N}$ degradation after soil application and $\mathrm{N}_{2} \mathrm{O}$ and $\mathrm{N}_{2}$ emissions. Nutrient Cycling in Agroecosystems, 80, 107-120.

Fangueiro D, Coutinho J, Chadwick D, Moreira N, Trindade H (2008a) Effect of cattle slurry separation on greenhouse gas and ammonia emissions during storage. Journal of Environmental Quality, 37, 2322-31.

Fangueiro D, Senbayran M, Trindade H, Chadwick D (2008b) Cattle slurry treatment by screw press separation and chemically enhanced settling: effect on greenhouse gas emissions after land spreading and grass yield. Bioresource Technology, 99, 7132-42.

Fangueiro D, Ribeiro H, Coutinho J et al. (2010) Nitrogen mineralization and $\mathrm{CO}_{2}$ and $\mathrm{N}_{2} \mathrm{O}$ emissions in a sandy soil amended with original or acidified pig slurries or with the relative fractions. Biology and Fertility of Soils, 46, 383-391.

Flessa H, Beese F (2000) Laboratory estimates of trace gas emissions following surface application and injection of cattle slurry. Journal of Environmental Quality, 29, 262-268.

Foged HL, Flotats X, Blasi AB, Palatsi J, Magri A, Schelde KM (2011) Inventory of manure processing activities in Europe. Technical Report No. I concerning "Manure Processing Activities in Europe" to the European Commission, Directorate-General Environment.

Frank B, Swensson C (2002) Relationship between content of crude protein in rations for dairy cows and milk yield, concentration of urea in milk and ammonia emissions. Journal of Dairy Science, 85, 1829-38.

Frank B, Persson M, Gustafsson G (2002) Feeding dairy cows for decreased ammonia emission. Livestock Production Science, 76, 171-179.

Galassi G, Colombini S, Malagutti L, Crovetto GM, Rapetti L (2010) Effects of high fibre and low protein diets on performance, digestibility, nitrogen excretion and ammonia emission in the heavy pig. Animal Feed Science and Technology, 161, 140-148.

Galloway JN, Dentener FJ, Capone DG et al. (2004) Nitrogen Cycles: Past, Present, and Future. Biogeochemistry, 70, 153-226.

Gilhespy SL, Webb J, Chadwick DR et al. (2009) Will additional straw bedding in buildings housing cattle and pigs reduce ammonia emissions? Biosystems Engineering, 102, 180-189.

Groenestein CM, Van Faassen HG (1996) Volatilization of ammonia, nitrous oxide and nitric oxide in deep-litter systems for fattening pigs. Journal of Agricultural Engineering Research, 65, 269274.

Groot Koerkamp PWG, Metz JHM, Uenk GH et al. (1998) Concentrations and emissions of ammonia in livestock buildings in Northern Europe. Journal of Agricultural Engineering Research, 70, 79-95.

Gurevitch J, Curtis P, Jones M (2001) Meta-analysis in ecology. Advances in Ecological Research, 32, 199-247.

Hansen MN, Sommer SG, Madsen NP (2003) Reduction of Ammonia Emission by Shallow Slurry Injection. Journal of Environment Quality, 32, 1099.

Hansen MN, Henriksen K, Sommer SG (2006) Observations of production and emission of greenhouse gases and ammonia during storage of solids separated from pig slurry: Effects of covering. Atmospheric Environment, 40, 4172-4181.

Hansen CF, Sørensen G, Lyngbye M (2007) Reduced diet crude protein level, benzoic acid and inulin reduced ammonia, but failed to influence odour emission from finishing pigs. Livestock Science, 109, 228-231.

Hansen RR, Nielsen DA, Schramm A, Nielsen LP, Revsbech NP, Hansen MN (2009) Greenhouse gas microbiology in wet and dry straw crust covering pig slurry. Journal of Environmental Quality, $38,1311-9$. 
Hao X, Chang C, Larney FJ, Travis GR (2001) Greenhouse gas emissions during cattle feedlot manure composting. Journal of Environmental Quality, 30, 376-86.

Hayes ET, Leek ABG, Curran TP, Dodd VA, Carton OT, Beattie VE, O'Doherty JV (2004) The influence of diet crude protein level on odour and ammonia emissions from finishing pig houses. Bioresource Technology, 91, 309-315.

Hernández F, Martínez S, López C, Megías MD, López M, Madrid J (2011) Effect of dietary crude protein levels in a commercial range, on the nitrogen balance, ammonia emission and pollutant characteristics of slurry in fattening pigs. Animal, 5, 1290-8.

Hjorth M, Christensen K V., Christensen ML, Sommer SG (2010) Solid-liquid separation of animal slurry in theory and practice. A review. Agronomy for Sustainable Development, 30, 153-180.

Hörnig G, Türk M, Wanka U (1999) Slurry Covers to reduce Ammonia Emission and Odour Nuisance. Journal of Agricultural Engineering Research, 73, 151-157.

Huijsmans J (2003) Effect of application method, manure characteristics, weather and field conditions on ammonia volatilization from manure applied to arable land. Atmospheric Environment, 37, 3669-3680.

Huijsmans M, Hol G (2011) Ammonia emission after application of mineral concentrate to arable land and grassland. In: Report Plant Research International 398 (ed. Huijsmans M), pp. 1-44 Wageningen UR, Wageningen, the Netherlands.

Huijsmans JFM, Hol JMG, Hendriks MMWB (2001) Effect of application technique, manure characteristics, weather and field conditions on ammonia volatilization from manure applied to grassland. NJAS - Wageningen Journal of Life Sciences, 49, 323-342.

Husted S (1994) Seasonal variation in methane emission from stored slurry and solid manures. Journal of Environmental Quality, 23, 585-592.

IPCC (2006) Guidelines for National Greenhouse Gas Inventories. Volume 4. Agriculture, Forestry and Other Land Use. Intergovern- mental Panel on Climate Change. IGES, Japan.

IPCC (2007) Climate Change 2007: The Physical Science Basis. Cambridge University Press, Cambridge, UK and New York, NY, USA.

Ivanova-Peneva SG, Aarnink AJA, Verstegen MWA (2008) Ammonia emissions from organic housing systems with fattening pigs. Biosystems Engineering, 99, 412-422.

James T, Meyer D, Esparza E, Depeters EJ, Perez-Monti H (1999) Effects of dietary nitrogen manipulation on ammonia volatilization from manure from Holstein heifers. Journal of Dairy Science, 82, 2430-9.

Jiang T, Schuchardt F, Li GX, Guo R, Luo YM (2013) Gaseous emission during the composting of pig feces from Chinese Ganqinfen system. Chemosphere, 90, 1545-51.

Kai P, Pedersen P, Jensen JE, Hansen MN, Sommer SG (2008) A whole-farm assessment of the efficacy of slurry acidification in reducing ammonia emissions. European Journal of Agronomy, $28,148-154$.

Kavolelis B (2006) Impact of animal housing systems on ammonia emission rates. Polish Journal of Environmental Studies, 15, 739-745.

Koenig KM, McGinn SM, Beauchemin KA (2013) Ammonia emissions and performance of backgrounding and finishing beef feedlot cattle fed barley-based diets varying in dietary crude protein concentration and rumen degradability. Journal of Animal Science, 91, 2278-94.

Külling DR, Menzi H, Kröber TF, Neftel A, Sutter F, Lischer P, Kreuzer M (2001) Emissions of ammonia, nitrous oxide and methane from different types of dairy manure during storage as affected by dietary protein content. The Journal of Agricultural Science, 137. 235-250.

Le PD, Aarnink AJA, Jongbloed AW, van der Peet-Schwering CMC, Ogink NWM, Verstegen MWA (2008) Interactive effects of dietary crude protein and fermentable carbohydrate levels on odour from pig manure. Livestock Science, 114, 48-61. 


\section{Chapter 4}

Le PD, Aarnink AJA, Jongbloed AW (2009) Odour and ammonia emission from pig manure as affected by dietary crude protein level. Livestock Science, 121, 267-274.

Lee C, Hristov AN, Dell CJ, Feyereisen GW, Kaye J, Beegle D (2012) Effect of dietary protein concentration on ammonia and greenhouse gas emitting potential of dairy manure. Journal of Dairy Science, 95, 1930-41.

Leek A, Callan J, Henry R, O'Doherty J (2005) Low crude protein wheat-soyabean diets to growing and finishing pigs: 2 . The effects on nutrient digestibility, nitrogen excretion, faecal volatile fatty acid concentration. Irish Journal of Agricultural and Food Research, 44, 247-260.

Leek ABG, Hayes ET, Curran TP, Callan JJ, Beattie VE, Dodd VA, O'Doherty J V (2007) The influence of manure composition on emissions of odour and ammonia from finishing pigs fed different concentrations of dietary crude protein. Bioresource Technology, 98, 3431-9.

Li L, Cyriac J, Knowlton KF, Marr LC, Gay SW, Hanigan MD, Ogejo JA (2009) Effects of reducing dietary nitrogen on ammonia emissions from manure on the floor of a naturally ventilated free stall dairy barn at low $\left(0-20^{\circ} \mathrm{C}\right)$ temperatures. Journal of Environmental Quality, 38, 2172-81.

Lynch MB, Sweeney T, Callan B Flynn JJ, O'Doherty J V (2007) The effect of high and low dietary crude protein and inulin supplementation on nutrient digestibility, nitrogen excretion, intestinal microflora and manure ammonia emissions from finisher pigs. Animal, 1, 1112-21.

Lynch MB, O'Shea CJ, Sweeney T, Callan JJ, O'Doherty J V (2008) Effect of crude protein concentration and sugar-beet pulp on nutrient digestibility, nitrogen excretion, intestinal fermentation and manure ammonia and odour emissions from finisher pigs. Animal, 2, 425-34.

Madrid J, Martínez S, López C, Orengo J, López MJ, Hernández F (2013) Effects of low protein diets on growth performance, carcass traits and ammonia emission of barrows and gilts. Animal Production Science, 53, 146-153.

Malgeryd J (1998) Technical measures to reduce ammonia losses after spreading of animal manure. Nutrient Cycling in Agroecosystems, 51, 51-57.

Martins O, Dewes T (1992) Loss of nitrogenous compounds during composting of animal wastes. Bioresource Technology, 42, 103-111.

Mattila P, Joki-Tokola E (2003) Effect of treatment and application technique of cattle slurry on its utilization by ley: I. Slurry properties and ammonia volatilization. Nutrient Cycling in Agroecosystems, 65, 221-230.

Mattila P, Joki-Tokola E, Tanni R (2003) Effect of treatment and application technique of cattle slurry on its utilization by ley: II. Recovery of nitrogen and composition of herbage yield. Nutrient Cycling in Agroecosystems, 65, 231-242.

McGinn SM, Sommer SG (2007) Ammonia emissions from land-applied beef cattle manure. Canadian Journal of Soil Science, 87, 345-352.

Menzi H, Katz PE, Fahrni M, Neftel A, Frick R (1998) A simple empirical model based on regression analysis to estimate ammonia emissions after manure application. Atmospheric Environment, 32, 301-307.

Misselbrook TH, Smith ka, Johnson RA, Pain BF (2002) Slurry application techniques to reduce ammonia emissions: results of some UK field-scale experiments. Biosystems Engineering, 81, 313-321.

Misselbrook TH, Powell JM, Broderick GA, Grabber JH (2005a) Dietary manipulation in dairy cattle: laboratory experiments to assess the influence on ammonia emissions. Journal of Dairy Science, $88,1765-77$.

Misselbrook TH, Brookman SKE, Smith KA, Cumby T, Williams AG, McCrory DF (2005b) Crusting of stored dairy slurry to abate ammonia emissions: pilot-scale studies. Journal of Environmental Quality, 34, 411-9. 
Moal J-F, Martinez J, Guiziou F, Coste C-M (2009) Ammonia volatilization following surface-applied pig and cattle slurry in France. The Journal of Agricultural Science, 125, 245.

Möller K, Stinner W (2009) Effects of different manuring systems with and without biogas digestion on soil mineral nitrogen content and on gaseous nitrogen losses (ammonia, nitrous oxides). European Journal of Agronomy, 30, 1-16.

Monaco S, Sacco D, Pelissetti S, Dinuccio E, Balsari P, Rostami M, Grignani C (2011) Laboratory assessment of ammonia emission after soil application of treated and untreated manures. The Journal of Agricultural Science, 150, 65-73.

Montalvo G, Morales J, Pineiro C, Godbout S, Bigeriego M (2013) Effect of different dietary strategies on gas emissions and growth performance in post- weaned piglets. Spanish Journal of Agricultural Research, 11, 1016.

Montes F, Meinen R, Dell C et al. (2013) Special topics--Mitigation of methane and nitrous oxide emissions from animal operations: II. A review of manure management mitigation options. Journal of Animal Science, 91, 5070-94.

Ngwabie NM, Jeppsson K-H, Nimmermark S, Swensson C, Gustafsson G (2009) Multi-location measurements of greenhouse gases and emission rates of methane and ammonia from a naturally-ventilated barn for dairy cows. Biosystems Engineering, 103, 68-77.

Ngwabie NM, Jeppsson K-H, Gustafsson G, Nimmermark S (2011) Effects of animal activity and air temperature on methane and ammonia emissions from a naturally ventilated building for dairy cows. Atmospheric Environment, 45, 6760-6768.

Nkoa R (2013) Agricultural benefits and environmental risks of soil fertilization with anaerobic digestates: a review. Agronomy for Sustainable Development, 34, 473-492.

Novak S, Fiorelli J (2010) Greenhouse gases and ammonia emissions from organic mixed crop-dairy systems: a critical review of mitigation options. Agronomy for Sustainable Development, 30, 215-236.

Nyord T, Hansen MN, Birkmose TS (2012) Ammonia volatilisation and crop yield following land application of solid-liquid separated, anaerobically digested, and soil injected animal slurry to winter wheat. Agriculture, Ecosystems \& Environment, 160, 75-81.

O'Connell JM, Callan JJ, O'Doherty JV (2006) The effect of dietary crude protein level, cereal type and exogenous enzyme supplementation on nutrient digestibility, nitrogen excretion, faecal volatile fatty acid concentration and ammonia emissions from pigs. Animal Feed Science and Technology, 127, 73-88.

O'Shea CJ, Lynch B, Lynch MB, Callan JJ, O'Doherty JV (2009) Ammonia emissions and dry matter of separated pig manure fractions as affected by crude protein concentration and sugar beet pulp inclusion of finishing pig diets. Agriculture, Ecosystems \& Environment, 131, 154-160.

Oenema O, Velthof G, Kuikman P (2001) Technical and policy aspects of strategies to decrease greenhouse gas emissions from agriculture. Nutrient Cycling in Agroecosystems, 1997, 301-315.

Oenema O, Wrage N, Velthof GL, Groenigen JW, Dolfing J, Kuikman PJ (2005) Trends in Global Nitrous Oxide Emissions from Animal Production Systems. Nutrient Cycling in Agroecosystems, 72, 51-65.

Ottosen LDM, Poulsen H V., Nielsen DA, Finster K, Nielsen LP, Revsbech NP (2009) Observations on microbial activity in acidified pig slurry. Biosystems Engineering, 102, 291-297.

Paillat J-M, Robin P, Hassouna M, Leterme P (2005) Predicting ammonia and carbon dioxide emissions from carbon and nitrogen biodegradability during animal waste composting. Atmospheric Environment, 39, 6833-6842.

Panetta DM, Powers WJ, Xin H, Kerr BJ, Stalder KJ (2006) Nitrogen excretion and ammonia emissions from pigs fed modified diets. Journal of Environmental Quality, 35, 1297-308. 


\section{Chapter 4}

Parkinson R (2004) Effect of turning regime and seasonal weather conditions on nitrogen and phosphorus losses during aerobic composting of cattle manure. Bioresource Technology, 91, 171-178.

Pereira J, Misselbrook TH, Chadwick DR, Coutinho J, Trindade H (2010a) Ammonia emissions from naturally ventilated dairy cattle buildings and outdoor concrete yards in Portugal. Atmospheric Environment, 44, 3413-3421.

Pereira J, Fangueiro D, Chadwick DR, Misselbrook TH, Coutinho J, Trindade H (2010b) Effect of cattle slurry pre-treatment by separation and addition of nitrification inhibitors on gaseous emissions and N dynamics: a laboratory study. Chemosphere, 79, 620-7.

Petersen S. (1999) Nitrous oxide emissions from manure and inorganic fertilizers applied to spring barley. Journal of Environmental Quality, 28, 1610-1618.

Petersen SO, Ambus P (2006) Methane oxidation in pig and cattle slurry storages, and effects of surface crust moisture and methane availability. Nutrient Cycling in Agroecosystems, 74, 1-11.

Petersen SO, Lind A-M, Sommer SG (1998) Nitrogen and organic matter losses during storage of cattle and pig manure. The Journal of Agricultural Science, 130, 69-79.

Petersen SO, Amon B, Gattinger A (2005) Methane oxidation in slurry storage surface crusts. Journal of Environmental Quality, 34, 455-61.

Petersen S, Sommer S, Beline F et al. (2007) Recycling of livestock manure in a whole-farm perspective. Livestock Science, 112, 180-191.

Petersen SO, Andersen AJ, Eriksen J (2012) Effects of cattle slurry acidification on ammonia and methane evolution during storage. Journal of Environmental Quality, 41, 88-94.

Petersen SO, Dorno N, Lindholst S, Feilberg A, Eriksen J (2013) Emissions of $\mathrm{CH}_{4}, \mathrm{~N}_{2} \mathrm{O}, \mathrm{NH}_{3}$ and odorants from pig slurry during winter and summer storage. Nutrient Cycling in Agroecosystems, 95, 103-113.

Petersen SO, Højberg O, Poulsen M, Schwab C, Eriksen J (2014) Methanogenic community changes, and emissions of methane and other gases, during storage of acidified and untreated pig slurry. Journal of Applied Microbiology.

Philippe FX, Laitat M, Canart B, Vandenheede M, Nicks B (2007a) Gaseous emissions during the fattening of pigs kept either on fully slatted floors or on straw flow. Animal, 1, 1515-23.

Philippe FX, Laitat M, Canart B, Vandenheede M, Nicks B (2007b) Comparison of ammonia and greenhouse gas emissions during the fattening of pigs, kept either on fully slatted floor or on deep litter. Livestock Science, 111, 144-152.

Philippe FX, Laitat M, Wavreille J, Bartiaux-Thill N, Nicks B, Cabaraux JF (2011) Ammonia and greenhouse gas emission from group-housed gestating sows depends on floor type. Agriculture, Ecosystems \& Environment, 140, 498-505.

Philippe FX, Laitat M, Nicks B, Cabaraux JF (2012) Ammonia and greenhouse gas emissions during the fattening of pigs kept on two types of straw floor. Agriculture, Ecosystems \& Environment, $150,45-53$.

Philippe FX, Laitat M, Wavreille J, Nicks B, Cabaraux JF (2013) Influence of permanent use of feeding stalls as living area on ammonia and greenhouse gas emissions for group-housed gestating sows kept on straw deep-litter. Livestock Science, 155, 397-406.

Pinheiro J, Bates D, DebRoy S, Sarkar D (2014) nlme: Linear and Nonlinear Mixed Effects Models. R package version 3.1-117. http://CRAN.R-project.org/package $=n l m e$.

Portejoie S, Martinez J, Guiziou F, Coste CM (2003) Effect of covering pig slurry stores on the ammonia emission processes. Bioresource Technology, 87, 199-207.

Portejoie S, Dourmad JY, Martinez J, Lebreton Y (2004) Effect of lowering dietary crude protein on nitrogen excretion, manure composition and ammonia emission from fattening pigs. Livestock Production Science, 91, 45-55. 
Van Ransbeeck N, Van Langenhove H, Demeyer P (2013) Indoor concentrations and emissions factors of particulate matter, ammonia and greenhouse gases for pig fattening facilities. Biosystems Engineering, 116, 518-528.

Rochette P, van Bochove E, Pre'vost D, Angers DA, Co^te' D, Bertrand N (2000) Soil Carbon and Nitrogen Dynamics Following Application of Pig Slurry for the 19th Consecutive Year. Soil Science Society of America Journal, 64, 1396.

Rodhe L, Karlsson S (2002) Ammonia Emissions from Broiler Manure - Influence of Storage and Spreading Method. Biosystems Engineering, 82, 455-462.

Rodhe L, Pell M, Yamulki S (2006) Nitrous oxide, methane and ammonia emissions following slurry spreading on grassland. Soil Use and Management, 22, 229-237.

Rodhe LKK, Abubaker J, Ascue J, Pell M, Nordberg Å (2012) Greenhouse gas emissions from pig slurry during storage and after field application in northern European conditions. Biosystems Engineering, 113, 379-394.

Sagoo E, Williams JR, Chambers BJ, Boyles LO, Matthews R, Chadwick DR (2007) Integrated management practices to minimise losses and maximise the crop nitrogen value of broiler litter. Biosystems Engineering, 97, 512-519.

Saha CK, Ammon C, Berg W et al. (2014) Seasonal and diel variations of ammonia and methane emissions from a naturally ventilated dairy building and the associated factors influencing emissions. The Science of the Total Environment, 468-469, 53-62.

Schouten S, van Groenigen JW, Oenema O, Cayuela ML (2012) Bioenergy from cattle manure? Implications of anaerobic digestion and subsequent pyrolysis for carbon and nitrogen dynamics in soil. GCB Bioenergy, 4, 751-760.

Schrade S, Zeyer K, Gygax L, Emmenegger L, Hartung E, Keck M (2012) Ammonia emissions and emission factors of naturally ventilated dairy housing with solid floors and an outdoor exercise area in Switzerland. Atmospheric Environment, 47, 183-194.

Shah GM, Groot JCJ, Oenema O, Lantinga EA (2012) Covered storage reduces losses and improves crop utilisation of nitrogen from solid cattle manure. Nutrient Cycling in Agroecosystems, 94, 299-312.

Sistani KR, Warren JG, Lovanh N, Higgins S, Shearer S (2010) Greenhouse Gas Emissions from Swine Effluent Applied to Soil by Different Methods. Soil Science Society of America Journal, 74, 429.

Smith KA, Jackson DR, Misselbrook TH, Pain BF, Johnson RA (2000) Reduction of Ammonia Emission by Slurry Application Techniques. Journal of Agricultural Engineering Research, 77, 277-287.

Smith K, Cumby T, Lapworth J, Misselbrook T, Williams A (2007) Natural crusting of slurry storage as an abatement measure for ammonia emissions on dairy farms. Biosystems Engineering, 97, 464-471.

Smits MCJ, Valk H, Elzing A, Keen A (1995) Effect of protein nutrition on ammonia emission from a cubicle house for dairy cattle. Livestock Production Science, 44, 147-156.

Sommer SG (1997) Ammonia volatilization from farm tanks containing anaerobically digested animal slurry. Atmospheric Environment, 31, 863-868.

Sommer S. (2001) Effect of composting on nutrient loss and nitrogen availability of cattle deep litter. European Journal of Agronomy, 14, 123-133.

Sommer SG, Dahl P (1999) Nutrient and carbon balance during the composting of deep Litter. Journal of Agricultural Engineering Research, 74, 145-153.

Sommer S, Hutchings N (2001) Ammonia emission from field applied manure and its reductioninvited paper. European Journal of Agronomy, 15, 1-15. 


\section{Chapter 4}

Sommer S, Olesen J (1991) Effects of dry matter content and temperature on ammonia loss from surface-applied cattle slurry. Journal of Environmental Quality, 20, 679-683.

Sommer SG, Sherlock RR, Khan RZ (1996) Nitrous oxide and methane emissions from pig slurry amended soils. Soil Biology and Biochemistry, 28, 1541-1544.

Sommer S, Petersen SO, Segaard HT (2000) Greenhouse gas emission from stored livestock slurry. Journal of Environment Quality, 29, 744-751.

Sommer SG, Petersen SO, Møller HB (2004) Algorithms for calculating methane and nitrous oxide emissions from manure management. Nutrient Cycling in Agroecosystems, 69, 143-154.

Sommer SG, Petersen SO, Sørensen P, Poulsen HD, Møller HB (2007) Methane and carbon dioxide emissions and nitrogen turnover during liquid manure storage. Nutrient Cycling in Agroecosystems, 78, 27-36.

Sommer SG, Olesen JE, Petersen SO, Weisbjerg MR, Valli L, Rohde L, Béline F (2009) Regionspecific assessment of greenhouse gas mitigation with different manure management strategies in four agroecological zones. Global Change Biology, 15, 2825-2837.

Steinfeld H, Gerber P, Wassenaar T, Castel V, Roslaes M, De Haan C (2006) Livestock's long shadow. Environmental Issues and Options. FAO report, Rome, Italy.

Van der Stelt B, van Vliet PCJ, Reijs JW, Temminghoff EJM, van Riemsdijk WH (2008) Effects of dietary protein and energy levels on cow manure excretion and ammonia volatilization. Journal of Dairy Science, 91, 4811-21.

Sutton MA, Erisman JW, Dentener F, Möller D (2008) Ammonia in the environment: from ancient times to the present. Environmental Pollution, 156, 583-604.

Swierstra D, Smits M, Kroodsma W (1995) Ammonia emission from cubicle houses for cattle with slatted and solid floors. Journal of Agricultural Engineering Research, 62, 127-132.

Szanto GL, Hamelers HVM, Rulkens WH, Veeken AHM (2007) $\mathrm{NH}_{3}, \mathrm{~N}_{2} \mathrm{O}$ and $\mathrm{CH}_{4}$ emissions during passively aerated composting of straw-rich pig manure. Bioresource Technology, 98, 2659-70.

Thomsen IK, Pedersen AR, Nyord T, Petersen SO (2010) Effects of slurry pre-treatment and application technique on short-term $\mathrm{N}_{2} \mathrm{O}$ emissions as determined by a new non-linear approach. Agriculture, Ecosystems \& Environment, 136, 227-235.

Vallejo A, García-Torres L, Díez JA, Arce A, López-Fernández S (2005) Comparison of N losses $\left(\mathrm{NO}_{3}^{-}, \mathrm{N}_{2} \mathrm{O}, \mathrm{NO}\right)$ from surface applied, injected or amended (DCD) pig slurry of an irrigated soil in a Mediterranean climate. Plant and Soil, 272, 313-325.

Vallejo A, Skiba U, Garciatorres L, Arce A, Lopezfernandez S, Sanchezmartin L (2006) Nitrogen oxides emission from soils bearing a potato crop as influenced by fertilization with treated pig slurries and composts. Soil Biology and Biochemistry, 38, 2782-2793.

VanderZaag A, Gordon R (2010) Permeable synthetic covers for controlling emissions from liquid dairy manure. Applied Engineering in Agriculture, 26, 287-298.

VanderZaag AC, Gordon RJ, Jamieson RC, Burton DL, Stratton GW (2009) Gas emissions from straw covered liquid dairy manure during summer storage and autumn agitation. Transactions of the $A S A B E, 52,599-608$.

Velthof GL, Mosquera J (2011) The impact of slurry application technique on nitrous oxide emission from agricultural soils. Agriculture, Ecosystems \& Environment, 140, 298-308.

Velthof G, Kuikman P, Oenema O (2003) Nitrous oxide emission from animal manures applied to soil under controlled conditions. Biology and Fertility of Soils, 37, 221-230.

Velthof GL, Nelemans J a, Oenema O, Kuikman PJ (2005) Gaseous nitrogen and carbon losses from pig manure derived from different diets. Journal of Environmental Quality, 34, 698-706. 
Wang K, Huang D, Ying H, Luo H (2014) Effects of acidification during storage on emissions of methane, ammonia, and hydrogen sulfide from digested pig slurry. Biosystems Engineering, 122, 23-30.

Webb J, Chadwick D, Ellis S (2004) Emissions of ammonia and nitrous oxide following incorporation into the soil of farmyard manures stored at different densities. Nutrient Cycling in Agroecosystems, 70, 67-76.

Webb J, Pain B, Bittman S, Morgan J (2010) The impacts of manure application methods on emissions of ammonia, nitrous oxide and on crop response-A review. Agriculture, Ecosystems \& Environment, 137, 39-46.

Webb J, Thorman RE, Fernanda-Aller M, Jackson DR (2014) Emission factors for ammonia and nitrous oxide emissions following immediate manure incorporation on two contrasting soil types. Atmospheric Environment, 82, 280-287.

Weslien P, Klemedtsson L, Svensson L, Galle B, Kasimir-Klemedtsson Å, Gustafsson A (2006) Nitrogen losses following application of pig slurry to arable land. Soil Use and Management, 14, 200-208.

Wu W, Zhang G, Kai P (2012) Ammonia and methane emissions from two naturally ventilated dairy cattle buildings and the influence of climatic factors on ammonia emissions. Atmospheric Environment, 61, 232-243.

Wulf S, Maeting M, Clemens J (2002a) Application technique and slurry co-fermentation effects on ammonia, nitrous oxide, and methane emissions after spreading: I. Ammonia volatilization. Journal of Environment Quality, 31, 1789-1794.

Wulf S, Maeting M, Clemens J (2002b) Application technique and slurry co-fermentation effects on ammonia, nitrous oxide, and methane emissions after spreading: II. Greenhouse Gas Emissions. Journal of Environment Quality, 31, 1795-1801. 



\section{CHAPTER 5}

\section{Nutrient recovery and emissions of ammonia, nitrous oxide and methane from animal manure in Europe: effects of manure treatment technologies}




\title{
Chapter 5
}

\begin{abstract}
Animal manure contributes considerably to ammonia $\left(\mathrm{NH}_{3}\right)$ and greenhouse gas (GHG) emissions in Europe. Various treatment technologies have been implemented to reduce emissions and to facilitate its use as fertilizer, but a systematic analysis of these technologies has not been carried out yet. Here, we present an integrated assessment of manure treatment effects on $\mathrm{NH}_{3}$, nitrous oxide $\left(\mathrm{N}_{2} \mathrm{O}\right)$ and methane $\left(\mathrm{CH}_{4}\right)$ emissions from manure management chains in EU-27 in 2010, using the model MITERRA-Europe. Whole-chain effects of implementing twelve treatment technologies on emissions and nutrient recovery were further explored through scenario analyses; the level of implementation corresponded to levels currently achieved by forerunner countries. Manure treatment decreased national GHG emissions from manures by $0-17 \%$ in 2010 , with the largest contribution from anaerobic digestion; the effects on $\mathrm{NH}_{3}$ emissions were small. Scenario analyses indicate that increased implementation of acidification, thermal drying, incineration and pyrolysis may decrease both $\mathrm{NH}_{3}(9-11 \%)$ and GHG (11-18\%) emissions; nitrification-denitrification treatment decreased $\mathrm{NH}_{3}$ emissions, but increased GHG emissions. The nitrogen recovery (\% of nitrogen excreted in housings that is applied to land) would increase from a mean of 57\% (in 2010) to $61 \%$ by acidification, but would decrease to $48 \%$ by incineration. Promoting optimized manure treatment technologies can greatly contribute to achieving $\mathrm{NH}_{3}$ and $\mathrm{GHG}$ emission targets of EU regulations.
\end{abstract}




\subsection{Introduction}

Animal manure is a main source of plant-available nutrients, but also a major emission source of ammonia $\left(\mathrm{NH}_{3}\right)$ and greenhouse gases $(\mathrm{GHG})$ - nitrous oxide $\left(\mathrm{N}_{2} \mathrm{O}\right)$ and methane $\left(\mathrm{CH}_{4}\right)$. Manure from animal production is responsible for about $40 \%$ of the global anthropogenic $\mathrm{NH}_{3}$ and $\mathrm{N}_{2} \mathrm{O}$ emissions (Galloway et al., 2004; Oenema et al., 2005). Approximately 35-40\% of the global anthropogenic $\mathrm{CH}_{4}$ emissions are associated with the livestock sector (about $6 \%$ from manure management and the remaining from enteric fermentation) (Steinfeld et al., 2006). In Europe, animal manures contribute about $65 \%$ to the total anthropogenic $\mathrm{NH}_{3}$ emissions, $40 \%$ to $\mathrm{N}_{2} \mathrm{O}$ emissions and $10 \%$ to $\mathrm{CH}_{4}$ emissions (Oenema et al., 2007, 2014; EEA, 2014a, 2014b). Farm animals excreted 9.7 Tg N and 1.7 Tg P in the European Union (EU) in 2010, equivalent to about $95 \%$ and $160 \%$ of the total use of mineral $\mathrm{N}$ and $\mathrm{P}$ fertilizers (Eurostat; Hou et al., 2016).

Emissions of $\mathrm{NH}_{3}, \mathrm{~N}_{2} \mathrm{O}$ and $\mathrm{CH}_{4}$ may occur simultaneously from different sources of manure management systems that typically include animal houses, manure storages, manure application to land and droppings from grazing animals in pastures. Introducing a management measure may have interactive effects on emissions of these gases from a specific source; it may also influence emissions downstream in the system and hence the nutrient recovery from the manure (Sommer et al., 2009; Velthof et al., 2009; Hou et al., 2015). The whole manure management chain needs to be considered therefore, when assessing effects of measures on gaseous emissions and nutrient recycling and recovery.

Manure treatment technologies have been increasingly applied in practice in Europe during the last few decades, driven by the specialization/intensification of animal production and the tightened enforcement of EU environmental policies (Oenema et al., 2011). Manure treatment creates management opportunities to better use the nutrients and organic matter in manure. Treatment may induce changes in physical, chemical and/or biological properties of the manure and hence influence emissions of $\mathrm{NH}_{3}$ and $\mathrm{GHG}$ throughout the whole management chain. An inventory reported that $7.8 \%$ of manure production in the EU was processed in 2010, but with large variations among countries (range 0-35\%) (Foged et al., 2011). While the growth in implementation of manure treatment is in general lauded as an environmental success (Sommer et al., 2013), there is a need for systematic environmental assessment of manure treatment, also to provide guidance for the further development of proper manure management strategies. 


\section{Chapter 5}

Only few studies have assessed losses of $\mathrm{N}$ and $\mathrm{GHG}$ emissions from the animal production systems at country and EU scales (Oenema et al., 2009; Lesschen et al., 2011; Weiss \& Leip, 2012). Manure treatment techniques are usually not considered in these large-scale studies, and as a consequence their environmental impacts have not been systematically addressed. Yet, a large number of laboratory and pilot experiments have been carried out to analyze $\mathrm{NH}_{3}$ and GHG emissions from processed manures, most of them typically focused on a specific gas/substance or emission source (Petersen et al., 2007; Thangarajan et al., 2013; Hou et al., 2015). Whole-farm (or life cycle) assessments were mostly conducted on the basis of specific farm-scale characteristics. Manure management systems and the implementation of $\mathrm{NH}_{3}$ abatement measures (e.g. low-emission stables, storage systems and application methods) vary greatly among farms and countries (UNFCCC; Asman et al., 2011). These farm and country-specific contexts may also influence the performance of manure treatment technologies. There is as yet little information about the potential effects of manure treatment technologies in the EU. In particular, there is insufficient understanding of possible synergistic and antagonistic effects of manure treatment on emissions of $\mathrm{NH}_{3}, \mathrm{~N}_{2} \mathrm{O}$ and $\mathrm{CH}_{4}$ and on nutrient recovery.

The objectives of this study are to assess the contribution of manure treatment techniques to emissions of $\mathrm{NH}_{3}, \mathrm{~N}_{2} \mathrm{O}$ and $\mathrm{CH}_{4}$ at national level for the EU-27 in 2010, using the improved model MITERRA-Europe (Velthof et al., 2009; Lesschen et al., 2011). Further, we explored the whole-chain impact potentials of treatment technologies on gaseous emissions and nutrient recovery through scenario analyses. We also executed an uncertainty analysis.

\subsection{Materials and methods}

System boundary. The whole chain from 'animal excretion, in-house and outdoor manure storage, manure treatment, application of manure to land, and deposition of urine and faeces in pastures during grazing' in the EU-27 was considered in this study. The system boundary, the main flows of nutrients embodied in animal manures and the possible manure treatment techniques are illustrated in Figure 5-1, defined according to literature (Velthof et al., 2009; Foged et al., 2011; Lesschen et al., 2011). Faeces and urine are deposited by grazing animals in pastures and produced by housed animals in housings. Excreta from housings are applied to agricultural land after a period of storage in either liquid or solid form, or in some cases are treated by certain technologies. The main treatment technologies currently applied in Europe are solid-liquid separation, anaerobic digestion, acidification, biological aerobic $\mathrm{N}$ removal 
(i.e. nitrification-denitrification), composting, (thermal or bio-) drying and incineration (Foged et al., 2011). The use of treatment technologies depends on manure types (e.g. liquids, slurry and solid manure). Treated manure products are typically returned to soil, as fertilizers or soil amendments (Foged et al., 2011; Sommer et al., 2013). In addition, several $\mathrm{NH}_{3}$ mitigation measures have been adopted alongside the manure management chain, but depending on country (Oenema et al., 2009).

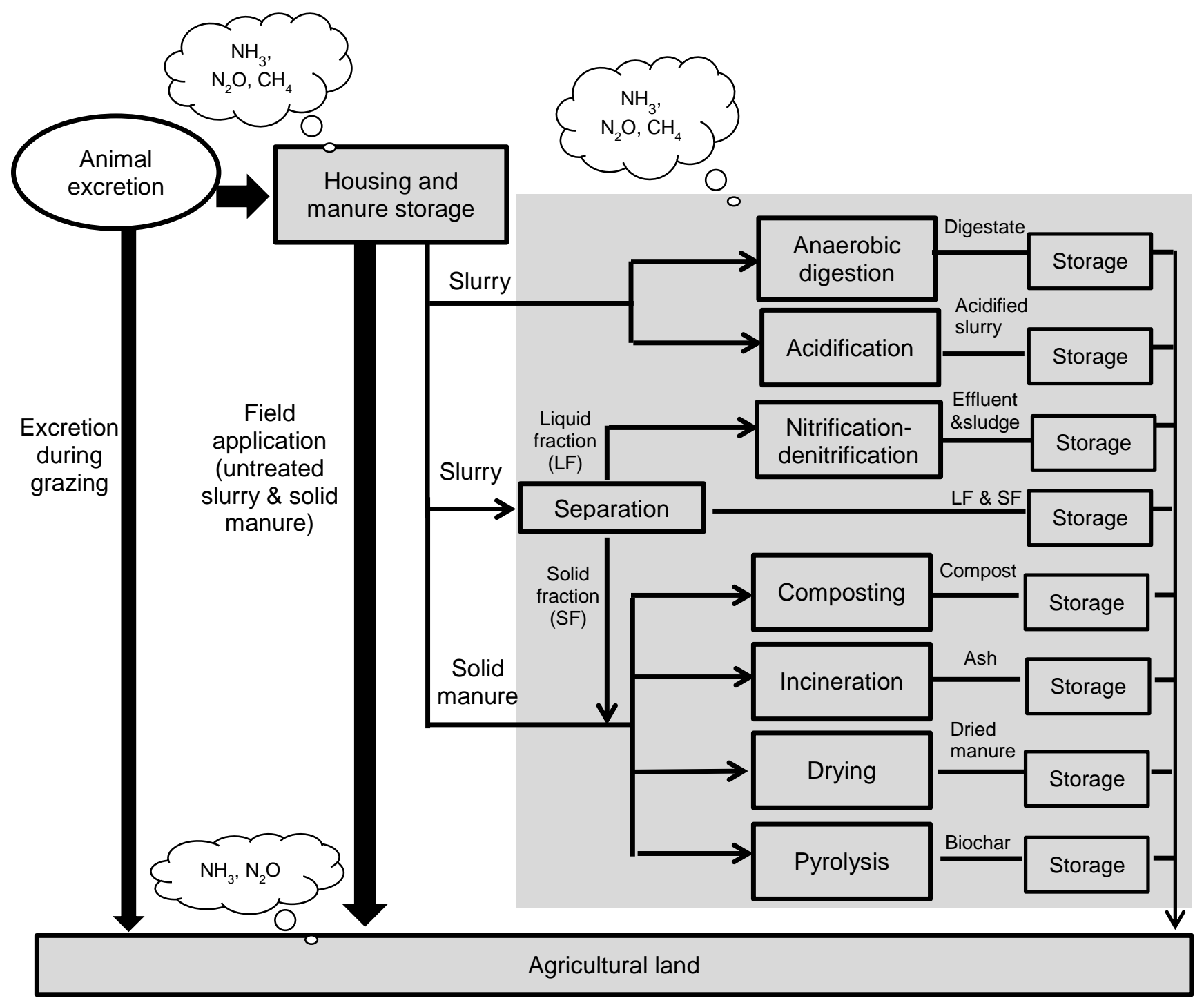

Figure 5-1. Schematic representation of the manure management chain with possible manure treatment technologies (highlighted in grey) discussed in this study. The arrows indicate the main flows of manure products. The clouds show emission sources of ammonia $\left(\mathrm{NH}_{3}\right)$, nitrous oxide $\left(\mathrm{N}_{2} \mathrm{O}\right)$ and methane $\left(\mathrm{CH}_{4}\right)$ from animal manure. 


\section{Chapter 5}

Emission sources. Emissions of $\mathrm{NH}_{3}, \mathrm{~N}_{2} \mathrm{O}$ and $\mathrm{CH}_{4}$ from the manure management chain of the EU-27 were quantified at national scales in 2010. Animal categories include dairy cows, other cattle, pigs, poultry, sheep and goats, which are the main categories in Europe (Lesschen et al., 2011). Emission sources include emissions of $\mathrm{NH}_{3}, \mathrm{~N}_{2} \mathrm{O}$ and $\mathrm{CH}_{4}$ from animal manure in animal housing, manure storage and treatment systems, and emissions of $\mathrm{NH}_{3}$ and $\mathrm{N}_{2} \mathrm{O}$ from manure applied to land and deposited in pastures (Figure 5-1). Indirect $\mathrm{N}_{2} \mathrm{O}$ emissions were excluded. As our study focuses on manure management, enteric $\mathrm{CH}_{4}$ emissions were not considered.

MITERRA-Europe and data sources. For calculations, the model MITERRA-Europe was further developed and used. MITERRA-Europe is an integrated environmental assessment model which calculates the $\mathrm{N}$ and $\mathrm{P}$ losses, and GHG emissions on a deterministic and annual basis, using statistical data of agriculture at EU country and regional levels (Velthof et al., 2009; Lesschen et al., 2011). Country specific $\mathrm{NH}_{3}$ emission factors (EFs) are based on information from the GAINS model, and quantification of $\mathrm{N}_{2} \mathrm{O}$ and $\mathrm{CH}_{4}$ emissions are based on the IPCC guidelines (Klimont \& Brink, 2004; Asman et al., 2011).

The $\mathrm{N}$ and $\mathrm{P}$ excretion for each animal category and country was quantified on the basis of a three-year average (2009-2011), using the nutrient balance of feed intake and animal production (Hou et al., 2016). Data about manure management systems (i.e. animal grazing, daily spreading, liquid and solid based systems) were sourced from the national GHG inventory reports (NIRs) to UNFCCC (UNFCCC, 2016). Data about the degree of implementation of $\mathrm{NH}_{3}$ mitigation measures and their abatement efficiencies were obtained from GAINS (Klimont \& Brink, 2004; Asman et al., 2011), supplemented with information from $\mathrm{NH}_{3}$ mitigation guidance (UNECE) and review articles (e.g. Melse \& Timmerman, 2009; Bittman et al., 2014; Hou et al., 2015; Pardo et al., 2015; Van der Heyden et al., 2015). The IPCC default $\mathrm{N}_{2} \mathrm{O}-\mathrm{N}$ EFs were adopted to quantify emissions of $\mathrm{N}_{2} \mathrm{O}$ from manure management systems, manure application and deposition (IPCC, 2006). For calculating $\mathrm{CH}_{4}$ emissions, country-specific methane conversion factors (MCFs) for each animal category and manure management system were obtained from NIRs to UNFCCC, considering the allocation of manure management systems among climate zones. Data on nutrient excretion (Table S1) and emission factors (Table S2) are shown in supporting information (SI). 
Emissions of $\mathrm{GHG}$, including $\mathrm{N}_{2} \mathrm{O}$ and $\mathrm{CH}_{4}$, were converted to $\mathrm{CO}_{2}$-equivalent $\left(\mathrm{CO}_{2}\right.$-eq), considering the global warming potential of 25 and 298 times of that of $\mathrm{CO}_{2}$ for $\mathrm{CH}_{4}$ and $\mathrm{N}_{2} \mathrm{O}$ emissions, respectively.

Emissions from manure treatment. A 'manure treatment' module was developed to assess environmental effects of the main treatment technologies in the manure management chain (Figure 5-1). Information on the use of treatment techniques in each country in 2010 was derived from an inventory report on manure treatment activities and NIRs to UNFCCC (UNFCCC, 2016; Foged et al., 2011). Parameters related to emissions $\left(\mathrm{NH}_{3}, \mathrm{~N}_{2} \mathrm{O}\right.$ and $\left.\mathrm{CH}_{4}\right)$ from manure treatment, storage and field application (treated manure), and nutrient recovery are shown in Table S3. Specific characteristics of referenced technologies are follows:

Solid-liquid separation. Three groups of mechanical separator were included: i) screw and filter pressing, ii) non-pressurized filtration and iii) centrifugation and sedimentation. Their separation efficiencies (i.e. the mass of a nutrient element in separated solid fraction, expressed as $\%$ of the mass of this element in raw slurry) varied from $10-33 \%$ for $\mathrm{N}$ and 15 $69 \%$ for $\mathrm{P}$, which were higher when flocculates and multivalent cations (coagulationflocculation) were added (Table S3).

Slurry acidification. Acidification involves the addition of concentrated acid (e.g. sulfuric acid) to the slurry in house under slatted floors each day, to lower the $\mathrm{pH}$ to 5.5. A fraction of the acidified slurry is then transferred to an outside storage tank without further treatment (Kai et al., 2008; Petersen et al., 2016). The average $\mathrm{NH}_{3}$ abatement efficiency was $65 \%$ in housing, $83 \%$ in outdoor storage and $40 \%$ during application; a reduction of $87 \%$ for $\mathrm{CH}_{4}$ emissions from housing and storage systems was found (Kai et al., 2008; Hou et al., 2015; Petersen et al., 2016).

Anaerobic digestion. Anaerobic digestion of animal slurry in EU is dominantly operated under mesophilic conditions (Foged et al., 2011). Biogas production from slurry was quantified as function of volatile solid inputs, the yield of $\mathrm{CH}_{4}$ and the biogas composition (Hamelin et al., 2011). Biogas is considered to be composed of $55-65 \% \mathrm{CH}_{4}$ and $35-45 \% \mathrm{CO}_{2}$, depending on country. Leakage is assumed as $1 \%$ of the gross biogas production (Miranda et $a l ., 2015)$. Liquid and solid fractions were produced from digested slurry, when mechanical separators were used as post treatment. 


\section{Chapter 5}

Nitrification-denitrification treatment. This technology includes a separation unit (pretreatment), a nitrification-denitrification process (with liquid fractions as input) and a settlement/separation unit (post-treatment). The resulting sludge and liquid effluent (posttreatment), and solid fractions (pre-treatment) are stored before application. Emission factors during treatment and storage were derived from studies conducted in Belgium, France and the Netherlands, where this technique has been applied in practice (Table S3) (Willers et al., 1996; Béline \& Martinez, 2002; Loyon et al., 2007; Bernet \& Béline, 2009; Melse \& Timmerman, 2009).

Composting. Manure sources used for composting consist of solid manure and solid fractions separated from slurry (Foged et al., 2011). Emissions of $\mathrm{NH}_{3}$ from composting were considered to be $52 \%$ higher on average than those from conventional storage, whereas emissions of $\mathrm{CH}_{4}(71 \%)$ and $\mathrm{N}_{2} \mathrm{O}(49 \%)$ were lower on average; these percentages were derived from a meta-analysis study (Pardo et al., 2015).

Thermal drying. Poultry manure and separated solid fractions are dried at temperate of 80$150^{\circ} \mathrm{C}$, which is commonly followed by pelletizing as post treatment (Foged et al., 2011). Gaseous emissions from the dryer must be recovered to avoid $\mathrm{NH}_{3}$ emissions, and air scrubber was assumed to be installed with average $\mathrm{NH}_{3}$ abatement efficiency of $85 \%$ (Foged et al., 2011; Ghaly \& Alhattab, 2013). Methane emissions were assumed to be negligible under aerobic conductions.

Bio-drying. This technique is used to treat poultry manure and solid fractions separated from slurry to lower moisture content (by 40-60\%) and to facilitate transport. This technique has not been widely used in EU (Foged et al., 2011). Emissions of $\mathrm{NH}_{3}$ are assumed to be increased (by 121\%) relative to static piling due to the forced aeration (Pardo et al., 2015). Changes in $\mathrm{N}_{2} \mathrm{O}$ and $\mathrm{CH}_{4}$ emissions were not always consistent, therefore EFs were assumed the same as that for static piling (Pardo et al., 2015).

Incineration. Industrial-scale incineration of poultry manure exists in several EU countries (e.g. the Netherlands and UK), with the net energy surplus being used for electricity generation (Foged et al., 2011; Billen et al., 2015). The gases released from this process (with gas cleaning installation) mainly consist of $\mathrm{CO}_{2}$ and $\mathrm{N}_{2}$, while other emissions $\left(\mathrm{NH}_{3}, \mathrm{~N}_{2} \mathrm{O}\right.$, NOx and $\mathrm{CH}_{4}$ ) are minor or negligible (Billen et al., 2015). Ash residues contain all $\mathrm{P}$ input from feedstocks and no or only a limited fraction (less than 2\%) of the $\mathrm{C}$ and $\mathrm{N}$ input (Brassard et al., 2014; Christel et al., 2014; Billen et al., 2015; Fernandez-Lopez et al., 2015). 
Emissions from application of treated manure. Emissions of $\mathrm{NH}_{3}$ and $\mathrm{N}_{2} \mathrm{O}$ following the application of treated manure were estimated from their $\mathrm{N}$ contents and the specific EFs (Table S2 and Table S3). Emission factors were basically obtained from review articles (e.g. meta-analysis), and also from a number of experimental studies.

Defining scenarios. Effects of treatment technologies on emissions of $\mathrm{NH}_{3}, \mathrm{~N}_{2} \mathrm{O}$ and $\mathrm{CH}_{4}$ from manure, and the $\mathrm{N}$ and $\mathrm{P}$ flows in the manure management chain of the EU-27 were further examined through scenario analyses. The assessment focuses on exploring the wholechain effects and the interactions between gas emissions when certain treatment technologies are implemented. Scenarios are summarized in Table 5-1. Twelve scenarios (S1-12) were compared with the reference, a situation without manure treatment. For all scenarios, we assumed that an equivalent of $20 \%$ of total manure $(\mathrm{N})$ removed from animal houses in each country was processed. For all technologies, the same amounts of treated manure are considered, allowing technology comparison. The assumption of $20 \%$ implementation corresponded more or less to the upper bound of the degree of implementation of specific treatment in EU countries at present. For example, $11 \%$ of total slurry produced was acidified in Denmark in 2010 (Foged et al., 2011), and nearly 20\% in 2015. In Italy, 24\% of total slurry was treated by solid-liquid separation (Foged et al., 2011). Anaerobic digestion was applied to $13-24 \%$ of pig and cattle slurry in Germany, 20-35\% in Italy, and 30\% of pig slurry in Cyprus (UNFCCC). Nearly one third of chicken manures in the Netherlands was incinerated in 2010, and $15 \%$ in UK (Foged et al., 2011; Billen et al., 2015).

Scenarios include increased implementation of single techniques to treat raw slurry (S1-5) and solid manure (S6-9), and also advanced combination of technologies (S10-12). For scenarios with raw slurry as feedstock (S1-5, 10-12), treatment technologies were considered to be applied to slurry removed from animal houses; the amount of slurry that is treated in each scenario equals to $20 \%$ of total manure (i.e. the sum of slurry and solid manure) removed from houses, in terms of $\mathrm{N}$. There is an exception for acidification $(\mathrm{S} 4, \mathrm{~S} 10)$ that is applied to slurry in the houses (i.e. before removal). For scenarios with solid manure as feedstock, technologies were applied to solid manure removed from houses; the amount equals to $20 \%$ of total (slurry and solid) manure removed. The total amounts of solid manure (or slurry) that are assumed to be treated may be less than $20 \%$ of total manure removed from houses in few countries where manure was produced dominantly as slurry (solid manure).

Although studies about pyrolysis of solid manure have been conducted, this technique has not 


\section{Chapter 5}

yet been commercially implemented in Europe (Foged et al., 2011). In scenario (S9), slow pyrolysis of manure at temperature of $600^{\circ} \mathrm{C}$ was considered with the purpose of producing a stabilized biochar. The mass (C, N and P) balance in pyrolysis is detailed in SI (Table S3). Three treatment systems with combinations of technologies were designed (S10-12) based on literature (Gioelli et al., 2016; Regueiro et al., 2016). In scenario S10, we assumed that slurries that are acidified in houses (as S4) are separated by decanter centrifuge before outdoor storage. In scenario S11, slurries removed from houses are separated (as S2), and followed by acidifying the liquid fractions and by pyrolysis of the solid fractions. In scenario S12, we assumed that all digested slurries from anaerobic digestion (as S3) are acidified and immediately separated (centrifuge).

Uncertainty analysis. Uncertainty analysis was carried out to achieve insight in how variation in the key parameters in the model affected the results, using a Monte Carlo (MC) based method (Zhu et al., 2015). Six groups of parameter were included in this analysis: i) animal numbers, ii) parameters related to nutrient excretion, iii) parameters used to quantify emissions from housing and manure storages (e.g. emission factors), iv) parameters related to manure treatment, v) parameters related to manure application, and vi) manure treatment activity data. Parameter uncertainty is shown in Table S4. The model output uncertainty in response to uncertainty of the parameters was quantified for the year 2010, the reference (without manure treatment) and the scenarios (1000 MC runs each). The difference in emissions between the reference and each treatment scenario was statistically analyzed by comparing the MC simulating outputs, using Tukey HSD test. In addition, the uncertainty contribution of six parameter groups to the overall uncertainty was analyzed for the year 2010 . 
Table 5-1. Description of manure treatment scenarios ${ }^{\mathrm{a}}$

\begin{tabular}{|c|c|c|c|c|}
\hline \multirow[t]{2}{*}{ Scenarios } & \multirow[t]{2}{*}{ Origin of feedstock } & \multirow[t]{2}{*}{ Brief description of treatment systems } & \multicolumn{2}{|c|}{ Manure products } \\
\hline & & & Liquid form & Solid form \\
\hline S1: Screw press & Slurry (cattle, pigs) & Screw press; LF, SF are not treated further & LF (liquid fraction) & SF (solid fraction) \\
\hline S2: Decanter centrifuge & Slurry (cattle, pigs) & Decanter centrifuge; LF, SF are not treated further & $\mathrm{LF}$ & SF \\
\hline S3: Anaerobic digestion (AD) & Slurry (cattle, pigs) & Mesophilic digesters & Digestate; LF of digestate & SF of digestate \\
\hline S4: Acidification (Acid) & Slurry (cattle, pigs) & Acidifying slurry in housing and storage & Acidified slurry & - \\
\hline S5: Nitrification-denitrification & Slurry (cattle, pigs) & Nitrification-denitrification ${ }^{\mathrm{b}}$ & Effluents & Sludge; SF \\
\hline S6: Composting & Solid (cattle, pigs, poultry) & Composting & - & Compost \\
\hline S7: Thermal drying & Solid (cattle, pigs, poultry) & Thermal drying, with air scrubbers & - & Dried pellets \\
\hline S8: Incineration & Solid (cattle, pigs, poultry) & Pre-drying and incineration & - & Ash residues \\
\hline S9: Pyrolysis & Solid (cattle, pigs, poultry) & Slow pyrolysis operated at $\sim 600^{\circ} \mathrm{C}$ & - & Biochar \\
\hline S10: Acid-centrifuge & Slurry (cattle, pigs) & Acidification $->$ centrifuge & Acidified LF & Acidified SF \\
\hline S11: Centrifuge-acid, pyrolysis & Slurry (cattle, pigs) & Centrifuge $->$ acidification (LF); pyrolysis (SF) & Acidified LF & Biochar \\
\hline S12: AD-acid-centrifuge & Slurry (cattle, pigs) & Anaerobic digestion $->$ acidification $->$ centrifuge & Acidified digested LF & Acidified digested SF \\
\hline
\end{tabular}

S12: AD-acid-centrifuge

Slurry (cattle, pigs)

Anaerobic digestion $\rightarrow$ acidification $\rightarrow>$ centrifuge

Acidified digested LF

Acidified digested SF

${ }^{a}$ Parameter inputs (e.g. emissions factors) are shown in SI (e.g. Table S3); ${ }^{b}$ Decanter centrifuge is considered as pre-treatment unit. 
Chapter 5

\subsection{Results}

Manure management chain in 2010. Effects of manure treatment on $\mathrm{NH}_{3}$ and GHG emissions were relatively small in 2010 (Figure 5-2). Approximately 6\% of total N excreted by housed animals was treated in EU-27; countries with excretion being treated above this EU average were all in the EU-15 (except Cyprus; Table S1). Manure treatment altered GHG emissions by $-17 \%$ to $1 \%$ at country levels, and on average by $-4 \%$ at EU level. This was mainly caused by anaerobic digestion (Figure 5-2). Germany, Italy, Denmark, Spain, and the Netherlands had the largest absolute GHG abatement due to manure treatment, sharing $89 \%$ of the total abatement in EU-27. In these five countries, anaerobic digestion abated GHG emissions from manure from 1\% (in Spain) to $9 \%$ (in Germany). Acidification abated 5\% of GHG emissions in Denmark, separation 5\% in Italy, and composting nearly 3\% in Spain (Figure 5-2).

Effects of treatment techniques on $\mathrm{NH}_{3}$ emissions were minor in most EU countries (Figure 52). Reduction in $\mathrm{NH}_{3}$ emissions was relatively large in Denmark due to acidification (5\%), in Belgium (4\%) due to nitrification-denitrification treatment, and in Netherlands and UK (2-3\%) due to incineration.

Total $\mathrm{NH}_{3}$ emissions from the manure management chain in EU were $2.5 \mathrm{Tg} \mathrm{N}$ and GHG emissions were $86.9 \mathrm{Tg} \mathrm{CO}$-eq in 2010 (Figure 5-2a). The proportions of $\mathrm{N}$ and $\mathrm{P}$ excreted in housings that were applied to land (corrected for $\mathrm{NH}_{3}$ emissions) were $57 \%$ (a range of 52-68\% among countries; Table S1) and 98\%, respectively (Table 5-2). 

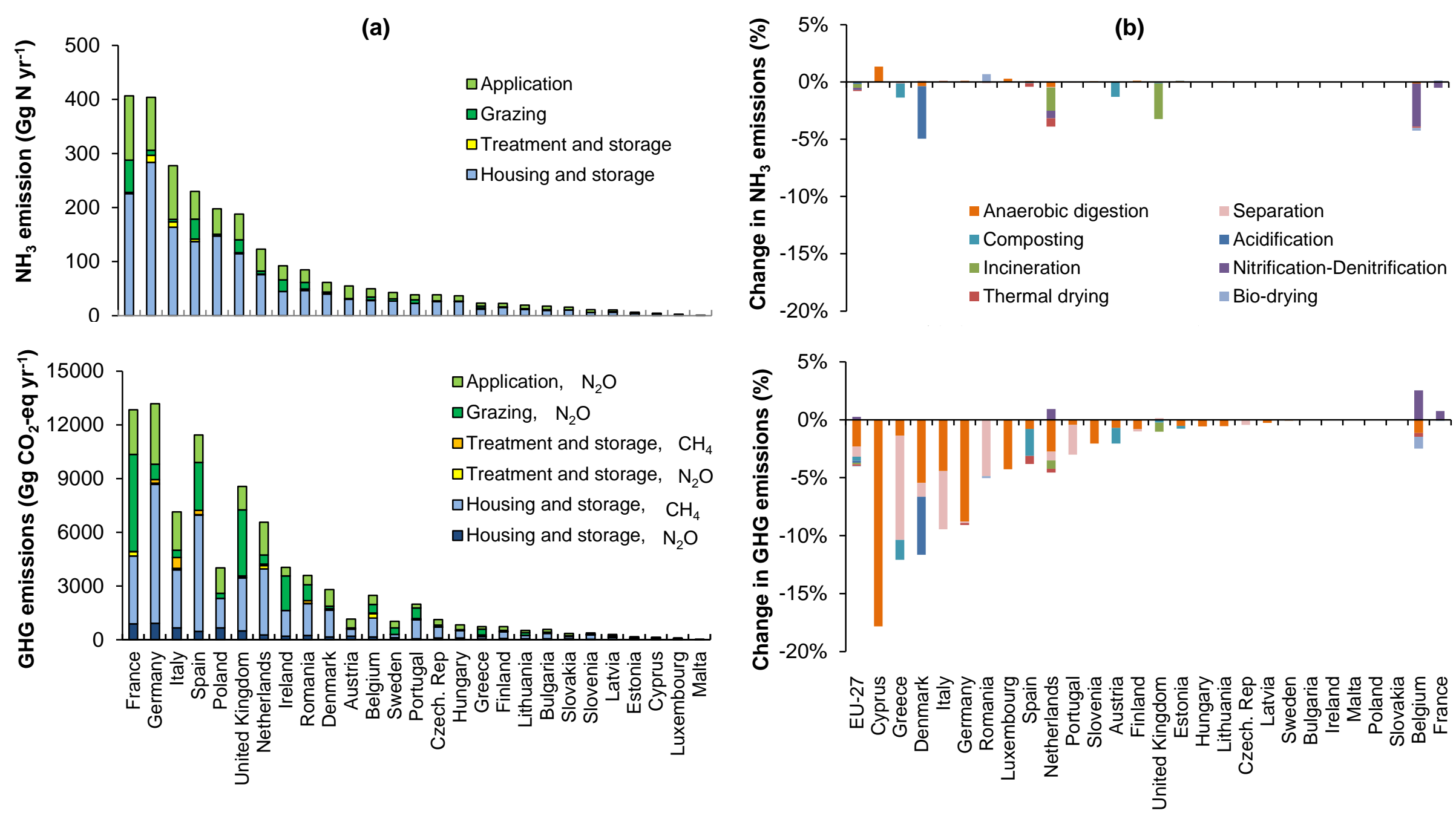

Figure 5-2. Emissions of ammonia $\left(\mathrm{NH}_{3}\right)$, nitrous oxide $\left(\mathrm{N}_{2} \mathrm{O}\right)$ and methane $\left(\mathrm{CH}_{4}\right)$ from manure management chains in countries of EU-27 in 2010 (a), and estimated effects of current manure treatment on $\mathrm{NH}_{3}$ and greenhouse gas (GHG) emissions by comparing situations with and without treatment (b) (positive $=$ increased emission; negative $=$ emission mitigation). 


\section{Chapter 5}

Scenario analyses - $\mathbf{N H}_{3}$ and GHG emissions. Scenarios with increased implementation of manure treatment technologies (20\% of all manure produced in housings) in the EU-27 were compared with the reference (without manure treatment; Figure 5-3).

Increased implementation of slurry separation by screw press (S1) or decanter centrifuge (S2) decreased total GHG emissions by $8 \%$ and $12 \%$, respectively. This reduction is due to decreased $\mathrm{CH}_{4}$ emissions from storage; the greater reduction from decanter centrifuge is related to the larger fraction of storage of separated solid manure. However, total $\mathrm{NH}_{3}$ emissions changed only marginally. Increased adoption of anaerobic digestion (S3) decreased total GHG emissions by $19 \%$ (due to a reduction of $17 \%$ in $\mathrm{CH}_{4}$ emissions), while $\mathrm{NH}_{3}$ emissions were minimally affected. Increased implementation of acidification (S4) decreased both $\mathrm{NH}_{3}$ emissions (mainly from housing and storage) and GHG emissions by $10 \%$ and $18 \%$, respectively. Nitrification-denitrification treatment (S5) decreased both $\mathrm{NH}_{3}$ emissions from storage and treatment systems (by 3\%) and from manure applied to land (5\%). Emissions of $\mathrm{N}_{2} \mathrm{O}$ increased by $28 \%$ due to nitrification-denitrification treatment, though partly off-set by lower $\mathrm{CH}_{4}$ emissions (18\%). This leads to an increase of $6 \%$ in the whole-chain GHG emissions (Figure 5-3).

Composting of solid manure (S6) slightly changed total $\mathrm{NH}_{3}$ emissions; increased emissions during composting were offset by lower emissions following compost application to land. GHG emissions decreased by $7 \%$ relative to the reference. Thermal drying (S7), incineration (S8) and slow pyrolysis (S9) of solid manure decreased both $\mathrm{NH}_{3}$ (9-11\%) and GHG emissions (11-12\%). In these three scenarios (S7-9), decreased GHG emissions are due to reduction in both $\mathrm{CH}_{4}$ emissions from storage systems and $\mathrm{N}_{2} \mathrm{O}$ emissions from field relative to the reference; $\mathrm{NH}_{3}$ emissions decreased during manure storages and application to land (Figure 5-3).

Acidification followed by separation of acidified slurry (S10) decreased $\mathrm{NH}_{3}$ and $\mathrm{GHG}$ emissions nearly similar as implementing acidification alone (S4). Centrifuge separation followed by acidification of liquid fractions and pyrolysis of solid fractions (S11) decreased $\mathrm{NH}_{3}$ emissions by $7 \%$ and GHG emissions by $20 \%$. Anaerobic digestion in combination with acidification and centrifuge (S12) had lower $\mathrm{NH}_{3}$ emissions compared to anaerobic digestion alone (S3), and had similar reduction potential of GHG emissions (Figure 5-3). 

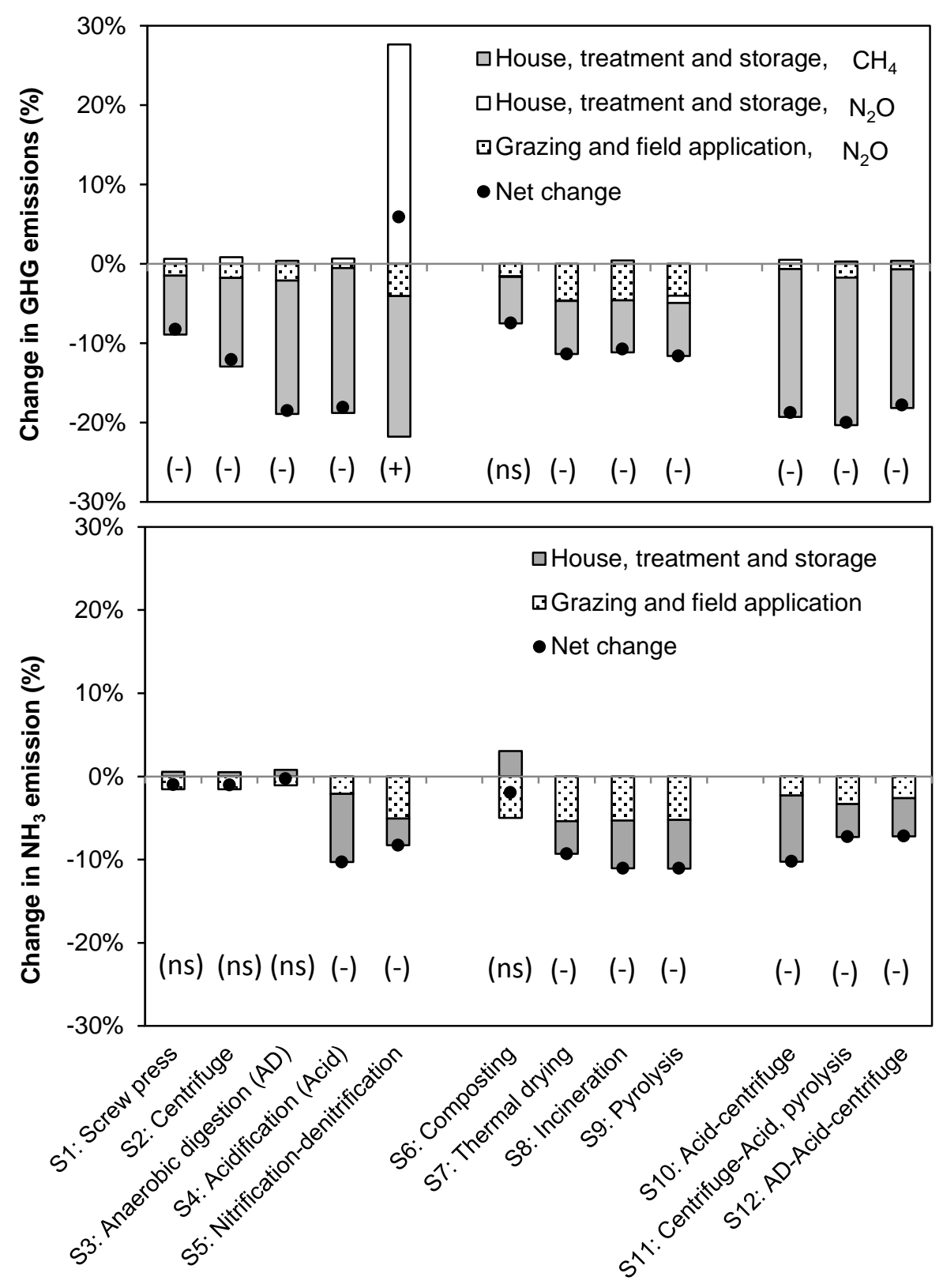

Figure 5-3. Changes in emissions of nitrous oxide $\left(\mathrm{N}_{2} \mathrm{O}\right)$ and methane $\left(\mathrm{CH}_{4}\right)$ (upper panel) and in ammonia $\left(\mathrm{NH}_{3}\right)$ emissions (bottom panel) from the manure management chain following the implementation of manure treatment scenarios, relative to a situation without manure treatment (see text and Table 5-1). For each scenario, it was assumed that $20 \%$ of total manure produced in housings in a country was treated. (-)/(+) indicates significant difference (lower/higher); (ns) indicates nonsignificant difference. 


\section{Chapter 5}

Scenario analyses - nutrient recovery and content. The amount of total $\mathrm{N}$ applied to land, in terms of percentage of total $\mathrm{N}$ excreted in housing in EU-27, increased from $57 \%$ to $60-61 \%$ by acidification treatment ( $\mathrm{S} 4, \mathrm{~S} 10, \mathrm{~S} 12$; Table $5-2)$. These $\mathrm{N}$ recovery percentages however decreased to $48 \%$ with incineration (S8) and to $52 \%$ with nitrification-denitrification (S5) and slow pyrolysis (S9). Other technologies changed only marginally $\mathrm{N}$ recovery (Table $5-2)$.

For specific treatment systems (treated manure), the $\mathrm{N}$ recovery varied from $2 \%$ (through incineration) to $87 \%$ (through acidification). The N/P ratio varied from 3.4 to 10.7 in liquid manure products from treatment, compared to a mean of 3.5 in raw slurry. For solid manure products, the N/P ratio ranged from 0.1 to 3.2 , compared to 3.0 in raw solid manure (Table 52).

Uncertainty. The uncertainty (expressed as coefficient of variation) was $16 \%$ for total $\mathrm{NH}_{3}$ emissions, $20 \%$ for GHG emissions and $6 \%$ for the $\mathrm{N}$ recovery in 2010. Parameters related to emissions from housing and storages are the main factor contributing to the overall uncertainty in total $\mathrm{NH}_{3}$ emissions $(70 \%)$ and GHG emissions (39\%). Parameters related to emissions from manure application contributed $50 \%$ to the overall GHG emission uncertainty. Manure treatment activity data and associated emission parameters contributed less than $1 \%$ to the overall emission uncertainty in 2010 (Figure S1).

The differences in emissions between reference and scenarios were statistically significant, except for S1-3 (separation techniques and anaerobic digestion; regarding $\mathrm{NH}_{3}$ emissions) and for S6 (composting; both $\mathrm{NH}_{3}$ and GHG emissions) (Figure 5-3). 
Table 5-2. Amounts of nitrogen $(\mathrm{N})$ and phosphorus $(\mathrm{P})$ in manure applied to land in the EU-27 in 2010 and in scenarios ${ }^{\mathrm{a}}$. Amounts are expressed in percent of the amounts of $\mathrm{N}$ and $\mathrm{P}$ excreted in housing (i.e. $\mathrm{N}$ and $\mathrm{P}$ recovery).

\begin{tabular}{|c|c|c|c|c|c|c|}
\hline & \multicolumn{2}{|c|}{$\begin{array}{c}\text { All manure } \\
\text { (treated and untreated) }\end{array}$} & \multicolumn{4}{|c|}{ Treated manure } \\
\hline & \multirow{2}{*}{$\begin{array}{c}\text { N recovery } \\
(\%)\end{array}$} & \multirow{2}{*}{$\begin{array}{c}\text { P recovery } \\
(\%)\end{array}$} & \multirow{2}{*}{$\begin{array}{c}\text { N recovery } \\
(\%)\end{array}$} & \multirow{2}{*}{$\begin{array}{c}\text { P recovery } \\
(\%)\end{array}$} & \multicolumn{2}{|c|}{$\mathrm{N} / \mathrm{P}$ ratio in manure products ${ }^{\mathrm{b}}$} \\
\hline & & & & & Liquid form & Solid form \\
\hline In 2010 & 57 & 98 & $-{ }^{c}$ & - & 3.5 (untreated) & 3.0 (untreated) \\
\hline \multicolumn{7}{|l|}{ Scenarios: single technique, slurry } \\
\hline S1: Screw press & 58 & 98 & 63 & 100 & 3.6 & 2.0 \\
\hline S2: Decanter centrifuge & 58 & 98 & 61 & 100 & 7.5 & 1.2 \\
\hline S3: Anaerobic digestion (AD) & 58 & 98 & 62 & 100 & $3.4 ; 5.0$ & 1.2 \\
\hline S4: Acidification (Acid) & 61 & 98 & 87 & 100 & 4.4 & - \\
\hline S5: Nitrification-denitrification & 52 & 98 & 33 & 100 & 8.6 & $2.9 ; 1.1$ \\
\hline \multicolumn{7}{|c|}{ Scenarios: single technique, solid manure } \\
\hline S6: Composting & 58 & 99 & 60 & 100 & & 3.2 \\
\hline S7: Thermal drying & 58 & 99 & 57 & 100 & & 3.1 \\
\hline S8: Incineration & 48 & 99 & 2 & 100 & & 0.1 \\
\hline S9: Pyrolysis & 52 & 99 & 25 & 100 & & 2.1 \\
\hline \multicolumn{7}{|c|}{ Scenarios: combined techniques, slurry } \\
\hline S10: Acid-centrifuge & 61 & 98 & 84 & 100 & 10.7 & 1.5 \\
\hline S11: Centrifuge-acid, pyrolysis & 57 & 98 & 61 & 100 & 9.7 & 0.5 \\
\hline S12: AD-acid-centrifuge & 60 & 98 & 74 & 100 & 10.0 & 1.4 \\
\hline
\end{tabular}

${ }^{a}$ Emissions of ammonia were subtracted from the $\mathrm{N}$ in applied manure for calculating the $\mathrm{N}$ recovery; ${ }^{\mathrm{b}}$ manure products from respective treatment technologies are explained in Table 5-1 (liquid manure products from AD include digested slurry and liquid fraction separated from digestate; solid manure products from nitrification-denitrification include sludge and solid fraction separated from slurry). ${ }^{c}$ not applicable 


\section{Chapter 5}

\subsection{Discussion}

Manure treatment in EU. Anaerobic digestion and solid-liquid separation are by far the most popular treatment technologies in Europe, and anaerobic digestion had the largest contribution to overall GHG mitigation of all treatment technologies (Figure 5-2). Germany and Denmark have been most successful in promoting anaerobic digestion. The success is due to national government support (e.g. investment support for construction and subsidies on bioenergy delivery) and the enforcement of EU environmental regulations (e.g. Nitrates Directive, Renewable Energy Directive) (Edwards et al., 2015). The Danish government proposed a target of using 50\% of the manure produced for renewable energy by 2020 , which would essentially be met through an expansion of biogas plants (Danish Agrifish Agency). Slurry separation has been adopted by livestock farms in many EU countries (particularly in Italy and Portugal), where GHG emissions might be decreased due to the adoption of this technique (Figure 5-2). This reduction is mainly because of the lower $\mathrm{CH}_{4}$ emissions from storage of separated solid fractions relative to that from storage of raw slurry, which is in line with other whole-farm scale assessment (Sommer et al., 2009). Also, we assumed that separation is near the source of production, i.e. the slurry was not stored prior to separation. Anaerobic digestion and slurry separation have not changed $\mathrm{NH}_{3}$ emissions much (Figure 5-2).

The adoption of other treatment technologies was concentrated in a few specific countries, therefore their contributions were limited at EU scale. Slurry acidification with the purpose of $\mathrm{NH}_{3}$ abatement also reduces $\mathrm{CH}_{4}$ emissions from slurry during storage (Hou et al., 2015). The reduction in $\mathrm{CH}_{4}$ emissions is attributed to the inhibition of methanogenesis, because of the acidic conditions and the high concentrations of sulphate (which is an electron acceptor) and sulphide (which is toxic) (Ottosen et al., 2009; Petersen et al., 2012). However, this technique is only used in Denmark. Poultry incineration occurs in Netherlands and UK; there is evidence that $\mathrm{CH}_{4}$ and $\mathrm{N}_{2} \mathrm{O}$ emissions are negligible, while the electricity production 'saves' emissions by replacement of fossil fuel combustion (Billen et al., 2015). Composting occurs in many countries in small scale units; a meta-analysis indicates that composting tends to decrease $\mathrm{N}_{2} \mathrm{O}$ and $\mathrm{CH}_{4}$ emissions compared to conventional static storage of solid waste, yet with large variations in the magnitude of decrease (Pardo et al., 2015). Although manure treatment is on average still marginal in Europe, most techniques (e.g. anaerobic digestion, acidification, incineration) contribute to significant decreases in GHG emissions and/or $\mathrm{NH}_{3}$ emissions. This indicates the importance of taking manure treatment into account for national emission inventories. 
Implications of scenario analyses. Our scenario analyses indicate that processing an equivalent of $20 \%$ of total manure production from housings will decrease $\mathrm{NH}_{3}$ emissions by 0 to $11 \%$ and will alter GHG emissions by -20 to $+6 \%$ from the manure management chain in EU-27, relative to the reference (Figure 5-3). Both $\mathrm{NH}_{3}$ and GHG emissions decreased relatively strong in scenarios with acidification (S4, S10-12), and to a lesser extent also with thermal drying (S7), incineration (S8) and pyrolysis (S9) (Figure 5-3).

Manure $\mathrm{N}$ is a major source $(81 \%)$ of $\mathrm{NH}_{3}$ emissions from agriculture in Europe. It has been reported that implementation of an optimal combination of $\mathrm{NH}_{3}$ mitigation measures (covered manure storages, low-emission application etc.) may decrease total $\mathrm{NH}_{3}$ emissions in EU-27 by $316 \mathrm{Gg} N$ (Oenema et al., 2009). Our results suggest that manure treatment, implemented to treat $20 \%$ of total manure production from housings, have comparable emission abatement (180-275 Gg N, referring to S4-5, S7-12). Some manure treatment technologies may also have relatively large potential to mitigate GHG emissions (Figure 5-3), compared to conventional $\mathrm{NH}_{3}$ abatement measures that minimally affect $\mathrm{CH}_{4}$ and $\mathrm{N}_{2} \mathrm{O}$ emissions, or increase $\mathrm{N}_{2} \mathrm{O}$ emissions (Oenema et al., 2009; Velthof et al., 2009).

Nitrification-denitrification treatment increased GHG emissions because of the increased $\mathrm{N}_{2} \mathrm{O}$ emissions from the reactor, while $\mathrm{CH}_{4}$ emissions decreased (Figure 5-3). Emissions of $\mathrm{N}_{2} \mathrm{O}$ from nitrification-denitrification may range from 1 to $20 \%$ of the slurry $\mathrm{N}$ input (Willers et al., 1996; Béline \& Martinez, 2002; Loyon et al., 2007; Melse \& Timmerman, 2009). The IPCC default $\mathrm{N}_{2} \mathrm{O}$ EFs for raw slurry in storages have a much smaller range: 0-0.5\% (IPCC, 2006). Emissions of $\mathrm{N}_{2} \mathrm{O}$ from nitrification-denitrification treatment may be decreased by increasing the residence time of the slurry in the denitrification reactor or by a better control of the molasses addition (through measurement of the redox potential) (Béline \& Martinez, 2002; Melse \& Verdoes, 2005). These unwanted side effects have to be minimized; this is especially important for Brittany (France) and Flanders (Belgium) where this technique has been implemented to decrease the manure N surplus (Bernet \& Béline, 2009).

Increasing the efficiency of manure $\mathrm{N}$ and $\mathrm{P}$ use as fertilizer is economically beneficial because it lowers the need for chemical fertilizers. However, scenarios with nitrificationdenitrification (S5), incineration (S8) and slow pyrolysis (S9) indicate a low recovery fraction available for application to land (Table 5-2). These technologies cannot be considered as sustainable from a resource use efficiency point of view, as they convert the majority of $\mathrm{N}$ (about $65 \%$ to $100 \%$ ) to a form (dinitrogen gas) that cannot be utilized anymore for 


\section{Chapter 5}

fertilization (Melse \& Timmerman, 2009; Billen et al., 2015). During these treatments (S5, S8-9) a significant fraction of the carbon in the manure is also lost, and thus less organic matter is available for improving soil quality. In the scenario with manure incineration, the $\mathrm{N}$ loss equals to $8 \%$ of mineral $\mathrm{N}$ fertilizer consumed in EU in 2010. In livestock-rich regions that produce more manure $\mathrm{N}$ than crops need, these technologies may help to lower manure $\mathrm{N}$ surpluses. For scenarios with acidification (S4, S10, S12), the manure N recovery increased because of the $\mathrm{N}$ saved from volatilization (Table 5-2). The $\mathrm{N}$ availability in acidified slurry increases the $\mathrm{N}$ fertilizer equivalent value, by about $25 \%$ compared to raw slurry (Kai et al., 2008; Sørensen \& Eriksen, 2009).

Phosphate rock as a non-renewable resource is scarce especially in EU where more than 95\% of mineral P fertilizer used has been imported from outside EU (van Dijk et al., 2015). For all manure treatment scenarios, we estimated that the total P recovery did not decrease (Table 52). Nevertheless, the $P$ availability for crops (in terms of first year P fertilizer equivalent value) varies, from less than $20 \%$ for ash residues to $80 \%-100 \%$ for acidified slurry or separated liquid fractions (Sommer et al., 2013). Manure treatment generates manure products that vary in the ratios between nutrient (e.g. N, P and potassium), such as the N/P ratios (0.1-10.7; Table 5-2). This provides opportunities to better use manure and to better meet crop nutrient demands. Depending on between-farm variations in crop rotations and soil fertility, farmers may choose the manure product with the appropriate N/P ratio.

Green energy production from anaerobic digestion and incineration of animal manure can be viewed as pathways to contribute to achieving the EU Renewable Energy target; at least 27\% of the total energy needs have to come from renewables by 2030 (European Commission, 2009). Green energy production leads to $\mathrm{CO}_{2}$ emission reduction due to the replacement of heat and electricity produced from fossil fuels. We estimate that the net energy production is 1.7-2.8 Mtoe (Million Tonnes of Oil Equivalent) for the scenario with anaerobic digestion (S3), assuming an energy surplus of 50-80\% in biogas plants, used for heat and electricity cogeneration (Sommer et al., 2009; Miranda et al., 2015). The avoided $\mathrm{CO}_{2}$ emissions from fossil fuels are 7.6-12.1 $\mathrm{Tg} \mathrm{CO}$-eq, assuming an emission factor of $0.102 \mathrm{~kg} \mathrm{CO}_{2} \mathrm{MJ}^{-1}$ for power production from coals (Sommer et al., 2009; Miranda et al., 2015). This is equivalent to $9-14 \%$ of GHG emissions estimated for the manure management chain in EU-27 in 2010.

Our scenario analyses illustrate that various treatment technologies can be viewed as measures to mitigate $\mathrm{GHG}$ and/or $\mathrm{NH}_{3}$ emissions from the manure management chain. 
Increasing the implementation of these technologies in practice may contribute to achieving the $\mathrm{NH}_{3}$ emission targets of the National Emission Ceiling Directive (Directive 2001/81/EC), and the GHG emission targets of the Kyoto Protocol (UNFCCC). Slurry acidification, incineration and pyrolysis are technologies that reduce both $\mathrm{NH}_{3}$ and GHG emissions. Acidification also increases the $\mathrm{N}$ recovery, while incineration and pyrolysis may reduce manure $\mathrm{N}$ surpluses in regions with high animal density. Solid-liquid separation produces manure products with diverse $\mathrm{N}$ and $\mathrm{P}$ contents, which allows farmers to better meet cropspecific nutrient demands. Combing anaerobic digestion with acidification or with other $\mathrm{NH}_{3}$ mitigation measures (for storage of digested slurry) is needed to achieve abatement of both GHG and $\mathrm{NH}_{3}$ emissions.

\section{Acknowledgments}

This research has received funding from the People Programme (Marie Curie Actions) of the European Union's Seventh Framework Programme FP7/2007-2013/under REA grant agreement no 289887. The results and conclusions achieved reflect only the author's view and the Union is not liable for any use that may be made of the information contained therein. 


\section{Chapter 5}

\section{Supporting information:}

Table S1. The calculated nutrient excretion by the livestock in the EU-27 in 2010.

\begin{tabular}{|c|c|c|c|c|c|c|c|c|c|c|}
\hline \multirow[t]{2}{*}{ Country } & \multicolumn{4}{|c|}{ Total excretion $(\mathrm{Gg})$} & \multicolumn{4}{|c|}{$\begin{array}{l}\text { Manure management systems } \\
\text { (\% of total } \mathrm{N} \text { excretion) }\end{array}$} & \multirow{2}{*}{$\begin{array}{l}\text { The amount of } \mathrm{N} \\
\text { excretion being } \\
\text { treated, as \% of total } \\
\mathrm{N} \text { excreted in housing }\end{array}$} & \multirow{2}{*}{$\begin{array}{l}\mathrm{N} \text { applied to land, } \\
\text { as \% of } \mathrm{N} \text { excreted } \\
\text { in housing }\end{array}$} \\
\hline & Nitrogen & Phosphorus & $\begin{array}{l}\text { Volatile } \\
\text { solid }^{\mathrm{a}}\end{array}$ & Carbon $^{\mathrm{a}}$ & Grazing & $\begin{array}{l}\begin{array}{l}\text { Housing } \\
\text { (slurry) }\end{array} \\
\end{array}$ & $\begin{array}{l}\text { Housing } \\
\text { (solid) }\end{array}$ & $\begin{array}{l}\text { Daily } \\
\text { spreading }\end{array}$ & & \\
\hline Austria & 187 & 32 & 2980 & 1518 & 5 & 37 & 58 & 0 & 6 & 60 \\
\hline Belgium & 238 & 42 & 3386 & 1743 & 28 & 42 & 29 & 1 & 12 & 62 \\
\hline Bulgaria & 69 & 14 & 1248 & 639 & 22 & 6 & 72 & 0 & $<0.1$ & 57 \\
\hline Cyprus & 14 & 3 & 189 & 99 & 0 & 32 & 68 & 0 & 8 & 56 \\
\hline Czech. Rep & 122 & 23 & 2237 & 1144 & 13 & 35 & 51 & 1 & 1 & 56 \\
\hline Denmark & 253 & 53 & 2952 & 1537 & 8 & 74 & 18 & 0 & 13 & 68 \\
\hline Estonia & 24 & 4 & 420 & 213 & 32 & 25 & 44 & 0 & 2 & 54 \\
\hline Finland & 81 & 15 & 1189 & 610 & 11 & 49 & 41 & 0 & 2 & 64 \\
\hline France & 1730 & 282 & 26047 & 13263 & 45 & 27 & 29 & 0 & 1 & 55 \\
\hline Germany & 1235 & 224 & 19809 & 10166 & 10 & 59 & 31 & 0 & 9 & 63 \\
\hline Greece & 136 & 28 & 2261 & 1151 & 59 & 7 & 33 & 0 & 18 & 53 \\
\hline Hungary & 111 & 24 & 1943 & 1019 & 9 & 16 & 75 & 0 & $<0.1$ & 53 \\
\hline Ireland & 468 & 69 & 6676 & 3357 & 61 & 29 & 10 & 0 & $<0.1$ & 56 \\
\hline Italy & 870 & 145 & 14743 & 7558 & 10 & 39 & 50 & 0 & 12 & 56 \\
\hline Latvia & 39 & 6 & 745 & 377 & 29 & 25 & 47 & 0 & $<0.1$ & 54 \\
\hline Lithuania & 72 & 12 & 1251 & 634 & 30 & 25 & 45 & 0 & $<0.1$ & 54 \\
\hline Luxembourg & 12 & 2 & 192 & 96 & 45 & 38 & 17 & 0 & 8 & 58 \\
\hline Malta & 3 & 1 & 33 & 18 & 0 & 28 & 72 & 0 & $<0.1$ & 53 \\
\hline Netherlands & 548 & 87 & 6789 & 3523 & 13 & 67 & 19 & 0 & 8 & 61 \\
\hline Poland & 606 & 115 & 11015 & 5681 & 7 & 10 & 83 & 0 & $<0.1$ & 53 \\
\hline Portugal & 176 & 28 & 2772 & 1426 & 52 & 16 & 32 & 0 & 2 & 52 \\
\hline Romania & 360 & 69 & 6699 & 3412 & 42 & 11 & 45 & 2 & 5 & 54 \\
\hline Slovakia & 53 & 9 & 949 & 486 & 13 & 12 & 74 & 0 & $<0.1$ & 54 \\
\hline Slovenia & 33 & 6 & 667 & 338 & 12 & 56 & 32 & 0 & 1 & 56 \\
\hline Spain & 972 & 168 & 15286 & 7856 & 45 & 24 & 31 & 0 & 5 & 55 \\
\hline Sweden & 169 & 25 & 2434 & 1237 & 30 & 35 & 35 & 0 & $<0.1$ & 59 \\
\hline United Kingdom & 1131 & 181 & 16877 & 8592 & 57 & 13 & 30 & 1 & 6 & 54 \\
\hline EU-27 & 9716 & 1669 & 151790 & 77691 & 31 & 32 & 36 & $<0.5$ & 6 & 57 \\
\hline
\end{tabular}

${ }^{\mathrm{a}}$ VS per animal category and country was determined as function of feed VS intake and VS digestibility (IPCC, 2006; CSIRO, 2007; Hou et al., 2016). The constant ratios of TC/VS in excretion ( 0.5 for ruminants, 0.54 for pigs and 0.58 for poultry) were used to quantify carbon content in excretion. 
Table S2 Emission factors of ammonia $\left(\mathrm{NH}_{3}\right)$, nitrous oxide $\left(\mathrm{N}_{2} \mathrm{O}\right)$, dinitrogen $\left(\mathrm{N}_{2}\right)$ and nitrogen oxides $\left(\mathrm{NO}_{\mathrm{x}}\right)$ from animal manure in the EU-27 at country levels in 2010, based on the model MITERRA-Europe (Velthof et al., 2009; Lesschen et al., 2011) and additional calculations.

\begin{tabular}{|c|c|c|c|c|c|c|c|c|}
\hline \multirow[t]{2}{*}{ Country } & \multicolumn{4}{|l|}{$\mathrm{NH}_{3}$} & \multicolumn{3}{|l|}{$\mathrm{N}_{2} \mathrm{O}$} & \multirow{2}{*}{$\begin{array}{l}\mathrm{N}_{2} \text { and } \mathrm{NO}_{\mathrm{x}} \\
\text { Storage of raw } \\
\text { manure (\% } \mathrm{N} \\
\text { excreted in housing) }\end{array}$} \\
\hline & $\begin{array}{l}\text { Housing } \\
(\% \mathrm{~N} \text { excreted } \\
\text { in housing) }\end{array}$ & $\begin{array}{l}\text { Storage of } \\
\text { (raw) manure } \\
(\% \text { of } \mathrm{N} \text { in } \\
\text { storage })\end{array}$ & $\begin{array}{l}\text { Raw manure } \\
\text { application } \\
\text { (\% of } \mathrm{N} \\
\text { applied) }\end{array}$ & $\begin{array}{l}\text { Grazing } \\
\text { (\% of } \mathrm{N} \text { deposited } \\
\text { by grazing } \\
\text { animals) }\end{array}$ & $\begin{array}{l}\text { Storage of } \\
\text { (raw) manure } \\
(\% \mathrm{~N} \text { in } \\
\text { storage })\end{array}$ & $\begin{array}{l}\text { Raw manure } \\
\text { application } \\
\text { (\% of } \mathrm{N} \\
\text { applied) }\end{array}$ & $\begin{array}{l}\text { Grazing } \\
\text { (\% of } \mathrm{N} \text { excreted } \\
\text { by grazing } \\
\text { animals) }\end{array}$ & \\
\hline Austria & 13 & 5 & 19 & 7 & 0.38 & 1.0 & 1.8 & 7 \\
\hline Belgium & 13 & 5 & 14 & 8 & 0.34 & 1.2 & 2.0 & 5 \\
\hline Bulgaria & 13 & 6 & 18 & 8 & 0.38 & 1.1 & 1.4 & 10 \\
\hline Cyprus & 12 & 13 & 14 & & 0.36 & 1.2 & & 8 \\
\hline Czech. Rep & 14 & 12 & 16 & 8 & 0.32 & 1.2 & 1.9 & 7 \\
\hline Denmark & 9 & 11 & 10 & 7 & 0.26 & 1.5 & 2.0 & 3 \\
\hline Estonia & 13 & 12 & 19 & 8 & 0.37 & 1.0 & 2.0 & 7 \\
\hline Finland & 12 & 10 & 12 & 8 & 0.33 & 1.1 & 2.0 & 5 \\
\hline France & 13 & 12 & 18 & 8 & 0.30 & 1.1 & 1.9 & 6 \\
\hline Germany & 15 & 13 & 12 & 8 & 0.29 & 1.2 & 1.9 & 5 \\
\hline Greece & 13 & 14 & 18 & 4 & 0.31 & 1.1 & 1.1 & 10 \\
\hline Hungary & 14 & 14 & 16 & 6 & 0.34 & 1.2 & 1.6 & 9 \\
\hline Ireland & 18 & 8 & 20 & 8 & 0.38 & 1.0 & 1.9 & 4 \\
\hline Italy & 12 & 12 & 19 & 5 & 0.31 & 1.2 & 1.2 & 7 \\
\hline Latvia & 13 & 12 & 19 & 8 & 0.36 & 1.1 & 2.0 & 7 \\
\hline Lithuania & 13 & 12 & 19 & 8 & 0.37 & 1.1 & 2.0 & 7 \\
\hline Luxembourg & 13 & 10 & 20 & 8 & 0.32 & 1.0 & 2.0 & 4 \\
\hline Malta & 15 & 9 & 20 & & 0.32 & 1.0 & & 8 \\
\hline Netherlands & 10 & 8 & 13 & 7 & 0.22 & 1.6 & 1.9 & 3 \\
\hline Poland & 15 & 13 & 14 & 8 & 0.38 & 1.1 & 2.0 & 9 \\
\hline Portugal & 14 & 15 & 18 & 7 & 0.24 & 1.1 & 1.8 & 7 \\
\hline Romania & 13 & 12 & 17 & 8 & 0.41 & 1.0 & 1.6 & 9 \\
\hline Slovakia & 12 & 12 & 17 & 7 & 0.38 & 1.2 & 1.7 & 9 \\
\hline Slovenia & 14 & 7 & 22 & 5 & 0.32 & 1.0 & 1.8 & 5 \\
\hline Spain & 13 & 15 & 15 & 8 & 0.30 & 1.3 & 1.7 & 7 \\
\hline Sweden & 13 & 11 & 14 & 8 & 0.33 & 1.2 & 2.0 & 6 \\
\hline United Kingdom & 15 & 11 & 15 & 4 & 0.36 & 1.2 & 1.6 & 8 \\
\hline
\end{tabular}




\section{Chapter 5}

Table S3 Summary of key parameters and data sources used for the environmental assessment of manure treatment technologies in this study.

\begin{tabular}{|c|c|c|c|c|}
\hline $\begin{array}{l}\text { Manure treatment } \\
\text { technologies }\end{array}$ & Parameter codes & $\begin{array}{l}\text { Values used in } \\
\text { the model }\end{array}$ & Description & Data sources \\
\hline \multirow[t]{4}{*}{ Acidification } & $\mathrm{Re}_{\text {build_acid_NH3 }}$ & $65 \%$ & \multirow{4}{*}{$\begin{array}{l}\mathrm{NH}_{3} \text { and } \mathrm{CH}_{4} \text { reduction factors during in- } \\
\text { house }\left(\mathrm{Re}_{\text {build_acid }}\right) \text {, outdoor storage } \\
\left.\left(\mathrm{Re}_{\text {storage_acid }}\right) \text {, and application ( } \mathrm{Re}_{\text {applic_acid }}\right) \\
\text { of acidified slurry, relative to raw slurry }\end{array}$} & (Kai et al., 2008; Petersen et al., 2016) \\
\hline & $\mathrm{Re}_{\text {storage_acid_NH3 }}$ & $83 \%$ & & (Hou et al., 2015) \\
\hline & $\mathrm{Re}_{\text {storage_acid_CH4 }}$ & $87 \%$ & & (Hou et al., 2015) \\
\hline & $\mathrm{Re}_{\text {applic_acid_NH3 }}$ & $40 \%$ & & (Kai et al., 2008; Fangueiro et al., 2015a, 2015b) \\
\hline \multirow{11}{*}{$\begin{array}{l}\text { Solid-liquid } \\
\text { Separation }\end{array}$} & $\mathrm{Et}_{\text {sep_N }}$ & $10 \% ; 22 \%$ & \multirow{6}{*}{$\begin{array}{l}\text { Separation efficiency }\left(\mathrm{Et}_{\mathrm{sep}}\right) \text { of } \mathrm{N}, \mathrm{P} \text { and } \\
\mathrm{VS} \text {, for i) screw and filter pressing; ii) } \\
\text { combined with coagulation/ flocculation } \\
\text { i) non-pressurized filtration; ii) combined } \\
\text { with coagulation/ flocculation }\end{array}$} & \multirow{9}{*}{$\begin{array}{l}\text { (Møller et al., 2007b, 2000, 2002, 2007a; Converse \& } \\
\text { Karthikeyan, 2004; Melse \& Verdoes, 2005; Rico et al., } \\
\text { 2007; Campos et al., 2008; Fangueiro et al., 2008, 2009; } \\
\text { Hjorth et al., 2010; Hamelin et al., 2011; Popovic et al., } \\
\text { 2012) }\end{array}$} \\
\hline & $\mathrm{Et}_{\text {sep_P }}$ & $15 \% ; 32 \%$ & & \\
\hline & $\mathrm{Et}_{\text {sep_Vs }}$ & $29 \% ; 55 \%$ & & \\
\hline & $\mathrm{Et}_{\text {sep_N } \mathrm{N}}$ & $33 \% ; 47 \%$ & & \\
\hline & $\mathrm{Et}_{\text {sep_P }}$ & $41 \% ; 81 \%$ & & \\
\hline & $\mathrm{Et}_{\text {sep_Vs }}$ & $49 \% ; 76 \%$ & & \\
\hline & $\mathrm{Et}_{\text {sep_N }}$ & $26 \% ; 47 \%$ & \multirow{3}{*}{$\begin{array}{l}\text { i) centrifugation and sedimentation; ii) } \\
\text { combined with coagulation/ flocculation }\end{array}$} & \\
\hline & $\mathrm{Et}_{\text {sep_P }}$ & $69 \% ; 81 \%$ & & \\
\hline & $\mathrm{Et}_{\mathrm{sep} \_\mathrm{VS}}$ & $58 \% ; 76 \%$ & & \\
\hline & $\mathrm{Re}_{\text {applic_LF_NH3 }}$ & $18 \%$ & $\begin{array}{l}\mathrm{NH}_{3} \text { reduction factors for application of } \\
\text { liquid fraction, relative to raw manure }\end{array}$ & (Hou et al., 2015) \\
\hline & $\mathrm{Re}_{\text {applic_SF_N2O }}$ & $45 \%$ & $\begin{array}{l}\mathrm{N}_{2} \mathrm{O} \text { reduction factors for application of } \\
\text { solid fraction, relative to raw manure }\end{array}$ & (Hou et al., 2015) \\
\hline \multirow[t]{7}{*}{ Anaerobic digestion } & $\mathrm{f}_{\text {biogas_leak }}$ & $1 \%$ & Biogas leakage, $\%$ of biogas production & (Miranda et al., 2015) \\
\hline & $\mathrm{f}_{\text {biogas_CH4 }}$ & $55-65 \%$ & $\mathrm{CH}_{4}$ in biogas composition & (Hamelin et al., 2011; UNFCCC) \\
\hline & If $_{\text {storage_dig_NH3 }}$ & $50 \%$ & $\begin{array}{l}\text { Increase in } \mathrm{NH}_{3} \text { emission from storage of } \\
\text { digested slurry, relative to raw slurry }\end{array}$ & (Sommer, 1997; Clemens et al., 2006; Koirala et al., 2013) \\
\hline & $\mathrm{Re}_{\text {storage_dig_CH4 }}$ & $78.5 \%$ & $\begin{array}{l}\mathrm{CH}_{4} \text { reduction factors from storage of } \\
\text { digested slurry, relative to raw slurry; } \mathrm{N}_{2} \mathrm{O} \\
\text { emissions are assumed to be unchanged. }\end{array}$ & (Miranda et al., 2015) \\
\hline & $f_{\text {Deg_vs }}$ & $0.45-0.6$ & $\begin{array}{l}\text { Degradable rates of VS of manure in } \\
\text { digester, varied among animal categories }\end{array}$ & (Møller et al., 2004a, 2004b; Hamelin et al., 2011, 2014) \\
\hline & $\mathrm{Re}_{\text {applic_dig.LF_NH3 }}$ & $18 \%$ & $\begin{array}{l}\mathrm{NH}_{3} \text { reduction factors for application of } \\
\text { digested liquid fraction; } \mathrm{NH}_{3} \mathrm{EF} \text { from } \\
\text { digested slurry are considered to be same } \\
\text { as raw manure. }\end{array}$ & (Hou et al., 2015) \\
\hline & $\mathrm{Re}_{\text {applic_dig/dig.LF_N2O }}$ & $25 \%$ & $\begin{array}{l}\mathrm{N}_{2} \mathrm{O} \text { reduction factors for application of } \\
\text { digested slurry and liquid fraction Of } \\
\text { digestate. }\end{array}$ & (Hou et al., 2015) \\
\hline
\end{tabular}




\begin{tabular}{|c|c|c|c|c|}
\hline \multirow{11}{*}{$\begin{array}{l}\text { Nitrification and } \\
\text { denitrification } \\
\text { treatment (NDN) }\end{array}$} & $\mathrm{EF}_{\mathrm{NDN} \_\mathrm{N} 2 \mathrm{O}}$ & $9 \%$ & $\begin{array}{l}\mathrm{N}_{2} \mathrm{O} \text { emission factor }(\mathrm{EF}) \text { during } \mathrm{NDN} ; \mathrm{a} \\
\text { range } 1-20 \% \text { was reported in literature }\end{array}$ & $\begin{array}{l}\text { (Willers et al., 1996; Béline \& Martinez, 2002; Melse \& } \\
\text { Verdoes, 2005; Loyon et al., 2007) }\end{array}$ \\
\hline & $\mathrm{EF}_{\mathrm{NDN} \_\mathrm{NH} 3}$ & $0.5 \%$ & $\mathrm{NH}_{3}$ EF during NDN; a range $0.1-0.8 \%$ & (Willers et al., 1996; Melse \& Verdoes, 2005) \\
\hline & $\mathrm{EF}_{\mathrm{NDN} \_\mathrm{TN}}$ & $70 \%$ & Total $\mathrm{N}$ loss during NDN, a range $52-80 \%$ & $\begin{array}{l}\text { (Béline \& Martinez, 2002; Beline et al., 2008; Riaño \& } \\
\text { García-González, 2014) }\end{array}$ \\
\hline & $\mathrm{EF}_{\mathrm{NDN} \_\mathrm{CO} 2}$ & $15 \%$ & $\mathrm{CO}_{2}$ EF during NDN; a range $52-80 \%$ & (Loyon et al., 2007) \\
\hline & $\mathrm{EF}_{\mathrm{NDN} \_\mathrm{CH} 4}$ & $0.25 \%$ & $\mathrm{CH}_{4}$ EF during NDN; a range $0.04-0.34 \%$ & (Melse \& Verdoes, 2005; Loyon et al., 2007) \\
\hline & $\mathrm{EF}_{\mathrm{NDN} \_s l u d \_C H 4}$ & $0.5 \%$ & $\mathrm{CH}_{4} \mathrm{EF}$ during storage of sludge & (Loyon et al., 2007) \\
\hline & $\mathrm{EF}_{\mathrm{NDN} \_s l u d \_N H 3}$ & $1.5 \%$ & $\mathrm{NH}_{3}$ EF during storage of sludge & (Loyon et al., 2007) \\
\hline & $\mathrm{EF}_{\mathrm{NDN} \_ \text {slud_N2O }}$ & $0.1 \%$ & $\mathrm{~N}_{2} \mathrm{O}$ EF during storage of sludge & Assumption \\
\hline & EF $_{\text {NDN_slud_N2 }}$ & $0.5 \%$ & $\mathrm{~N}_{2}$ EF during storage of sludge & Assumption \\
\hline & EF $_{\text {applic_NDN_slud_NH3 }}$ & $1 \%$ & $\mathrm{NH}_{3}$ EF during application of sludge & \\
\hline & $\mathrm{Re}_{\text {applic_SF_N2O }}$ & $45 \%$ & $\begin{array}{l}\mathrm{N}_{2} \mathrm{O} \text { reduction factors for application of } \\
\text { sludge, relative to raw manure, considered } \\
\text { same as separated solid fraction }\end{array}$ & (Hou et al., 2015) \\
\hline \multirow[t]{6}{*}{ Composting } & If $f_{\text {compost_NH3 }}$ & $52 \%$ & \multirow{4}{*}{$\begin{array}{l}\text { Increasing factors }\left(\mathrm{If}_{\text {compost }}\right) \text { or reduction } \\
\text { factors }\left(\mathrm{Re}_{\text {compost }}\right) \text { for emissions during } \\
\text { composting, relative to conventional } \\
\text { storage }\end{array}$} & \multirow[t]{4}{*}{ (Pardo et al., 2015) } \\
\hline & If $f_{\text {compost_CO2 }}$ & $38.5 \%$ & & \\
\hline & $\mathrm{Re}_{\text {compost_CH} 4}$ & $71 \%$ & & \\
\hline & $\mathrm{Re}_{\text {compost_N2O }}$ & $49 \%$ & & \\
\hline & $\mathrm{EF}_{\text {applic_compost_NH3 }}$ & $1 \%$ & $\mathrm{NH}_{3}$ EF during application of compost & (Chadwick et al., 2011) \\
\hline & $\mathrm{EF}_{\text {applic_compost_N2O }}$ & $1 \%$ & $\mathrm{~N}_{2} \mathrm{O}$ EF during application of compost & (IPCC, 2006; Chadwick et al., 2011) \\
\hline \multirow[t]{6}{*}{ Incineration } & $\mathrm{EF}_{\text {incinerate_NH3 }}$ & $0.03 \%$ & $\begin{array}{l}\mathrm{NH}_{3} \text { EF of incineration; a range } 0.01- \\
0.06 \%\end{array}$ & (Brassard et al., 2014; Billen et al., 2015) \\
\hline & $\mathrm{EF}_{\text {incinerate_N2O }}$ & $0.3 \%$ & $\mathrm{~N}_{2} \mathrm{O}$ EF of incineration; a range $0.04-0.7 \%$ & $\begin{array}{l}\text { (Brassard et al., 2014; Billen et al., 2015; Fernandez- } \\
\text { Lopez et al., 2015) }\end{array}$ \\
\hline & $\mathrm{EF}_{\text {incinerate_NOx }}$ & $0.35 \%$ & $\mathrm{NO}_{\mathrm{x}}$ EF of incineration; a range $0.1-0.4 \%$ & (Brassard et al., 2014; Billen et al., 2015) \\
\hline & $\mathrm{f}_{\text {incinerate_residue_N }}$ & $2 \%$ & Fraction of $\mathrm{N}$ residue, a range $1.4-4 \%$ & (Christel et al., 2014) \\
\hline & $\mathrm{f}_{\text {incinerate_residue_C }}$ & $1 \%$ & Fraction of $\mathrm{C}$ residue, a range $0.05-2.2 \%$ & $\begin{array}{l}\text { (Brassard et al., 2014; Christel et al., 2014; Fernandez- } \\
\text { Lopez et al., 2015) }\end{array}$ \\
\hline & $\mathrm{EF}_{\text {applic_ash_NH3/N2O }}$ & Negligible & $\mathrm{NH}_{3}$ and $\mathrm{N}_{2} \mathrm{O}$ EF of application of ash & Assumption \\
\hline \multirow[t]{6}{*}{ Thermal drying } & $\mathrm{EF}_{\text {thermal-dry_NH3 }}$ & $\begin{array}{l}\text { Poultry: } 25 \% \text {,Pig: } \\
\text { 30\%,Cattle:30\% }\end{array}$ & $\begin{array}{l}\mathrm{NH}_{3} \text { EFs during drying (Pig: } 25-36 \% ; \\
\text { Cattle: } 25-36 \% \text {; Poultry: } 21-29 \% \text { ) }\end{array}$ & \multirow[t]{3}{*}{$\begin{array}{l}\text { (Sistani et al., 2001; Maurer \& Müller, 2012; Ghaly \& } \\
\text { Alhattab, 2013; Pantelopoulos et al., 2016) }\end{array}$} \\
\hline & $\mathrm{Re}_{\text {dry_scrubber_NH3 }}$ & $85 \%$ & $\begin{array}{l}\mathrm{NH}_{3} \text { reduction factor by air scrubber; a } \\
\text { range } 71-99 \%\end{array}$ & \\
\hline & $\mathrm{EF}_{\text {thermal-dry_N2O }}$ & $0.02 \%$ & $\mathrm{~N}_{2} \mathrm{O}$ EF, a range $0.01-0.5 \%$ & \\
\hline & $\mathrm{EF}_{\text {thermal-dry-NOx }}$ & $0.02 \%$ & $\mathrm{NO}_{\mathrm{x}} \mathrm{EF}$, assumed to be same as $\mathrm{N}_{2} \mathrm{O}$ & Assumption \\
\hline & $\mathrm{EF}_{\text {thermal-dry_N2 }}$ & $5 \%$ & $\mathrm{~N}_{2}$ EF during thermal drying & Assumption \\
\hline & $\mathrm{EF}_{\text {applic_dry_NH3 }}$ & negligible & $\mathrm{NH}_{3}$ EFs during application & (Rodhe \& Karlsson, 2002) \\
\hline
\end{tabular}




\section{Chapter 5}

\begin{tabular}{|c|c|c|c|c|}
\hline \multirow[t]{2}{*}{ Bio-drying } & If $_{\text {biodry_NH3 }}$ & $121 \%$ & $\begin{array}{l}\text { Increase in } \mathrm{NH}_{3} \text { emission during bio- } \\
\text { drying, a range } 28-243 \% \text { was reported in } \\
\text { literature }\end{array}$ & $\begin{array}{l}\text { (Ramirez et al., 2012; Sadaka \& Ahn, 2012; Pardo et al., } \\
\text { 2015) }\end{array}$ \\
\hline & $\mathrm{EF}_{\text {applic_bio-dry_NH3 }}$ & $1 \%$ & $\begin{array}{l}\text { Assumption, considering the limited } \\
\text { available } \mathrm{N} \text { content in dried manure }\end{array}$ & \\
\hline \multirow[t]{5}{*}{ Slow pyrolysis } & $\mathrm{f}_{\text {biochar_C }}$ & $\begin{array}{l}35 \% \text { (pigs); } 44 \% \\
\text { (cattle, poultry) }\end{array}$ & $\begin{array}{l}\text { Fraction of } \mathrm{C} \text { in biochar, as } \% \text { of } \mathrm{C} \text { input; a } \\
\text { range } 32-56 \%\end{array}$ & \multirow{3}{*}{$\begin{array}{l}\text { (Kim et al., 2009; Ro et al., 2010; Cantrell et al., 2012; } \\
\text { Song \& Guo, 2012; Azuara et al., 2013; Li \& Takarada, } \\
\text { 2013; Troy et al., 2013; Wnetrzak et al., 2013; Baniasadi } \\
\text { et al., 2016) }\end{array}$} \\
\hline & $\mathrm{f}_{\text {biochar_N }}$ & $\begin{array}{l}25 \% \text { (pigs); } 30 \% \\
\text { (cattle, poultry) }\end{array}$ & $\begin{array}{l}\text { Fraction of } \mathrm{N} \text { in biochar, as } \% \text { of } \mathrm{N} \text { input a } \\
\text { range } 5-40 \%\end{array}$ & \\
\hline & $\mathrm{f}_{\text {biochar_p }}$ & $99 \%$ & $\begin{array}{l}\text { Fraction of } \mathrm{P} \text { in biochar, as } \% \text { of } \mathrm{P} \text { input a } \\
\text { range of } 97-100 \% \text { was reported }\end{array}$ & \\
\hline & $\mathrm{EF}_{\text {applic_biochar_NH3 }}$ & $1 \%$ & $\mathrm{NH}_{3}$ EFs during application of biochar & \multirow[t]{2}{*}{ (Kookana et al., 2011; Cayuela et al., 2014) } \\
\hline & $\mathrm{EF}_{\text {applic biochar } \mathrm{N} 2 \mathrm{O}}$ & $0.5 \%$ & $\mathrm{~N}_{2} \mathrm{O}$ EFs from application of biochar & \\
\hline
\end{tabular}


Table S4. A summary of uncertainty in model parameters used for the Monte Carlo (uncertainty) analysis (CV= coefficient of variation; SD =Standard deviation). ${ }^{\mathrm{a}}$

\begin{tabular}{|c|c|c|c|c|c|c|c|}
\hline $\begin{array}{l}\text { Parameter codes (if applicable, see } \\
\text { Table S3) }\end{array}$ & Brief description & Group $^{b}$ & $\begin{array}{l}\text { Distribution } \\
\text { type }\end{array}$ & $\mathrm{CV}$ & SD & $\begin{array}{l}\text { Spatial } \\
\text { correlation, } \\
\text { national } \\
\text { level }\end{array}$ & Source (uncertainty) \\
\hline- & Livestock numbers & LAD & normal & 0.05 & & 0.5 & (Zhu et al., 2015) \\
\hline $\mathrm{E}_{\text {xcreta_N }}$ & $\mathrm{N}$ excretion factors & EXE & normal & 0.1 & & 0.5 & (Hou et al., 2016) \\
\hline$E_{\text {xcreta_vs }}$ & VS excretion factors & EXE & normal & 0.1 & & 0.5 & (Hou et al., 2016) \\
\hline $\mathrm{f}_{\mathrm{TC} / \mathrm{VS}}$ & The TC/VS ratio in excretion & EXE & normal & 0.25 & & 1 & This study ${ }^{c}$ \\
\hline $\mathrm{EF}_{\text {build_slurry/solid_NH3 }}$ & $\mathrm{NH}_{3}$ emission factors (EFs) in housing & EFH & normal & 0.25 & & 0.8 & (Zhu et al., 2015) \\
\hline $\mathrm{EF}_{\text {storage_lurry/solid_NH3 }}$ & $\mathrm{NH}_{3} \mathrm{EFs}$ in storage & $\mathrm{EFH}$ & normal & 0.25 & & 0.8 & (Zhu et al., 2015) \\
\hline $\mathrm{EF}_{\text {storage_slurry/solid_N2O }}$ & $\mathrm{N}_{2} \mathrm{O}$ EFs in storage & EFH & Lognormal & & 0.35 & 0.5 & (Zhu et al., 2015) \\
\hline $\mathrm{EF}_{\text {storage_slurry/solid_N2 }}$ & $\mathrm{N}_{2}$ EFs in storage & EFH & Lognormal & & 0.5 & 0.5 & (Zhu et al., 2015) \\
\hline $\mathrm{MCF}_{\text {slurry/solid }}$ & Methane conversion factors & EFH & normal & 0.25 & & 0.8 & (Zhu et al., 2015) \\
\hline $\mathrm{f}_{\text {acid_slurry }}$ & Fractions of acidified slurry & TAD & normal & 0.25 & & 0.2 & This study \\
\hline $\mathrm{f}_{\text {separate/compost/thermal-}{ }^{-} \text {dry/biodry_slurry }}$ & $\begin{array}{l}\text { Fractions of slurry used for separation, } \\
\text { composting, thermal or bio-drying }\end{array}$ & TAD & normal & 0.25 & & 0.2 & This study \\
\hline $\mathrm{f}_{\mathrm{AD} \_ \text {slurry }}$ & Fractions of slurry used for anaerobic digestion & TAD & normal & 0.25 & & 0.2 & This study \\
\hline $\mathrm{f}_{\text {compost/incineration/thermal- }{ }^{-} \text {dry_solid/biodry_solid }}$ & $\begin{array}{l}\text { Fractions of solid manure used for incineration, } \\
\text { composting, thermal or bio-drying }\end{array}$ & TAD & normal & 0.25 & & 0.2 & This study \\
\hline $\mathrm{Re}_{\text {storage_acid_NH3 }}$ & $\mathrm{NH}_{3}$ reduction factor, acidification & EFT & normal & 0.47 & & 1 & (Hou et al., 2015) \\
\hline $\mathrm{Re}_{\text {storage_acid_CH4 }}$ & $\mathrm{CH}_{4}$ reduction factor, acidification & EFT & normal & 0.44 & & 1 & (Hou et al., 2015) \\
\hline $\mathrm{Et}_{\mathrm{sep}}$ & Separation efficiency & EFT & normal & 0.25 & & 1 & This study \\
\hline Yield $_{\text {biogas_CH4 }}$ & Biogas- $\mathrm{CH}_{4}$ yield & EFT & normal & 0.25 & & 1 & This study \\
\hline $\mathrm{f}_{\text {biogas_CH} 4}$ & Biogas composition & EFT & normal & 0.25 & & 1 & This study \\
\hline$f_{\text {Deg_vs }}$ & Degradation rates, in AD & EFT & normal & 0.25 & & 1 & This study \\
\hline If $_{\text {storage_dig_NH3 }}$ & $\mathrm{NH}_{3}$ increase factor, digestate stored & EFT & normal & 0.5 & & 1 & This study \\
\hline $\mathrm{Re}_{\text {storage_dig_CH4 }}$ & $\mathrm{CH}_{4}$ reduction factor, digestate stored & EFT & normal & 0.25 & & 1 & (Miranda et al., 2015) \\
\hline $\mathrm{EF}_{\mathrm{NDN} \_\mathrm{NH} 3}$ & $\mathrm{NH}_{3}$ EFs, NDN treatment & EFT & normal & 0.5 & & 1 & This study \\
\hline $\mathrm{EF}_{\mathrm{NDN} \_\mathrm{N} 2 \mathrm{O}}$ & $\mathrm{N}_{2} \mathrm{O}$ EFs, NDN treatment & EFT & normal & 0.5 & & 1 & This study \\
\hline
\end{tabular}




\section{Chapter 5}

\begin{tabular}{|c|c|c|c|c|c|c|c|}
\hline $\mathrm{EF}_{\mathrm{NDN} \_\mathrm{N} 2}$ & $\mathrm{~N}_{2} \mathrm{EFs}, \mathrm{NDN}$ treatment & EFT & normal & 0.25 & & 1 & This study \\
\hline $\mathrm{f}_{\text {incinerate_residue }}$ & Fractions of nutrients in ash, incinerate & EFT & normal & 0.25 & & 1 & This study \\
\hline $\mathrm{EF}_{\text {incinerate_NH3/N2O/NOx }}$ & EFs from incineration & EFT & normal & 0.25 & & 1 & This study \\
\hline $\mathrm{EF}_{\text {thermal-dry_NH3/N2O/NOx }} / \mathrm{N} 2$ & EFs from thermal-dry & EFT & normal & 0.5 & & 1 & This study \\
\hline $\mathrm{Re}_{\text {dry_scrubber_NH3 }}$ & $\mathrm{NH}_{3}$ reduction efficiency, air scrubber & EFT & normal & 0.1 & & 1 & (Ghaly \& Alhattab, 2013) \\
\hline If $_{\text {biodry_NH3 }}$ & $\mathrm{NH}_{3}$ increase factor, during bio-drying & EFT & normal & 0.5 & & 1 & This study \\
\hline If $_{\text {compost_NH3 }}$ & $\mathrm{NH}_{3}$ increase factor, composting & EFT & normal & 0.59 & & 1 & (Pardo et al., 2015) \\
\hline $\mathrm{Re}_{\text {compost_N2O }}$ & $\mathrm{N}_{2} \mathrm{O}$ reduction factor, composting & EFT & normal & 0.79 & & 1 & (Pardo et al., 2015) \\
\hline $\mathrm{Re}_{\text {compost_CH4 }}$ & $\mathrm{CH}_{4}$ reduction factor, composting & EFT & normal & 0.5 & & 1 & (Pardo et al., 2015) \\
\hline $\mathrm{f}_{\text {biochar_C\&N\&P }}$ & Nutrient fractions remained in biochar & EFT & normal & 0.25 & & 1 & This study \\
\hline $\mathrm{EF}_{\text {applic_slurry/solid/compost(etc.)_NH3 }}$ & $\mathrm{NH}_{3} \mathrm{EFs}$ for applied manure products & EFA & normal & 0.25 & & 0.8 & (Zhu et al., 2015) \\
\hline $\mathrm{EF}_{\text {graz_slurry_NH3 }}$ & $\mathrm{NH}_{3}$ EFs from excreta of gazing animal & EFA & normal & 0.25 & & 0.8 & (Zhu et al., 2015) \\
\hline $\mathrm{Re}_{\text {applic_LF/acid }}$ & $\begin{array}{l}\mathrm{NH}_{3} \text { reduction factors, applied (separated) liquid } \\
\text { fraction and acidified slurry }\end{array}$ & EFA & normal & 0.5 & & 1 & (Hou et al., 2015) \\
\hline $\mathrm{EF}_{\text {applic_slurry//compost(etc.)_NN2O }}$ & $\mathrm{N}_{2} \mathrm{O}$ EFs for applied manure products & EFA & Lognormal & & 0.28 & 0.5 & (Zhu et al., 2015) \\
\hline $\mathrm{Re}_{\text {applic_dig/sep.SF(etc.)_N2O }}$ & $\mathrm{N}_{2} \mathrm{O}$ reduction factors, applied treated manure & EFA & normal & 0.49 & & 1 & (Hou et al., 2015) \\
\hline $\mathrm{EF}_{\text {graz_slurry_N2O }}$ & $\mathrm{N}_{2} \mathrm{O}$ EFs from excreta of gazing animal & EFA & Lognormal & & 0.57 & 0.5 & (Zhu et al., 2015) \\
\hline
\end{tabular}

${ }^{a}$ The uncertainty analysis was performed according to the methodology described by Zhu et al. (2015) who analyzed the uncertainty of the MITERRA model for global animal production; the uncertainties (CV or SD) were also mainly derived from Zhu et al. (2015), and other meta-analysis studies (Hou et al., 2015; Miranda et al., 2015; Pardo et al., 2015).

${ }^{\mathrm{b}}$ LAD: livestock activity data (i.e. animal numbers); EXE: parameters used for calculating nutrient excretion; EFH: parameters (e.g. emission factors) used for calculating emissions from housing and manure storages; EFT: parameters used for calculating emissions during manure treatment; EFA: parameters used for calculating emissions during manure application to land; TAD: manure treatment activity data.

${ }^{\mathrm{c}}$ For these parameters, little information on uncertainties was available. We assigned the $\mathrm{CV}$ of these parameters using three categories: high uncertainty $(\mathrm{CV}=0.5)$, moderate uncertainty $(\mathrm{CV}=0.25)$ and low uncertainty $(\mathrm{CV}=0.1)$, following (Kros et al., 2012; Zhu et al., 2015). Low uncertainty was used for parameters derived from good-quality statistical databases; high uncertainty was used for parameters based on expert knowledge or derived from model estimates or limited published data. 


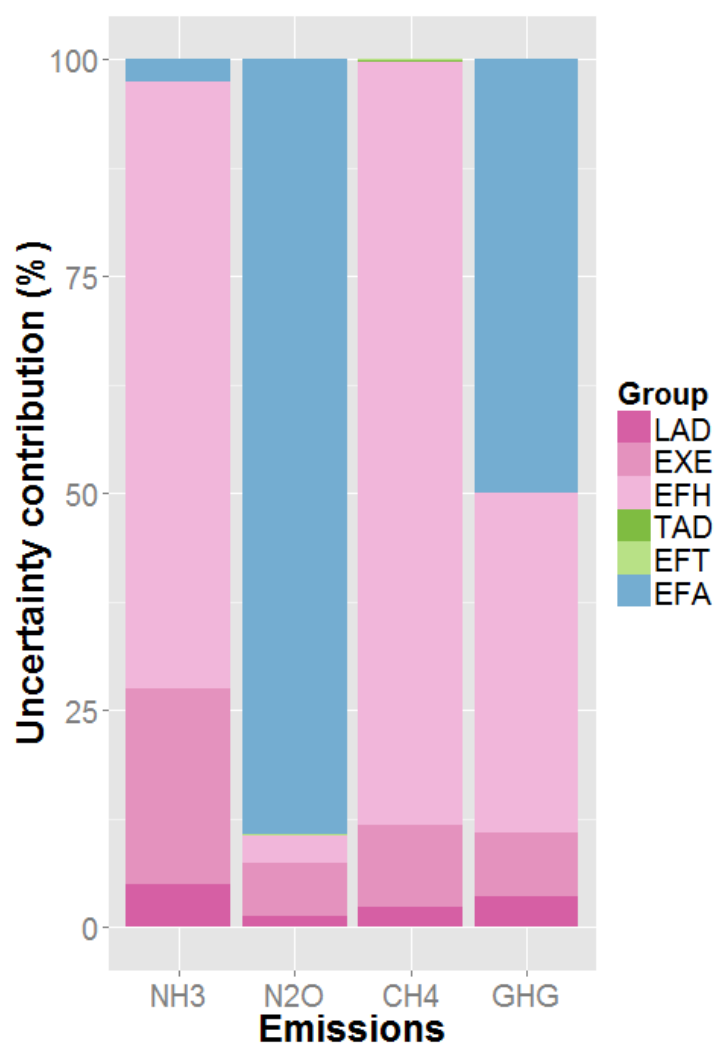

Figure S1. Uncertainty contribution of different groups of model inputs and parameters to the total emissions of $\mathrm{NH}_{3}, \mathrm{~N}_{2} \mathrm{O}, \mathrm{CH}_{4}$ and $\mathrm{GHG}$ from animal manure in EU-27 in 2010. (LAD: livestock activity data (i.e. animal numbers); EXE: parameters used for calculating nutrient excretion; EFH: parameters (e.g. EFs) used for calculating emissions from housing and manure storages; EFT: parameters used for calculating emissions during manure treatment; EFA: parameters used for calculating emissions during manure application to land; TAD: manure treatment activity data; see details in Table S4) 


\section{References}

Asman WAH, Klimont Z, Brink C (2011) A simplified model of nitrogen flows from manure management. IIASA Interim Report IR-11-030. International Institute for Applied Systems Analysis (IIASA), Laxenburg, Austria.

Azuara M, Kersten SRA, Kootstra AMJ (2013) Recycling phosphorus by fast pyrolysis of pig manure: Concentration and extraction of phosphorus combined with formation of value-added pyrolysis products. Biomass and Bioenergy, 49, 171-180.

Baniasadi M, Tugnoli A, Conti R, Torri C, Fabbri D, Cozzani V (2016) Waste to energy valorization of poultry litter by slow pyrolysis. Renewable Energy, 90, 458-468.

Beline F, Daumer ML, Loyon L, Pourcher AM, Dabert P, Guiziou F, Peu P (2008) The efficiency of biological aerobic treatment of piggery wastewater to control nitrogen, phosphorus, pathogen and gas emissions. Water Sci Technol, 57, 1909-1914.

Béline F, Martinez J (2002) Nitrogen transformations during biological aerobic treatment of pig slurry: effect of intermittent aeration on nitrous oxide emissions. Bioresource Technology, 83, 225-228.

Bernet N, Béline F (2009) Challenges and innovations on biological treatment of livestock effluents. Bioresource technology, 100, 5431-6.

Billen P, Costa J, Van der Aa L, Van Caneghem J, Vandecasteele C (2015) Electricity from poultry manure: a cleaner alternative to direct land application. Journal of Cleaner Production, 96, 467475 .

Bittman S, Dedina M, Howard C, Oenema O, Sutton M (2014) Options for Ammonia Mitigation: Guidance from the UNECE Task Force on Reactive Nitrogen. Centre for Ecology and Hydrology, Edinburgh, UK.

Brassard P, Palacios JH, Godbout S, Bussières D, Lagacé R, Larouche J-P, Pelletier F (2014) Comparison of the gaseous and particulate matter emissions from the combustion of agricultural and forest biomasses. Bioresource Technology, 155, 300-306.

Campos E, Almirall M, Mtnez-Almela J, Palatsi J, Flotats X (2008) Feasibility study of the anaerobic digestion of dewatered pig slurry by means of polyacrylamide. Bioresource technology, 99, 38795.

Cantrell KB, Hunt PG, Uchimiya M, Novak JM, Ro KS (2012) Impact of pyrolysis temperature and manure source on physicochemical characteristics of biochar. Bioresource technology, 107, 41928.

Cayuela ML, van Zwieten L, Singh BP, Jeffery S, Roig A, Sánchez-Monedero M a. (2014) Biochar's role in mitigating soil nitrous oxide emissions: A review and meta-analysis. Agriculture, Ecosystems \& Environment, 191, 5-16.

Chadwick D, Sommer S, Thorman R, Fangueiro D, Cardenas L, Amon B, Misselbrook T (2011) Manure management: Implications for greenhouse gas emissions. Animal Feed Science and Technology, 166-167, 514-531.

Christel W, Bruun S, Magid J, Jensen LS (2014) Phosphorus availability from the solid fraction of pig slurry is altered by composting or thermal treatment. Bioresource Technology, 169, 543-551.

Clemens J, Trimborn M, Weiland P, Amon B (2006) Mitigation of greenhouse gas emissions by anaerobic digestion of cattle slurry. Agriculture, Ecosystems \& Environment, 112, 171-177.

Converse J, Karthikeyan K (2004) Nutrient and solids separation of flushed dairy manure by gravity settling. Applied Engineering in Agriculture, 20, 503-507.

CSIRO 2007. Nutrient Requirements of Domesticated Ruminants. CSIRO Publishing: Melbourne, Australia.

Danish Agrifish Agency Aftale om Grøn Vækst. Danish Ministry of Food, Agriculture and Fisheries. Copenhagen, Denmark. http://mst.dk/virksomhed-myndighed/landbrug/politiske-aftaler/groenvaekst/. 
Edwards J, Othman M, Burn S (2015) A review of policy drivers and barriers for the use of anaerobic digestion in Europe, the United States and Australia. Renewable and Sustainable Energy Reviews, $52,815-828$.

EEA (2014a) European Union emission inventory report 1990-2012 under the UNECE Convention on Long-range Transboundary Air Pollution (LRTAP). $130 \mathrm{pp.}$

EEA (2014b) Annual European Union greenhouse gas inventory 1990-2013 and inventory report 2015, submission to the UNFCCC. http://unfccc.int/national_reports/items/1408.php.

European Commission (2009) Directive 2009/28/ EC of the European Parliament and of the Council on the promotion of the use of energy from renewable sources and amending and subsequently repealing Directives 2001/77/EC and 2003/30/EC. Official Journal of the European Union, L 140/16, 16-62.

Eurostat http://ec.europa.eu/eurostat/data/database (accessed February 10, 2016).

Fangueiro D, Senbayran M, Trindade H, Chadwick D (2008) Cattle slurry treatment by screw press separation and chemically enhanced settling: effect on greenhouse gas emissions after land spreading and grass yield. Bioresource technology, 99, 7132-42.

Fangueiro D, Ribeiro H, Vasconcelos E, Coutinho J, Cabral F (2009) Treatment by acidification followed by solid-liquid separation affects slurry and slurry fractions composition and their potential of N mineralization. Bioresource technology, 100, 4914-7.

Fangueiro D, Hjorth M, Gioelli F (2015a) Acidification of animal slurry- a review. Journal of Environmental Management, 149, 46-56.

Fangueiro D, Surgy S, Fraga I, Cabral F, Coutinho J (2015b) Band application of treated cattle slurry as an alternative to slurry injection: Implications for gaseous emissions, soil quality, and plant growth. Agriculture, Ecosystems \& Environment, 211, 102-111.

Fernandez-Lopez M, Puig-Gamero M, Lopez-Gonzalez D, Avalos-Ramirez A, Valverde J, SanchezSilva L (2015) Life cycle assessment of swine and dairy manure: Pyrolysis and combustion processes. Bioresource Technology, 182, 184-192.

Foged HL, Flotats X, Blasi AB, Palatsi J, Magri A, Schelde KM (2011) Inventory of manure processing activities in Europe. Technical Report No. I concerning "Manure Processing Activities in Europe" to the European Commission, Directorate-General Environment. 138 pp.

Galloway JN, Dentener FJ, Capone DG et al. (2004) Nitrogen Cycles: Past, Present, and Future. Biogeochemistry, 70, 153-226.

Ghaly AE, Alhattab M (2013) Drying Poultry Manure for Pollution Potential Reduction and Production of Organic Fertilizer. American Journal of Environmental Sciences, 9, 88-102.

Gioelli F, Dinuccio E, Cuk D, Rollè L, Balsari P (2016) Acidification with sulfur of the separated solid fraction of raw and co-digested pig slurry: Effect on greenhouse gas and ammonia emissions during storage. Animal Production Science, 56, 343-349.

Hamelin L, Wesnæs M, Wenzel H, Petersen BM (2011) Environmental consequences of future biogas technologies based on separated slurry. Environmental science \& technology, 45, 5869-77.

Hamelin L, Naroznova I, Wenzel H (2014) Environmental consequences of different carbon alternatives for increased manure-based biogas. Applied Energy, 114, 774-782.

Van der Heyden C, Demeyer P, Volcke EIP (2015) Mitigating emissions from pig and poultry housing facilities through air scrubbers and biofilters: State-of-the-art and perspectives. Biosystems Engineering, 134, 74-93.

Hjorth M, Christensen K V., Christensen ML, Sommer SG (2010) Solid-liquid separation of animal slurry in theory and practice. A review. Agronomy for Sustainable Development, 30, 153-180.

Hou Y, Velthof GL, Oenema O (2015) Mitigation of ammonia, nitrous oxide and methane emissions from manure management chains: a meta-analysis and integrated assessment. Global Change Biology, 21, 1293-1312.

Hou Y, Bai Z, Lesschen JP et al. (2016) Feed use and nitrogen excretion of livestock in EU-27. 


\section{Chapter 5}

Agriculture, Ecosystems and Environment, 218, 232-244.

Intergovernmental Panel on Climate Change (IPCC). (2006) Chapter 10. Emissions from livestock and manure management. In: 2006 IPCC guidelines for national greenhouse gas inventories. Volume 4: Agriculture, forestry and other land use. 10.1-10.87 pp.

Kai P, Pedersen P, Jensen JE, Hansen MN, Sommer SG (2008) A whole-farm assessment of the efficacy of slurry acidification in reducing ammonia emissions. European Journal of Agronomy, $28,148-154$.

Kim S-S, Agblevor F a., Lim J (2009) Fast pyrolysis of chicken litter and turkey litter in a fluidized bed reactor. Journal of Industrial and Engineering Chemistry, 15, 247-252.

Klimont Z, Brink C (2004) Modelling of Emissions of Air Pollutants and Greenhouse Gases from Agricultural Sources in Europe. International Institute for Applied Systems Analysis (IIASA), Laxenburg, Austria.

Koirala K, Ndegwa PM, Joo HS, Frear C, Stockle CO, Harrison JH, Velsen V (2013) Impact of Anaerobic Digestion of Liquid Dairy Manure on Ammonia Volatilization Process. American Society of Agricultural and Biological Engineers, 56, 1959-1966.

Kookana RS, Sarmah AK, Zwieten L Van, Krull E (2011) Biochar Application to Soil: Agronomic and Environmental Benefits and Unintended Consequences, 1st edn, Vol. 112. Elsevier Inc., 103-143 pp.

Kros J, Heuvelink GBM, Reinds GJ, Lesschen JP, Ioannidi V, De Vries W (2012) Uncertainties in model predictions of nitrogen fluxes from agro-ecosystems in Europe. Biogeosciences, 9, 45734588.

Lesschen JP, van den Berg M, Westhoek HJ, Witzke HP, Oenema O (2011) Greenhouse gas emission profiles of European livestock sectors. Animal Feed Science and Technology, 166-167, 16-28.

Li L, Takarada T (2013) Conversion of nitrogen compounds and tars obtained from pre-composted pig manure pyrolysis, over nickel loaded brown coal char. Biomass and Bioenergy, 56, 456-463.

Loyon L, Guiziou F, Beline F, Peu P (2007) Gaseous Emissions $\left(\mathrm{NH}_{3}, \mathrm{~N}_{2} \mathrm{O}, \mathrm{CH}_{4}\right.$ and $\left.\mathrm{CO}_{2}\right)$ from the aerobic treatment of piggery slurry-Comparison with a conventional storage system. Biosystems Engineering, 97, 472-480.

Maurer C, Müller J (2012) Ammonia $\left(\mathrm{NH}_{3}\right)$ emissions during drying of untreated and dewatered biogas digestate in a hybrid waste-heat/solar dryer. Engineering in Life Sciences, 12, 321-326.

Melse RW, Timmerman M (2009) Sustainable intensive livestock production demands manure and exhaust air treatment technologies. Bioresource technology, 100, 5506-11.

Melse RW, Verdoes N (2005) Evaluation of Four Farm-scale Systems for the Treatment of Liquid Pig Manure. Biosystems Engineering, 92, 47-57.

Miranda ND, Tuomisto HL, McCulloch MD (2015) Meta-analysis of GHG emissions from anaerobic digestion processes in dairy farms. Environmental Science \& Technology, 49, 5211-5219.

Møller H, Lund I, Sommer S (2000) Solid-liquid separation of livestock slurry: efficiency and cost. Bioresource Technology, 74, 223-229.

Møller HB, Sommer SG, Ahring BK (2002) Separation efficiency and particle size distribution in relation to manure type and storage conditions. Bioresource Technology, 85, 189-96.

Møller HB, Sommer SG, Ahring BK (2004a) Methane productivity of manure, straw and solid fractions of manure. Biomass and Bioenergy, 26, 485-495.

Møller H, Sommer S, Ahring B (2004b) Biological degradation and greenhouse gas emissions during pre-storage of liquid animal manure. Journal of Environmental Quality, 27-36.

Møller HB, Jensen HS, Tobiasen L, Hansen MN (2007b) Heavy metal and phosphorus content of fractions from manure treatment and incineration. Environmental Technology, 28, 1403-18.

Møller H, Hansen J, Sørensen C (2007a) Nutrient recovery by solid-liquid separation and methane productivity of solids. Transactions of the ASABE, 50, 193-200. 
Oenema O, Wrage N, Velthof GL, Groenigen JW, Dolfing J, Kuikman PJ (2005) Trends in Global Nitrous Oxide Emissions from Animal Production Systems. Nutrient Cycling in Agroecosystems, $72,51-65$.

Oenema O, Oudendag D, Velthof GL (2007) Nutrient losses from manure management in the European Union. Livestock Science, 112, 261-272.

Oenema O, Witzke HP, Klimont Z, Lesschen JP, Velthof GL (2009) Integrated assessment of promising measures to decrease nitrogen losses from agriculture in EU-27. Agriculture, Ecosystems \& Environment, 133, 280-288.

Oenema O, Bleeker A, Braathen NA et al. (2011) Nitrogen in current European policies. In: The European nitrogen assess ment (eds Sutton MA, Howard CM, Erisman JW, Billen G, Bleeker A, Grennfelt P, Grinsven H van, Grizzetti B), pp. 62-81. Cambridge University Press, Cambridge, UK.

Oenema O, Ju X, de Klein C et al. (2014) Reducing nitrous oxide emissions from the global food system. Current Opinion in Environmental Sustainability, 9-10, 55-64.

Ottosen LDM, Poulsen H V., Nielsen DA, Finster K, Nielsen LP, Revsbech NP (2009) Observations on microbial activity in acidified pig slurry. Biosystems Engineering, 102, 291-297.

Pantelopoulos A, Magid J, Jensen LS (2016) Thermal drying of the solid fraction from biogas digestate: Effects of acidification, temperature and ventilation on nitrogen content. Waste Management, 48, 218-226.

Pardo G, Moral R, Aguilera E, del Prado A (2015) Gaseous emissions from management of solid waste: a systematic review. Global Change Biology, 21, 1313-1327.

Petersen S, Sommer S, Beline F et al. (2007) Recycling of livestock manure in a whole-farm perspective. Livestock Science, 112, 180-191.

Petersen SO, Andersen AJ, Eriksen J (2012) Effects of cattle slurry acidification on ammonia and methane evolution during storage. Journal of environmental quality, 41, 88-94.

Petersen SO, Hutchings NJ, Hafner SD, Sommer SG, Hjorth M, Jonassen KEN (2016) Ammonia abatement by slurry acidification: A pilot-scale study of three finishing pig production periods. Agriculture, Ecosystems \& Environment, 216, 258-268.

Popovic O, Hjorth M, Jensen LS (2012) Phosphorus, copper and zinc in solid and liquid fractions from full-scale and laboratory-separated pig slurry. Environmental technology, 33, 2119-31.

Ramirez AA, Godbout S, Leveillee F, Zegan D, Larouche JP (2012) Effect of temperature and air flow rate on carbon and nitrogen compounds changes during the biodrying of swine manure in order to produce combustible biomasses. Journal of Chemical Technology and Biotechnology, 87, 831-836.

Regueiro I, Coutinho J, Gioelli F, Balsari P, Dinuccio E, Fangueiro D (2016) Acidification of raw and co-digested pig slurries with alum before mechanical separation reduces gaseous emission during storage of solid and liquid fractions. Agriculture, Ecosystems \& Environment, 227, 42-51.

Riaño B, García-González MC (2014) On-farm treatment of swine manure based on solid-liquid separation and biological nitrification-denitrification of the liquid fraction. Journal of Environmental Management, 132, 87-93.

Rico JL, García H, Rico C, Tejero I (2007) Characterisation of solid and liquid fractions of dairy manure with regard to their component distribution and methane production. Bioresource Technology, 98, 971-9.

Ro KS, Cantrell KB, Hunt PG (2010) High-Temperature Pyrolysis of Blended Animal Manures for Producing Renewable Energy and Value-Added Biochar. Industrial \& Engineering Chemistry Research, 49, 10125-10131.

Rodhe L, Karlsson S (2002) Ammonia Emissions from Broiler Manure - Influence of Storage and Spreading Method. Biosystems Engineering, 82, 455-462.

Sadaka S, Ahn H (2012) Evaluation of a Biodrying Process for Beef, Swine, and Poultry Manures 


\section{Chapter 5}

Mixed Separately with Corn Stover. Applied Engineering in Agriculture, 28, 457-463.

Sistani KR, Rowe DE, Miles DM, May JD (2001) Effects of drying method and rearing temperature on broiler manure nutrient content. Communications in Soil Science and Plant Analysis, 32, 2307-2316.

Sommer SG (1997) Ammonia volatilization from farm tanks containing anaerobically digested animal slurry. Atmospheric Environment, 31, 863-868.

Sommer SG, Olesen JE, Petersen SO, Weisbjerg MR, Valli L, Rohde L, Béline F (2009) Regionspecific assessment of greenhouse gas mitigation with different manure management strategies in four agroecological zones. Global Change Biology, 15, 2825-2837.

Sommer SG, Christensen ML, Schmidt T, Jensen LS (2013) Animal Manure Recycling: Treatment and Management. $382 \mathrm{pp}$.

Song W, Guo M (2012) Quality variations of poultry litter biochar generated at different pyrolysis temperatures. Journal of Analytical and Applied Pyrolysis, 94, 138-145.

Sørensen P, Eriksen J (2009) Effects of slurry acidification with sulphuric acid combined with aeration on the turnover and plant availability of nitrogen. Agriculture, Ecosystems \& Environment, 131, 240-246.

Steinfeld H, Gerber P, Wassenaar T, Castel V, Roslaes M, De Haan C (2006) Livestock's long shadow. environmental issues and options. FAO report, Rome, Italy. 390 pp.

Thangarajan R, Bolan NS, Tian G, Naidu R, Kunhikrishnan A (2013) Role of organic amendment application on greenhouse gas emission from soil. The Science of the total environment, 465, 7296.

Troy SM, Nolan T, Leahy JJ, Lawlor PG, Healy MG, Kwapinski W (2013) Effect of sawdust addition and composting of feedstock on renewable energy and biochar production from pyrolysis of anaerobically digested pig manure. Biomass and Bioenergy, 49, 1-9.

UNFCCC http://unfccc.int/national_reports/annex_i_ghg_inventories/national_inventories_ submissions/items/8812.php (accessed October 1, 2015).

UNFCCC Kyoto Protocol to the United Nations Framework Convention on Climate Change. http://unfccc.int/kyoto_protocol/items/2830.php (accessed October 1, 2015).

van Dijk KC, Lesschen JP, Oenema O (2015) Phosphorus flows and balances of the European Union Member States. Science of The Total Environment, 542, 1078-1093.

Velthof GL, Oudendag D, Witzke HP, Asman W a H, Klimont Z, Oenema O (2009) Integrated assessment of nitrogen losses from agriculture in EU-27 using MITERRA-EUROPE. Journal of environmental quality, 38, 402-17.

Weiss F, Leip A (2012) Greenhouse gas emissions from the EU livestock sector: A life cycle assessment carried out with the CAPRI model. Agriculture, Ecosystems \& Environment, 149, $124-134$.

Willers HC, Derikx PJL, Have PJW Ten, Vijn TK (1996) Emission of Ammonia and Nitrous Oxide from Aerobic Treatment of Veal Calf Slurry. Journal of Agricultural Engineering Research, 63, 345-352.

Wnetrzak R, Kwapinski W, Peters K, Sommer SG, Jensen LS, Leahy JJ (2013) The influence of the pig manure separation system on the energy production potentials. Bioresource technology, 136, $502-8$.

Zhu B, Kros J, Lesschen JP, Staritsky IG, de Vries W (2015) Assessment of uncertainties in greenhouse gas emission profiles of livestock sectors in Africa, Latin America and Europe. Regional Environmental Change, 16, 1571-1582. 


\section{CHAPTER 6}

\section{Stakeholder perceptions of manure treatment technologies in Denmark, Italy, the Netherlands and Spain}




\section{Chapter 6}

\section{Abstract:}

Animal manures are valuable sources of plant nutrients, bioenergy and organic matter for enhancing soil quality, but are also associated with a range of environmental issues. Manure treatment technologies have been developed in Europe to better use animal manures and to reduce their environmental impact, but the adoption of these technologies in practice is regionally diverse and still limited. Also, little is known about the opinions of stakeholders towards manure treatment. This study aimed to identify stakeholder perceptions of (1) which factors can facilitate and hinder the implementation in practice, (2) which technologies have the most potential for successful adoption, and (3) how farm characteristics and scale of treatment operations affect priorities for technology adoption. This analysis used data from a survey of various stakeholders engaged in manure treatment in four European countries (Denmark, Italy, the Netherlands and Spain) that have large areas of high animal density, but diverse socio-economic, political and environmental conditions. Pressure from governmental regulations was perceived as a key factor that stimulated manure treatment in all four countries (70\% of respondents). Processing manure to produce bioenergy was considered important in Denmark and Italy, but less important in Spain and the Netherlands. The major barriers to technology adoption were related to economic factors (lack of investment capital, high processing cost and a long payback time; 45-60\% of respondents), while there was relatively little concern regarding transport, noise burden and health risk. Slurry separation and anaerobic digestion were perceived to have the greatest potential for a common adoption in practice. Other preferred technologies were more country-specific (e.g. acidification in Denmark, composting in Spain, and drying and reverse osmosis in Netherlands). Farm characteristics and scale of operation were identified as important factors for technology adoption. The implementation of manure treatment in practice was facilitated by the pressure from environmental regulations, and was hindered by financial barriers. Manure treatment will therefore remain a regional activity. Policy measures and outreach strategies to alleviate the main barriers and to encourage the adoption of manure treatment are suggested. 


\subsection{Introduction}

Animal manures are valuable sources of plant nutrients, soil organic matter and bioenergy. However, following the introduction of relatively cheap inorganic fertilizers from the 1950s onwards, animal manures were increasingly considered as a waste, especially in affluent countries (e.g., in Europe and North America; Van der Meer, 1987). Recently, inappropriate use and inefficient recycling of animal manures, particularly in regions with high animal density, have exerted a series of negative impacts on the environment, e.g. eutrophication of ecosystems, soil acidification and global warming (Steinfeld et al., 2006). In Europe, the livestock sector is currently responsible for about $80 \%$ of total European ammonia $\left(\mathrm{NH}_{3}\right)$ emissions, $10-17 \%$ of greenhouse gas (GHG) emissions, $40-50 \%$ of diffuse nitrogen $(\mathrm{N})$ and $70 \%$ of inorganic phosphorus (P) losses to inland and coastal water (Leip et al., 2015). In response, a series of governmental policies have been implemented by the European Union (EU) and some of its Member States to improve the utilization of manure nutrients in agriculture and therefore decrease their environment impact (Oenema et al., 2011). These policies have contributed towards the development of manure treatment technologies, which are important for achieving cleaner production in livestock husbandry.

Historically, manure has always been treated and used for various purposes. Attempts to produce biogas from manure date back to the 10th century B.C. (Bond \& Templeton, 2011). Efforts to recover specific nutrients or to increase the agronomic value of manure date from the second half of the $20^{\text {th }}$ century (Van der Meer, 1987). Manure has been dried and used as fuel and building material probably as long as there has been animal agriculture. A wide range of new manure treatment technologies have been developed and are now available in Europe. These technologies are considered to be of great importance for the development of sustainable agricultural systems and societies (Foged et al., 2011a; Sommer et al., 2013). Several technologies (e.g. slurry acidification, anaerobic digestion) are used to decrease ammonia and/or GHG emissions from animal manure, and thereby decrease the risk of climate change and acidification of ecosystems. Technologies have been developed to produce renewable energy from manure, for instance, through anaerobic digestion (i.e. biogas production) and incineration (Billen et al., 2015; Kimming et al., 2015). Manure-based bioenergy production decreases $\mathrm{CO}_{2}$ emissions by substituting fossil fuel for power and electricity production, and therefore is a crucial contributor to the development of bioeconomy. Other technologies (e.g. solid-liquid separation, drying, composting, reverse 


\section{Chapter 6}

osmosis) have been developed to improve manure handling and transportation characteristics (Sommer et al., 2013). In addition, various manure-based products resulting from these treatment technologies provide opportunities for better nutrient management in agriculture. These products may reduce unnecessary mineral fertilizer use and so the associated resource use and environmental pollution from fertilizer production (Sommer et al., 2013).

Implementation of manure treatment technologies in practice is however limited and regionally scattered in the EU. Less than $10 \%$ of the total animal manure production (excluding excreta of grazing animals) was processed in the EU-27 in 2010, with large variations between countries (Foged et al., 2011a). The extent to which treatment technology advances in a country can be influenced by governmental policies and the perceptions of key stakeholders. Environmental policies and legislations vary between EU countries. Although EU Directives set the framework in which all Member States must create legislations directed at civilians/industries to attain the EU-scale objectives, Member States have some flexibility to implement these Directives (Oenema et al., 2011). For example, there is flexibility in the design of national action programs and the use of mitigation measures and techniques in the Nitrates Directive (1991/676/EC) and National Emission Ceiling Directive (2001/81/EC). In addition, differences in farming systems and environmental conditions in the EU, combined with the complexity of manure management and nutrient recycling, can also affect the adoption of treatment technologies (Sommer et al., 2013). To facilitate the proper development of manure treatment technology, there is a need to improve understanding of the reasons for the limited and scattered implementation of these treatment technologies in practice in the EU, especially in regions with high animal density.

While extensive research has been conducted to evaluate the technical, environmental and economic performance of manure treatment technologies in EU, stakeholder opinions regarding the factors influencing manure treatment in practice have not received significant consideration. The diffusion and exploitation of cleaner technologies relies on a combination of factors including governmental policies, financial incentives, technical and service support, and social acceptance (Montalvo, 2008). A better understanding of needs and perceptions of stakeholders from both the supply and demand side is essential to allow for successful innovations for sustainable production and consumption to be shared, spread and scaled up (Blok et al., 2015). The development of manure treatment involves stakeholders across government, industry, academia, extension services and agricultural production sectors. 
Integration between policy fields, expert bodies and types of expertise is increasingly required in framing and assessing these EU environmental policies (Kowarsch, 2015). Stakeholders from different sectors may have diverse opinions regarding the objectives of a policy measure as well as on the relevant actions needed to achieve it (Petit \& van der Werf, 2003; Van Dam \& Junginger, 2011). Policy makers and researchers generally have a broad picture of environmental issues and manure management at regional and national scales. In contrast, the experience of individual farmers is more tied to a particular farm environment, and their decisions are shaped mostly by local socio-economic conditions (Ingram, 2008; Asai et al., 2014). Agricultural advisors have an fair understanding of a group of farmers and their farms through regular contact, enabling them to develop a geographically broad impression of the farming community (Ingram, 2008). Increased understanding among stakeholders involved in the system can help to overcome barriers to the adoption and exploitation of manure treatment technologies.

Few studies have been conducted to investigate stakeholder perceptions of factors influencing the adoption of manure treatment technologies. Examples include studies focusing on composting (Viaene et al., 2016), slurry separation (Gebrezgabher et al., 2015) and anaerobic digestion (Hoppe \& Sanders, 2014; Dahlin et al., 2015) in several EU countries. A study in the Netherlands reported that farmer attitudes toward the various properties of manure separation technology were important determinants of adoption. Farmer attitudes were positive towards the agronomic attributes of separation such as the ability to use nutrients (e.g. $\mathrm{N}$ and $\mathrm{P}$ ) in manure optimally, but the economic benefits were generally not appreciated (Gebrezgabher et al., 2015). Barriers to on-farm composting in Belgium were studied based on interviews with stakeholders, which found that strict regulation, considerable financial investment, and lack of experience and knowledge were hindering on-farm composting (Viaene et al., 2016). An analysis of stakeholder perceptions in the biogas production chain in several EU countries indicated that biogas producers and digestate suppliers face many risks and challenges, primarily linked to high financial cost (and sometimes little incentives), legal constraints for operation and market barriers to digestate application (Hoppe \& Sanders, 2014; Dahlin et al., 2015). These studies have illustrated that the adoption of manure treatment technology is likely to be affected by a wide range of diverse socio-political, environmental and agronomic factors. There is a need for better understanding of stakeholder perceptions of factors that currently influence manure treatment and also their perspectives regarding successful adoption of these technologies in future. 


\section{Chapter 6}

This study aimed to provide empirical insights into: (1) what stakeholders perceive as important to facilitate or hinder the implementation of manure treatment in practice, (2) stakeholder views of the technologies that have the most potential for successful adoption, and (3) how the preference of technologies with the most potential differs between farm types, farm sizes, and scale of treatment operations. To achieve these objectives, a survey of stakeholders from various groups was conducted in four EU countries: Denmark, Italy, the Netherlands and Spain. All selected countries have large areas of high animal density, but diverse political, farming and environmental contexts.

\subsection{Methods}

This section includes a description of the countries surveyed (Section 6.2.1), stakeholder categories (Section 6.2.2), the questionnaire structure (Section 6.2.3) and the methods regarding data collection and analysis (Section 6.2.4).

\subsubsection{Country selection and context}

Denmark (DK), Italy (IT), the Netherlands (NL) and Spain (ES) were selected to represent European countries that have highly-intensive animal production, and as a result, large pressure for manure handling and management (Figure 6-1). Average livestock densities are 1.9 and 3.6 livestock units (LU) per ha of utilized agricultural area in DK and NL, respectively (compared to the EU-27 average of $0.8 \mathrm{LU} \mathrm{ha}^{-1}$ ). In the north of IT (e.g. Lombardy and Veneto regions) and in some regions of ES (e.g. Catalonia and Murcia regions) livestock densities are also higher than $1.5 \mathrm{LU} \mathrm{ha}^{-1}$ (Figure 6-1).

These four countries were also selected because they vary in governmental policies, manure management systems and environmental conditions (Table 6-1). All four countries need to comply with the Nitrates Directive, which aims to protect water quality by promoting good farming practices and preventing the pollution of groundwater and surface waters by nitrate from agricultural sources (including animal manure). The implementation of the Nitrates Directive has had a great influence on manure management (Velthof et al., 2014). The whole territories of DK and NL have been designated as the so-called "Nitrate Vulnerable Zones" (NVZs), while the NVZs cover approximately $21 \%$ of total agricultural area in ES and $32 \%$ in Italy. Derogations have been granted for specific regions/farms in DK, IT and NL, which allow them to go beyond the limit of $170 \mathrm{~kg} \mathrm{~N} \mathrm{ha}^{-1}$ of manure application, while there is no 
derogation in ES. Renewable energy action plans differ between these countries, e.g. the use of animal manures for renewable energy production (Table 6-1). Soil organic matter is key to soil quality and productivity, and plays a major role in modifying chemical, microbiological and physical properties in ways that improve soil fertility. Mean organic carbon contents in the top soils are $<15 \mathrm{~g} \mathrm{C} \mathrm{kg}^{-1}$ in most regions of ES, while $>30 \mathrm{~g} \mathrm{C} \mathrm{kg}^{-1}$ on average in $\mathrm{NL}$ (Reijneveld et al., 2009; de Brogniez et al., 2015). The organic carbon content of the soil may affect decisions about the most suitable use of manure as a source of organic matter to improve soil quality (Diacono \& Montemurro, 2010). In DK and NL, manure management systems of dairy cattle are dominantly slurry-based, in contrast to the large fraction of solidbased systems in ES and IT (Table 6-1).

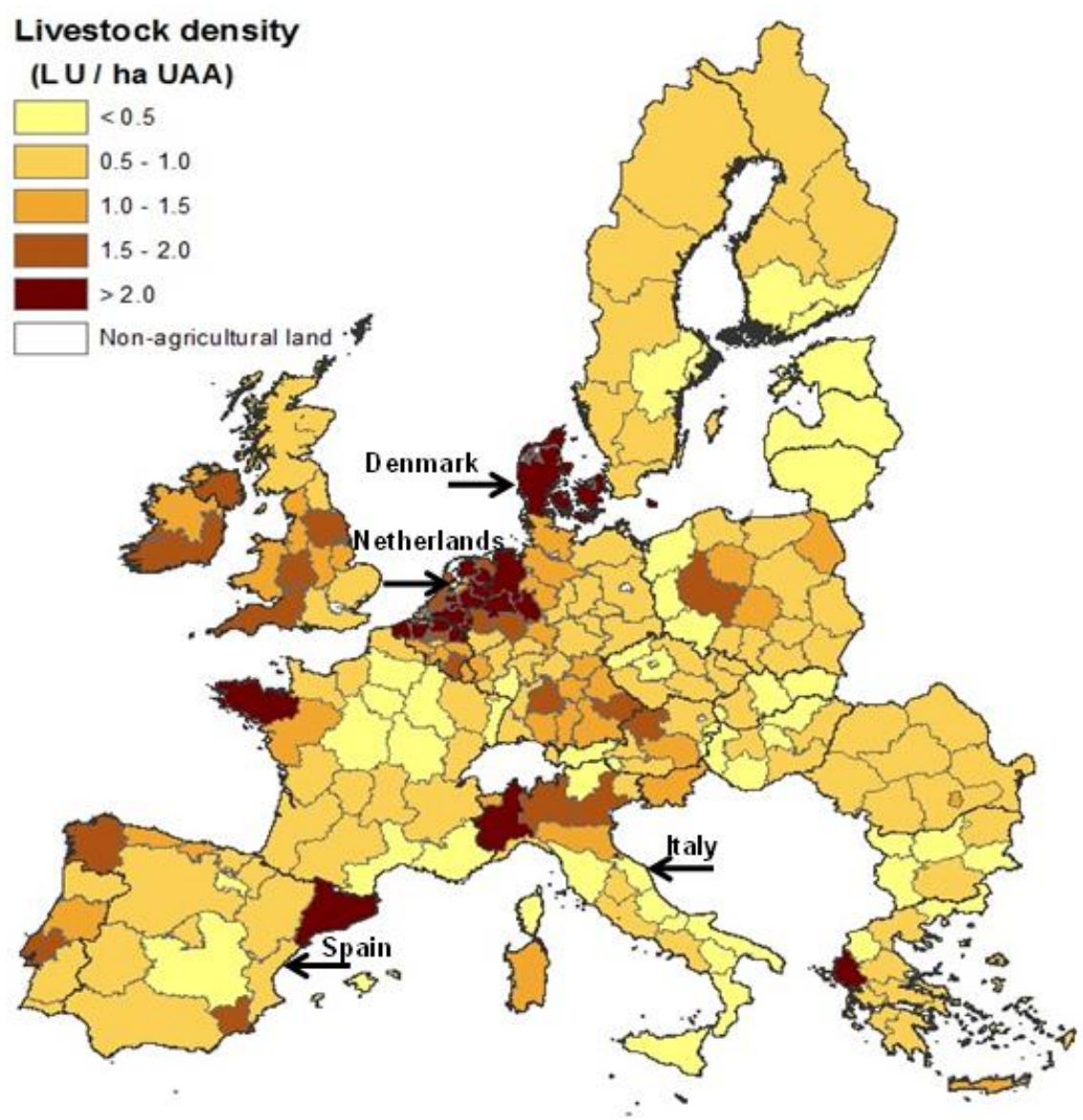

Figure 6-1. Livestock density in the EU-27, expressed in livestock units (LU) per ha utilized agricultural area (UAA). Data were from Eurostat (2010) for the year 2010. 
Table 6-1. A comparison of political and agri-environmental characteristics selected for the four European countries.

\begin{tabular}{|c|c|c|c|c|}
\hline & DK & NL & ES & IT \\
\hline \multicolumn{5}{|l|}{ Policies } \\
\hline \multicolumn{5}{|l|}{-Nitrates Directive } \\
\hline NVZs (\% total agricultural area) & 100 & 100 & 21 & 32 \\
\hline Derogation granted & Yes & Yes & No & Yes \\
\hline \multicolumn{5}{|l|}{-Renewable Energy (RE) Directive ${ }^{a}$} \\
\hline RE from manure in 2006 (ktoe ,kilotonne of oil equivalent) & $\sim 70$ & 0 & $\sim 1.6$ & n.a. \\
\hline Estimates in 2020 (ktoe) & $\sim 145$ & $\sim 98$ & $\sim 143$ & n.a. \\
\hline \multicolumn{5}{|l|}{ Agri-environmental conditions } \\
\hline -Average soil organic carbon in top soils $\left(\mathrm{g} \mathrm{kg}^{-1}\right)^{\mathrm{b}}$ & $20-30$ & $30-40$ & $<15$ & $15-20$ \\
\hline \multicolumn{5}{|l|}{-Manure management systems ( $\%$ of manure $\mathrm{N}$ from housing) ${ }^{\mathrm{c}}$} \\
\hline Dairy cow & $92 \%$ (slurry) & $99 \%$ (slurry) & $70 \%$ (solid) & $60 \%$ (solid) \\
\hline Other cattle & $60 \%$ (solid) & $83 \%$ (slurry) & $99 \%$ (solid) & $60 \%$ (slurry) \\
\hline Pigs & $95 \%$ (slurry) & $99 \%$ (slurry) & $90 \%$ (slurry) & $99 \%$ (slurry) \\
\hline
\end{tabular}

\subsubsection{Stakeholder groups}

Six stakeholder groups with expertise in the domain of manure treatment were chosen for this study: (i) livestock farmers; (ii) members of the board of farmers' organizations; (iii) agricultural advisors and consultants; (iv) developers and users of treatment technologies from industry (also including contractors with manure treatment facilities); (v) employees of public authorities (working on the development and control of agri-environmental policies); and (vi) researchers from academic institutions (with expertise in animal manure treatment) (Table 6-2).

\subsubsection{Questionnaire design}

The survey consisted of 62 questions divided into five sections. Section 1 dealt with respondents' experience in manure treatment. Section 2 related to opinions on factors that stimulate and hinder the implementation of manure treatment in practice. The selection of these factors (presented in the questionnaire) was based on peer-reviewed studies (e.g., Gebrezgabher et al., 2015; Hoppe and Sanders, 2014; Montalvo, 2008) and views of experts (including the authors) in the research of farm-based studies in the surveyed countries. Section 3 aimed to investigate stakeholder opinions about the technologies that have the most potential for successful adoption. Eight common treatment technologies were listed in the questionnaire: solid-liquid separation, acidification, anaerobic digestion, biological nitrogen removal, composting, drying, combustion/ incineration, and membrane filtration/ reverse osmosis (Foged et al., 2011a). For each technology there were four follow-up questions to 
investigate why, how and where the selected technologies had the greatest adoption potential (considering farm type, farm size and scale of operation, and the benefits of each technology). Section 4 collected demographic information, including employment categories (to distinguish between stakeholder groups) and farm characteristics (in the case of farmers). The final section allowed respondents to submit any other comments and to give contact information (if they wished to receive the results of the study). Respondents could write additional comments and suggestions for each question (under the response 'other').

\subsubsection{Data collection and analysis}

The survey was performed through both face-to-face interviews and online questionnaires, with support from the academic institutions that participated in the joint EU project ReUseWaste $^{1}$. The electronic version of the questionnaire was designed using SurveyMonkey ${ }^{\mathrm{TM}}$. The questionnaire used for face-to-face interviews was the same as that used for the online survey. Data were collected between April 2014 and June 2015.

Survey dissemination strategies differed between countries. In DK, surveys were disseminated by researchers from the University of Copenhagen via an email that described the purpose and background context of the survey, and included a link to the online survey. Agricultural advisors were contacted via a database of advisors obtained from the Danish agricultural extension service (110 advisors were randomly selected; 32 of them completed the survey, Table 6-2). A list of other stakeholders was prepared via personal contacts. For instance, the questionnaires were emailed to 18 researchers with expertise in manure management and treatment (in Aarhus University, University of South Denmark and the University of Copenhagen), 20 officers in local and national governmental department (e.g. the Danish Environmental Production Agency, the Danish AgriFish Agency), and to the chairmen of 45 farmers' organizations in DK. Similarly to DK, all surveys were disseminated via email and completed online in NL. Requests were sent to target stakeholders (except for researchers) via the secretaries of two large (branch) organizations i.e., CUMELA and Nutrient Platform, and of the main farmers' organization LTO. ${ }^{2}$ Furthermore, a selection of 20 researchers from Wageningen UR with expertise in manure management and treatment were asked to complete the questionnaire. In ES, the questionnaire was completed online by

\footnotetext{
${ }^{1}$ ReUseWaste: http://www.reusewaste.eu/

${ }^{2}$ CUMELA: http://www.cumela.nl/, Nutrient Platform: http://www.nutrientplatform.org/, LTO: http://www.lto.nl/.
} 


\section{Chapter 6}

stakeholders from the research, industry, extension service and policy communities who were selected and contacted by researchers from the Spanish National Research Council (CSIC). The questionnaire was completed via face-to-face interviews with farmers, instead of by an online survey, as it was considered that farmers would generally have limited access to the internet and were not familiar with online questionnaires. Livestock farmers were visited at their homes (one by one) in regions of high livestock density (Murcia and Catalonia) by researchers from CSIC. These farmers were selected via the contact of local agricultural advisors and also according to their willingness to participate. A hard copy of the questionnaire was presented to the respondents. Interviewers were instructed not to present their own opinions, but only to clarify the questions in case farmers did not understand. Results of the face-to-face interviews were uploaded to the SurveyMonkey ${ }^{\mathrm{TM}}$ database and analyzed alongside online responses. In IT, stakeholders from the research, industry, extension service, and policy communities were surveyed during two national agricultural meetings held in 2014 (November and December), and further interviews were subsequently conducted via personal contacts of researchers from the University of Turin. Efforts were made to ensure the privacy of the face-to-face interviews, and respondents were interviewed one by one. Respondents representing livestock farmers and members of farmers' organizations came mainly from areas where animal husbandry is highly intensive, i.e. Northern Italy (Piedmont, Lombardy, Emilia Romagna and Veneto). In total across all the countries 291 surveys were completed; each stakeholder group had between 18 and 75 respondents (see Table 6-2 and Section 6.3).

Table 6-2. Overview of respondents as number per country.

\begin{tabular}{|c|c|c|c|c|c|}
\hline & DK & NL & ES & IT & Total \\
\hline \multicolumn{6}{|c|}{ Do you have experience in manure treatment? ${ }^{a}$} \\
\hline Yes & 73 & 66 & 55 & 45 & 239 \\
\hline No & 9 & 13 & 7 & 23 & 52 \\
\hline Total & 82 & 79 & 62 & 68 & 291 \\
\hline \multicolumn{6}{|l|}{ What is your job? ${ }^{b}$} \\
\hline Farmer & 10 & 18 & 35 & 12 & 75 \\
\hline Representative in a farmer organization & 10 & 3 & 3 & 5 & 21 \\
\hline Agricultural advisor & 32 & 6 & 1 & 10 & 49 \\
\hline Technology developer/ user in company & 17 & 30 & 4 & 7 & 58 \\
\hline Employee in the public authority & 8 & 1 & 3 & 6 & 18 \\
\hline Researcher & 7 & 18 & 15 & 23 & 63 \\
\hline Respondents skipped this question & 7 & 9 & 3 & 6 & 25 \\
\hline
\end{tabular}

${ }^{\mathrm{a}}$ single answer

${ }^{\mathrm{b}}$ multiple answers 
A draft of the survey was sent to researchers (more than 20 in total) in the four countries to improve clarity and reduce the chance of misinterpretation. Comments and suggestions on the draft questionnaires were used to modify the survey before distribution. The same survey was disseminated to the four target countries, but translated (into Danish, Dutch, Italian and Spanish). The link to the English version of the questionnaire (as example for Denmark) was attached in Appendix A.

Data downloaded from the SurveyMonkey ${ }^{\mathrm{TM}}$ were compiled and analyzed using $\mathrm{R}$ version 3.0.0 (e.g. Crosstab function) and Microsoft Excel 2010. The number of positive ticks to each option of a question (i.e. the number of respondents) was recorded. Results were analyzed by individual countries and also with the sum of all countries. Since there were multiple-response questions in the questionnaire, the absolute number of respondents referring to each answer of a question was converted to the percentage of the total number of respondents who answered the question. This conversion allowed for the comparison of different variables listed in a question, as well as a comparison between countries.

\subsection{Results}

Table 6-2 provides an overview of the number of respondents per stakeholder group and country. In total, 291 questionnaires were completed: $28 \%$ in DK, $22 \%$ in ES, $23 \%$ in IT, and $27 \%$ in NL. A total of $82 \%$ of the respondents had experience with manure treatment (Table 6-2). More than 50\% of those had experience with manure separation and anaerobic digestion, except for respondents in ES (Figure 6-2). Over $70 \%$ of respondents in DK had experience with slurry acidification. In ES, most respondents (40\%) had experience with composting. Respondents from NL had more experience with manure drying and membrane filtration (or reverse osmosis) (Figure 6-2). Few respondents answered that they had experience with alternative treatment technologies that were not offered as possible responses in the question, e.g. ammonia stripping from liquid manure, phosphorus recovery, or evaporation of liquid manure. 


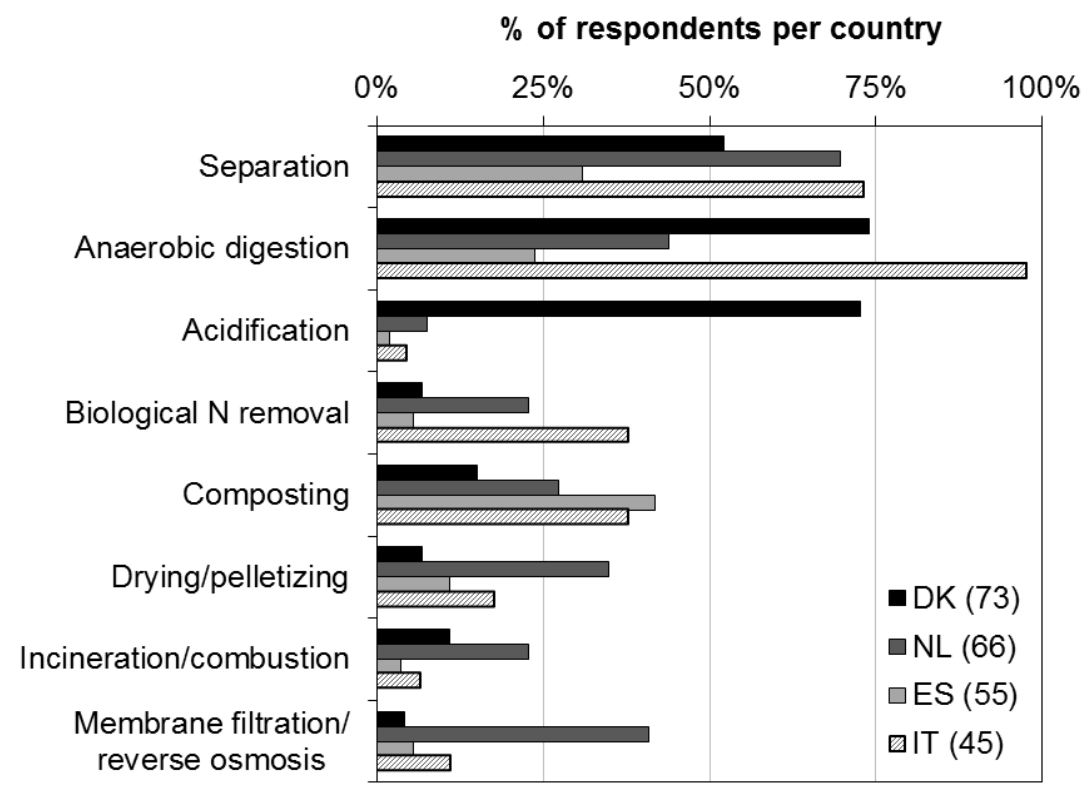

Figure 6-2. Response to the question: "please indicate the treatment technique(s) in which you are involved." (multiple responses permitted). The number of respondents per country with experience in manure treatment is shown in the legend.

\subsubsection{Factors that stimulate and hinder adoption}

Pressure from environmental policies was perceived to be the most important factor affecting the implementation of manure treatment in practice ( $70 \%$ of total respondents), which was the case for respondents from all four countries and all stakeholder groups (Figure 6-3; Appendix B.1). The need to facilitate the export of manure from the farm (47\%, especially in DK and NL) was also highlighted by many respondents. The need to achieve renewable energy targets by producing bioenergy from manure was ranked relatively highly in DK and IT. Compared to the other factors considered, the need to efficiently use manure nutrients due to increased fertilizer prices was considered relatively important in ES. For all countries, controlling diseases, pathogens and odor was considered the least important among the six factors defined in the survey (Figure 6-3). 


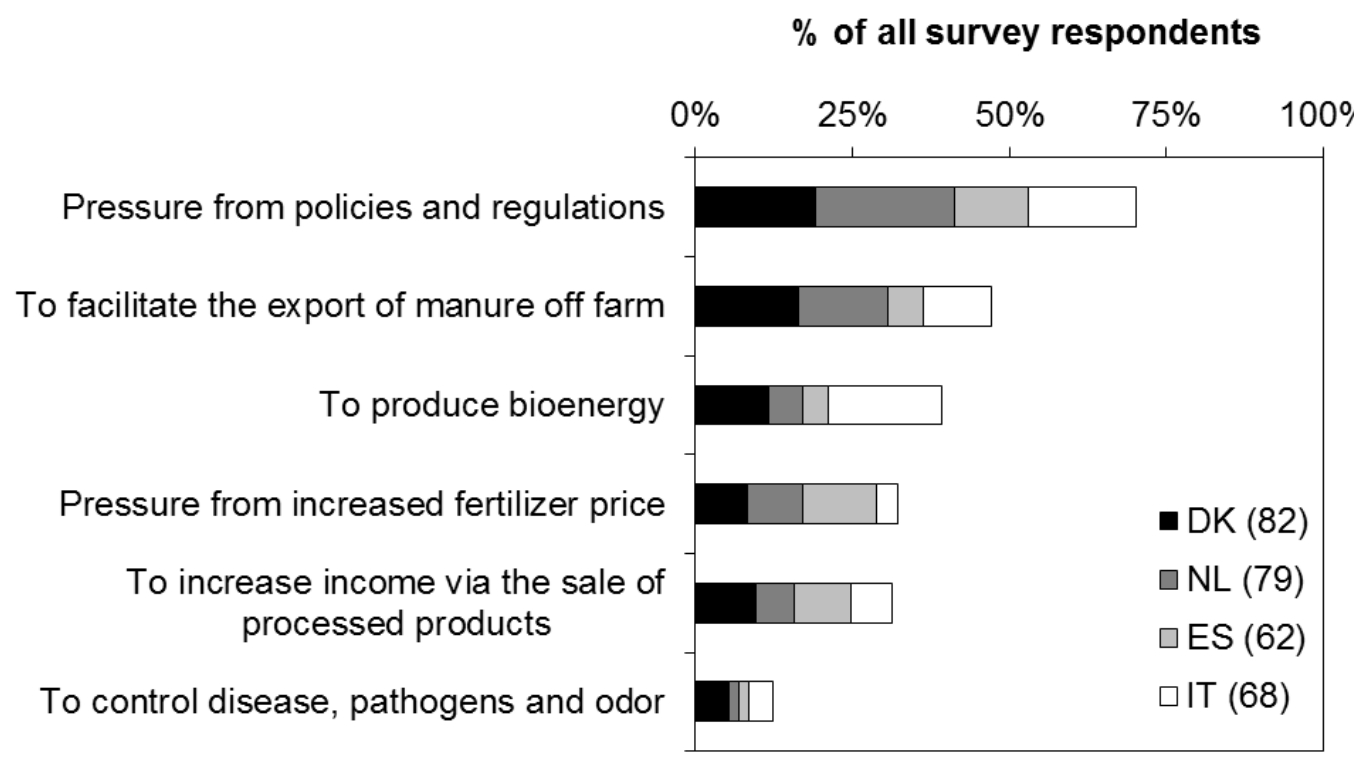

Figure 6-3. Responses to the questions (expressed as $\%$ of respondents from all survey countries): "please indicate the top three reasons that can stimulate farmers to apply manure treatment techniques." The number of respondents that answered this question is shown in the legend.

Economic factors were the main barriers to the implementation of manure treatment in practice, namely the lack of investment capital (60\% of total respondents), high processing costs $(52 \%)$, and long payback period (45\%). These barriers were perceived to be important for all countries (Figure 6-4) and by all stakeholder groups (Appendix B.2). Legal constraints (32\% of all respondents, highest at $45 \%$ in NL) and lack of knowledge (32\% of all respondents, especially in ES and IT) were chosen by a moderate number of respondents. Transport, noise burdens and health risks were not seen as important barriers among all stakeholder groups (Figure 6-4; Appendix B.2). Interestingly, livestock farmers and agriculture advisors had relatively little concern about the market for manure processing products (Appendix B.2). This suggested that these farmers were possibly interested in using processed organic fertilizers, which is confirmed by the results from a parallel study on farmer perceptions of organic fertilizers in Denmark (Case et al., unpublished results). 


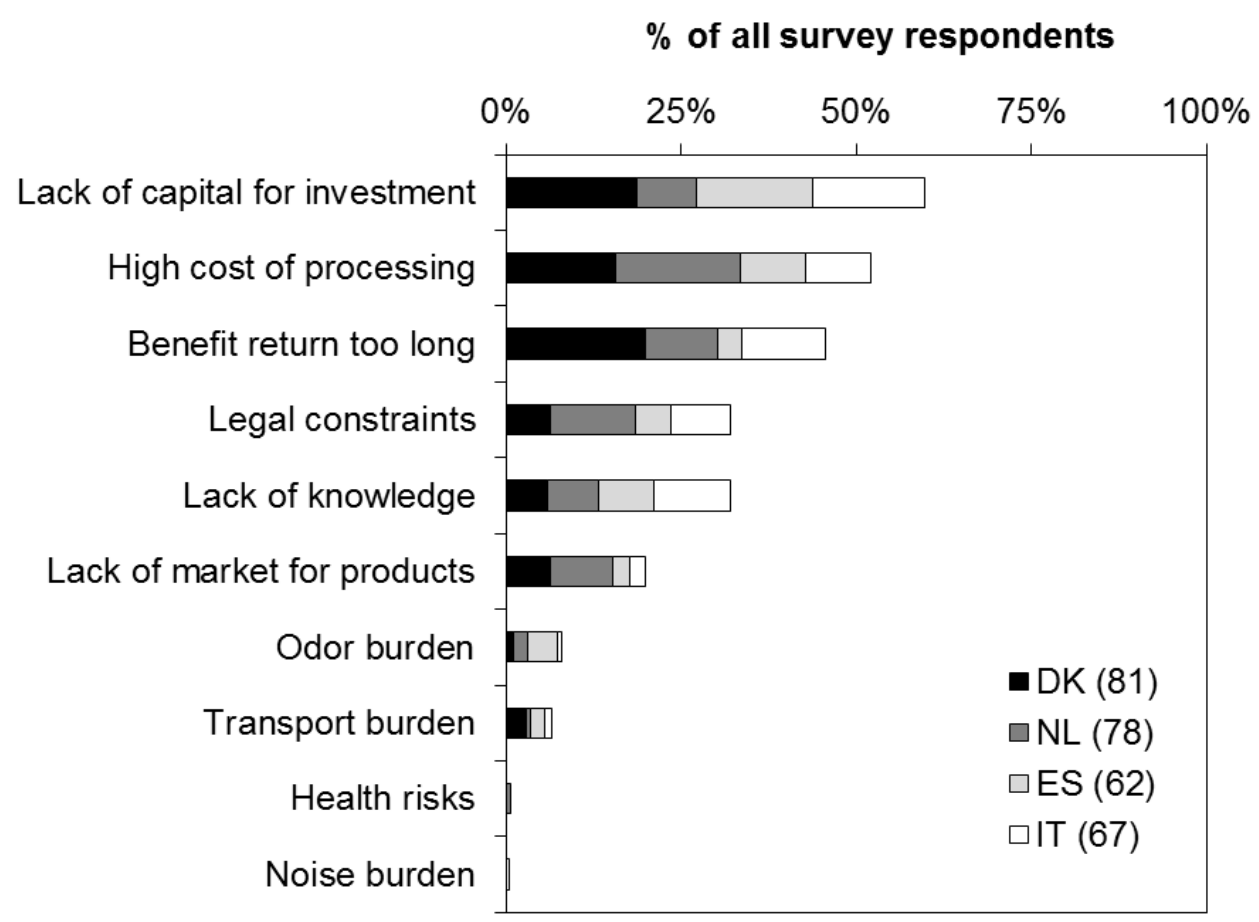

Figure 6-4. Responses to the questions (expressed as \% of respondents from all survey countries): "please indicate the three most important constraints / barriers to the adoption of manure treatment technologies." The number of respondents that answered this question in each country is shown in the legend.

\subsubsection{Preferred treatment technologies}

Stakeholders indicated that manure separation and anaerobic digestion had the greatest potential for a common adoption in practice (36\% and $42 \%$ of total respondents, respectively). Other technologies appear to be more country specific. There was a relatively high adoption potential for slurry acidification in DK (47\%) and composting in ES (44\%), while drying of solid manure fractions and membrane filtration (or reverse osmosis) of liquid fractions were considered positively in NL (Figure 5-5). 


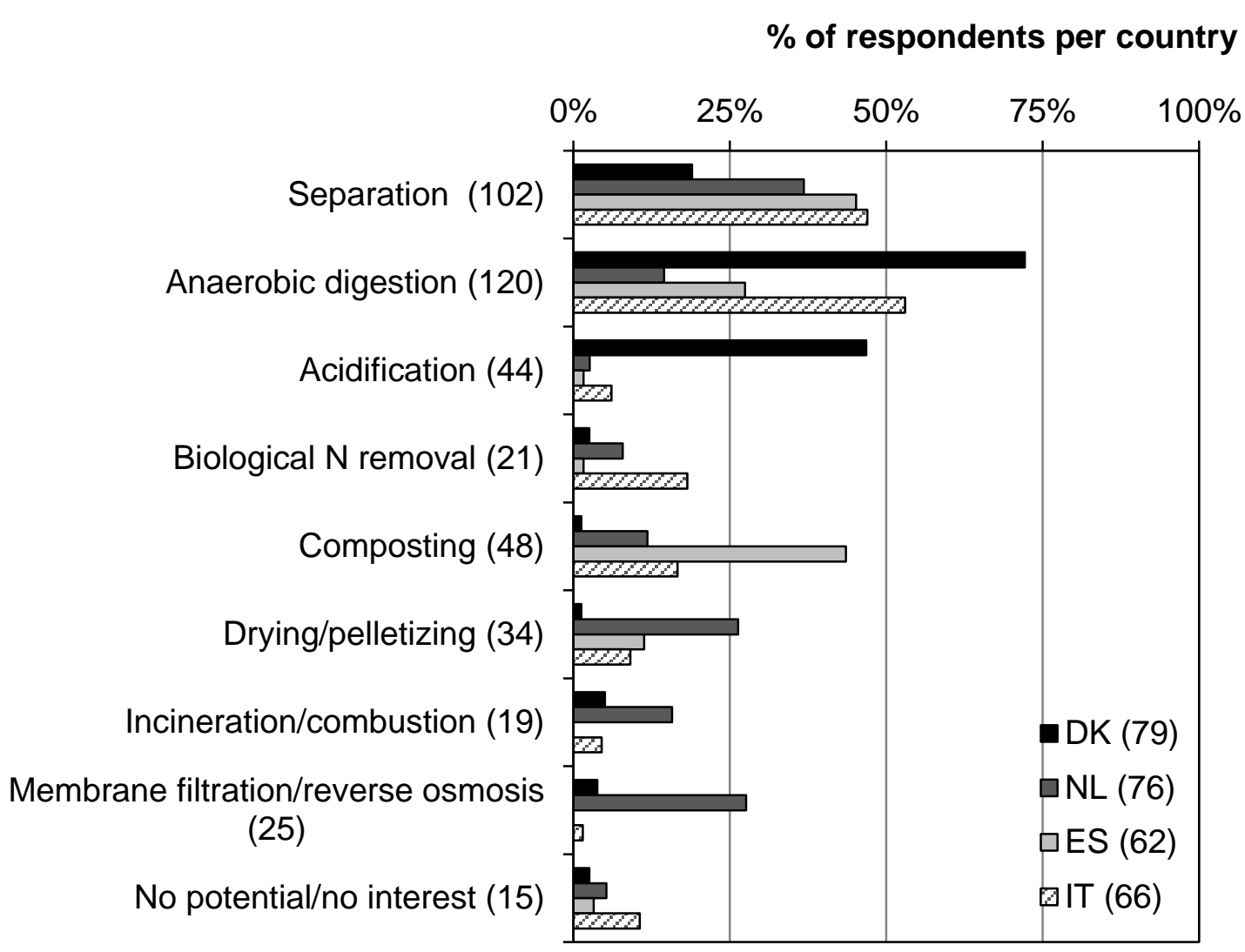

Figure 6-5. Response to the question: "which techniques have the most potential to be applied in your country during the next 10 years?" The number of respondents (answered this question) for each country is shown in the legend. The number of respondents for each technology/answer is indicated in the $\mathrm{Y}$-axis label.

\subsubsection{Preferred farm structure and scale of operation}

Figure 6-6 shows that livestock farms with a limited area of land were considered to have a relatively high adoption potential for all of the manure treatment technologies considered with the exception of slurry acidification (Figure 6-6a). This exception is possibly due to the fact that farms with sufficient land are more willing, or are required to use techniques that reduce ammonia losses from on-farm storage and application of manures. Overall, manure treatment was considered to be more applicable to pig and cattle farms than to poultry farms (Figure 66a). 


\section{Chapter 6}
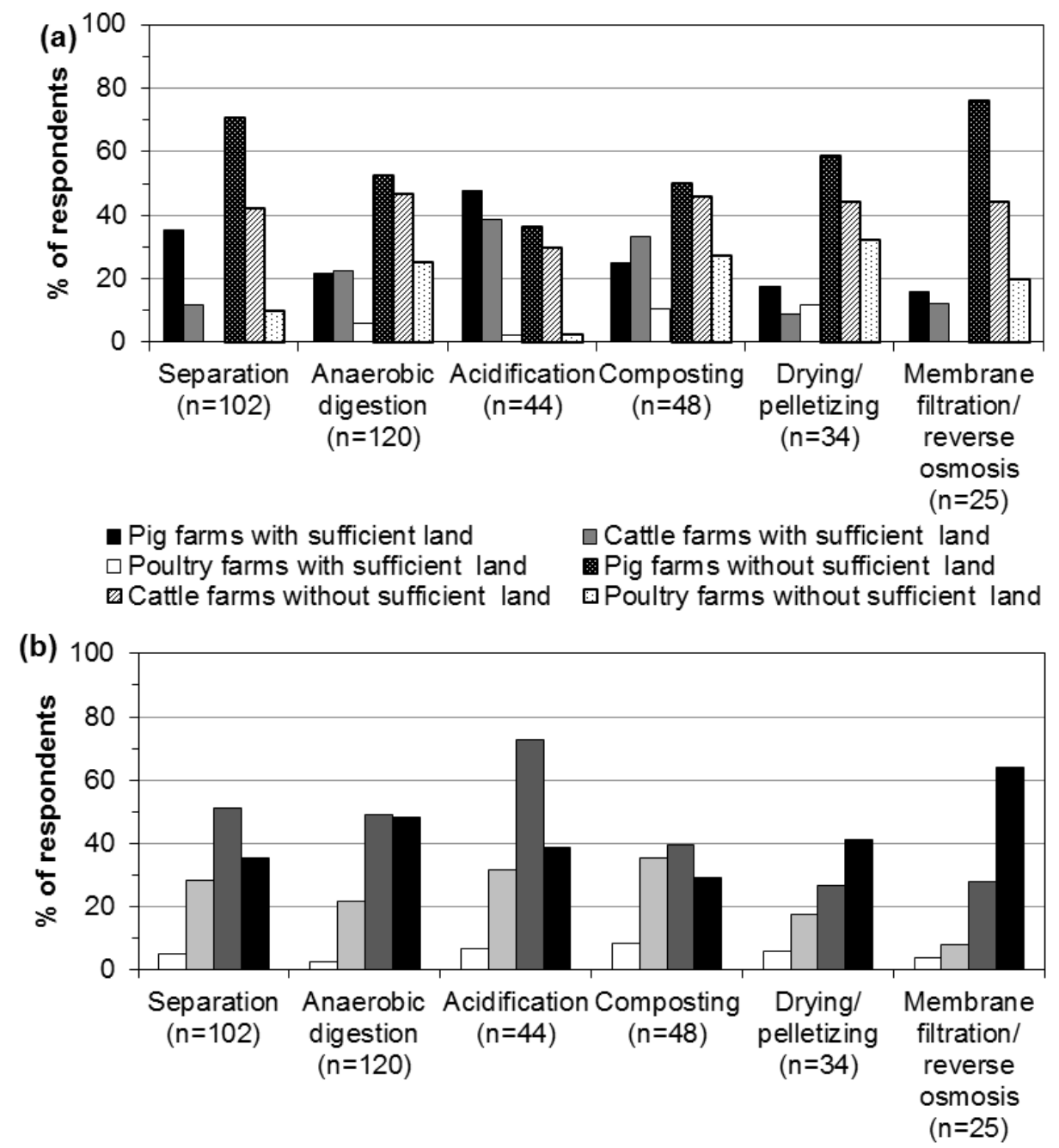

$\square<50$ LU $\quad \square 50-300$ LU $\quad \square 301-1000$ LU $\quad \square>1000$ LU

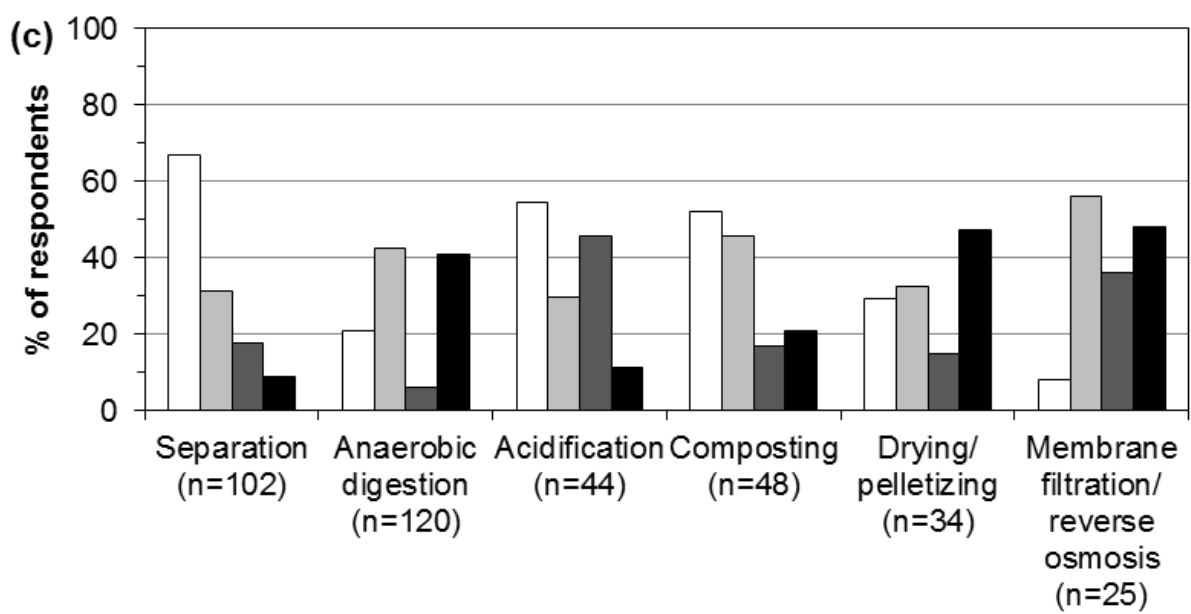

$\square$ Farm-scale $\square$ Farmer cooperatives $\square$ Contractors $\square$ Large, industrial scale

Figure 6-6. Responses to indicate which farm types (a), sizes (b, LU=livestock unit) and operation scales (c) have the most potential for adoption of respective technologies (multiple answers), expressed as \% of respondents for all four countries. The number (n) of respondents is shown for each technology. Results referring to biological nitrogen removal and incineration treatment are not shown due to limited number of responses. 
Manure treatment was considered to be less applicable to small livestock farms (i.e. $<50 \mathrm{LU}$ ). Drying and reverse osmosis technologies were perceived most appropriate for large livestock farms (> 1000 LU) (Figure 6-6b). Stakeholders had different views regarding the optimal scale of the manure treatment plant (Figure 6-6c). Separation (67\% of respondents), acidification (55\%) and composting (52\%) were perceived to be most applicable at the farm scale. Anaerobic digestion, drying (pelletizing) and membrane filtration were considered to be most applicable at the industrial scale and for farmer cooperatives (Figure 6-6c).

\subsubsection{Benefits of manure treatment}

Table 6-3 shows respondent perceptions of the benefits of manure treatment. A reduction in manure disposal costs and an increase in the fertilizer value of separated liquid and solid fractions were ranked as the main benefits of manure separation. For anaerobic digestion, the main benefits included bioenergy production, the increased fertilizer nitrogen value of digestate, and the reduction of odor and gaseous emissions during further processing and field application. Mitigation of ammonia emissions during slurry storage and application, and the increased fertilizer $\mathrm{N}$ value of slurry were ranked as the main benefits of slurry acidification. Increased organic matter quality of manure and improved soil quality after field application were ranked as the main benefits of composting.

\subsection{Discussion}

Currently, less than $10 \%$ of the animal manure produced in EU is treated and most farmers have little knowledge about manure processing technologies (Foged et al., 2011a). In the present study the survey was disseminated to stakeholders involved in manure treatment, directly or indirectly. This explains why over $80 \%$ of the respondents described themselves as having at least some experience with manure treatment. Most of the stakeholders contacted within each group (farmers, farmers' organizations, extension service, industry, policy and research) were considered to be forerunners in the whole domain of the development, implementation and management of manure treatment technologies. By exploring the views of these stakeholders engaged with manure treatment, a better understanding of the future perspectives of manure processing is possibly achieved. 


\section{Chapter 6}

Table 6-3. Summary of responses to the questions asking about the benefits of each respective technology (for all four countries), measured in \% of the total number of respondents for each question.

$\%$ of respondents

What are the top three benefits of separation? (Number of respondents: $n=102$ )

To reduce cost of manure disposal

To increase fertilizer value of liquid fractions

To increase fertilizer value of solid fractions

$\begin{array}{ll}\text { To use solid factions for biogas production } & 27\end{array}$

To use solid fractions for composting 25

To reduce ammonia emissions from liquid fractions after field application 18

To use solid factions as bedding materials 16

What are the top three benefits of anaerobic digestion? $(n=120)$

To produce bioenergy

To increase fertilizer nitrogen value of digestate 58

To reduce odor and gaseous emissions during processing 43

To reduce odor and gaseous emissions after field application of digestate $\quad 42$

To increase soil quality after field application of digestate 13

To increase fertilizer phosphorus value of digestate $\quad 8$

What are the top three benefits of acidification? $(n=44)$

To reduce ammonia emissions during field application $\quad 82$

$\begin{array}{ll}\text { To reduce ammonia emissions during storage } & 73\end{array}$

To increase fertilizer nitrogen value of slurry $\quad 68$

To increase fertilizer sulfur value of slurry $\quad 27$

To reduce greenhouse gas emissions during storage $\quad 25$

What are the top three benefits of composting? $(n=48)$

To improve the organic matter quality

To remove pathogens 46

To reduce the volume and mass of the manure $\quad 42$

To improve soil quality after field application of compost $\quad 42$

To increase economic value as compost products $\quad 40$

To reduce ammonia emissions after field application of compost $\quad 19$

To homogenize the manure $\quad 13$

What are the top three benefits of drying/ pelletizing? $(n=34)$

To facilitate export $\quad 59$

To increase the market value of the manure

To reduce costs of transporting manure surplus off farm 41

To increase soil quality after field application of dried products 29

To decrease ammonia emissions after field application of dried products 26

What are the top three benefits of membrane filtration/ reverse osmosis? $(n=25)$

To increase fertilizer effectiveness of nitrogen as concentrates 64

To make a K fertilizer $\quad 48$

To reduce cost of transporting phosphorus surplus off farm

To remove organic matter from liquid manures 28

To reduce ammonia emissions after field application of concentrates 12 


\subsubsection{Key factors that stimulate manure treatment in practice}

Pressure from environmental policies and regulations was identified as the most important stimulus for the implementation of manure treatment systems (Figure 6-3). This may reflect the fact that current policies and regulations implemented in these four countries have influenced stakeholder decisions on manure handling and management activities. A number of policies have been implemented by the EU and United Nations (UN) bodies to reduce environmental pollution from animal manures (Oenema et al., 2011), which play an important role in stimulating manure treatment activities in Europe. The EU Nitrates Directive sets up the maximum application limit of manure in NVZs, equivalent to $170 \mathrm{~kg} \mathrm{~N} \mathrm{ha}^{-1}$ year $^{-1}$ (European Commission, 1991). This limit obliges livestock farms to treat and/or to transport the excess manure to other farms. The EU National Emission Ceiling Directive (European Commission, 2001) aims to reduce emissions of ammonia $\left(\mathrm{NH}_{3}\right)$ (including from manures), and thereby stimulate the development of certain manure treatment technologies (Bittman et $a l .$, 2014). For example, acidifying slurry was introduced as one of the options for obligatory $\mathrm{NH}_{3}$ mitigation measures by Danish regulations in response to these EU Directives. On the other hand, the use of manure treatment may remain marginal in regions that have low pressure from these regulations. The authors conducted also a similar survey in Portugal, but the number of responses from targeted stakeholders was small and hence results are not shown. A low response rate from Portuguese stakeholders (in particular farmers) may reflect that the interest for manure treatment is low in regions that have sufficient land for application of the manure produced, as well as low pressure from governmental legislation. These results revealed that variations between countries in manure treatment have a strong relationship with variations in livestock density and national policies.

Producing bioenergy from animal manures was identified as an important reason for the adoption of manure treatment in practice, in particular in DK and IT (Figure 6-3). Anaerobic digestion produces biogas that can be used directly for heating, for combined thermal and electricity generation, or to upgrade to bio-methane that has similar characteristics to natural gas (Bernet \& Béline, 2009). Using animal manures as feedstock for biogas production has advantages compared to using energy crops, such as less competition with food production and higher mitigation potential of greenhouse gas emissions (De Vries et al., 2012). Further, the digestate can serve as an improved organic $\mathrm{N}$ fertilizer (Table 6-3). The development of biogas production in European countries has been influenced strongly by environmental 


\section{Chapter 6}

regulations and the EU Renewable Energy Directive (Edwards et al., 2015). The growth of anaerobic digestion in DK is largely due to policy incentives such as increased investment support for construction of biogas plants, the implementation of fossil energy taxes or renewable energy tariff subsidies and the government support strategies to increase interactions between various social groups (Raven \& Gregersen, 2007). Italy has also witnessed an extraordinary growth in biogas generation from animal manures and other agricultural biomass in the last few years, which is largely due to the biogas support programs implemented in Italy (the introduction of Tradable Green Certificate and feed-in-tariff, and increased investment subsides) (Chinese et al., 2014). In comparison, manure-based biogas producers in NL and ES face many financial and socio-political challenges (Fierro et al., 2014; Hoppe \& Sanders, 2014), which may explain why biogas production was perceived as less attractive in these two countries (Figure 6-3 and Figure 6-4).

The pressure from increased fertilizer price was perceived to be an important factor for stimulating manure treatment in ES (Figure 6-3), which is in line with the conclusion from a study that investigated the existing experience on manure treatment in Catalonia, a region with high animal density in ES (Flotats et al., 2009). The increase in prices of mineral fertilizers could explain the recent growth in composting facilities in Catalonia, in order to recover nutrients in organic forms and produce soil organic amendments that are economically valuable (Flotats et al., 2009). The need to facilitate off-farm manure export was considered to be relatively important in $\mathrm{NL}$ and $\mathrm{DK}$, where the average LU is high and a large portion of farms have been involved in manure exchange (Asai et al., 2014); it appears to be less important in ES partly due to the average low animal density (Figure 6-1).

\subsubsection{Key barriers to manure treatment in practice}

The most important barriers to the implementation of manure treatment in practice were related to economic factors (Figure 6-4). This corresponded with findings from several other studies. Results from a survey among 111 Dutch dairy farmers indicated that nearly half of respondents strongly disagreed with the statement that low cost of manure separation is a reason for them to consider the use of manure separation, while only $13 \%$ of respondents agreed (Gebrezgabher et al., 2015). Substantial upfront investments, subsidies not being granted, and increased price of co-feedstock were identified as important barriers for biogas producers in NL (Hoppe \& Sanders, 2014). In the present study, most respondents (who perceived that anaerobic digestion had the most potential for adoption) stated that subsidies 
for upfront investment and/or energy production were vital for anaerobic digestion of animal slurries in practice (data not shown). This confirms results from previous studies that subsidies play a large role in the profitability of biogas plants (Gebrezgabher et al., 2010; Chinese et al., 2014; Riva et al., 2014).

A number of respondents brought up legal constraints as an important issue hindering the implementation of manure treatment (Figure 6-3). A Dutch respondent indicated that "Licensing can be very restrictive in realizing initiatives, due to lack of objective knowledge (on manure processing) among local residents and licensing authorities". Likewise, a stakeholder study indicated that legal permits to operate biogas plants were difficult to attain in NL, partly because municipalities did not yet have specific biogas polices in place and therefore there were few staff trained in how to deal with permit requests for co-digestion plants (Hoppe \& Sanders, 2014). A Danish respondent also stated that "It is difficult or impossible to get authority approval for treatment operations, because of the resistance of the local community". Therefore, outreach strategies should be developed to provide more information to local residents, authorities, and extension services regarding the benefits and risks of manure treatment so as to increase social acceptability.

\subsubsection{Differences in priorities of technology adoption and operation structure}

The choice of prioritized technologies generally corresponded with the technologies for which respondents had experience (see Figure 6-2) and the status of manure processing activities in the countries surveyed (Foged et al., 2011a). An EU inventory study reported that slurry separation was used most in IT and ES; anaerobic digestion was predominantly applied in Germany, followed by IT and DK; and acidification operations were mainly located in DK, while ES had the largest share of composting operations (Foged et al., 2011a). In this study, composting was identified to have considerable growth potential in ES (Figure 6-4). This is partly because of the low soil organic matter content of arable land in ES $\left(<15 \mathrm{~g} \mathrm{C} \mathrm{kg}^{-1}\right.$; de Brogniez et al., 2015) and the ability to improve soil quality following the application of compost (Bernal et al., 2009). Composting was not ranked highly in DK and NL, where soil organic matter contents are relatively high (de Brogniez et al., 2015). Solid-liquid separation, drying of solid fractions and reverse osmosis of liquid fractions (to concentrates) were considered as attractive technologies for livestock farms with a limited area of land in NL (Figure 6-4). This may have been chosen due to the need to comply with policy regulations. Obligatory manure treatment was introduced in NL in 2013, which designated that livestock 


\section{Chapter 6}

farms with a manure surplus have to treat and/or to export a certain percentage of the surplus. Thus, the need to transport manures can greatly increase the use of treatment technologies that reduce the volume of liquid (separation and reverse osmosis) and solid fractions (drying and pelletizing). Manure-based anaerobic digestion was prioritized in DK (Figure 6-4), mainly due to Danish government policy. The Danish government proposed a target of using $50 \%$ of the manure produced in DK for renewable energy by 2020, which would need to be met through a strong expansion of biogas plants and capacity (Danish Ministry of Food, Agriculture and Fisheries, 2009).

Farm size and treatment plant operation structure are important for the implementation of manure treatment technologies (Flotats et al., 2009; Gebrezgabher et al., 2015). Clearly, landlimited large farms with >300 LU (representing farms with high animal density) have larger potential (or need) for the adoption of manure treatment than small farms (Figure 6-6). Separation and composting were generally considered to be farm-scale treatment technologies, while manure drying and reverse osmosis were considered most applicable at large, industrial scales (Figure 6-6). The complexity of the management and the costs of investments and processing varied among treatment technologies (Foged et al., 2011b). This may explain why the potential and suitability of technology adoption is related to the scale of farm and plant operations. Solid-liquid mechanical separation and composting are generally considered to be less complex in operation and of relatively low cost, compared to treatments such as anaerobic digestion and reverse osmosis (Flotats et al., 2009; Foged et al., 2011b). The annual gross costs (investment and operational costs) vary from $0.5-3 € \mathrm{t}^{-1}$ of inputs for mechanical separation and slurry acidification to $8-14 € \mathrm{t}^{-1}$ for anaerobic digestion and reverse osmosis, and their net processing costs on the basis of total $\mathrm{N}$ treated vary from $0.15-3 € \mathrm{~kg}^{-1}$ of $\mathrm{N}$ (Møller et al., 2000; Foged et al., 2011b). Processing manure in a cooperative form has advantages to reduce financial risks (to individual farmers) and treatment costs, and to make manure treatment viable for small- and mid-sized farms (Møller et al., 2000; Flotats et al., 2009; Swindal et al., 2010).

\subsection{Conclusions and recommendations}

Understanding the opinions of stakeholders closely engaged in manure treatment can enhance the effectiveness of programs designed to stimulate diffusion and exploitation of these technologies. Such an understanding is an essential part of attaining EU environmental and 
renewable energy targets. Based on the main findings from the present study, policy requirements, outreach strategies and future research needs are suggested.

Policy requirements. Pressure from governmental legislation was identified as the key stimulant of technology adoption, while barriers to adoption were mainly related to economic factors. It is recommended that policies for the promotion of manure treatment must be economically appealing to attract new adopters (farmers and industries). Long-term financial support schemes (e.g. subsidies) must be developed to encourage potential adopters to invest, considering the long-term investment requirements of manure treatment. It is also necessary to improve permit request procedures to facilitate their acquisition for operations. Large variations in technology preference between countries, farm types and scale of operation were observed in this study. These variations need to be considered when developing policy support schemes and marketing strategies.

Outreach strategies. More information should be conveyed to livestock farmers (especially those with large, land-limited farms) and other technology users regarding the different aspects of a specific technology, i.e. financial viability, optimal operation conditions (e.g. farm size, operation scale), regulations and incentives, and the agronomic and environmental performance of the technology. Better dissemination of this information to users would alleviate the lack of knowledge and experience and thus to assist with their decisions on technology adoption. Resources should be allocated to enable face-to-face, direct mail contact, as well as internet sources for dissemination of information. Outreach strategies need to be developed to convey these important environmental benefits of manure treatment to local residents so as to increase social acceptability.

Future research needs. This study emphasizes the importance of understanding stakeholder perceptions in countries with large areas of high animal density where manure treatment should be prioritized. However, manure treatment should not be limited to these regions, considering the potential benefits of manure treatment (e.g. not only environmental but also agronomic benefits). Thus, future research addressing the perceptions of stakeholders in regions with contrasting farming systems and socio-political conditions will complement the present findings and provide a more complete picture of the development of manure treatment.

Understanding stakeholder opinions about the development of manure treatment can assist in the design of policies and outreach strategies, leading to a better use of animal manures and a 
Chapter 6

sustainable production and management chain. The results from this study can serve as a basis for such efforts.

\section{Acknowledgments}

This research has received funding from the People Programme (Marie Curie Actions) of the European Union's Seventh Framework Programme FP7/2007-2013/under REA grant agreement no 289887. The results and conclusions achieved reflect only the authors' view and the Union is not liable for any use that may be made of the information contained therein. 
Appendix A: The link to online questionnaire (as example for Denmark):

https://www.surveymonkey.com/r/reusewasteDK_EN.

\section{Appendix B:}

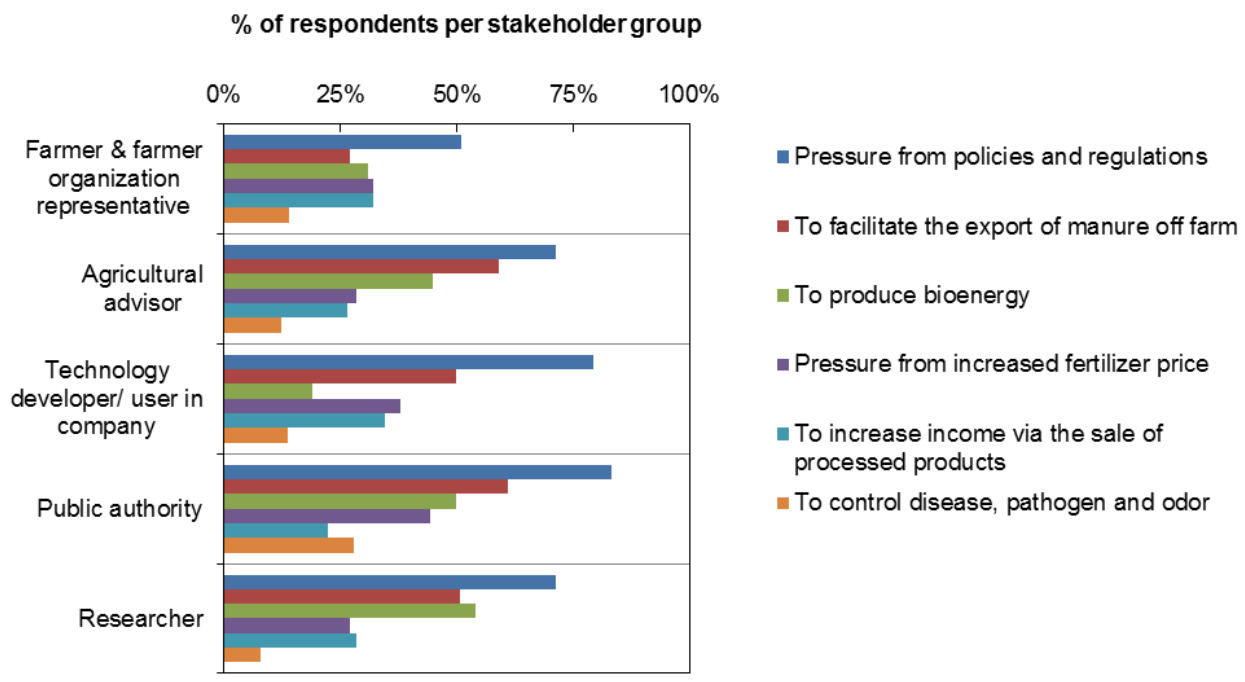

B.1. Responses to the question (multiple responses permitted): "please indicate the top three reasons that can stimulate farmers to apply manure treatment technologies." (presented as $\%$ of respondents per stakeholder group, for all survey countries). Due to a relatively low number of responses from farmer organizations, this stakeholder group was aggregated with the farmer group.

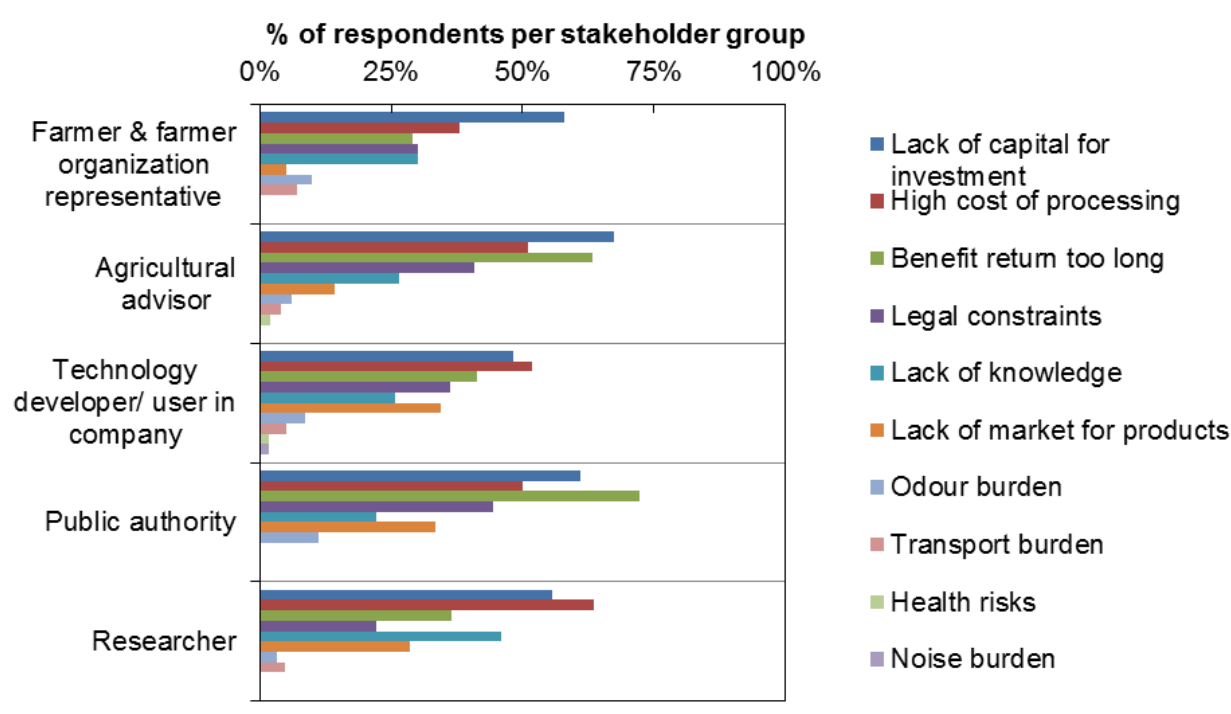

B.2 Responses to the question (multiple responses permitted): "please indicate the three most important constraints/ barriers for adoption of manure treatment technologies." (presented as \% of respondents per stakeholder group, for all survey countries). Due to a relatively low number of responses from farmer organizations, this stakeholder group was aggregated with the farmer group. 


\section{References}

Adhikari K, Hartemink AE, Minasny B, Bou Kheir R, Greve MB, Greve MH (2014) Digital mapping of soil organic carbon contents and stocks in Denmark. PLoS ONE, 9.

Asai M, Langer V, Frederiksen P, Jacobsen BH (2014) Livestock farmer perceptions of successful collaborative arrangements for manure exchange: A study in Denmark. Agricultural Systems, $128,55-65$.

Bernal MP, Alburquerque JA, Moral R (2009) Composting of animal manures and chemical criteria for compost maturity assessment. A review. Bioresource technology, 100, 5444-53.

Bernet N, Béline F (2009) Challenges and innovations on biological treatment of livestock effluents. Bioresource technology, 100, 5431-6.

Billen P, Costa J, Van der Aa L, Van Caneghem J, Vandecasteele C (2015) Electricity from poultry manure: a cleaner alternative to direct land application. Journal of Cleaner Production, 96, 467475 .

Bittman S, Dedina M, Howard C, Oenema O, Sutton M (2014) Options for Ammonia Mitigation: Guidance from the UNECE Task Force on Reactive Nitrogen. Centre for Ecology and Hydrology, Edinburgh, UK.

Blok V, Long TB, Gaziulusoy AI et al. (2015) From best practices to bridges for a more sustainable future: Advances and challenges in the transition to global sustainable production and consumption: Introduction to the ERSCP stream of the Special volume. Journal of Cleaner Production, 108, 19-30.

Bond T, Templeton MR (2011) History and future of domestic biogas plants in the developing world. Energy for Sustainable Development, 15, 347-354.

Chinese D, Patrizio P, Nardin G (2014) Effects of changes in Italian bioenergy promotion schemes for agricultural biogas projects: Insights from a regional optimization model. Energy Policy, 75, 189-205.

Dahlin J, Herbes C, Nelles M (2015) Biogas digestate marketing: Qualitative insights into the supply side. Resources, Conservation and Recycling, 104, 152-161.

Danish Ministry of Food, Agriculture and Fisheries, 2009. Aftale om Grøn Vækst. Copenhagen, Denmark. http://mst.dk/virksomhed-myndighed/landbrug/politiske-aftaler/groen-vaekst/ [accessed 06.06.15]

de Brogniez D, Ballabio C, Stevens A, Jones RJA, Montanarella L, van Wesemael B (2015) A map of the topsoil organic carbon content of Europe generated by a generalized additive model. European Journal of Soil Science, 66, 121-134.

De Vries JW, Vinken TMWJ, Hamelin L, De Boer IJM (2012) Comparing environmental consequences of anaerobic mono- and co-digestion of pig manure to produce bio-energy--a life cycle perspective. Bioresource technology, 125, 239-48.

Diacono M, Montemurro F (2010) Long-term effects of organic amendments on soil fertility. A review. Agronomy for Sustainable Development, 30, 401-422.

Edwards J, Othman M, Burn S (2015) A review of policy drivers and barriers for the use of anaerobic digestion in Europe, the United States and Australia. Renewable and Sustainable Energy Reviews, $52,815-828$.

European Commission (1991) Council directive of 12 December 1991 concerning the protection of waters against pollution caused by nitrates from agricultural sources. Official Journal of European Communisson, 1-8.

European Commission (2001) Directive 2001/81/EC of the European Parlia- ment and of the Council of 23 October 2001 on national emission ceilings for certain atmospheric pollutants. Off J Eur Union L 309:22. 
Fierro J, Gómez X, Murphy JD (2014) What is the resource of second generation gaseous transport biofuels based on pig slurries in Spain? Applied Energy, 114, 783-789.

Flotats X, Bonmatí A, Fernández B, Magrí A (2009) Manure treatment technologies: on-farm versus centralized strategies. NE Spain as case study. Bioresource technology, 100, 5519-26.

Foged HL, Flotats X, Blasi AB, Palatsi J, Magri A, Schelde KM (2011a) Inventory of manure processing activities in Europe. Technical Report No. I concerning "Manure Processing Activities in Europe" to the European Commission, Directorate-General Environment. 138 pp.

Foged HL, Flotats X, Blasi AB, Schelde KM, Palatsi J, Magri A, Juznik. Z (2011b) Assessment of economic feasibility and environmental performance of manure processing technologies. Technical Report No. IV to the European Commission, Directorate-General Environment. 130 pp.

Gebrezgabher SA, Meuwissen MPM, Prins BAM, Lansink AGJMO (2010) Economic analysis of anaerobic digestion-A case of Green power biogas plant in The Netherlands. NJAS Wageningen Journal of Life Sciences, 57, 109-115.

Gebrezgabher SA, Meuwissen MPM, Kruseman G, Lakner D, Oude Lansink AGJM (2015) Factors influencing adoption of manure separation technology in the Netherlands. Journal of Environmental Management, 150, 1-8.

Hoppe T, Sanders PTM (2014) Agricultural green gas demonstration projects in the Netherlands. A stakeholder analysis. Environmental Engineering and Management Journal, 13, 3083-3096.

Ingram J (2008) Are farmers in England equipped to meet the knowledge challenge of sustainable soil management? An analysis of farmer and advisor views. Journal of Environmental Management, $86,214-228$.

Kimming M, Sundberg C, Nordberg A, Baky A, Bernesson S, Hansson P-A (2015) Replacing fossil energy for organic milk production - potential biomass sources and greenhouse gas emission reductions. Journal of Cleaner Production, 106, 400-407.

Kowarsch M (2015) COMMENTARY : Policy assessments to enhance EU scientific advice. Nature Climate Change, 6, 1-5.

Leip A, Billen G, Garnier J et al. (2015) Impacts of European livestock production: nitrogen, sulphur, phosphorus and greenhouse gas emissions, land-use, water eutrophication and biodiversity. Environmental Research Letters, 10, 115004.

Møller H, Lund I, Sommer S (2000) Solid-liquid separation of livestock slurry: efficiency and cost. Bioresource Technology, 74, 223-229.

Montalvo C (2008) General wisdom concerning the factors affecting the adoption of cleaner technologies: a survey 1990-2007. Journal of Cleaner Production, 16, 7-13.

Nolan T, Troy SM, Gilkinson S et al. (2012) Economic analyses of pig manure treatment options in Ireland. Bioresource technology, 105, 15-23.

Oenema O, Bleeker A, Braathen NA et al. (2011) Nitrogen in current European policies. In: The European nitrogen assess ment (eds Sutton MA, Howard CM, Erisman JW, Billen G, Bleeker A, Grennfelt P, Grinsven H van, Grizzetti B), pp. 62-81. Cambridge University Press, Cambridge, UK.

Petit J, van der Werf HMG (2003) Perception of the environmental impacts of current and alternative modes of pig production by stakeholder groups. Journal of Environmental Management, 68, 377-386.

Raven RPJM, Gregersen KH (2007) Biogas plants in Denmark: successes and setbacks. Renewable and Sustainable Energy Reviews, 11, 116-132.

Reijneveld A, van Wensem J, Oenema O (2009) Soil organic carbon contents of agricultural land in the Netherlands between 1984 and 2004. Geoderma, 152, 231-238.

Riva C, Schievano A, D’Imporzano G, Adani F (2014) Production costs and operative margins in 


\section{Chapter 6}

electric energy generation from biogas. Full-scale case studies in Italy. Waste Management, 34, $1429-1435$.

Steinfeld H, Gerber P, Wassenaar T, Castel V, Roslaes M, De Haan C (2006) Livestock's long shadow. environmental issues and options. FAO report, Rome, Italy. 390 pp.

Sommer SG, Christensen ML, Schmidt T, Jensen LS 2013. Animal Manure Recycling: Treatment and Management. first ed. West Sussex, UK.

Swindal MG, Gillespie GW, Welsh RJ (2010) Community digester operations and dairy farmer perspectives. Agriculture and Human Values, 27, 461-474.

Van Dam J, Junginger M (2011) Striving to further harmonization of sustainability criteria for bioenergy in Europe: Recommendations from a stakeholder questionnaire. Energy Policy, 39, 4051-4066.

Van Der Meer HG (1987) Animal Manure on Grassland and Fodder Crops: Fertilizer or Waste?, Martinus Nijhoff, Dordrecht

Velthof GL, Lesschen JP, Webb J et al. (2014) The impact of the Nitrates Directive on nitrogen emissions from agriculture in the EU-27 during 2000-2008. The Science of the total environment, 468-469, 1225-33.

Viaene J, Van Lancker J, Vandecasteele B et al. (2016) Opportunities and barriers to on-farm composting and compost application: A case study from northwestern Europe. Waste Management, 48, 181-192. 


\title{
CHAPTER 7
}

\author{
General discussion
}




\section{Chapter 7}

\subsection{Introduction}

Animal manures are major sources of plant nutrients and soil organic matter. However, when not properly managed, these manures release also considerable amounts of ammonia $\left(\mathrm{NH}_{3}\right)$, nitrous oxide $\left(\mathrm{N}_{2} \mathrm{O}\right)$ and methane $\left(\mathrm{CH}_{4}\right)$ into the air, and nitrogen $(\mathrm{N})$ and phosphorus $(\mathrm{P})$ losses to water bodies via leaching and runoff, which create a range of unwanted environment impacts. In response, a large number of policy measures and manure treatment technologies have been developed, and part of these have been implemented in practice. Introducing a measure or technology to mitigate emissions from one source in the manure management chain may affect emissions also downstream in the chain, and may affect emissions of other pollutants, which may lead to synergistic or unwanted environmental side-effects (Sommer et al., 2009; Velthof et al., 2009). The trade-offs and co-benefits of emission mitigation measures and manure treatment technologies are poorly understood, especially when considering the whole manure management chain. Moreover, the effects of combinations of measures and technologies have not been well analyzed yet at regional and national scales.

The overall objective of my $\mathrm{PhD}$ thesis research is (i) to enhance the quantitative insight into the effects of emission mitigation measures and treatment technologies on the emissions of $\mathrm{NH}_{3}, \mathrm{~N}_{2} \mathrm{O}$ and $\mathrm{CH}_{4}$, and the recovery of $\mathrm{N}$ and $\mathrm{P}$ from animal manure in the whole chain from animal feeding to manure application to land, and (ii) to explore the effects of combinations of measures and technologies to mitigate these emissions consistently. This $\mathrm{PhD}$ thesis research was part of the Marie Curie Training Program ReUseWaste (Recovery and Use of Nutrients, Energy and Organic Matter from Animal Waste). In total eleven PhD students and two post docs have been working on various specific mitigation measures and treatment technologies. My research focused on the integral analysis of the whole manure management chain, and on the up-scaling and synthesis of research results, including those from literature. My research was split-up in four parts:

i) To allow for sound comparisons between countries and estimates at EU level, a harmonized and transparent methodology has been developed for the estimation of feed use and $\mathrm{N}$ and $\mathrm{P}$ excretion by the main animal categories, which is an essential first step for estimating manure-sourced emissions throughout the manure management chain (Chapters 2 and 3).

ii) To provide quantitative insights into the possible side-effects of $\mathrm{NH}_{3}$ emission mitigation measures, effects of these measures on emission of $\mathrm{NH}_{3}, \mathrm{~N}_{2} \mathrm{O}$ and $\mathrm{CH}_{4}$ at individual stages of the chain were assessed, using a meta-analysis approach. Further, the whole-chain impacts of 
a suite of $\mathrm{NH}_{3}$ mitigation measures on these emissions were explored for alternative manure management systems through scenario analyses, with emission parameters derived from the meta-analysis (Chapter 4).

iii) To estimate the environmental effects of treatment technologies in EU, gaseous emissions $\left(\mathrm{NH}_{3}, \mathrm{~N}_{2} \mathrm{O}\right.$ and $\left.\mathrm{CH}_{4}\right)$ and the recovery of $\mathrm{N}$ and $\mathrm{P}$ from animal manure in $\mathrm{EU}$ were assessed at country levels for the year 2010, using the improved MITERRA-Europe model, supplemented with a 'manure treatment' module developed in this study. Mitigation potentials of various treatment technologies and the associated impacts on nutrient recycling of manure in the EU were further examined through scenario analyses (Chapter 5).

iv) To increase the understanding related to the factors that affect the adoption of treatment technologies in practice, a survey of stakeholder perceptions of manure treatment technologies was conducted in four EU countries. All these countries have regions with high animal density, but diverse social-economic and environment conditions (Chapter 6).

In this chapter (Chapter 7), the main findings of my $\mathrm{PhD}$ thesis research are highlighted and discussed in a broader context. This chapter ends with a conclusion section, and a section in which future research needs are suggested.

\subsection{Main findings}

- In the EU-27, the total amounts of $\mathrm{N}$ and $\mathrm{P}$ in animal excretion produced annually are as large as or larger than the total annual amounts of fertilizer $\mathrm{N}$ and $\mathrm{P}$ used during last decades. However, there is a huge spatial variation in manure production. The methodologies used for estimating $\mathrm{N}$ (and P) excretion factors of animals differ between countries, and may also differ within countries between different policy reports. These differences hamper a sound comparison between countries and lead to uncertainties in total manure production and estimated emissions (Chapter 2). In an attempt to increase the accuracy of manure production estimates, I have developed a transparent and uniform methodology that couples feed availability in a country to $\mathrm{N}$ and $\mathrm{P}$ excretion rates at animal category and national levels, for all countries of the EU-27. This coupling allows to make checks of the plausibility of nutrient excretion values at the country level, and to arrive at a common basis for the estimation of the production of manure $\mathrm{N}$ and $\mathrm{P}$, nutrient balances and emissions across the EU (Chapter 3). 
- Increasing the effectiveness of mitigation measures for $\mathrm{NH}_{3}$ emissions from animal manure requires a manure management chain approach (Chapters 4 and 5). Lowering the crude protein (CP) content in animal feed (by an absolute value of about $1 \%$ to $5 \%$ ) significantly decreased $\mathrm{NH}_{3}$ emissions from animal housing (by 24-65\%, compared to the reference), and decreased emissions also from other management stages of the chain. External slurry storages with covers of straw and artificial films decreased $\mathrm{NH}_{3}$ emissions from storages by on average 78 and 98\%, respectively. This measure increases ammonium content of manure and, because of that, requires low-emission manure application measures to prevent increased downstream emissions. Lowemission manure application through incorporation and injection of manures in the soil may reduce $\mathrm{NH}_{3}$ emissions by 70 to $80 \%$, but tend to increase $\mathrm{N}_{2} \mathrm{O}$ emissions. The manure $\mathrm{N}$ that is conserved by using mitigation measures can be used to fertilize crops and to replace equivalent amounts of fertilizer $\mathrm{N}$. Measures taken to decrease $\mathrm{NH}_{3}$ emissions have relatively small effects on emissions of $\mathrm{CH}_{4}$ from the manure management chain, with the exception of slurry acidification. Slurry acidification significantly decreases emissions of $\mathrm{NH}_{3}$ and $\mathrm{CH}_{4}$ from slurry storages (83 and 87\%, respectively), which decreases total GHG emissions from systems with acidified slurry. Proper combinations of mitigation measures at farm level are therefore important to minimize impacts of livestock production on emissions of $\mathrm{NH}_{3}$ and GHG (Chapter 4).

- Effects of manure treatment on $\mathrm{NH}_{3}$ and GHG emissions from animal manures were relatively small in the EU-27 in 2010. Manure treatment have contributed to deceases in GHG emissions from manure by $0-17 \%$ depending on countries (compared to situations without manure treatment in 2010), with the largest contributions from anaerobic digestion (especially in Germany, Denmark and Italy). Scenario analyses indicated that increasing the implementation of slurry acidification, thermal (forced) drying, incineration and pyrolysis (implemented at a level of $20 \%$ of total manure production from housings for each technique) may decrease both $\mathrm{NH}_{3}(9-11 \%)$ and GHG (11-18\%) emissions from the manure management chain in the EU-27. Nitrification-denitrification treatment decreased $\mathrm{NH}_{3}$ emissions (8\%), but increased GHG emission (6\%) due to increased $\mathrm{N}_{2} \mathrm{O}$ emissions. Solid-liquid separation (8-12\%, depending on separators) and anaerobic digestion (19\%) deceased GHG emissions, while the effects on whole-chain emissions of $\mathrm{NH}_{3}$ were small. Combining acidification with separation or with anaerobic digestion (acidifying digested liquid 
fraction) decrease both GHG (18-20\%) and $\mathrm{NH}_{3}$ (7-10\%) emissions from the manure management chain. Composting marginally affected total $\mathrm{NH}_{3}$ emissions; emissions increased during composting and decreased emissions from application of compost to land. Composting also not affected GHG emissions significantly; there is a large variability/uncertainty in GHG emission factors during composting (Chapter 5).

- The estimated amounts of $\mathrm{N}$ and $\mathrm{P}$ in manure applied to land, expressed as percent of $\mathrm{N}$ and $\mathrm{P}$ excreted in animal housings in EU-27 in 2010, were 57 and 98\%, respectively. When increasing the implementation of treatment technologies (to an equivalent of $20 \%$ of total manure production in housings in all countries of the EU), the $\mathrm{N}$ recovery fraction would increase to $61 \%$ by acidification, but would decrease to $48 \%$ by incineration and to $52 \%$ by nitrification-denitrification treatment. Other technologies (solid-liquid separation, anaerobic digestion, drying, composting etc.) would only marginally affect the $\mathrm{N}$ recovery. Changes in the total $\mathrm{P}$ recovery due to all these technologies were relatively small, but there are likely differences between manure treatment products in $\mathrm{P}$ availability, which was not examined in my thesis. The N/P ratio of liquid manure products from treatment technologies varied from 3.4 to 10.7, compared to a mean of 3.5 in untreated slurry. For solid manure products, the N/P ratio ranged from 0.1 to 3.2 , compared to 3.0 in raw solid manure in the reference. Production of manure products that vary in N/P ratio provides opportunities to better use manure nutrients and to better meet nutrient demands by crops (Chapter 5).

- Pressure from governmental regulations is a key factor that stimulates the development and adoption of manure treatment in practice in countries that have regions with high livestock density (Denmark, Italy, Spain, the Netherlands). The major barriers to technology adoption were related to economic factors, while there was relatively little concern regarding transport and noise burdens and health risks (Chapter 6).

- Slurry separation and anaerobic digestion were generally perceived to have the greatest potential for a common adoption in practice in all four countries. Other preferred technologies were more country-specific. Stakeholders had different views on the optimal scale of the manure treatment plant because of the differences in investment cost and complexity of treatment technologies. Manure treatment will remain a regional activity because of large differences between regions/nations in livestock densities and socio-economic, political and environmental conditions. To encourage the adoption of manure treatment, policies must be economically appealing 
to attract new adopters (farmers and industries); long-term financial support schemes (e.g. subsidies) seem to be necessary. Outreach strategies are required to convey the knowledge to stakeholders from both the supply and the demand side, with respect to the economic, technical and environmental aspects of treatment technologies (Chapter $6)$.

\subsection{The manure management chain approach}

Measures and technologies taken to mitigate emissions from animal manures have to be optimized while taking the whole manure management chain into account (Petersen et al., 2007). The 'chain approach' allows for the analysis of the consequences of a technology, implemented at one stage of manure management, on the emissions at other stages, and also on emissions of other pollutants. The manure management chain concept (Figure 7-1) includes all main sectors, namely animal feeding, animal grazing and housing, manure storage and treatment, and application of manure to land. There are complex nutrient transfers and transformations within the chain.

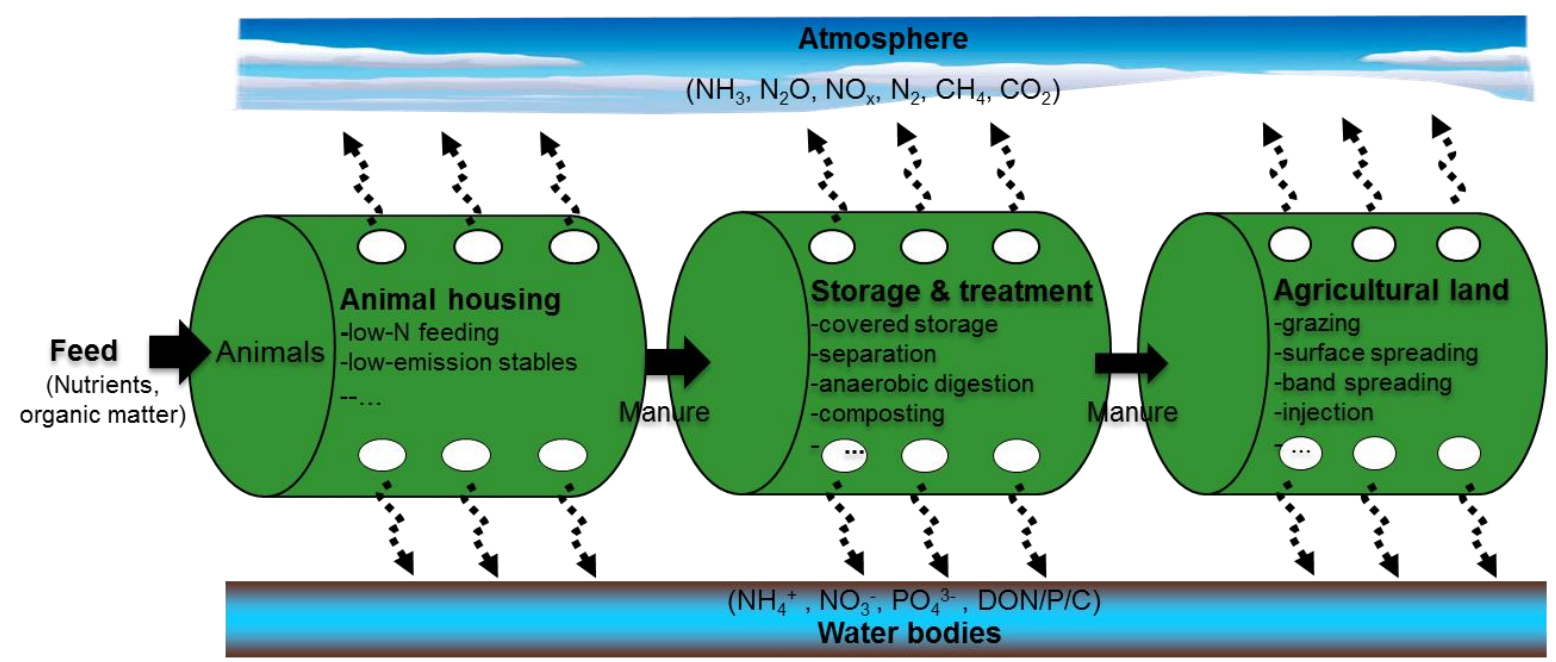

Figure 7-1. A simplified representation of different stages (including management practices) in the manure management chain. Dashed arrows show possible losses of nutrient elements to the atmosphere and to water bodies.

Several studies have been conducted to analyze gaseous emissions $\left(\mathrm{NH}_{3}, \mathrm{~N}_{2} \mathrm{O}\right.$ and/or $\left.\mathrm{CH}_{4}\right)$ from animal agriculture in general and animal manure in particular in EU countries, including e.g., Denmark (Hutchings et al., 2001), France (Gac et al., 2007), Ireland (Hyde et al., 2003), 
Switzerland (Reidy et al., 2008; Kupper et al., 2015), The Netherlands (Velthof et al., 2012), UK (Webb \& Misselbrook, 2004). These analyses were generally based on a mass flow approach. By using such approach, the consequences of abatement measures can be assessed at various stages of the manure management chain. However, it is difficult to make proper comparisons between countries, because these studies often used different system boundaries, emission factors and calculation methodologies.

Life cycle assessment (LCA) is an effective approach to analyze a wide range of environmental emissions along the entire life cycle of a product. LCA has been increasingly applied in environmental assessments of animal production (e.g. milk, pork and eggs) during the last decade. More recently, LCAs of treatment technologies have been conducted, such as for solid-liquid separation (ten Hoeve et al., 2014), anaerobic digestion (Sandars et al., 2003; Hamelin et al., 2011; De Vries et al., 2012; Mezzullo et al., 2012) and pyrolysis and combustion processes (Fernandez-Lopez et al., 2015). These LCAs were carried out in general at farm-scale, and the challenge therefore remains to up-scale the findings to regional/national levels. These LCAs often focus on a specific treatment technology or a specific type of manure only. The focus in my study was on the national and EU scale, considering the major manure types and the most used treatment technologies. Assessment was made with the MITERRA-Europe model.

The MITERRA-Europe is an integrated environmental assessment model, which quantifies all $\mathrm{N}$ and $\mathrm{P}$ flows as well as GHG emissions in agriculture for all member states of the EU at regional and national scales, using a uniform method and consistent dataset (Velthof et al., 2009; Lesschen et al., 2011). The model is partially based on information from the GAINS model (Asman et al., 2011) and CAPRI model (Britz \& Witzke, 2012). To fulfill the objectives of my $\mathrm{PhD}$ research, the model MITERRA-Europe was further improved. The main improvements are as follows: i) $\mathrm{N}$ and $\mathrm{P}$ excretion are quantified using the feed balance approach at animal category and country levels; ii) the estimation of possible side-effects of mitigation measures has been improved; iii) the environmental effects of a range of manure treatment technologies can be analyzed simultaneously at national scales now; iv) the recovery of $\mathrm{N}$ and $\mathrm{P}$ from animal manure can be quantified now; these recoveries are sensitive to changes in management along the chain.

There is scope for further improvement of the MITERRA-Europe model. 
- Regional specific data on the implementation of mitigation measures are required to decrease the uncertainties of the model outcome. However, such data are not easy to obtain. The EU-wide 'Survey on agricultural production methods (SAPM)' was a one off survey in 2010 to collect farm level data on agri-environmental measures to support monitoring of the relevant European Union policies (http://ec.europa.eu/eurostat). The SAPM data have been assessed for using them in the scenario analyses in Chapter 5. However, some flaws and inconsistences were found in the database, which hamper its proper use. For example, i) animal housing regarding the category 'other' is not clearly defined; ii) housings are not distinguished between dairy cows and other cattle; iii) definitions of manure storage facilities are too complex to be properly interpreted; iv) data on application of manure are not detailed at animal category levels. Evidently, it is difficult to use this SAPM dataset for modeling purposes.

- In the MITERRA model, it was assumed that all manure treatment activities take place as soon as manures are produced by animals or after removal from the housings. However, this is not always the case in practice. Often, there is a period of storage prior to treatment, but there is currently no information available about possible interim storage. As a consequence, the effectiveness of manure treatment may have been overestimated in my study. Moreover, there is lack of activity data on manure treatment technologies at animal category, regional and country levels, which contributes also to uncertainties in the model outcome.

- There are uncertainties in model parameters, especially emission factors, which contribute to the overall uncertainty of the results (Chapter 5). Country specific parameters have been used in the MITERRA model when such data were available. However, monitoring data on emissions from animal manures are still insufficient (Chapter 4), especially regarding gaseous emissions from treated manures, and leaching of $\mathrm{N}$ and $\mathrm{P}$ from stored manures. Evidently, there is a need to improve the accuracy of regionally specific emissions factors for manure treatment activities.

\subsection{A harmonized and transparent methodology for estimating feed use and nutrient excretion at national level.}

Accurate estimating nutrient excretion by livestock is the first step towards improving nutrient cycling and mitigating gaseous emissions in the manure management chain. Variations in $\mathrm{N}$ excretion factors affect the calculated emissions of $\mathrm{NH}_{3}$ and $\mathrm{N}_{2} \mathrm{O}$ directly. The basis for the 
calculation of $\mathrm{N}$ excretion factors should be the input-output balance method, i.e. ( $\mathrm{N}$ excretion) $=($ feed $\mathrm{N}$ intake $)-(\mathrm{N}$ retention in animal products, such as milk, eggs and live-weight gains $)$. The input-output balance method is firmly grounded on the commonly accepted law of mass conservation. The input-output balance can be applied at animal level, farm level, as well as at national level. National studies that include all animal categories allow to check the feed balance (Eshel et al., 2014a); do the total supplies of feed resources in a country indeed match well with the sum of the estimated national feed demand by all animal categories?

The national feed balance provides also a check of the accuracy of $\mathrm{N}$ excretion coefficients, and is a basis for the analysis of emission mitigation potentials of animal diet-related strategies. In addition, linking feed use to specific animal categories allows also to allocate feed production related resource use (e.g., land, water, fertilizers) and greenhouse gas emissions to individual animal categories and animal food products (Tilman \& Clark, 2014). Ranking various animal products according to the associated environmental (e.g., $\mathrm{N}$ footprints) and human health impacts can facilitate the implementation of revised dietary recommendations (Eshel et al., 2014b; Galloway et al., 2014).

In Chapter 3, a transparent and uniform methodology for estimating $\mathrm{N}$ excretion rates of the main animal categories was developed and applied for all Member States of the EU, through linking statistical data and information on the availability (quantity and quality) of feed with animal numbers and the energy and protein requirements of the animals. The allocation of feed resources to animal categories was based on a set of constraints and an optimization routine. Results show that annual $\mathrm{N}$ excretion factors per animal category varied greatly between countries (80-140 $\mathrm{kg} \mathrm{N}$ for dairy cows, $40-70 \mathrm{~kg} \mathrm{~N}$ for other cattle, 6-12 $\mathrm{kg} \mathrm{N}$ for pigs), which is mainly caused by differences in feed use and animal productivity.

The methodology developed in Chapter 3 has also some limitations, and the methodology therefore needs to be improved and validated further. Firstly, the cross-border trade of live animals are not included in my calculations. Although the number of traded live animals for each country is recorded yearly in Eurostat, the live-weights of these animals are unknown. Since the live-weight is a crucial factor determining the energy requirements for animal maintenance and growth, such data are required to improve the accuracy of this methodology. Secondly, the constraints employed in the feed optimization routine were considered to be uniform for the majority of countries. These assumptions to some extent mask variations in the estimated feed use between countries. While this feed model is designed to enable the use 


\section{Chapter 7}

of country-specific constraints, there is often insufficient information on these constraints, such as the ranges in the feed allocation to animal diets. The results from this model can be further validated by using regional and national statistical data on animal diets, such as those in the Netherlands (CBS, 2012). Furthermore, animal categories defined in my model are similar to those of the Farm Structure Survey, but the category 'other cattle' needs to be further refined to functional cattle categories (calves, beef cattle, suckling cows), which requires that the numbers, live-weight and feed requirements have to become available for these categories. Finally, national specific data on yields, mean energy and protein-N contents in grass and forages can be used to further improve the accuracy of estimating national total $\mathrm{N}$ excretion, as indicated in Chapter 3 (e.g. the sensitivity analyses). The suggested aforementioned improvements require additional information and data, which are not always easy to obtain, and this limits the applicability of the suggested improvements.

\subsection{Impacts of mitigation measures and treatment technologies on emissions}

The meta-analysis (Chapter 4) and the whole-chain analyses (Chapter 5) provide quantitative insights into the co-benefits and trade-offs of the main emission mitigation measures and treatment technologies.

Animal manures are responsible for about $80 \%$ of the total $\mathrm{NH}_{3}$ emissions in EU-27 (EEA, 2014; Leip et al., 2015). To comply with the UN-ECE Gothenburg Protocol, the EU National Emission Ceilings Directive (NECD, 2001/81/EC), and the EU Industrial Emissions Directive (IED, 2010/75/EU; the former IPPC Directive, 2008/1/EC), a variety of $\mathrm{NH}_{3}$ mitigation measures for reducing emissions from animal manures have been developed and implemented in EU, but with large differences between countries. Estimating the effectiveness of mitigation measures can therefore have implications for the EU environmental policies. Scenario analyses in Chapter 4 indicate that implementation of single measures can decrease total $\mathrm{NH}_{3}$ emissions from a slurry-based farming system by $9-29 \%$ (Table 7-1). At the EU-27 level, it was estimated that maximum implementation of single $\mathrm{NH}_{3}$ mitigation measures may lead to $1-18 \%$ of reduction, compared to a situation without measures (Velthof et al., 2009). The effects at the EU level also depend on the nature of livestock production systems; the mitigation measures are mostly applicable for manure produced from housed animals, and much less for manure from grazing animals. Application of manure with low emission approaches appears to have the largest abatement potential, followed by low-N feeding and covering manure storages (Table 7-1). The $\mathrm{NH}_{3}$ abatement potential is strongly increased if 
measures are combined. The abatement potential in the EU-27 was relatively low compared to that in the developing countries, such as China, where the agri-environmental regulations are as yet not well-established and mitigation measures are not implemented yet (Ma et al., 2013). A decrease of up to $45 \%$ of total $\mathrm{NH}_{3}$ emissions from pig production systems in China may be achieved with adoption of low-emission animal houses and manure storages (Bai et al., 2014).

Table 7-1. Summary of effects of the implementation of $\mathrm{NH}_{3}$ emission mitigation measures on emissions at farm and EU-27 levels, compared to a situation without measures.

\begin{tabular}{|c|c|c|c|c|c|c|}
\hline \multirow{3}{*}{$\mathrm{NH}_{3}$ emission mitigation measures } & \multicolumn{6}{|c|}{ Changes in emissions, in \% } \\
\hline & \multicolumn{3}{|c|}{ At farm level ${ }^{\mathrm{a}}$} & \multicolumn{3}{|c|}{ At EU level ${ }^{b}$} \\
\hline & $\mathrm{NH}_{3}$ & $\mathrm{~N}_{2} \mathrm{O}$ & $\mathrm{CH}_{4}$ & $\mathrm{NH}_{3}$ & $\mathrm{~N}_{2} \mathrm{O}$ & $\mathrm{NO}_{3}$ leaching \\
\hline Low-N feeding (Diet) & -18 & -1.4 & 0 & -4 & -2 & -2 \\
\hline Covering manure storages (Cover) & -9 & 2131 & -48 & -1 & 0 & 0 \\
\hline Low-emission manure application & & & & -18 & 12 & 3 \\
\hline Band application & -23 & 0 & 0 & & & \\
\hline Slurry injection & -29 & 91 & 0 & & & \\
\hline \multicolumn{7}{|l|}{ Combinations of measures } \\
\hline Straw (Cover) + slurry injection & -45 & 124 & -3 & & & \\
\hline Plastic (Cover) + slurry injection & -49 & 119 & -40 & & & \\
\hline Diet+ straw + injection & -66 & 95 & -3 & & & \\
\hline Diet+ Plastic +injection & -69 & 90 & -40 & & & \\
\hline \multicolumn{7}{|l|}{ Low-emission application } \\
\hline + Balanced $\mathrm{N}$ application & & & & -24 & -15 & -29 \\
\hline
\end{tabular}

${ }^{a}$ refers to scenario analyses for the model liquid-based pig farm in Chapter 4

${ }^{\mathrm{b}}$ refers to scenario analyses with maximum country-specific implementation of measures in EU-27 (Velthof et al., 2009); effects on $\mathrm{CH}_{4}$ emissions were not analyzed.

Implementation of single measures (except low- $\mathrm{N}$ feeding) may increase $\mathrm{N}_{2} \mathrm{O}$ emissions (Chapter 4) and $\mathrm{NO}_{3}$ leaching from soil (Velthof et al., 2009). The possible increases in $\mathrm{NO}_{3}$ leaching from soil take place when no supplemental measures are taken to correct for the increased soil $\mathrm{N}$ surplus. This follows in part from the "hole in the pipe" theory (Figure 7-1), i.e. blocking one of the holes in the pipe usually leads to increased leakages from other holes (i.e. pollution swapping), unless the $\mathrm{N}$ input is decreased and/or $\mathrm{N}$ output in useful products is increased proportionally (Oenema et al., 2009). Therefore, it is recommended that $\mathrm{NH}_{3}$ emission mitigation measures are combined with balanced $\mathrm{N}$ fertilization (Schröder et al., 2007; Oenema et al., 2009; Velthof et al., 2009). Low-N feeding is an effective strategy to decrease $\mathrm{N}$ (e.g. $\mathrm{NH}_{3}, \mathrm{~N}_{2} \mathrm{O}$ and $\mathrm{N}_{2}$ ) emissions from the whole manure management chain, without unwanted side-effects. When the protein content of the animal feed decreases by a moderate range (up to $10 \%$, relative to reference) in EU-27, $\mathrm{NH}_{3}$ emissions from manures 


\section{Chapter 7}

decrease by up to $6 \%$. The scope of abatement by low-N feeding largely depends on the current protein content in animal feed and on the economics of low-N feeding (see Section 7.7).

Table 7-2. Effects of increased implementation of manure treatment technologies on $\mathrm{NH}_{3}$ and GHG emissions and on nitrogen $(\mathrm{N})$ recovery from manure in the EU-27, compared to a situation without treatment in 2010. It is assumed that $20 \%$ of the total manure production from housings is treated by each of the technologies. Technologies have been defined in Chapter 5 .

\begin{tabular}{lcccc}
\hline Technologies & \multicolumn{4}{c}{ Change in emissions and N recovery, in \% } \\
\cline { 2 - 5 } & $\mathrm{NH}_{3}$ & $\mathrm{~N}_{2} \mathrm{O}$ & $\mathrm{CH}_{4}$ & $\mathrm{~N} \mathrm{recovery}^{\mathrm{a}}$ \\
\hline Screw press & -1 & -1 & -7 & 1 \\
Decanter centrifuge & -1 & -1 & -11 & 1 \\
Anaerobic digestion (AD) & 0 & -2 & -17 & 1 \\
Acidification (Acid) & -10 & 0 & -18 & 7 \\
Nitrification-denitrification & -8 & 24 & -18 & -9 \\
Composting & -2 & -2 & -6 & 2 \\
Thermal drying & -9 & -5 & -7 & 2 \\
Incineration & -11 & -4 & -7 & -16 \\
Pyrolysis & -11 & -5 & -7 & -9 \\
Combination of techniques & & & & \\
Acid-centrifuge & -10 & 0 & -19 & 7 \\
Centrifuge-Acid, pyrolysis & -7 & -1 & -19 & 0 \\
AD-Acid-centrifuge & -7 & 0 & -17 & 5 \\
\hline
\end{tabular}

${ }^{a}$ Nitrogen recovery is defined here as the fraction of total $\mathrm{N}$ excreted in housing that is retained in manure and available for application to land..

The effects of manure treatment technologies on emissions from the manure management chain in EU-27 were assessed through scenario analyses in Chapter 5. The implementation level (20\% of total manure production in housings) was assumed to be uniform for all scenarios; the level corresponds to the level currently achieved by forerunner countries for a specific technology. All treatment technologies have certain advantages and disadvantages. Slurry acidification appears to be the most promising technology for mitigating both $\mathrm{NH}_{3}$ and GHG emissions, followed by thermal drying, incineration and pyrolysis (Table 7-2). Acidification is also relatively cheap (Foged et al., 2011a; see Section 7.7). However, there are concerns related to the use of strong acids (e.g. $\mathrm{H}_{2} \mathrm{SO}_{4}, \mathrm{HCl}$ ) (Fangueiro et al., 2015). Acidifying slurry with $\mathrm{H}_{2} \mathrm{SO}_{4}$ may increase hydrogen sulfide $\left(\mathrm{H}_{2} \mathrm{~S}\right)$ emissions, which is highly toxic (Dai \& Blanes-Vidal, 2013). Minimizing $\mathrm{H}_{2} \mathrm{~S}$ emissions requires the aeration (oxygenation) of the acidified slurry, which is energy-intensive (Jensen, 2002). Composting and nitrification-denitrification treatment technologies may enhance $\mathrm{N}_{2} \mathrm{O}$ emissions significantly, depending on environmental conditions. Anaerobic digestion is effective for GHG mitigation, but does require gas-tight covering of storage facilities to minimize $\mathrm{NH}_{3}$ emissions and the recovery of residual biogas from stored digestate (Gioelli et al., 2011; 
Battini et al., 2014). Acidifying the digested slurry before storage can also decrease $\mathrm{NH}_{3}$ and GHG emissions significantly (Regueiro et al., 2016). Hence, combination of techniques may minimize unwanted side-effects. Biogas production can also reduce $\mathrm{CO}_{2}$ emissions due to the replacement of heat and electricity produced from fossil fuels, which was not examined in my thesis. Based on an additional analysis, the avoided $\mathrm{CO}_{2}$ emissions from coals may amount to 7.6-12.1 $\mathrm{Tg} \mathrm{CO}_{2}$-eq in the scenario with anaerobic digestion of $20 \%$ of total manure production. This is equivalent to $9-14 \%$ of non- $\mathrm{CO}_{2}$ GHG emissions from the manure management chain in EU-27 in 2010 (see discussion in Chapter 5).

\subsection{Nutrient recovery}

The estimated total feed $\mathrm{N}$ and $\mathrm{P}$ intake by all animal categories in EU-27 in 2010 was 12.2 $\mathrm{Tg} \mathrm{N}$ and $1.92 \mathrm{Tg} \mathrm{P}$, respectively (Chapters 3 and 5). The fractions of $\mathrm{N}$ and $\mathrm{P}$ in animal feed retained in animal products (liveweight gains, eggs, milk) were on average 21 and 24\%, respectively, and the fractions excreted via urine and faeces were on average $79 \%$ and $76 \%$, respectively (Table 7-3). The $\mathrm{N}$ recovery, the amounts of $\mathrm{N}$ in manures that were applied to and deposited on pastures, expressed as percent of the total $\mathrm{N}$ excretion, varied from 53 to $78 \%$ between countries (Table 7-3). The remaining $\mathrm{N}$ fraction was lost during manure storage and application/deposition to agricultural land or was exported to other countries. Differences between countries in $\mathrm{N}$ recovery are related to differences in animal categories and productivity, manure management systems and implementation of mitigation measures.

Grazing systems have relatively high $\mathrm{N}$ recovery and low $\mathrm{N}$ losses when compared with landless, industrial animal systems. Urine excreted by grazing animals typically infiltrates into the soil before substantial $\mathrm{NH}_{3}$ emissions can occur and overall $\mathrm{NH}_{3}$ emissions per animal are therefore less for grazing animals than for housed animals. This explains why the total $\mathrm{N}$ recovery from animal manure is relatively high in Ireland and UK (78\%, Table 7-3). Grazing animals account for $91 \%$ in Ireland and $78 \%$ in UK of the total number of animal (expressed in livestock units), while the average for the EU-27 is 57\% (Eurostat, 2016). Increasing grazing time of cattle has been recommended as measure to mitigate $\mathrm{NH}_{3}$ emissions and the recovery of $\mathrm{N}$ (Bittman et al., 2014). The potential to increase grazing depends on soil type, topography, farm size and structure (distances), climatic conditions, etc. (Bittman et al., 2014). Though the $\mathrm{N}$ recovery from the excreta from grazing animals is high, the effectiveness of $\mathrm{N}$ in dung and urine from grazing animals to fertilize pastures is low (Webb et al., 2013). This is related to the spatially uneven distribution of the dung and urine patches and the poor 


\section{Chapter 7}

synchrony of the deposition relative to herbage $\mathrm{N}$ demand in temperate climates. Hence, a significant fraction of the $\mathrm{N}$ from dung and urine is lost via $\mathrm{NO}_{3}$ leaching and denitrification (e.g. Ryden et al., 1984; De Klein \& Van Logtestijn, 1994; Oenema et al., 2008).

Table 7-3. The recovery of $\mathrm{N}$ and $\mathrm{P}$ at different stages of the manure management chain, from feed intake to manure applied to or deposited on land in EU-27 at country level in 2010 (derived from Chapters 3 and 5).

\begin{tabular}{|c|c|c|c|c|c|c|}
\hline \multirow{3}{*}{ Country } & \multicolumn{6}{|c|}{$\mathrm{N}$ and $\mathrm{P}$ recoveries at different stages of the manure management chain $(\%)$} \\
\hline & \multicolumn{2}{|c|}{ Feed to excretion } & \multicolumn{2}{|c|}{ Excretion to manure applied to land } & \multicolumn{2}{|c|}{ Feed to manure applied to lanc } \\
\hline & $\mathrm{N}$ & $\mathrm{P}$ & $\mathrm{N}$ & $\mathrm{P}$ & $\mathrm{N}$ & $\mathrm{P}$ \\
\hline Austria & 78 & 74 & 62 & 98 & 48 & 73 \\
\hline Belgium* & 73 & 70 & 71 & 96 & 52 & 68 \\
\hline Bulgaria & 81 & 82 & 64 & 98 & 52 & 80 \\
\hline Cyprus & 76 & 76 & 56 & 97 & 43 & 74 \\
\hline Czech & 77 & 76 & 60 & 98 & 46 & 74 \\
\hline Denmark & 73 & 73 & 70 & 99 & 51 & 72 \\
\hline Estonia & 79 & 75 & 66 & 98 & 52 & 74 \\
\hline Finland & 74 & 73 & 67 & 99 & 50 & 73 \\
\hline France* & 83 & 79 & 72 & 99 & 60 & 79 \\
\hline Germany* & 73 & 70 & 66 & 102 & 48 & 72 \\
\hline Greece & 82 & 82 & 78 & 99 & 64 & 81 \\
\hline Hungary & 73 & 75 & 56 & 97 & 41 & 73 \\
\hline Ireland & 88 & 82 & 78 & 99 & 68 & 82 \\
\hline Italy & 80 & 76 & 60 & 98 & 48 & 74 \\
\hline Latvia & 83 & 80 & 65 & 98 & 54 & 78 \\
\hline Lithuania & 81 & 79 & 66 & 98 & 53 & 77 \\
\hline Luxembourg & 84 & 80 & 73 & 99 & 62 & 80 \\
\hline Malta & 76 & 82 & 53 & 97 & 40 & 80 \\
\hline Netherlands* & 76 & 73 & 65 & 91 & 49 & 66 \\
\hline Poland & 75 & 74 & 56 & 97 & 42 & 72 \\
\hline Portugal & 81 & 77 & 73 & 98 & 59 & 76 \\
\hline Romania & 84 & 83 & 70 & 98 & 59 & 82 \\
\hline Slovakia & 81 & 80 & 59 & 97 & 48 & 78 \\
\hline Slovenia & 79 & 76 & 61 & 98 & 48 & 75 \\
\hline Spain & 79 & 77 & 71 & 98 & 56 & 76 \\
\hline Sweden & 82 & 77 & 69 & 99 & 57 & 76 \\
\hline UK & 84 & 80 & 78 & 99 & 65 & 79 \\
\hline EU-27 & 79 & 76 & 69 & 98 & 54 & 74 \\
\hline
\end{tabular}

*The across-border transport of manure was considered for these countries. For importing countries, the amount of manure applied to land includes the imported manure, for exporting countries, the amount of manure applied to land excludes the exported manure.

Ammonia emission mitigation measures increase the $\mathrm{N}$ recovery fraction from the animal excreta collected in housing systems. The implementation of these measures in practice varies between countries. In 2010, nearly all animal farms in Belgium, Denmark and the Netherlands have covered manure storage facilities; therefore the potential to further increase the $\mathrm{N}$ recovery through covered storages is limited in these countries. The average recovery of $\mathrm{N}$ and $\mathrm{P}$ from animal manure in the EU-27 is relative high compared to those of for example China and United States. The recovery fraction was only $25 \%$ for $\mathrm{N}$ and $45 \%$ for $\mathrm{P}$ in China in 2010 (Ma et al., 2010; Hou et al., 2013); mitigation measures are not applied and massive amounts of manures are discharged into evaporation ponds and rivers (Wang et al., 2010; Bai 
et al., 2014). The recovery from manure was $30-40 \%$ for $\mathrm{N}$ and $70-95 \%$ for $\mathrm{P}$ on commercial dairy farms in United States (Spears et al., 2003a, 2003b).

The estimated P recovery from manure is relatively high in EU-27 (Table 7-3). This is related to the obligatory leak-tight storage of manures (Nitrates Directive) and the estimated low $\mathrm{P}$ losses. Also manure discharges to surface waters are forbidden and grazing animals are not allowed to drop excreta in streams in EU-27. The P losses from manure storages via leaching and surface run-off range from 0 to $10 \%$ for EU countries, depending on storage conditions (Velthof et al., 2009). The uncertainty in these $\mathrm{P}$ loss fractions is relatively high because very few experimental studies have been conducted to measure P losses from manure storages in practice (Radcliffe et al., 2009).

\subsection{Barriers to the implementation of mitigation measures and manure treatment}

To increase the understanding related to the factors that affect the adoption of treatment technologies in practice, a stakeholder survey was conducted in Denmark, Italy, the Netherlands and Spain (Chapter 6). These four countries together shared about $55 \%$ of the total GHG mitigation achieved by manure treatment in the EU in 2010 (Chapter 5). Results from the survey indicate that the implementation of treatment technologies in practice is hindered by financial barriers such as high capital and operational cost.

Technologies such as solid-liquid mechanical separation, slurry acidification and composting of solid manure are generally considered to be less complex in operation and relatively low cost. Thus, these technologies are suitable for farm-scale operations (Chapter 6). Costs of treating slurry with a mechanical screen separator or with a decanting centrifuge were estimated at $€ 0.15$ to $€ 0.8$ per $\mathrm{kg} \mathrm{N}$ in effluent, including the power costs, maintenance costs and the capital costs of the equipment (Møller et al., 2000). Slurry acidification has a net cost of $€ 0.14$ per $\mathrm{kg} \mathrm{N}$ in effluent (or $€ 0.21$, without subsides), according to a case study in Denmark (Foged et al., 2011). In comparison, nitrification-denitrification treatment and anaerobic digestion have relatively high economic costs, and are most suitable for farm cooperatives or at industrial scale. Case studies indicate that the cost of nitrificationdenitrification treatment was $€ 1$ to $€ 1.2$ per $\mathrm{kg} \mathrm{N}$ in effluent for a plant in Spain, and about $€ 2$ to $€ 2.5$ per $\mathrm{kg} \mathrm{N}$ in effluent for a plant in the Netherlands (Melse \& Verdoes, 2005; Foged et al., 2011). The net cost of anaerobic mono-digestion was estimated at $€ 2.3$ to $€ 3 \mathrm{~kg}$ per $\mathrm{N}$ in the effluent for a biogas plant in Denmark. Co-digestion of manure with other substrates can increase the yield of biogas, and thus may lead to a decrease in cost (Foged et al., 2011). 


\section{Chapter 7}

Several assessments have indicated that subsidies are necessary for the successful adoption of anaerobic digestion, when the price of fossil energy remains as low as during the period 20102016 (Chinese et al., 2014; CDM, 2015; Chapter 6). Installation of an incineration plant requires a vast investment and also requires subsidies in order to make it economically feasible. The poultry incineration plant in the Netherlands relies on the MEP (Environmental Quality of Electricity Production) subsidy of more than €20 million per year. In addition, there are economic returns from sales of electricity, ash (PK-fertilizer), and from a gate fee for the poultry manure. This gate fee ranges from $€ 4$ to $€ 21$ per ton of poultry manure, depending on the quality of the manure, the distance to the plant and the duration of the contract.

Table 7-4. Ammonia emission abatement measures and estimated costs for farmers in Europe and North America (summarized from the UNECE guidance document; Bittman et al., 2014).

\begin{tabular}{llc}
\hline Abatement measures & Management stages & \multicolumn{2}{c}{$\begin{array}{c}\text { Cost }\left(€ / \mathrm{kg} \mathrm{NH}_{3}-\mathrm{N}\right. \\
\text { reduced })^{\mathrm{b}}\end{array}$} \\
\hline Low-protein feeding & & $-2.0-2.0$ \\
Covered storages & whole chain & $1.0-2.5$ \\
-tight lid, tent structure & & $0.5-1.3$ \\
-plastic cover & slurry storage & $0.3-5.0$ \\
-floating cover & slurry storage & - \\
-straw cover & slurry storage & \\
Low-emission application & slurry storage & $-0.5-1.5$ \\
-trailing hose & application to land & $-0.5-1.5$ \\
-trailing shoe & & $-0.5-1.5$ \\
-injection, open slot & arable land/grassland & $-0.5-1.2$ \\
-injection, closed slot & grassland & \\
-Incorporation of surface applied slurry & arable land/grassland & $-0.5-1.0$ \\
(immediately by ploughing) & arable land & $-0.5-1.0$ \\
(within 4 hours) & & $-0.5-2.0$ \\
(within 24 hours) & & \\
-Incorporation of surface applied solid & arable land & \\
manure & & $-0.5-1.0$ \\
(immediately by ploughing) & & $0.5-1.5$ \\
(within 4 hours) & & $0.5-2.0$ \\
(within 12-24 hours) & &
\end{tabular}

a a decrease of $1 \%$ in protein content in feed (absolute value).

${ }^{\mathrm{b}}$ negative costs indicate net gains, mainly through feed savings (low-protein feeding measures) or fertilizer $\mathrm{N}$ savings (low-emission application measures).

Implementation of $\mathrm{NH}_{3}$ emission abatement measures and manure treatment increases the cost of livestock farming, and may have significant effects on farmers' income (Oenema et al., 2009). Because of the perceived high costs, farmers may be reluctant to implement these measures, which in part contributes to the variable and slow responses of Member States to environmental policies in agriculture (Oenema et al., 2011). Economic costs and costeffectiveness of abatement measures are the key factor affecting farmers' decisions. Costs of 
$\mathrm{NH}_{3}$ emission abatement measures at different stages of the manure management chain are summarized in Table 7-4.

The cost of diet manipulations depend on the initial animal feed composition and on the market prices of feed ingredients and synthetic amino acids (Bittman et al., 2014; Reis et al., 2015). Low-N animal feeding is mostly applicable to housed animals and less to grasslandbased systems with grazing animals. In EU-27, about $65 \%$ of $\mathrm{N}$ excretion is currently produced in animal houses, and 35\% is from grazing animals in pastures (Chapter 5). The costs of low-emission manure application technologies are related to investment, depreciation and maintenance costs (spreader, use of heavier tractor), labor costs (increased labor time), and the size of the farm area. The additional costs of low-emission application are partially outweighed by the financial benefits of higher yields and yield consistency, reduced mineral fertilizer requirements, and by a reduction of odor and crop contamination (Webb et al., 2006; Bittman et al., 2014).

\subsection{Some concluding remarks}

Scientific research on manure and manure treatment started more than a century ago (e.g. Kolenbrander and De la Lande Cremer, 1967; Russell, 1978). For a long time, the research was focused on its fertilizing and soil quality improvement values. Bussink and Oenema (1998) reviewed that possible $\mathrm{NH}_{3}$ losses from manures have been known since early $19^{\text {th }}$ century, while the full environmental impacts of $\mathrm{N}$ losses from animal manure have been examined seriously only from the 1980s. Emission mitigation measures have been implemented in practice from the 1990s, while the idea of a manure management chain approach was developed from the 2000s (e.g. Velthof et al., 2009).

My $\mathrm{PhD}$ thesis research has been built on a long history of research. The most novel aspects of my $\mathrm{PhD}$ thesis research are

- The consistent application of a manure management chain approach, which allows a coherent analysis and estimation of the effects (including side-effects) introduced through interventions in this chain,

- A systematic comparison of methodologies used for the estimation of manure $\mathrm{N}$ production per animal category in EU-countries,

- The development of a harmonized and transparent methodology for the estimation of manure $\mathrm{N}$ and $\mathrm{P}$ production at country and EU levels, 


\section{Chapter 7}

- A systematic analysis of the effects of the main $\mathrm{NH}_{3}$ emission mitigation measures on $\mathrm{NH}_{3}$ and $\mathrm{GHG}$ emissions,

- A systematic analysis of the effects of the main manure treatment technologies on nutrient recovery and gaseous emissions,

- A survey on stakeholder perceptions related to manure treatment technologies,

- An integrated assessment of emission mitigation measures and manure treatment techniques at national level and EU level.

The findings reported in this thesis are important for scientists, policy makers, industry, extension services, as well as farmers and farmers' organizations. The amounts of $\mathrm{N}$ and $\mathrm{P}$ in animal manures produced annually are large in the EU-27 (similar to the amounts of fertilizer $\mathrm{N}$ and $\mathrm{P}$ used annually), while emissions of $\mathrm{NH}_{3}, \mathrm{~N}_{2} \mathrm{O}$ and $\mathrm{CH}_{4}$, and $\mathrm{N}$ and $\mathrm{P}$ losses from the whole manure management chain have significant environmental impacts. Various emission mitigation measures and manure treatment techniques exist, but the effectiveness and costs of these measures and techniques vary greatly. The implementation of measures and techniques will not happen overnight; they require incentives, guidance and cooperation.

\subsection{Recommendations for future research}

My research has identified also a number of topics that would benefit from further studies.

- Country and regional specific $\mathrm{NH}_{3}$ and $\mathrm{GHG}$ emission factors for manure treatment techniques, considering also possible temporal (seasonal) variations in emissions.

- Quantification of the $\mathrm{N}$ and $\mathrm{P}$ fertilizer replacement values of manure treatment products for different crops.

- Quantification of P losses from manure storages and manure treatment techniques across EU-27.

- Further investigating barriers to the implementation of emission mitigation measures and manure treatment technologies in different countries, including those that have (e.g. Germany, Belgium, Netherlands, and UK) and do not have much experiences with these measures and technologies.

- Further development of treatment technologies that minimize unwanted side-effects and lower the cost (through increases in energy efficiency, and maximizing the mitigation potential). In the ReUseWaste research project, improved approaches for 
manure treatment have been developed for manure separation, energy recovery, emission mitigation during manure storage and field application, which may increase the fertilizer value of manure products (see http://www.reusewaste.eu/). Further validation of these improved technologies and products in pilot and commercial scales are needed. The results of these additional tests will contribute also to improving the MITERRA-Europe model used for integrated assessments at national and EU levels. 


\section{References}

Asman WAH, Klimont Z, Brink C (2011) A simplified model of nitrogen flows from manure management. IIASA Interim Report IR-11-030. International Institute for Applied Systems Analysis (IIASA), Laxenburg, Austria.

Bai ZH, Ma L, Qin W, Chen Q, Oenema O, Zhang FS (2014) Changes in pig production in China and their effects on nitrogen and phosphorus use and losses. Environmental science \& technology, 48, 12742-12749.

Battini F, Agostini a., Boulamanti a. K, Giuntoli J, Amaducci S (2014) Mitigating the environmental impacts of milk production via anaerobic digestion of manure: Case study of a dairy farm in the Po Valley. Science of the Total Environment, 481, 196-208.

Bittman S, Dedina M, Howard C, Oenema O, Sutton M (2014) Options for Ammonia Mitigation: Guidance from the UNECE Task Force on Reactive Nitrogen. Centre for Ecology and Hydrology, Edinburgh, UK.

Britz W, Witzke H-P (2012) CAPRI model documentation 2012 :Version 2012. Institute for Food and Resource Economics, University of Bonn, Bonn.

Bussink DW, Oenema O (1998) Ammonia volatilization from dairy farming systems in temperate areas: A review. Nutrient Cycling in Agroecosystems, 51, 19-33.

CBS (2012) Standardised calculation methods for animal manure and nutrients: Standard data 19902008. Statistics Netherlands, The Hague, 82 pp.

CDM, 2015. Co-digestion of manure and organic residues in the Netherlands (in Dutch: Nut en risico's van covergisting; Syntheserapport). Commissie Deskundigen Meststoffenwet, Wettelijke Onderzoekstaken Natuur \& Milieu, Wageningen University, Wageningen, 147 pages.

Chinese D, Patrizio P, Nardin G (2014) Effects of changes in Italian bioenergy promotion schemes for agricultural biogas projects: Insights from a regional optimization model. Energy Policy, 75, 189-205.

Dai XR, Blanes-Vidal V (2013) Emissions of ammonia, carbon dioxide, and hydrogen sulfide from swine wastewater during and after acidification treatment: effect of $\mathrm{pH}$, mixing and aeration. Journal of environmental management, 115, 147-54.

De Klein CAM, Van Logtestijn RSP (1994) Denitrification in the top-soil of managed grasslands in the Netherlands in relation tot soil type and fertilizer level. Plant and Soil, 163, 33-44.

EEA (2014) European Union emission inventory report 1990-2012 under the UNECE Convention on Long-range Transboundary Air Pollution (LRTAP). $130 \mathrm{pp.}$

Eshel G, Shepon A, Makov T, Milo R (2014a) Partitioning United States' Feed Consumption Among Livestock Categories For Improved Environmental Cost Assessments. Journal of Agricultural Science, In press, 1-14.

Eshel G, Shepon A, Makov T, Milo R (2014b) Land, irrigation water, greenhouse gas, and reactive nitrogen burdens of meat, eggs, and dairy production in the United States. Proceedings of the National Academy of Sciences, 111, 11996-12001.

Fangueiro D, Hjorth M, Gioelli F (2015) Acidification of animal slurry- a review. Journal of Environmental Management, 149, 46-56.

Fernandez-Lopez M, Puig-Gamero M, Lopez-Gonzalez D, Avalos-Ramirez A, Valverde J, SanchezSilva L (2015) Life cycle assessment of swine and dairy manure: Pyrolysis and combustion processes. Bioresource Technology, 182, 184-192.

Foged HL, Flotats X, Blasi AB, Schelde KM, Palatsi J, Magri A, Juznik. Z (2011) Assessment of economic feasibility and environmental performance of manure processing technologies. Technical Report No. IV to the European Commission, Directorate-General Environment. 130 pp. 
Gac A, Beline F, Bioteau T, Maguet K (2007) A French inventory of gaseous emissions $\left(\mathrm{CH}_{4}, \mathrm{~N}_{2} \mathrm{O}\right.$, $\mathrm{NH}_{3}$ ) from livestock manure management using a mass-flow approach. Livestock Science, 112, 252-260.

Galloway JN, Winiwarter W, Leip A, Leach AM, Bleeker A, Erisman JW (2014) Nitrogen footprints: past, present and future. Environmental Research Letters, 9, 115003.

Gioelli F, Dinuccio E, Balsari P (2011) Residual biogas potential from the storage tanks of nonseparated digestate and digested liquid fraction. Bioresource technology, 102, 48-51.

Hamelin L, Wesnæs M, Wenzel H, Petersen BM (2011) Environmental consequences of future biogas technologies based on separated slurry. Environmental science \& technology, 45, 5869-5877.

Hou Y, Ma L, Gao ZL, Wang FH, Sims JT, Ma WQ, Zhang FS (2013) The Driving Forces for Nitrogen and Phosphorus Flows in the Food Chain of China, 1980 to 2010. Journal of Environment Quality, 42, 962.

Hutchings NJ, Sommer SG, Andersen JM, Asman WAH (2001) A detailed ammonia emission inventory for Denmark. 35.

Hyde BP, Carton OT, O’Toole P, Misselbrook TH (2003) A new inventory of ammonia emissions from Irish agriculture. Atmospheric Environment, 37, 55-62.

Jensen АØ (2002) Changing the environment in swine buildings using sulfuric acid. Transactions of the American Society of Agricultural Engineers, 45, 223-227.

Kolenbrander GJ and LCN De la Lande Cremer (1967) Stalmest en Gier. Waarde en mogelijkheden. Veenman \& Zonen, Wageningen.

Kupper T, Bonjour C, Menzi H (2015) Evolution of farm and manure management and their in $\mathrm{fl}$ uence on ammonia emissions from agriculture in Switzerland between 1990 and 2010. Atmospheric Environment, 103, 215-221.

Leip A, Billen G, Garnier J et al. (2015) Impacts of European livestock production: nitrogen, sulphur, phosphorus and greenhouse gas emissions, land-use, water eutrophication and biodiversity. Environmental Research Letters, 10, 115004.

Lesschen JP, van den Berg M, Westhoek HJ, Witzke HP, Oenema O (2011) Greenhouse gas emission profiles of European livestock sectors. Animal Feed Science and Technology, 166-167, 16-28.

Ma L, Ma WQ, Velthof GL, Wang FH, Qin W, Zhang FS, Oenema O (2010) Modeling Nutrient Flows in the Food Chain of China. Journal of Environment Quality, 39, 1279-1289.

Ma L, Wang F, Zhang W et al. (2013) Environmental assessment of management options for nutrient flows in the food chain in China. Environmental Science and Technology, 47, 7260-7268.

Melse RW, Verdoes N (2005) Evaluation of Four Farm-scale Systems for the Treatment of Liquid Pig Manure. Biosystems Engineering, 92, 47-57.

Mezzullo WG, McManus MC, Hammond GP (2012) Life cycle assessment of a small-scale anaerobic digestion plant from cattle waste. Applied Energy, 102, 657-664.

Møller H, Lund I, Sommer S (2000) Solid-liquid separation of livestock slurry: efficiency and cost. Bioresource Technology, 74, 223-229.

Oenema O, Bannink A, Somme, SG, Groenigen JWV, Velthof GL (2008) Gaseous Nitrogen Emissions from Livestock Farming Systems. In: Nitrogen in the environment sources, problems, and management / Hatfield, J.L., Follett, R.F., Londen, U.K. : Elsevier, p. 395 - 441.

Oenema O, Witzke HP, Klimont Z, Lesschen JP, Velthof GL (2009) Integrated assessment of promising measures to decrease nitrogen losses from agriculture in EU-27. Agriculture, Ecosystems \& Environment, 133, 280-288.

Oenema O, Bleeker A, Braathen NA et al. (2011) Nitrogen in current European policies. In: The European nitrogen assess ment (eds Sutton MA, Howard CM, Erisman JW, Billen G, Bleeker A, Grennfelt P, Grinsven H van, Grizzetti B), pp. 62-81. Cambridge University Press, Cambridge, 
UK.

Petersen S, Sommer S, Beline F et al. (2007) Recycling of livestock manure in a whole-farm perspective. Livestock Science, 112, 180-191.

Radcliffe DE, Freer J, Schoumans O (2009) Diffuse phosphorus models in the United States and europe: their usages, scales, and uncertainties. Journal of Environment Quality, 38, 1956-1967.

Regueiro I, Coutinho J, Gioelli F, Balsari P, Dinuccio E, Fangueiro D (2016) Acidification of raw and co-digested pig slurries with alum before mechanical separation reduces gaseous emission during storage of solid and liquid fractions. Agriculture, Ecosystems \& Environment, 227, 42-51.

Reidy B, Rhim B, Menzi H (2008) A new Swiss inventory of ammonia emissions from agriculture based on a survey on farm and manure management and farm-specific model calculations. Atmospheric Environment, 42, 3266-3276.

Reis S, Howard C, Sutton MA (2015) Costs of Ammonia Abatement and the Climate Co-Benefits (eds Reis S, Howard C, Sutton MA). Springer Netherlands, Dordrecht, 292 pp.

Russell EW 1978 Soil Conditions and Plant Growth. 10th edition. Longman, London.

Ryden JC, Ball PR, Garwood EA (1984) Nitrate leaching from grassland. Nature, 311, 50-53.

Sandars DL, Audsley E, Cañete C, Cumby TR, Scotford IM, Williams A.G (2003) Environmental Benefits of Livestock Manure Management Practices and Technology by Life Cycle Assessment. Biosystems Engineering, 84, 267-281.

Schröder JJ, Aarts HFM, van Middelkoop JC, Schils RLM, Velthof GL, Fraters B, Willems WJ (2007) Permissible manure and fertilizer use in dairy farming systems on sandy soils in The Netherlands to comply with the Nitrates Directive target. European Journal of Agronomy, 27, 102-114.

Sommer SG, Olesen JE, Petersen SO, Weisbjerg MR, Valli L, Rohde L, Béline F (2009) Regionspecific assessment of greenhouse gas mitigation with different manure management strategies in four agroecological zones. Global Change Biology, 15, 2825-2837.

Spears RA, Kohn R., Young AJ (2003a) Whole-Farm Nitrogen Balance on Western Dairy Farms. Journal of Dairy Science, 86, 4178-4186.

Spears RA, Kohn R., Young AJ (2003b) Whole-Farm Phosphorus Balance on Western Dairy Farms. Journal of Dairy Science, 86, 688-695.

ten Hoeve M, Hutchings NJ, Peters GM, Svanström M, Jensen LS, Bruun S (2014) Life cycle assessment of pig slurry treatment technologies for nutrient redistribution in Denmark. Journal of environmental management, 132, 60-70.

Tilman D, Clark M (2014) Global diets link environmental sustainability and human health. Nature, $515,518-522$.

Velthof GL, Oudendag D, Witzke HP, Asman W a H, Klimont Z, Oenema O (2009) Integrated assessment of nitrogen losses from agriculture in EU-27 using MITERRA-EUROPE. Journal of environmental quality, 38, 402-417.

Velthof GL, van Bruggen C, Groenestein CM, de Haan BJ, Hoogeveen MW, Huijsmans JFM (2012) A model for inventory of ammonia emissions from agriculture in the Netherlands. Atmospheric Environment, 46, 248-255.

De Vries JW, Vinken TMWJ, Hamelin L, De Boer IJM (2012) Comparing environmental consequences of anaerobic mono- and co-digestion of pig manure to produce bio-energy--a life cycle perspective. Bioresource technology, 125, 239-248.

Wang F, Dou Z, Ma L, Ma W, Sims JT, Zhang F (2010) Nitrogen Mass Flow in China's Animal Production System and Environmental Implications. Journal of Environment Quality, 39, 1537.

Webb J, Misselbrook TH (2004) A mass-flow model of ammonia emissions from UK livestock production. Atmospheric Environment, 38, 2163-2176.

Webb J, Ryan M, Anthony S, Brewer a, Laws J, Aller M, Misselbrook T (2006) Cost-effective means 
of reducing ammonia emissions from UK agriculture using the NARSES model. Atmospheric Environment, 40, 7222-7233.

Webb J, Sørensen P, Velthof G et al. (2013) An Assessment of the Variation of Manure Nitrogen Efficiency throughout Europe and an Appraisal of Means to Increase Manure-N Efficiency. In: Advances in Agronomy, Vol. 119, pp. 371-442. Elsevier. 

SUMMARY 


\section{Summary}

Animal manures are major sources of nutrients and organic matter, to be used to fertilize crops and improve soil quality. However, when not properly managed, these manures release considerable amounts of ammonia $\left(\mathrm{NH}_{3}\right)$, nitrous oxide $\left(\mathrm{N}_{2} \mathrm{O}\right)$ and methane $\left(\mathrm{CH}_{4}\right)$ into the air, and nitrogen $(\mathrm{N})$ and phosphorus $(\mathrm{P})$ to water bodies, which create a range of unwanted environment impacts. Emissions of $\mathrm{NH}_{3}$ contribute to the acidification and eutrophication of nitrogen-limited ecosystems, and can have negative effects on human health. Emissions of $\mathrm{N}_{2} \mathrm{O}$ and $\mathrm{CH}_{4}$ contribute considerably to the radiative forcing; the global warming potentials of $\mathrm{N}_{2} \mathrm{O}$ and $\mathrm{CH}_{4}$ are 298 and 25 times higher, respectively, than that of $\mathrm{CO}_{2}$ per $\mathrm{kg}$. Approximately $40 \%$ of the global anthropogenic $\mathrm{NH}_{3}$ and $\mathrm{N}_{2} \mathrm{O}$ emissions and about $10 \%$ of the global anthropogenic $\mathrm{CH}_{4}$ emissions are associated with animal manures. $\mathrm{N}$ and $\mathrm{P}$ losses from manure decrease also its fertilization value.

Emissions of $\mathrm{NH}_{3}, \mathrm{CH}_{4}$ and $\mathrm{N}_{2} \mathrm{O}$ to air and leaching losses of $\mathrm{N}$ and $\mathrm{P}$ to water bodies from manure depend on the management activities and techniques used at different stages of the whole manure management chain, from animal feeding up to manure application to land. A large number of emission mitigation measures and manure treatment technologies have been developed during the last decades, and part of these have been implemented in practice in Europe. Introducing a measure or technology to mitigate emissions from one source may affect emissions downstream in the chain (so-called 'pollution swapping'), or emissions of other pollutants. The trade-offs and co-benefits of emission mitigation measures and manure treatment technologies are as yet poorly understood, especially when taking the whole manure management chain into account. Moreover, the effects of combinations of measures and technologies have not been well analyzed, and analyses at national scales are lacking.

The overall objective of this $\mathrm{PhD}$ thesis research is (i) to enhance the quantitative insight into the effects of emission mitigation measures and treatment technologies on emissions of $\mathrm{NH}_{3}$, $\mathrm{N}_{2} \mathrm{O}$ and $\mathrm{CH}_{4}$, and the recovery of $\mathrm{N}$ and $\mathrm{P}$ from animal manure in the whole chain from animal feeding to manure application to land, and (ii) to explore the effects of combinations of measures and technologies to mitigate these emissions and to increase the $\mathrm{N}$ and $\mathrm{P}$ recovery. The research was part of the Marie Curie Training Program ReUseWaste (Recovery and Use of Nutrients, Energy and Organic Matter from Animal Waste). In total eleven PhD students and two post docs have been working on various specific mitigation measures and treatment technologies. The research reported in this thesis focused on the integral analysis of 
the whole manure management chain, and on the up-scaling and synthesis of research results, including those from literature. This thesis has 5 research chapters, next to a general introduction (Chapter 1) and a general discussion (Chapter 7)

In Chapter 2, methodologies for estimating $\mathrm{N}$ excretion factors for the main animal categories in member states of the European Union (EU) were reviewed. The review included the guidelines and methodologies suggested by the EU Nitrates Directive, the OECD/Eurostat gross $\mathrm{N}$ balance guidebook, the EMEP/EEA Guidebook and the IPCC Guidelines. In addition, approaches used in modeling studies were reviewed. Nitrogen excretion factors (or coefficients) are defined as the total amount of $\mathrm{N}$ excreted by a well-defined livestock category per year via urine and faeces. Results show that $\mathrm{N}$ excretion factors for dairy cattle, other cattle, pigs, laying hens, broilers, sheep, and goats differ significantly between countries and also within countries between policy reports. Part of these differences may be related to differences in animal breeds and animal productivity, size/weight of the animals, and feed composition. Another part of the differences in $\mathrm{N}$ excretion factors is related to differences in methodologies and the aggregation of livestock categories. The methodologies and data used by member states are often not well described. It is concluded that there is a need for a common, harmonized methodology and procedure for the estimation of $\mathrm{N}$ excretion factors, to arrive at a common basis for the estimation of the production of manure $\mathrm{N}$, and for the estimation of $\mathrm{N}$ balances and emissions of $\mathrm{NH}_{3}$ and $\mathrm{N}_{2} \mathrm{O}$ across the EU.

In Chapter 3, a transparent and uniform methodology for estimating annual feed use and $\mathrm{N}$ excretion per animal category for all countries of the EU-27 was developed, based on the energy and protein requirements of the animals and statistics of feed use and composition, animal number and productivity. The calculated total feed use in the EU-27 was 506 Tg dry mass in 2010. Dairy cows used 29\%, other cattle 34\%, pigs $17 \%$, chicken $9 \%$, sheep and goats $8 \%$, and other animal categories $3 \%$ of the total feed use. Grass and annual forages were mainly used by dairy cows (30 and 49\%, respectively) and other cattle (55 and 44\%); pigs used most of the feed cereals (53\%); protein-rich feed (e.g., soybean meal) were mostly used by pigs $(34 \%)$ and chicken $(24 \%)$. Differences between countries in feed use were large, which are mainly related to variations in national feed supply and animal productivity. The calculated total $\mathrm{N}$ excretion of the animals amounted to $9.7 \mathrm{Tg}$ in 2010 , and varied between countries from 14 in Bulgaria to 291 in Netherlands $\mathrm{kg} \mathrm{N} \mathrm{ha}^{-1}$ of utilized agricultural land. The method developed in this Chapter addresses various key livestock categories 


\section{Summary}

simultaneously, using a uniform methodology and common national statistics, and provides national averages, which allow direct comparison of feed use and $\mathrm{N}$ excretion coefficients among countries.

In Chapter 4, firstly the impacts of a suite of $\mathrm{NH}_{3}$ mitigation measures on emissions of $\mathrm{NH}_{3}$, $\mathrm{N}_{2} \mathrm{O}$ and $\mathrm{CH}_{4}$ at individual stages of the manure management chain were analyzed by means of a meta-analysis of published data (derived from 126 published studies). Secondly, the overall impacts of alternative combinations of mitigation measures on $\mathrm{NH}_{3}, \mathrm{CH}_{4}$, and $\mathrm{N}_{2} \mathrm{O}$ emissions from the whole chain were evaluated through scenario analysis. Significant $\mathrm{NH}_{3}$ emission reduction was estimated for i) housing via lowering the dietary crude protein $(\mathrm{CP})$ content (emission reduction of $24-65 \%$, depending on the reduction rate of $\mathrm{CP}$ ), for ii) external slurry storages via acidification $(83 \%)$ and covers of straw $(78 \%)$ or artificial films (98\%), for iii) solid manure storages via compaction and covering (61\%, compared to composting), and for iv) manure application to land via band spreading (55\%, compared to surface application), via incorporation into the soil (70\%) and via injection into the soil (80\%). Acidification decreased $\mathrm{CH}_{4}$ emissions from stored slurry by $87 \%$. Significant increases in $\mathrm{N}_{2} \mathrm{O}$ emissions were found for straw-covered slurry storages (by two orders of magnitude) and manure injection (by 26-199\%). Compaction, static stockpiling and covering of solid manure tend to decrease $\mathrm{NH}_{3}$ emissions and increase $\mathrm{CH}_{4}$ and $\mathrm{N}_{2} \mathrm{O}$ emissions compared to manure heaps subjected to composting. However, the number of observations underlying these latter effects is low. Lowering the protein content of feed and acidifying slurry are strategies that consistently reduce $\mathrm{NH}_{3}$ and $\mathrm{GHG}$ emissions in the whole chain. Other strategies may reduce emissions of a specific gas or emissions source, by which there is a risk of unwanted trade-offs in the manure management chain. Proper combinations of mitigation measures at farm level are therefore important to minimize emissions of $\mathrm{NH}_{3}$ and GHG from animal manure.

Chapter 5 reports on an integrated assessment of the effects of manure treatment on $\mathrm{NH}_{3}, \mathrm{~N}_{2} \mathrm{O}$ and $\mathrm{CH}_{4}$ emissions from manure management chains in EU-27 at the national level for the year 2010, using the improved model MITERRA-Europe. Whole-chain effects of implementing twelve treatment technologies in EU-27 on emissions and nutrient ( $\mathrm{N}$ and P) recovery were further explored through scenario analyses; the level of implementation corresponded to levels currently achieved by forerunner countries (i.e. $20 \%$ of total manure production from housings for each technique). The scenario analyses included an uncertainty 
analysis. Results show that total $\mathrm{NH}_{3}$ emissions from the manure management chain in EU-27 were 2.5 Tg N and GHG emissions were $86.9 \mathrm{Tg} \mathrm{CO}_{2}$-eq in 2010 , with a relative uncertainty (coefficient of variation) of $16 \%$ and $20 \%$, respectively. Manure treatment decreased GHG emissions from 0 to $17 \%$ depending on country in 2010, with the largest reduction from anaerobic digestion (especially in Germany, Denmark and Italy). Manure treatment effects on $\mathrm{NH}_{3}$ emissions were small in 2010. Scenario analyses indicate that acidification, thermal drying, incineration and pyrolysis can consistently decrease both $\mathrm{NH}_{3}(9-11 \%)$ and GHG (11$18 \%$ ) emissions from the management chain of EU-27 (compared to the reference without manure treatment). Nitrification-denitrification treatment decreased $\mathrm{NH}_{3}$ emissions, but increased GHG emissions, due to increased $\mathrm{N}_{2} \mathrm{O}$ emissions. Composting had no significant effects on total emissions of $\mathrm{NH}_{3}$ and GHG from the chain. Anaerobic digestion decreased GHG emissions (19\%), but only marginally affected overall $\mathrm{NH}_{3}$ emissions. Combining anaerobic digestion with acidification (i.e. acidifying digested slurry) resulted in significant reductions in both $\mathrm{NH}_{3}$ and $\mathrm{GHG}$ emissions. The $\mathrm{N}$ recovery (\% of nitrogen excreted in animal housings that is applied to land) in EU-27 would increase from a mean of $57 \%$ (in 2010 ) to $61 \%$ in the acidification scenario, but would decrease to $48 \%$ in the incineration scenario and to $52 \%$ in the nitrification and denitrification treatment scenario. Other technologies (solid-liquid separation, anaerobic digestion, drying, composting etc.) only marginally affect the $\mathrm{N}$ recovery. The $\mathrm{P}$ recovery was estimated at $98 \%$ in 2010 , and was not significantly affected by the manure treatment scenarios.

Chapter 6 reports on a survey conducted under various stakeholder groups with expertise in the domain of manure treatment in four European countries (Denmark, Italy, the Netherlands and Spain) that have regions of high animal density. The survey addressed questions related to i) which factors facilitate and hinder the implementation of treatment technologies in practice, ii) which technologies have the most potential for successful adoption, and iii) how farm characteristics and the scale of the treatment operation affect priorities for adoption. Results show that pressure from governmental regulations was perceived as a key factor that stimulated manure treatment in all four countries (70\% of respondents). Processing manure to produce bioenergy was considered important in Denmark and Italy, but less important in Spain and the Netherlands. The major barriers to technology adoption were related to economic factors (lack of investment capital, high processing cost and a long payback time; $45-60 \%$ of respondents), while there was relatively little concern regarding transport, noise burden and health risk. Slurry separation and anaerobic digestion were perceived to have the 


\section{Summary}

greatest potential for a common adoption in practice in all four countries. Other preferred technologies were more country-specific (e.g. acidification in Denmark, composting in Spain, and drying and reverse osmosis in Netherlands), which is related to the differences between regions/nations in livestock densities and socio-economic, political and environmental conditions. Farm characteristics and scale of operation were identified as important factors that can influence the decision of farmers and investors for technology adoption.

The main conclusions of this $\mathrm{PhD}$ thesis are as follows:

- In EU-27, the amounts of $\mathrm{N}$ and $\mathrm{P}$ in manure are as large as or larger than the total amounts of fertilizer $\mathrm{N}$ and $\mathrm{P}$ used annually. However, there is a huge spatial variation in manure production. Nutrient excretion factors per animal category also vary between countries, as a result of variations in feed use and animal productivity. Clearly, for accurate inventories of national emission there is a need for estimating nutrient excretion using country-specific feed use data. There is a need for a common methodology and protocol for the estimation of $\mathrm{N}$ and $\mathrm{P}$ excretion factors per animal category, because some differences between countries in reported excretion factors were related to differences in methodology and aggregation/upscaling.

- Increasing the effectiveness of measures to mitigate $\mathrm{NH}_{3}$ and $\mathrm{GHG}$ emissions from animal manure requires proper combination of measures in the manure management chain. Lowering the dietary protein content in animal feed is an effective measure to reduce $\mathrm{NH}_{3}$ emissions and other $\mathrm{N}$ emissions at all stages of the manure management chain. Other measures may reduce emissions of a specific gas or emissions source, by which there is a risk of unwanted trade-offs in the manure management chain. Joint adoption of these measures with low-N feeding strategies and slurry acidification can greatly decrease the risk of pollution swapping.

- Implementation of manure treatment is on average still limited in EU-27. Effects of manure treatment on $\mathrm{NH}_{3}$ and $\mathrm{GHG}$ emissions are therefore relatively small at EU level. Increasing the implementation of treatment technologies, including acidification, incineration and thermal drying, or optimized combinations of treatment technologies, can significantly contribute to achieving $\mathrm{NH}_{3}$ and $\mathrm{GHG}$ emission targets of EU environmental policies.

- Implementation of manure treatment technologies provides opportunities to improve the use of plant nutrients in manures, because of the release of manure products with 
different N/P ratios. Applying acidification technology and optimized combination of $\mathrm{NH}_{3}$ emission mitigation measures increase the $\mathrm{N}$ recovery from animal manure, and can decrease the demand of mineral fertilizers. However, some technologies decrease the $\mathrm{N}$ and $\mathrm{P}$ recovery and/or decrease the availability of the $\mathrm{N}$ and $\mathrm{P}$ in manure products to plants.

- Implementation of manure treatment in practice is forced by the pressure from EU environmental regulations, and is hindered by financial barriers. To encourage the adoption of manure treatment, policies must be economically appealing to attract new adopters (farmers and industries). Long-term financial support schemes (e.g. subsidies) seem to be necessary, especially with the current low prices for fossil fuels. Outreach strategies are required to convey the knowledge to stakeholders from both the supply and the demand side, with respect to the economic, technical and environmental aspects of manure treatment technologies. 

SAMENVATTING 


\section{Samenvatting}

Dierlijk mest is een belangrijk bron van nutriënten en organisch materiaal. De mest dient om gewassen te bemesten en om de bodemkwaliteit te verbeteren. Echter, als mest niet goed wordt opgeslagen en/of behandeld, dan kunnen nutriënten en broeikasgassen naar het milieu lekken. Het gaat daarbij om de gasvormige verbindingen ammoniak $\left(\mathrm{NH}_{3}\right)$, lachgas $\left(\mathrm{N}_{2} \mathrm{O}\right)$ en methaan $\left(\mathrm{CH}_{4}\right)$ die naar de lucht kunnen ontsnappen, en om nutriënten die uit mestopslagen en na toediening op het land naar grondwater en oppervlaktewater kunnen uitspoelen. Deze emissies hebben een reeks van milieukundige effecten.

Emissies van $\mathrm{NH}_{3}$ leiden tot verzuring en eutrofiëring van stikstof-gelimiteerde ecosystemen. In de lucht heeft $\mathrm{NH}_{3}$ een negatief effect op de menselijke gezondheid. Lachgas $\left(\mathrm{N}_{2} \mathrm{O}\right)$ en methaan $\left(\mathrm{CH}_{4}\right)$ zijn broeikasgassen. Het broeikasgaseffect van $\mathrm{N}_{2} \mathrm{O}$ en $\mathrm{CH}_{4}$ is respectievelijk 298 en 25 keer sterker dan dat van $\mathrm{CO}_{2}$ per $\mathrm{kg}$. Op wereldschaal is circa $40 \%$ van de totale antropogene $\mathrm{NH}_{3}$ - en $\mathrm{N}_{2} \mathrm{O}$-emissies en bijna $10 \%$ van de antropogene $\mathrm{CH}_{4}$-emissies afkomstig van dierlijk mest. Het verlies van stikstof $(\mathrm{N})$ en fosfor $(\mathrm{P})$ uit mest leidt bovendien tot een vermindering van de bemestende waarde van mest.

De risico's van emissies van $\mathrm{NH}_{3}, \mathrm{CH}_{4}$ en $\mathrm{N}_{2} \mathrm{O}$ uit mest naar de lucht en van de uitspoeling van $\mathrm{N}$ en $\mathrm{P}$ uit mest naar grondwater en oppervlaktewater hangt af van de opslag en behandeling van mest in de gehele mestketen. De mestketen begint bij het voeren van de dieren en eindigt bij de toediening van de mest op het land.

Er zijn verschillende maatregelen en technieken beschikbaar om mest te bewerken en emissies uit mest te reduceren. De introductie van een maatregel in het begin van de mestketen kan effect hebben op de emissies in een later deel van de mestketen, en het kan de emissie van andere vervuilende stoffen veroorzaken. De effecten van en interacties tussen maatregelen op emissies uit mest in de mestketen zijn slechts in beperkte mate bekend. Bovendien zijn de gevolgen van combinaties van maatregelen en technieken op emissies nauwelijks onderzocht.

Het onderzoek, dat in dit proefschrift is beschreven, had tot doel (i) het inzicht te verbeteren in de effecten van emissiebeperkende maatregelen en mestbewerkingstechnieken op de emissies van $\mathrm{NH}_{3}, \mathrm{~N}_{2} \mathrm{O}$ en $\mathrm{CH}_{4}$ naar de lucht en op de resterende hoeveelheden $\mathrm{N}$ en $\mathrm{P}$ in de mest in de mestketen, en (ii) om de effecten te verkennen van combinaties van maatregelen en technieken om de emissies verder te verminderen en de resterende hoeveelheden $\mathrm{N}$ en $\mathrm{P}$ in de mest te verhogen. 
Het onderzoek maakte deel uit van het Marie Curie Trainings Programma "ReUseWaste" (Winning en gebruik van nutriënten, energie en organisch materiaal uit dierlijke mest). In totaal waren elf promovendi en twee postdocs betrokken bij dit project; er zijn diverse specifieke emissiebeperkende maatregelen en mestbewerkingstechnieken onderzocht en verbeterd. Het onderzoek beschreven in dit proefschrift richtte zich op de integrale analyse van mogelijke maatregelen op de emissies in de gehele mestketen en op de opschaling en de synthese van de onderzoeksresultaten uit ReUseWaste en de literatuur. Het proefschrift heeft 5 hoofdstukken met specifieke resultaten van het onderzoek, een algemene inleiding (hoofdstuk 1) en een algemene discussie (hoofdstuk 7).

In hoofdstuk 2 is een studie beschreven waarin verschillende methodes voor de berekening van de $\mathrm{N}$-excretie door vee werden beoordeeld. De stikstofexcretiefactor is gedefinieerd als de totale hoeveelheid $\mathrm{N}$ die gemiddeld per diersoort per jaar via de urine en feces wordt uitgescheiden. In de studie zijn de methoden en richtlijnen, die door de Nitraatrichtlijn, OECD/Eurostat, EMEP/EEA, IPCC en lidstaten worden voorgeschreven, geanalyseerd en met elkaar vergeleken. De resultaten tonen aan dat N-excretiefactoren voor melkvee, varkens, leghennen, vleeskuikens, schapen en geiten aanzienlijk verschilden tussen lidstaten, en ook binnen landen tussen verschillende rapportages ten behoeve van nitraat-, ammoniak- en klimaatbeleid. Een deel van deze verschillen worden veroorzaakt door verschillende in veerassen (grootte/gewicht van de dieren), productiviteit, en in voersamenstelling. Een ander deel van de verschillen in $\mathrm{N}$-excretiefactoren wordt veroorzaakt door verschillen in rekenmethoden en in de methode van aggregatie van diercategorieën. De methoden en gegevens die worden gebruikt door de lidstaten in de EU zijn vaak niet goed beschreven. Er is behoefte aan geharmoniseerde en goed gedocumenteerde rekenmethoden en procedures voor de vaststelling van $\mathrm{N}$-excretiefactoren. Uniforme methoden en procedures vormen de basis voor een nauwkeurige schatting van de productie van $\mathrm{N}$ in mest, van $\mathrm{N}$-balansen in de landbouw en de uitstoot van $\mathrm{NH}_{3}, \mathrm{~N}_{2} \mathrm{O}$ en $\mathrm{CH}_{4}$ uit mest in de EU.

Hoofdstuk 3 beschrijft een studie waarin een robuuste en uniform toepasbare methode is ontwikkeld om de N-excretie per diercategorie per jaar voor alle landen van de EU-27 te berekenen. Deze methode is gebaseerd op de energie- en eiwitbehoefte van de dieren en op statistische data en informatie over voersamenstelling, dieraantallen en productiviteit. In de EU-27 werd in 2010 in totaal $506 \mathrm{Tg}$ voer gebruikt $\left(1 \mathrm{Tg}=10^{12}=1\right.$ miljoen ton $)$. Melkkoeien gebruikten 29\%, jongvee en mestvee 34\%, varkens 17\%, kippen 9\%, schapen en geiten $8 \%$, en andere diercategorieën 3\% van het voerverbruik in de EU. Gras en andere ruwvoeders 


\section{Samenvatting}

werden voornamelijk gebruikt door melkkoeien (30 en 49\%, respectievelijk) en ander rundvee (55 en 44\%). Varkens gebruikten vooral voergranen (53\%). Eiwitrijke diervoeders (bijvoorbeeld sojameel) werden vooral door varkens (34\%) en kippen (24\%) gegeten. Er waren grote verschillen tussen de landen in diervoeding, voornamelijk veroorzaakt door de variaties tussen landen in voerbeschikbaarheid en in de productiviteit van de dieren. De berekende N-excretie door alle landbouwdieren bedroeg 9,7 Tg in EU-27 in 2010. De Nexcretie varieerde van $14 \mathrm{~kg} \mathrm{~N}^{-1}$ landbouwgrond in Bulgarije tot $291 \mathrm{~kg} \mathrm{~N}^{-1}$ in Nederland. De ontwikkelde methode maakt het mogelijk om N-excretiefactoren van landen te valideren en om verschillen tussen landen te duiden.

In hoofdstuk 4 wordt een studie beschreven waarin de effecten zijn geanalyseerd van $\mathrm{NH}_{3^{-}}$ emissie beperkende maatregelen op de emissies van $\mathrm{NH}_{3}, \mathrm{~N}_{2} \mathrm{O}$ en $\mathrm{CH}_{4}$ uit mest. De analyse werd uitgevoerd via een meta-analyse van gepubliceerde gegevens (afkomstig van 126 gepubliceerde studies). Ook zijn de effecten van alternatieve combinaties van emissiebeperkende maatregelen op $\mathrm{NH}_{3^{-}}, \mathrm{CH}_{4}$,- en $\mathrm{N}_{2} \mathrm{O}$-emissies in de mestketen geëvalueerd via scenario-analyses. De volgende maatregelen leidden tot een significante reductie van $\mathrm{NH}_{3}$-emissies i) het verlagen van het ruw-eiwitgehalte in het voer (emissiereductie 24-65\%, afhankelijk van de reductie in ruw-eiwitgehalte), ii) het aanzuren van dunne mest in de mestopslag (83\%), het afdekken van dunne mest in de opslag met stro (78\%) of met een zeil (98\%), iii) het verdichten en afdekken van vaste mest in de opslag (61\%), en iv) het emissiearm toedienen van mest op het land via een sleepvoet-machine (55\%), via het inwerken van de mest in de grond (70\%) of via injectie van de mest in de grond (80\%). Door het aanzuren van de mest daalt ook de $\mathrm{CH}_{4}$-emissie uit mest in opslag (met 87\%). Het bedekken van dunne mest met stro leidt tot een forse stijging van de $\mathrm{N}_{2} \mathrm{O}$-emissie (met een factor honderd). Ook mestinjectie leidt tot hogere $\mathrm{N}_{2} \mathrm{O}$-emissies (26-199\%). Bij opslag van vaste (stapelbare) mest leidt het verdichten van de mest (via het berijden met een zwaar voertuig) en het afdekken met een tentzeil gemiddeld tot een verlaging van $\mathrm{NH}_{3}$-emissies, maar nemen de $\mathrm{CH}_{4}$ - en $\mathrm{N}_{2} \mathrm{O}$-emissies toe. Het aantal waarnemingen is echter gering dat ten grondslag ligt aan de laatst genoemde bevindingen. Het verlagen van het eiwitgehalte van rantsoenen en het aanzuren van dunne mest zijn strategieën die alle emissies $\left(\mathrm{NH}_{3}, \mathrm{~N}_{2} \mathrm{O}\right.$ en $\left.\mathrm{CH}_{4}\right)$ in de mestketen verminderen. Verschillende andere strategieën beperken de emissies van een specifiek gas of emissiebron, maar hebben ongewenste neveneffecten elders in de mestketen. Door te kiezen voor een juiste combinaties van maatregelen op bedrijfsniveau kan de uitstoot van $\mathrm{NH}_{3}$ en broeikasgassen uit dierlijke mest tot een minimum worden beperkt. 
Hoofdstuk 5 beschrijft een integrale analyse van maatregelen om de $\mathrm{NH}_{3^{-}}, \mathrm{N}_{2} \mathrm{O}$ - en $\mathrm{CH}_{4^{-}}$ emissies uit de mestketens te verminderen op nationaal niveau in EU-27 voor 2010. Hierbij is gebruik gemaakt van een aangepaste versie van het model MITERRA-EUROPE. De effecten van 12 mestbehandelingstechnieken op de emissies van $\mathrm{NH}_{3}, \mathrm{~N}_{2} \mathrm{O}$ en $\mathrm{CH}_{4}$ en de resterende hoeveelheden $\mathrm{N}$ en $\mathrm{P}$ in de mest werden verkend door middel van scenario-analyses. De effecten van maatregelen werden berekend bij een uniforme implementatiegraad van $20 \%$ in alle landen. Deze implementatiegraad werd in 2015 voor enkele maatregelen gerealiseerd in landen die voorop lopen met mestbehandeling. Er is ook een onzekerheidsanalyse uitgevoerd. De totale $\mathrm{NH}_{3}$-emissie uit de mestketen in EU-27 in 2010 was $2.5 \mathrm{Tg} \mathrm{N}$ en de totale broeikasgasemissie was $86.9 \mathrm{Tg} \quad \mathrm{CO}_{2}$-equivalenten, met een relatieve onzekerheid (variatiecoëfficiënt) van respectievelijk $16 \%$ en $20 \%$. De behandeling van mest reduceerde de broeikasgasemissies van 0 tot $17 \%$ in 2010, afhankelijk van het land. De grootste reductie werd verkregen door mestvergisting (met name in Duitsland, Denemarken en Italië). De effecten van mestbehandeling op $\mathrm{NH}_{3}$-emissies waren klein in 2010. De scenario analyses laten zien dat aanzuren, thermisch drogen, verbranden en pyrolyse tot een reductie van zowel $\mathrm{NH}_{3}$-emissies (9-11\%) als broeikasgasemissies (11-18\%) leiden in de EU-27 (in vergelijking tot een referentie zonder mestbehandeling). Mestbehandeling via nitrificatie-denitrificatie reduceerde de $\mathrm{NH}_{3}$-emissies, maar verhoogde de broeikasgasemissies (omdat $\mathrm{N}_{2} \mathrm{O}$ emissie toeneemt bij deze techniek). Composteren had geen significant effect op de totale emissies van $\mathrm{NH}_{3}$ en broeikasgassen. Mestvergisting reduceerde de broeikasgasemissie met 19\%, maar had amper een effect op de totale $\mathrm{NH}_{3}$-emissie. De combinatie van mestvergisting en het aanzuren van mest resulteerde in een significante vermindering in zowel $\mathrm{NH}_{3}-$ als broeikasgasemissies. De hoeveelheid $\mathrm{N}$ in de mest die uiteindelijk wordt toegediend op het land (in \% van de N-excretie in de stal) in EU-27 neemt toe van gemiddeld 57\% in 2010 tot $61 \%$ bij het scenario 'aanzuren', maar neemt af tot $48 \%$ in het scenario 'mestverbranding' en tot $52 \%$ bij behandeling via nitrificatie-denitrificatie. Andere technieken, zoals het scheiden van mest in een dikke en dunne fractie, mestvergisting, drogen en composteren, hadden slechts een beperkt effect op de resterende hoeveelheid $\mathrm{N}$ in de mest. De hoeveelheid $\mathrm{P}$ die uiteindelijk via de mest op het land wordt toegediend (in \% van de P-excretie in de stal) is geschat op $98 \%$ in 2010; deze hoeveelheid werd niet significant beïnvloed door mestbehandeling.

Hoofdstuk 6 beschrijft de resultaten van een enquête onder verschillende groepen belanghebbenden en actoren op het gebied van mestbehandeling in vier landen met een hoge 


\section{Samenvatting}

veedichtheid (Denemarken, Italië, Nederland en Spanje). De enquête was gericht op vragen betreffende i) succes- en faalfactoren bij de toepassing van mestbehandeling in de praktijk, ii) technieken die de meeste perspectieven bieden voor toepassing in de praktijk en iii) bedrijfskarakteristieken en de schaalgrootte van mestbehandeling die de toepassing van mestbehandeling beïnvloeden. Regelgeving van overheden wordt gezien als de belangrijkste factor die mestbehandeling in de praktijk stimuleert in de vier landen $(70 \%$ van de respondenten). De grootste obstakels voor de toepassing van technieken zijn gerelateerd aan economische factoren; gebrek aan investeringskapitaal, hoge kosten voor mestbehandeling en een lange terugverdientijd (45-60\% van de respondenten). Er waren relatief weinig zorgen over transport, geluidsoverlast en gezondheidsrisico's bij mestbehandeling. Mestscheiding en mestvergisting bieden het meeste perspectief voor toepassing in alle vier landen. De perspectieven van andere technieken waren meer land-specifiek, zoals het aanzuren in Denemarken, composteren in Spanje en het drogen en omgekeerde osmose in Nederland. Deze verschillen worden veroorzaakt door verschillen tussen landen en regio's in veedichtheid en in sociale, economische, politieke en milieukundige factoren. Bedrijfskarakteristieken en de schaal van toepassing van mestbehandeling werden genoemd als de belangrijke factoren bij het kiezen van een bepaalde techniek.

De belangrijkste conclusies van dit proefschrift zijn:

- De hoeveelheden $\mathrm{N}$ en $\mathrm{P}$ in mest in EU-27 zijn vergelijkbaar met of groter dan de hoeveelheden $\mathrm{N}$ en $\mathrm{P}$ die via kunstmest worden gebruikt. Er is echter een grote ruimtelijke variatie in mestproductie binnen EU-27. Ook de omvang van de excretie van $\mathrm{N}$ en $\mathrm{P}$ per landbouwdier varieert sterk tussen landen. Dit wordt vooral veroorzaakt door verschillen in rantsoensamenstelling en productiviteit van de dieren. Voor een nauwkeurige bepaling van de emissies van stikstof en broeikasgassen op nationaal niveau is het noodzakelijk om de excreties van $\mathrm{N}$ en $\mathrm{P}$ nauwkeurig te berekenen op basis van landen-specifieke data, een algemeen toepasbare rekenmethode en een transparent protocol. Een deel van de huidige verschillen tussen landen in gerapporteerde excretiefactoren en emissies wordt veroorzaakt door verschillen in rekenmethoden en aggregatiemethoden.

- Combinaties van effective maatregelen in de mestketen zijn nodig en mogelijk om de bemestende waarde van mest te verhogen en om de emissies van $\mathrm{NH}_{3}$ en broeikasgassen uit dierlijke mest te verlagen. Het verlagen van het eiwitgehalte in rantsoenen tot aanbevolen niveaus is een effectieve maatregel om de emissies van $\mathrm{NH}_{3}$ 
en andere $\mathrm{N}$-verbindingen in alle delen van de mestketen te verminderen. Andere maatregelen leiden vaak tot vermindering van de emissie van een specifiek gas of van een specifieke emissiebron, maar hebben een risico op afwenteling naar emissies van andere gassen of veroorzaken een toename van de emissie elders in de mestketen. Een combinatie van het verlagen van het eiwitgehalte in het voer en het aanzuren van mest kunnen het risco op afwenteling van emissies sterk beperken.

- De implementatie van mestbehandeling in EU-landen is divers en in het algemeen nog beperkt. De effecten van mestbehandeling op $\mathrm{NH}_{3}$ - en broeikasgasemissies zijn daardoor relatief klein op EU-schaal. Een grotere implementatie van de mestbehandelingstechnieken, inclusief aanzuren, verbranden, thermisch drogen, en vooral een geoptimaliseerde combinatie van technieken kan significant bijdragen tot het realiseren van de beleidsdoelstellingen met betrekking tot de reductie van $\mathrm{NH}_{3}$ - en broeikasemissies in de EU.

- De implementatie van mestbehandelingstechnieken geeft mogelijkheden om de benutting van $\mathrm{N}$ en $\mathrm{P}$ uit mest voor bemesting te verbeteren, omdat er producten vrijkomen met een andere N/P-verhouding. Het toepassen van een geoptimaliseerde combinatie van technieken om $\mathrm{NH}_{3}$-emissie te reduceren, leidt er toe dat meer $\mathrm{N}$ in de mest resteert, waardoor minder kunstmest $\mathrm{N}$ nodig is. Sommige technieken leiden echter tot minder $\mathrm{N}$ en $\mathrm{P}$ in mest en/of verminderen de beschikbaarheid van $\mathrm{N}$ en $\mathrm{P}$ in de mest voor gewassen.

- De implementation van mestbehandelingstechnieken in de EU wordt indirect gestimuleerd door EU-milieurichtlijnen en wordt beperkt door economische barrières. Technieken moeten economisch attractief zijn om toegepast te kunnen worden. Mestvergisting biedt inkomsten uit de productie van bio-energie, maar is zonder subsidies momenteel nauwelijks attractief vanwege de huidige lage prijzen voor fossiele brandstoffen. Er zijn slimme strategieën nodig om de kennis over mestbehandeling met betrekking tot de economische, technische en milieukundige aspecten te verbeteren en te verspreiden onder de belanghebbenden. 


\section{Acknowledgements}

After four years of hard working, my $\mathrm{PhD}$ research journey has come to the end. I would like to express my gratitude to everyone who has helped me during this period.

Firstly, I would like to express my deepest gratitude to my promoter Prof. Oene Oenema, for his constant encouragement and guidance in the last four years. I are very grateful to you for offering me this great opportunity to carry out my $\mathrm{PhD}$ research in Wageningen. I still remember how excited I was when you selected me as the $\mathrm{PhD}$ candidate and offered me this PhD scholarship in June 2012. I deeply appreciate for your full support throughout all stages of my $\mathrm{PhD}$ study. I believe that my skills, competence and capability in research are largely improved, which is attributed to your professional supervision and critical commenting, especially in strengthening the scientific significance and the novelty of my studies. The hardworking spirit of yours indeed encouraged me to complete my $\mathrm{PhD}$ in time. I have also learned from you that it is important to deal with problems at positive attitude. I have to say that I am really proud of being your student.

Secondly, I would like to give special thanks to my co-promoter, Dr. Gerard L Velthof, for his unreserved supports to my study. You often joked that supervising me is an voluntary work (as you were not involved in the ReUseWaste project). In fact, you have been involved in every stage of my $\mathrm{PhD}$ study. Without your supervision, I cannot image how I can produce these high-quality papers and my thesis. I feel lucky to have you in my supervision team. Your advice and suggestions are extremely valuable to me all the time.

Also, I am very grateful to Prof. Wenqi Ma in Hebei Agricultural University. I thank you for introducing me to the field of agricultural science. I really appreciate your supervision and guidance during my MSc study, and your kindness of offering me an temporary position as your assistant for one year after my MSc study. All those years of training have built up my confidence to carry on the $\mathrm{PhD}$ study.

I would like to thank Dr. Jan Peter Lesschen and Igor G. Staritsky in Alterra for providing assistance in developing the MITERRA model and in the optimization and uncertainty analyses. Your quick and efficient responses to help me solve those modelling problems really saved me a lot of time. 
I am very grateful to Prof. Fusuo Zhang in China Agricultural University for his advice and encouragement, which are extremely valuable for my future career.

I would like to thank all fellows and senior researchers in the ReUseWaste Project. I thank you for the comments and suggestions on my research during the project meetings, and especially for your great contributions to conducting the stakeholder survey. I am very grateful to all project partners who have organized those field exclusions, from which I have learned a lot of things in practical farming that are hard to be gained from the literature and books. I want to thank all $\mathrm{PhD}$ and post doc fellows in the project for sharing their ideas and experiences when we were in the meetings and courses or on the trips. I have learned different culture from you, which broaden my horizons. I would like to express my sincere gratitude to the coordinator of the project Prof. Lars Stoumann Jensen in University of Copenhagen for leading such outstanding project and for your crucial comments on my work.

I want to thank all the colleagues from the soil quality group, Wageningen UR, for sharing your knowledge in the staff seminars, and your stories and experiences during the coffee break. Special thanks to Marnella van der Tol and Esther van den Brug, the secretaries of SOQ, for your help and practical suggestions all these years. Many thanks to Prof. Lijbert Brussaard and Prof. Rob NJ Comans for their support and encouragement during my $\mathrm{PhD}$ study.

A special word of thanks to Lin Ma. I thank you for introducing this $\mathrm{PhD}$ scholarship to me, so that I had the chance to study abroad. I also thank Qin Wei and Chunxu Song for the unreserved advice and consistent encouragement. The assistance from Jingmeng Wang, Qian Liu, Mengchu Guo in the editing of my thesis, and from Rima Porre in translating the summary of my thesis is greatly acknowledged. I want to say thanks to my lovely officemates: Karst Brolsma, Tatiana Rittl and Rima Porre. Because of you, there were many laughs in the office and I am very grateful to have you accompany. Many thanks to Tian Zeng, Guohua Li, Yang Yu, Mingtian Yao, Dan Yan, Feng zhu, Huchen Li, Peipei Yang, Zhaohai Bai, Sha Wei, Junqi Zhu, Fang Gou, Liansun Wu, Wenfeng Cong, Junfei Gu, Xia Liu, Xinxin Wang, Chidu Huang, Wei He, Hongming Zhang, Liping Weng and many other friends, for their accompaniment and great supports, which made my life in Wageningen an extraordinary journey!

In the end, I would like to express you deepest gratitude to my mother for her love, support and for believing in me. I want to thank my brother and everyone in my family for their full 
support to pursue my study abroad. In particular, I am sincerely grateful to my beloved wife Zhang Caifeng, for her continuous support, encouragement and love! I am very glad to have you in my life journey.

Yong Hou

Shijiazhuang 


\section{Publication list}

(in this thesis)

Hou, Y., Velthof, G.L., Oenema, O., 2015. Mitigation of ammonia, nitrous oxide and methane emissions from manure management chains: a meta-analysis and integrated assessment. Global Change Biology. 21, 1293-1312.

Hou, Y., Bai, Z., Lesschen, J.P., Staritsky, I.G., Sikirica, N., Ma, L., Velthof, G.L., Oenema, O., 2016. Feed use and nitrogen excretion of livestock in EU-27. Agriculture, Ecosystems and Environment. 218, 232-244.

Hou, Y., Velthof, G.L., Case, S.D.C., Oelofse, M., Grignani, C., Balsari, P., Zavattaro, L., Gioelli, F., Bernal, M.P., Fangueiro, D., Trindade, H., Jensen, L.S., Oenema, O., 2016. Stakeholder perceptions of manure treatment technologies in Denmark, Italy, the Netherlands and Spain. Journal of Cleaner Production. (In press)

Hou, Y., Velthof, G.L., Lesschen, J.P., Staritsky, I.G., Oenema, O., Nutrient recovery and emissions of ammonia, nitrous oxide and methane from animal manure in Europe: effects of manure treatment technologies. Environmental science \& technology. (Accepted subject to revision)

Velthof, G.L., Hou, Y., Oenema, O., 2015. Nitrogen excretion factors of livestock in the European Union: a review. Journal of the Science of Food and Agriculture. 95, 30043014.

(other peer-reviewed articles)

Hou, Y., Gao, Z.L., Heimann, L., Roelcke, M., Ma, W.Q, Nieder, R., 2012. Nitrogen balances of smallholder farms in major cropping systems in a peri-urban area of Beijing, China. Nutrient Cycling in Agroecosystems. 92, 347-361.

Hou, Y., Ma, L., Gao, Z.L., Wang, F.H., Sims, J.T., Ma, W.Q., Zhang, F.S., 2013. The Driving Forces for Nitrogen and Phosphorus Flows in the Food Chain of China, 1980 to 2010. Journal of Environmental Quality. 42, 962-971.

Hou, Y., Ma, L., Sárdi, K., Sisák, I., Ma, W.Q., 2015. Nitrogen flows in the food production chain of Hungary over the period 1961-2010. Nutrient Cycling in Agroecosystems. 102, $335-346$.

Heimann, L., Roelcke, M., Hou, Y., Ostermann, A., Ma, W.Q., Nieder, R., 2015. Nutrients and pollutants in agricultural soils in the peri-urban region of Beijing: Status and recommendations. Agriculture, Ecosystems and Environment. 209, 74-88. 


\section{Curriculum vitae}

Yong Hou was born on 09 October, 1985 in Lincheng County, Hebei Province, P.R. China. In 2003, he graduated from the Lincheng senior high school. After that, he studied in the major of Agricultural Resource and Environmental Science in the Department of Resource and Environmental Science, Hebei Agricultural University, China. After he completed the Bachelor degree in 2008, he continued his research as a master student in the field of nutrient and resource management, in the Plant Nutrition Group, Hebei Agricultural University. He successfully completed the Master of Science degree in Agronomy in 2011, with the master dissertation entitled 'Characteristics and regulatory approaches of nutrient flows in intensive crop-livestock production systems of the Peri-urban area of China', financially supported by the Sino-German project "Recycling of Organic Residues from Agricultural and Municipal Residues in China”. During the master period, he was supervised by Prof. Wenqi Ma in Hebei Agricultural University, and jointly by Dr. Marco Roelcke and Prof. Rolf Nieder in Technical University of Braunschweig, Germany. During Sep. 2011- Sep. 2012, he was employed as an research assistant in Hebei Agricultural University.

In September 2012, he became a $\mathrm{PhD}$ candidate in Soil Quality Group, Wageningen University, the Netherlands, and was awarded as a Marie Curie fellowship as part of the EUfunded project "ReUseWaste: Recovery and Use of Nutrients, Energy and Organic Matter from Animal Waste". He was supervised by Prof. Oene Oenema and Senior scientist Dr. Gerard L. Velthof in Wageningen University and Research. His $\mathrm{PhD}$ dissertation is entitled "Towards Improving the Manure Management Chain". His PhD research was funded by the People Programme (Marie Curie Actions) of the European Union's Seventh Framework Programme FP7/2007-2013/under REA grant agreement no 289887. 
With the training and education activities listed below the $\mathrm{PhD}$ candidate has complied with the requirements set by the C.T. de Wit Graduate School for Production Ecology and Resource Conservation (PE\&RC) which comprises of a minimum total of 32 ECTS (= 22 weeks of activities)

\section{Review of literature (6 ECTS)}

- Mitigation of ammonia, nitrous oxide and methane emissions from manure management chains: a meta-analysis and integrated

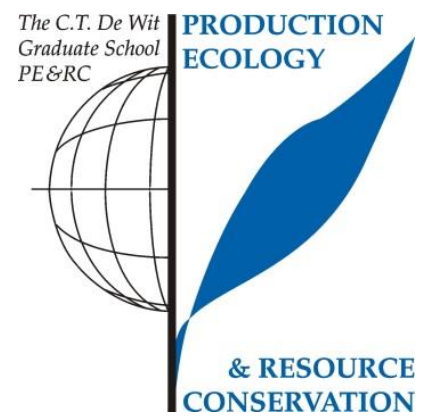
assessment

\section{Writing of project proposal (4.5 ECTS)}

- Integrated assessment of manure management chains in EU-27

\section{Post-graduate courses (3.8 ECTS)}

- Introduction to R for statistical analysis; PE\&RC (2013)

- Material flow analysis with STAN 2.5; TU Vienna (2013)

- Governmental policies dealing with nutrient management; Wageningen University (2013)

- $\quad$ Mata-analysis; PE\&RC (2014)

\section{Laboratory training and working visits (4.5 ECTS)}

- Data analysis and joint scientific paper writing; University of Copenhagen (2014)

\section{Invited review of (unpublished) journal manuscript (2 ECTS)}

- Agriculture, Ecosystems and Environment: band application of treated cattle slurry as an alternative to slurry injection: the need for an integrated evaluation (2015)

- Agriculture, Ecosystems and Environment: field evaluation combined with modelling analysis to study fertilizer and tillage as factors affecting $\mathrm{N}_{2} \mathrm{O}$ emissions: a case study in the Po valley, Northern Italy (2016)

\section{Competence strengthening / skills courses (6.9 ECTS)}

- PhD Introduction course; University of Copenhagen (2012)

- $\quad$ Project management workshop; University of Turin (2013)

- $\quad$ Scientific writing-A, fundamentals; Instituto Superior de Agronomia, University of Lisbon (2015)

- $\quad$ How to write grant proposals; University of Copenhagen (2015)

PE\&RC Annual meetings, seminars and the PE\&RC weekend (1.2 ECTS)

- $\quad$ PE\&RC Weekend (2012)

- $\quad$ PE\&RC Day (2013)

\section{Discussion groups / local seminars / other scientific meetings (5.2 ECTS)}

- $\quad$ Sustainable intensification of agricultural systems, Wageningen (2014-2015)

- Joint scientific workshop: innovative strategies to improve the recycling of energy, nutrients and organic matter from waste materials; Erfurt, Germany (2015)

- $\quad$ R-Users discussion group; Wageningen (2015-2016)

\section{International symposia, workshops and conferences (4.7 ECTS)}

- $\quad 15^{\text {th }}$ International conference: RAMIRAN; Versailles, France (2013)

- $\quad$ ManuResource conference; Bruges, Belgium (2013)

- $\quad 18^{\text {th }}$ Nitrogen workshop; Lisbon, Portugal (2014) 